\title{
FACING CHALEENGES
}

OF IDENTIFICATION

Investigating Identities of Buryats and Their Neighbor Peoples

Edited by

Kamil M.Wielecki

Ivan Peshkov

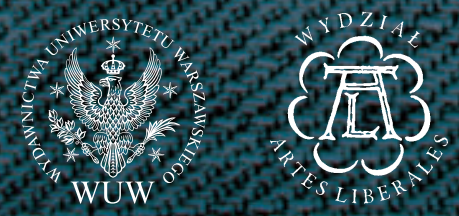




\section{Facing Challenges of Identification}




\section{LABORATORIUM INTERDYSCYPLINARNYCH BADAŃ ARTES LIBERALES (LIBAL)}

Wydział „Artes Liberales” Uniwersytetu Warszawskiego

\section{MONOGRAFIE LIBAL}

seria pod redakcją

JANA KIENIEWICZA

TOM III 
Faculty of "Artes Liberales"

University of Warsaw

\section{Facing Challenges of Identification}

\section{Investigating Identities of Buryats and Their Neighbor Peoples}

Edited by KAMIL M. WIELECKI IVAN PESHKOV
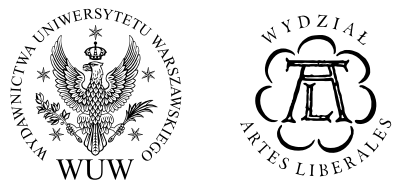

Warsaw

2020 
Reviewers

KATHRYN E. GRABER

ALEXEY MIKHALEV

Commissioning Editors

ANNA KĘDZIOREK

EWA WYSZYŃSKA

Proofreading and Editing

JAKUB OZIMEK

Cover Design

ZBIGNIEW KARASZEWSKI

Cover Photos of the Authors

AUTHORS' PRIVATE COLLECTIONS

Layout

IWONA MIŚKIEWICZ

Typesetting

DARIUSZ GÓRSKI

Published with financial support from the University of Warsaw.

Published with financial support from the Faculty of "Artes Liberales," University of Warsaw.

(C) Copyright by Wydawnictwa Uniwersytetu Warszawskiego, Warszawa 2020

(C) Copyright by Wydział "Artes Liberales" Uniwersytetu Warszawskiego, Warszawa 2020

Kamil M. Wielecki ORCID 0000-0003-0211-9884

Ivan Peshkov ORCID 0000-0001-8923-1937

ISBN 978-83-235-4725-9 (print) ISBN 978-83-235-4733-4 (pdf online)

ISBN 978-83-235-4741-9 (e-pub) ISBN 978-83-235-4749-5 (mobi)

Wydawnictwa Uniwersytetu Warszawskiego

00-838 Warszawa, ul. Prosta 69

E-mail: wuw@uw.edu.pl

Online bookstore: www.wuw.pl

1st Edition, Warsaw 2020

Print and binding POZKAL 


\section{CONTENTS}

Note on Transliteration $\ldots \ldots \ldots \ldots \ldots \ldots \ldots \ldots \ldots$

Kamil M. Wielecki, Ivan Peshkov

The Buryat Case and Beyond: An Introduction ..........

\section{I}

ETHNICITY AND NATION-BUILDING PROCESSES

Jan Kieniewicz

Identifying Local People: Colonial and Postcolonial Practices in Central Asia ....................... 23

Bair Nanzatov, Marina Sodnompilova

Buryat Ethnic Identity at Various Stages of Ethnic History . .

Marina Sodnompilova, Bair Nanzatov

Buryat Ethnic Self-Identification: New Trends and Aspects

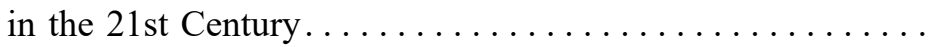

Ayur Zhanaev

Alternative History: Creation, Use and Interpretation of Buryat Genealogies $\ldots \ldots \ldots \ldots \ldots \ldots \ldots \ldots$

Kamil M. Wielecki

The Spirit That Permeates the Human Soul: Anthropology, National Epic, and Nation-Building in Kyrgyzstan ........ 


\section{CONTENTS}

\section{I}

\section{BUDDHIST IDENTITIES}

\section{Darima Amogolonova}

Buddhism and Orthodoxy in Buryatia: Religious Interaction in the Context of Russian Imperial Politics . . . . . . . . . . 135

\section{Bato Dondukov}

Electronic Petitions of Russian Buddhists: A Way of Consolidation or Estrangement? . . . . . . . . . . . . . . . . . . . . . 153

\section{I I}

\section{LANDSCAPE AND INDIGENIZATION}

Zbigniew Szmyt

Indigenization of Urban Landscape in Ulan-Ude

Darima Bajko

Ecological Discourse in the Cross-Border Region of the Selenga River in Russia and Mongolia . . . . . . . . . . . . . 207

Nikolai Baikalov

BAM and BAMers: Peculiarities of Identity Formation . . . . 227

Daria Burnasheva

Searching for a New Identity in a New Era: Emergence and Development of Sakha (Yakutia) as an Arctic Region ..... 255

Galina Dondukova

The Nomad's Star of Bair Dugarov as the Guiding Light of Post-Soviet Buryatia . . . . . . . . . . . . . . . . 279

About the Authors ..................... 301 


\section{NOTE ON TRANSLITERATION}

We use the Romanization style for Russian set by the American Library Association and the Library of Congress (ALA-LC). We adopted a simplified version of this style, omitting special characters (for instance, the letter $u$ is transliterated as $t s$, not $\widehat{t s}$, the Cyrillic letters $e, \ddot{e}$ and $\ni$ are all rendered as $e$, and the letters $\breve{u}$ and $u$ are both rendered as $i$ ).

However, we have made some exemptions from these rules for the sake of honoring existing conventions. Thus, firstly, we write Buryats and Buryatia instead of Buriats and Buriatia. The same goes for Yakuts and Yakutia (not Iakuts and Iakutia). Secondly, we respect the authors' choices regarding the Romanization of their names, whether or not they adhere to the ALA-LC style. 


\section{Kamil M. Wielecki}

ORCID 0000-0003-0211-9884

University of Warsaw

\section{Ivan Peshkov}

ORCID 0000-0001-8923-1937

Adam Mickiewicz University, Poznań

\section{THE BURYAT CASE AND BEYOND:}

AN INTRODUCTION

The presented volume comprises a follow-up endeavor to the conference "Facing the Challenge of Identification: New Approaches to Buryat Identities and Their Cross-Border Dynamics" that took place at the Faculty of "Artes Liberales," University of Warsaw, in June 2016. The conference was a joint venture of a few institutions and a number of people. Firstly, it resulted from two projects that were ongoing at the Faculty of "Artes Liberales" at that time: the international PhD Program "Searching for Identity: Global Challenges, Local Traditions," headed by Jan Kieniewicz, and the so-called East European School in the Humanities - a long-lasting program directed by Robert Sucharski, intended to foster cooperation between many academic institutions across Central and Eastern Europe. Secondly, the conference was instigated by a group of scholars from the Mongolia and Inner Asia Studies Unit, University of 
Cambridge, including its head, Caroline Humphrey. Finally, it was also organized by Ivan Peshkov from Adam Mickiewicz University in Poznań, who was behind the idea of the conference and, along with Jan Kieniewicz, Sayana Namsaraeva and Kamil M. Wielecki, formed the organizing committee of the event.

Even though the conference was a successful event, this volume aims at being something more than merely documentation of the conference proceedings. Granted, it consists of papers by some of the conference participants but we also invited other scholars who wished to contribute to the discussion of dynamically changing identities among Buryats and other nations of Eastern Siberia and Inner Asia. As a result, the volume includes a wide range of articles on various dimensions of identity across the region. Some of the papers present anthropological empirical research of particular groups, while other adopt a perspective of literary or ecological studies. The volume tries thus to link the diverse phenomena under investigation and different ways of research, and show them in a bigger context of historical and transnational processes. Lastly, it aims at bringing some theoretical contributions to studies of nations and peoples of broadly understood Inner Asia.

In the vein of the last remark, let us comment on the title of the volume. Combining challenges of identification with investigating identities may seem redundant. Moreover, for some time now, the very term identity has been subject to criticism and some scholars have even called for its abandonment (perhaps most notably Brubaker and Cooper 2000, but many others as well, e.g. Handler 1994 or Rouse 1995). Rogers Brubaker and 
Fredrick Cooper's critique of the term is twofold. ${ }^{1}$ Firstly, they point out, identity reifies social phenomena that are in fact social constructions. Secondly, it is used to describe diverse and only loosely connected phenomena. In other words, the second criticism questions the holistic pretensions of identity: a term which was intended to grasp the totality of human self-construction, in the practice of some researchers was reduced to merely one of its aspects. For instance, one's ethnic or religious identity was asserted to dominate over other aspects of one's self-perception and sense of belonging - be it gender, family, race or any other social qualities and roles of an individual. That is why Brubaker and Cooper prefer to use the notion of identification, since it avoids the trap of reification and refers to actual social processes. As for the notion of identity, they argue for breaking it into three different analytical clusters: identification and categorization; self-understanding and social location; and commonality, connectedness, and groupness (Brubaker and Cooper 2000: 14-21).

In our view, the term identification does address the aforementioned doubts to some extent. Indeed, it points more accurately to historically conditioned choices of individuals concerning their sense of community - choices that may seem to be made once for all, even though in reality they might change several times over one's lifespan. Yet, obviously enough, identification is still derivatively related to identity. More importantly, the affinity of the terms goes beyond merely linguistic one and is

${ }^{1}$ For the sake of concision, we follow Brian Donahoe with co-authors (Donahoe et al. 2009) in summarizing Brubaker and Cooper's argument as well as in responding to their critique of the term identity. 
rooted in ontological assumptions: perhaps there are no identifications without identities, seeing that identification as a process is only possible in relation to more or less fixed identities. Therefore, both terms seem indispensable.

Answering the first objection of Brubaker and Cooper, Brian Donahoe with co-authors (Donahoe et al. 2009) contend that researching social constructions - such as nations, races or genders - does not have to, and even should not, entail endorsing essentialist understandings. If you study nationalism, you have to take nation into account. However, even if some Buryats, Russians or Poles believe that their nations truly exist, you do not have to share their ontologies. As for the second objection, one can notice that identity is indeed a vague and usually too-broadly-applied term and thus a researcher should specify what they mean if they use it. At the same time, however, we must not overlook the fact that different dimensions of one's self-understanding and group connectedness usually overlap and consequently it might prove impossible to analytically separate them (cf. Donahoe et al. 2009: 5-7). We can add here that perhaps from its very beginning, anthropology - the study of the human being - was holistically oriented. A discipline which studies humans within the entirety of their environment, willingly or not has to use some umbrella concepts; this makes even research practice itself prone to overgeneralizations.

The challenge, therefore, lies in coining an operational definition of identity and identification. Speaking of collective identity, Donahoe et al. propose defining it as "a representation containing - or seeming to contain - a normative appeal to 
potential respondents and providing them with the means of understanding themselves, or being understood, as members of a larger category of persons or as participants in a larger assemblage." Identification, in turn, "refers most generally to the ways in which actors respond to or engage with collective identities" (Donahoe at al. 2009: 1-2). In other words, collective identities have to do with how people are and should be related to one another. Identifications or identification processes, in turn, are the ways in which people react to (accept, reject, reproduce, redefine, etc.) those normative appeals.

We follow these definitions, as they bring into dialogue several bipolar oppositions that have been hitched to identity discussions: primordial vs constructivist, individual vs collective, psychological vs social, structural vs dynamic, etc. We think that identity and identification - terms that in practice should get operationalized in every particular case - can still legitimately describe dynamic individual and social processes in different cultural settings. Moreover, such understanding of identity as always linked with identification renders its different dimensions and instances comparable.

The aim of the presented volume is to sketch an analytical framework for comparative analysis of diverse case studies of Buryats, an ethnic group living in a region divided by the borders of three states - Russia, China and Mongolia. The proposed perspective connects issues of border studies with the question of how ethnolinguistic identity is renegotiated through multi-level cultural politics. The volume refers to a long tradition of exploring Siberia and Mongolia in a broader Inner Asian 
context. Heightened interest in Inner Asia has led to research of local versions of biopolitics (Bernstein 2013), loyalty (Peshkov 2017), collaborative models of nationalism (Bulag 2010), and the difficult past of border areas (Quijada 2019). Also, we should have in mind the works that emphasize ontological pluralism in the politics of the body and the experience of public history. The link between challenges of identification and the border regime was presented in the volumes Frontier Encounters: Knowledge and Practice at the Russian, Chinese and Mongolian Border (Billé et al. 2012) and Northeast Asian Borders: History, Politics and Local Societies (Konagava and Shaglanova 2016). In this perspective, how the borders work in Inner Asia is directly related to the issues of language policy, religious diversity and different memory models.

Both theoretically and historically, borders have never been fixed categories, their conceptualizations as well as locations have varied depending on time and space. Border conceptualization constitutes an integral part of a society's identity, as it determines, to a considerable extent, processes and rituals of social integration. State versions of history are also strongly determined by processes of borders defense and legitimization.

One case in point are relationships between nomadic cultures and modern states, marked by a seeming contradiction between visions of threat from nomads created by official discourses and real practices of limiting the autonomy of nomadic or post-nomadic communities. Borderline location makes the situation even more dramatic, adding new fears connected with frontier disloyalty and the mutual influence, limited as it may 
be, between its nomads and their diasporas living outside the border. This connection of the official version of history with today's politics is not accidental, since it forms a perspective of the nomads' adaptation, legitimized as it is by official versions of the past. Such a perspective not only makes nomads assume a viewpoint on their history that is not their own, but also limits the agency of nomadic communities, suggesting to them that they should take on certain responsibilities in exchange for the gift of modernity and of - invented - tradition.

The content of the volume is divided into three thematic parts. The first one, "Ethnicity and Nation-Building Processes," opens with an article by Jan Kieniewicz, who adopts a bird's-eye view and addresses the colonial and postcolonial practices of naming local peoples and territories in Central Asia. In this perspective, identification and classification exerted by dominant Others remain an effective tool for blocking the path of the region's societies toward establishing a new identity that would not be a subordinated one. Despite these obstacles, many Inner Asian peoples have managed to establish themselves as nations.

The historical context is also important for Bair Nanzatov and Marina Sodnompilova, whose papers describe the development of Buryat ethnic identity. They analyze ethnic process in a longue durée perspective, from the ethnogenetic myths of the early Middle Ages up to the post-Soviet period, when Buryat tribal unions get reconstructed and undergo a self-organization that is not based on the principle of territoriality but draws on common ideologems and mythologems. The authors investigate those processes in their relation to state policy and historical discourses. 
The next paper of the section - by Ayur Zhanaev - is somewhat polemical to those of Nanzatov and Sodnompilova. Zhanaev argues that while Buryat genealogies may or may not constitute evidence of the general organization of society along kinship lines, they are certainly a powerful source for the creation of alternative social histories of the area. He focuses on Buryat genealogies as carriers of historical memory and of the ways of understanding the world, and, based on his fieldwork research, presents motives of creators and curators of local genealogies.

In the last paper of the section, Kamil M. Wielecki investigates the uses of the myth of Manas in post-Soviet Kyrgyzstan. Wielecki discusses disputes over the content of The Epic of Manas and analyzes the institutionalization of the cult of Manas. In this context, he describes the national policies of post-Soviet Kyrgyzstan's first president Askar Akaev and comments on the crucial role of native anthropology in the construction of national ideology in contemporary Kyrgyzstan.

The next part - "Buddhist Identities" - consists of two articles. In the first one, Darima Amogolonova examines interactions between Buddhism and Orthodoxy in the context of Russian imperial policies. She argues that the secular authorities faced a dilemma that consisted in the necessity to conduct Russification of the Empire's ethnic groups and simultaneously to strengthen the borders of the Empire in the East. Like other national minorities, the Buddhist population of the Russian Empire had to cope with practices of top-down institutionalization of their religious tradition (Lamaism) and of forced Christianization. 
The paper by Bato Dondukov explores, in turn, more current phenomena of the 2010s. He analyzes the encounters of the Russian Buddhist authorities with new, virtual models of integration. Dondukov argues that the popularization of such Internet tools as online petitions fosters a dialogue between different Buddhist communities throughout Russia, while distancing believers from religious institutions.

The third section - "Landscape and Indigenization" - opens with an article which ties in with the previous one, in as far as its author, Zbigniew Szmyt, also touches upon religious issues in today's Buryatia, namely the presence of shamanism. In his article about the indigenization of urban landscape in Ulan-Ude, he investigates the practices and discourses of the local politics of urban memory. His research on the post-colonial forms of urban place-making alerts us to the importance of holistic approaches towards new religious, spatial and economic activities.

The topics of landscape, indigenization and religion are continued also in the next paper, written by Darima Bajko. She argues that religious beliefs (Buddhism and shamanism), along with the attitudes to Nature that they imply, should be considered an important source of ecological ethics.

The articles of Nikolai Baikalov and Daria Burnasheva take us to the north of Siberia. Baikalov's article discusses the BAMers (the Baikal-Amur Mainline Railway builders) and their perception of the last Soviet modernization project as a big victory over nature and meaningful transformation of Siberian landscape. This "project of the century" had to do not only with infrastructure but also had a powerful potential for cultural 
formation. Burnasheva's article, in turn, focuses on practices and discourses of region-building in Sakha based on a global vision of Arctic identity. The spatial dimension has been a strong uniting factor for this multi-ethnic and multi-confessional area.

Lastly, Galina Dondukova's article discusses the famous poem The Nomad's Star by Bair Dugarov. She argues that the poem, in which Dugarov appeals to his contemporaries not to forget the nomadic principles of their ancestors, became a guiding light for Buryats in the critical time of the collapse of the Soviet Union. It comprised a powerful symbolic resource that urged Buryats to an ethnic revival.

In closing, we would like to express our gratitude to all of the Authors and everyone who contributed to the publication of this volume. We would also like to thank the University of Warsaw and the University's Faculty of "Artes Liberales" for funding this work.

All in all, the volume offers a broad array of approaches to the issues of identities and social identifications among Buryats and other peoples and nations of Siberia and Central and Inner Asia. We are happy to be able to present it to the Reader.

\section{WORKS CITED}

Billé, Franck, Gregory Delaplace, and Caroline Humphrey, eds. 2012. Frontier Encounters: Knowledge and Practices at the Russian, Chinese and Mongolian Border. Cambridge: Open Book Publisher.

Bernstein, Anya. 2013. Religious Bodies Politic: Rituals of Sovereignty in Buryat Buddhism. Chicago, London: University of Chicago Press 


\section{THE BURYAT CASE AND BEYOND: AN INTRODUCTION}

Brubaker, Rogers, and Frederick Cooper. 2000. "Beyond 'Identity." Theory and Society 29: 1-47.

Bulag, Uradyn E. 2010. Collaborative Nationalism: The Politics of Friendship on China's Mongolian Frontier. Lanham: Rowman \& Littlefield Publishers.

Donahoe, Brian, John Eidson, Dereje Feyissa, Veronika Fuest, Markus V. Hoehne, Boris Nieswand, Günther Schlee and Olaf Zenker. 2009. "The Formation and Mobilization of Collective Identities in Situations of Conflict and Integration." Max Planck Institute for Social Anthropology Working Papers 116: 1-47.

Handler, Richard. 1994. "Is 'Identity' a Useful Cross-Cultural Concept?” In Commemorations: The Politics of National Identity, edited by J. R. Gillis, 27-40. Princeton: Princeton University Press.

Konagaya, Yuki, and Olga Shaglanova, eds. 2016. Northeast Asian Borders: History, Politics and Local Societies (Special Issue). Senri Ethnological Studies 92.

Peshkov, Ivan. 2017. "In the 'Shadow of Frontier': Disloyalty at Russia-ChinaMongolia Border Zones.” History and Anthropology 28 (4): 429-44.

Quijada, Justine, B. 2019. Buddhists, Shamans, and Soviets: Rituals of History in PostSoviet Buryatia. Oxford: Oxford University Press.

Rouse, Roger. 1995. "Questions of Identity: Personhood and Collectivity in Transnational Migration to the United States." Critique of Anthropology 15 (4): 351-80. 


\section{I \\ ETHNICITY AND NATION-BUILDING PROCESSES}




\title{
Jan Kieniewicz \\ ORCID 0000-0002-3580-9112 \\ University of Warsaw
}

\section{IDENTIFYING LOCAL PEOPLE: COLONIAL AND POSTCOLONIAL PRACTICES IN CENTRAL ASIA*}

\begin{abstract}
The article addresses the influence on Central Asian reality exerted by naming and the practice of identifying the peoples inhabiting this area by dominant Others. I note that the identification of those human communities was always an act of aggression that led to establishing a relation between rulers and those subordinate to them. I submit that what joins various epochs in the history of the human communities of Central Asia is not imperialism but rather colonialism, and propose describing those processes by means of a systemic concept of colonialism.

Imperial practice in Central Asia was based on subordinating tribal communities and non-national states without deeper interference into their inner structures. Up until the 20th century the three great powers jockeyed above all to block one another. The change following the collapse of the USSR did not lead to the creation of regional independence. Rather, the national identities of the new states are a product of the modernization compelled by Soviet policies.

This especially concerns small communities that, always valuing their autonomy, did not strike observers-explorers as material for nations. The preponderance of the external point of view along with the influence of images arisen in the dominant surrounding (including that of science) maintain these

* This paper is an extensively modified version of a lecture of the same title, delivered during the workshop "Facing the Challenge of Identification: New Approaches to Buryat Identities and Their Cross-Border Dynamics" in Warsaw in June 2016.
\end{abstract}




\section{Jan Kieniewicz}

local communities in a state of backwardness. Identification and classification remain an effective tool for blocking their path toward establishing a new identity.

Keywords: identity, colonialism, Central Asia, Great Game, ethnicity, nation-building processes, postcolonial theory

Locals always have problems with their identity, but particularly so when they accept their identity as place-related localness. That does not mean they lack awareness of these problems; they can give expression of that - including when they describe themselves as locals because they want to or must hide something vis-à-vis the newcomer-observer (Latyszonek 1998). This happens independently of the distance dividing the observer from the observed. Newcomers, explorers and conquerors, colonizers and researchers, regardless of their intentions, have always had their ideas about locals. They observe and enquire, then form opinions which become embedded in the consciousness of people somewhere far away, people who will never meet these locals. It is then us, not those devoting direct attention to locals, who enshrine beliefs which compose our binding view of the world. By strength of domination, this view becomes universal, and circles back to the locals through the media and education. And the locals thereby forever remain, for example, Indians. Such is the case with the inhabitants of Central Asia, as they build their identity following models developed far away from them (Abashin 2015).

Let us pause over the term "Central Asia." This is required by the dualistic optics of the debate over the identity of Buryatia 
as conducted in Warsaw. I am convinced that this name fulfills a crucial role in positioning people in the postcolonial and at the same time postcommunist sphere (Łukawski 1996). Central Asia is a modern European concept that anchors a view of people living somewhere at a great distance. After all, the indeterminate geographical scope of Central Asia results from the premises accepted by the namers without the agreement of the named. At the same time, it is assumed that this is the neutral name and that its meaning is bestowed on it by its inhabitants and is only adopted by the outsiders after the inhabitants accept it. Science and politics consolidate this belief. An impression is made of things having always been this way.

What is more important, this belief is not at variance with our knowledge about the long history of these lands. Sogdiana, Bactria, or Gandhara were once the centers of the world and not the borderland between the Maurya and Achaemenid Empires. The steppe has always been the abode of people undertaking endless migration and expansion. Here the empires of Genghis Khan and Tamerlane emerged, here began the expansion that created the Mughal Empire - and it was in confrontation with the Steppe that imperial China and tsarist Russia developed (Khodarkovsky 2002; Gorshenina 2012). Between the Steppe, deserts and mountain ranges snaked the Silk Road, connecting all the great centers of civilization (Boulnois 1963; Hansen 2012). Between the 12th and the 15th centuries, this ecumene gave the final impulse to the first World-System (Abu-Lughod 1989). Mawarannahr, the ancient Transoxiana, created the core of this world when its peoples accepted Islam 
(Barthold 1963). Throughout the centuries, migrations, conquests, the building of cities and temples, the magnificence of art and science filled the space between the Caspian Sea and the Pacific Ocean, between Siberia and the Himalayas. 13th century Europe learned about this world thanks to Giovanni da Pian del Carpine, Benedict of Poland, William of Rubruck, and later Marco Polo. However, in later history, the ongoing confrontation of the Chinese, Persian, Russian, and Turkish empires performed a work of destruction (Saray 2003; Rieber 2014). One of the consequences was the conference of the name Central Asia. In lieu of the inhabitants' ethnic or state terms, a new division of the continent from the conquerors' perspective was accepted.

In this context, Central Asia is an element of ordering the world according to the dominant people's view (Gorshenina 2014). The term is ambiguous and altogether mutable, depending on the time to which it is related, but primarily on the political orientation of the author. Therefore, we have at least three variants of Central Asia (sometimes called "Inner Asia"): the British (Indian), Russian (Soviet), and Chinese one. Perhaps we should include a fourth one - namely, Turkish? The politics of the world powers, despite the changes which have come about in the last two or three centuries, remains in the spotlight. My interest, however, runs in a different direction: I wish to examine the influence that the expansion of the world powers had on the identity of the inhabitants of this great region. I wish to pay attention to the defense of identity characteristic of colonial times and to the identity-seeking processes connected with 
IDENTIFYING LOCAL PEOPLE: COLONIAL AND POSTCOLONIAL...

the postcolonial era. This quite arbitrary division will have to be verified.

Thus, Central or Inner Asia had a mutable image, depending on which imperial perspective was adopted. 19th century British governments included within Central Asia Ladakh, Lahaul and Spiti, Kumaon and Garhwal, Nepal and Sikkim, Bhutan and Assam. And, of course, the Chinese and Russian Turkestan. Defending the "Pearl of the Empire," Englishmen sent their agents-explorers to the "roof of the world," in order that they paralyze the encroachments of competitors, as far as that was possible. Dubbing these efforts a "great game" effectively shrouded the essence of events, ones which have had further continuations and consequences up until today (Hopkirk 1990). Above all, those agents-explorers gave their undertakings the hue of romantic adventure, as symbolized by the names Marc Aurel Stein and Sven Hedin.

Russians eagerly took advantage of the nomenclature that allowed them to include their expansion within the European convention. With their term "Inner Asia" they embraced the territories of the conquered Khanates (Khiva, Bukhara, Samarkand), but they also stretched the term to include Cashmere and Afghanistan. At the end of the 19th century, the land between the two world powers was relatively small, thinly inhabited, and without economic meaning. This was a sort of "middle land," the valleys of Alay and Hunza, Pamir, and the Tarim Basin. In the 19th century, England and Russia were unsure whether or not to include Tibet within the term. This was not a precaution resulting from a recognition of Chinese pretensions. 


\section{Jan Kieniewicz}

It was about gaining control without provoking conflict, a policy which was successful also in the 20th century (Laruelle 2008).

China has always had a different vision of its presence in relation to the world of nomads and all "non-Han" peoples (Perdue 2005). For the Qing dynasty, this part of the continent was to be not only a military buffer and a territory for fiscal exploitation, but also a region of potential colonization (Yasin 1984, 112). We can also claim that the Chinese concept of the world did not match the game conducted by the European powers. However, the expansion in the Qing era led to a clash of interests and intensified contact, primarily with regard to Russia's aspirations of expansion. Turkey was also present in this configuration; however, Turkey was itself an object of colonial domination by the European powers in the 19th century. In the 21 st century, Turkey has intensively taken advantage of the Turkic identification of some of Central Asian peoples. Finally, the entire region, from the Caucasus to Manchuria, became a space of very intense orientalization in the century of European domination.

These ideas did not fundamentally change after the Chinese and Russian revolutions, nor after the British withdrawal. Only superficially did communism, nationalism, and tiers-mondisme (Gallié 2012) create an opportunity for the peoples of former colonies to autonomously develop. In reality, slide they did into deepening dependence. The collapse of the Soviet Union created a new situation in which to lands occupied predominantly by Turkic and Tajik communities was added Kazakhstan, geographically resting in a different sphere. 
In the last quarter century, the Soviet Republics turned states Turkmenistan, Uzbekistan, Tajikistan, and Kyrgyzstan - have been subsumed under the term "Central Asia." Sometimes Kazakhstan, Mongolia, and Afghanistan are also included. Other countries on the borders of China or India were not. The context of today's state of affairs is the global information which has reached even the "roof of the world"; however, an equally strong influence is wielded by the radicalization of conflicts in the directly neighboring Muslim countries and by the "war on terrorism." The world powers are still conducting their game: today, it is not only the United States, but also Iran and Israel (Menashri 1998). Universities still actively take part in this game, too.

The colonial practice in the countries of the region relied on subordinating tribal communities or states lacking a national character, without deeper interference in their inner structures. Up until the 20th century, one could say that the three world powers acted primarily to block competitors in their pushes to absorb those lands within their sphere of influence. The changes that occurred after World War II, the subsequent decolonization, and the collapse of the USSR did of course entail abandoning old stereotypes, but those changes did not lead to regional self-reliance. The proposals to grant Central Asia a key role in humanity's further fate is yet another form of domination, perhaps ultimately Chinese (Roy 2007). What is crucial for me here, however, is not the geostrategic, but the human dimension.

This does not at all mean neglecting geostrategic factors. Mountain ranges remain in place, although their ecological 
reality began to undergo changes already a long time ago, as is revealed to us by the variability of the hydrographic system. In many cases, the conflict between the needs of agriculture and the interests of energy production has acquired a political character (Baker Brit 2016). Some of Central Asian states are affected by ecological disasters, and this compels dramatic decisions. Political conflicts, internal fighting, and the migrations related to them occur practically in all of these countries. And as for centuries the Silk Road favored the inhabitants of these lands, so now the consequences of the inevitable attempts to politically control them cannot be forgotten, either. For this reason, I focus my attention on Pamir, a relatively small land at the rub of the powers' interests. During the late 19th century, borders were delineated here, and over a century later they still divide a country that was exotic then, but has since become rather prosaic - or at least accessible to tourists. The identity of its inhabitants is still defined by ethnic and religious distinctions (Kraudzun 2012; Middleton 2016). At the same time, Pamir remains a part of Tajikistan, a post-Soviet state entity that builds its identity on a divergent ethnic and religious tradition (Bliss 2006).

What I wish to say about Central Asia should be situated in a broader context, not only colonial, but postcolonial as well. For it may seem that the oppression experienced by the people in this part of the world at the hands of the great political powers was incomparable with the fate of, for example, the peoples of Southern Asia that were directly subjected to colonial rule. In the 20 th century, they liberated themselves from European reign, 
only to become dependent from the new Asian countries. I have in mind not only the revolutions and civil wars accompanying this process. Part of the postcolonial peoples' heritage is, of course, namely the oppression experienced at the hands of the independent countries that arose in the decolonization process (Croissant and Trinn 2009). Vietnam, Cambodia, Myanmar, Cashmere, Mindanao, Sri Lanka, Timor are only some ready examples of repressive processes and genocide directed ultimately against the aspirations of various peoples to establish their own identity. This experience cannot be ignored when reflecting on Central Asia (Gunaratna 2002).

As I mentioned in the introduction, I propose to ponder the influence that is wielded by the dominant milieu on the smaller community's identity. I understand identity as the capacity of a social system to exist, but this also means the ability to be identified by Others (Mazur 1966; Kieniewicz 2005, 24). The milieu of a community is composed of different social systems, in this case primarily mediating the world powers' influence on the behavior of the dependent community. My thoughts concern the kind of practices of the dominant subject - first recognition, then naming - that can impact the identity processes of the subordinate subject, including when it is initially still trying to undertake independent behaviors but primarily when it gains the feeling of its ability to autonomously develop its own identity. These practices play an especially substantial role in the case of national communities, or communities seeking national identification - even despite anyone's opinion of the legitimacy of such ambitions. In the case discussed here, what 
has the greatest meaning is the belief in the national character of communities gaining state sovereignty subsequent to the collapse of the dominant organism - the Soviet Union (Fedorenko 2012). It is also important that this happened in consequence of an automatic, shared acceptance of naming conventions. The Soviet Republics, carved out arbitrarily and in circumstances of repression towards national aspirations, became recognized as state entities and ipso facto as nation states (Bingöl 2004; Serra Massansalvador 2010). This gave rise to many conflicts and civil wars. In the 1990s, the people of Pamir defended their ethnic and religious distinction from the dominant Tajiks. At the same time, they sought support in both Russian and Islamic traditions. The idea of Badakhshan as an independent political subject had no greater chance of realization than in 1895, when the English together with the Russians agreed the division between the emirs of Afghanistan and Bukhara. In my opinion, it is crucial to notice in this respect how deeply entangled identity aspirations are with opinions of outside provenance (Kurzman 1999).

This problem has interested me for a long time, especially in the circumstances created by borderlands (Kieniewicz 2011a; 2013) - and in particular civilizational borderlands, ones shaped by the encounters of diverse worlds (Kieniewicz 2001; 2014; 2017). My attention was attracted by the case of Poles, a national community with a colonial or hypothetically quasi-colonial past. Lately, I presented two crucial aspects of this matter - namely, the association of identity with the processes of transformation during pivotal moments in history, and the dynamic relation 
between defending and seeking identity (Kieniewicz 2015; 2016). These aspects reveal themselves particularly clearly in the relation between dominance and dependence: no matter how we try to present our community, whether real or imaginary, no matter how we try to understand it, we always have to take into account the influence of the environment - and the things we find out about ourselves from Others. Especially from those Others who gain influence on our behavior, or simply on our acceptance of perceptions created about us by the environment. Others of varying degree of closeness or foreignness, and therefore not only scholars, experts, investors, researchers, or tourists - but above all those who create our media image.

My thesis is that the identification of human communities by Others has always been an aggressive act, one leading to domination. Even when it was not related to conquest, in the literal sense of crossing borders and interfering directly in the social system of the dominated Others-Strangers (Kieniewicz 2005, $24 ; 2011 b)$. And even when the observer's intention was only registering all possible data, starting with the name - when the observer wanted to meet and examine, renouncing any thought of rule. I wish to present my thesis using the example of Central Asian peoples. Once upon a time, great world-changing expansions arose from these lands - however, in the last two centuries, they were on the margin of great imperial expansions. Today, in turn, we are again reminded that they are the heart of Eurasia (Hann 2016) .

In the era of colonial expansion, the identification of peoples began with the description of social and religious practices; 


\section{Jan Kieniewicz}

economic conditions were also of interest for fiscal reasons. The existing political affiliations and ruling systems were appraised in categories of usefulness in the planned conquests or in the projects for establishing control. The sharpest attention was devoted to the chances for exploiting resources. The knowledge acquired did not serve projects for reform. However, in the 20th century, ideological interpretations were introduced on a mass scale: nationalism and socialism became the categories organizing the former postcolonial powers. A result was the imposing of these categories on conquered peoples, whose attempts to regain sovereignty were efficiently blocked. This is obvious in the case of Soviet Russia - however, similar processes occurred in the lands which found themselves within China's borders after 1949. National identity ideas played a crucial role when bequeathed to locally predominate ethnic groups. Hence the inevitable conflicts (Włodek 2014, 50-52). Hence also the search for new identities in ideologies like Islamism.

It is a truism to opine that, when it comes to the identity of human communities, colonial and postcolonial practice do not differ in a fundamental way. I, however, go further to argue that the connection between different eras of the Central Asian communities' histories is not imperialism but colonialism (Kieniewicz 2008a). In so doing, I emphasize the consequences of expansion that are expressed in the cultural patterns of behavior determining development (Kieniewicz 1992b; 2009). This means that the endurance, and particularly the transformations, of these societies depend on their capabilities to autonomously build projects for the future. Such focus will also 
offer an opportunity to present the interpretation of colonialism as a fundamental element of identity-changing processes.

Learning about foreign people and observing their cultures, documenting their customs, and classifying forms of their social existence - this was an occupation of Europeans even before they called themselves Europeans. And not only in journeys outside the borders of their own world, but also in conquest indeed, in practically all phases of expansion: arrival, contact, realization, and consolidation (Kieniewicz 1986, ch. 2). The passion for describing the appearance and customs of the observed inhabitants spread also to European lands, at least to places where the interest in differences was accompanied by a sense of superiority (Kieniewicz 1984). Nor was this only a European attitude. Similar inclinations may be observed in the behaviors of representatives of other civilizations who visited European countries. If we agree that interest in others/strangers is universally human, then the specific European feature was not interest, but the tendency to introduce classification: examination through classifying which leads to ordering. This tendency, revealed with particular force by the beginning of colonial expansion and by the Enlightenment in the middle of the 18th century, went hand in hand with shaping the belief about the Europeans' civilizational mission (Wolff 1994; Osterhammel 2010, ch. 14). Even after they ran out of new lands to discover, a huge area was left for all kinds of studying and researching the human communities deemed worthy of the scholar's magnifying glass. This is how cultural anthropology was born, to which we all owe so much. Nonetheless, identifying people was never simply innocent 
entertainment or a noble scientific passion. Not even when the European observer consciously maintained the research criteria he had established, including respect for local nomenclature (Szymoszyn 2011).

Mapping the world also pertained to the process of discovery and was inseparable from subordinating the conquered (Wilford 1982). Thus, names were always imposed on peoples and states, and often the names given by explorers and conquerors have lasted up until today. Matters proceeded likewise towards territories with the introduction of names of mountain ranges or water basins. This ploy, which was chaotic in the early centuries of modern times, became in the hegemonic era of modernity a principle akin to the practice of labeling plants, animals, and minerals. The known world had to be described - and tamed. In the 19th century, this process underwent great acceleration, particularly in consequence of marking borders and establishing spheres of influence. Decolonization, in turn, meant not only restoring original names or creating new ones. It simultaneously meant maintaining colonial borders. The revindication of nomenclature was always inconsistent and did not violate the foundations of European knowledge about the Earth, the living world, and human communities. The petrification of borders, on the other hand, led to the exacerbation of identity conflicts.

We can thus say that all that modern science has established about Central Asia has in fact been a means in the creation of the Central Asian world. Beliefs that arose in the era of expansion and dominance continue to be the basis of the view passed on in the educational process and remain the basis of all 
communication processes. And so the people from lands once discovered, conquered, and subordinated, are still treated as locals, aborigines, or natives. How much does this global identification influence their identity? Indeed, their identity - just as its protection, just as quest for it - seems to me the crucial matter. Nonetheless, this matter concerns not only consciousness.

The indubitable fact of such identification of Central Asians, confirmed by various types of accounts from journeys, intelligence reports, and scientific descriptions from the 19th and 20th centuries, is interpreted as a consequence of colonial rule. However, we need also, or rather primarily, to pay attention to the role of these accounts in the processes of self-identification by subordinate peoples. To what degree did dominance become a causative factor even in national processes? How do today's identity processes influence the shaping of national identity?

Between 1885 and 1890, a Russian officer, Captain Bronisław Grąbczewski, the author of unusually interesting reports addressed to the authorities and science organizations in Russia, traveled through these lands, from Altai to Pamir (Grąbczewski 2010). During the same years, another traveler in this parts was Captain Francis Younghusband, an English officer and author of equally valuable reports (Younghusband 1896). These gentlemen were the same age, and when they met, they had much to talk about, although it is not entirely clear how much they wanted and managed to pass on to each other. What connected them was their participation in the Great Game, a certain affinity in the choices they made along life's path, but first of all the belief in the mission they were fulfilling toward 
those barbarous peoples. Identification was the first step to understanding the barbarians, after which would come the European rule that would lead to civilization. England is the obvious order succeeding chaos, says Captain Glenn to Staś, who is asking about the further fate of the lands engulfed by the Mahdist rebellion. ${ }^{1}$ Grabczewski was also convinced that Russian rule would be a blessing to the inhabitants of Pamir. A similar opinion was upheld by two more military men and researchers of these lands, Leon Barszczewski (Strojecki 2017) and Ole Olufsen (Olufsen 1904). One hundred years later, these routes were trodden by the Polish traveler Max Cegielski, who recounts the words of nostalgia of Pamir's people regarding Soviet times (Cegielski 2015, 258). And it is not only about their problems with identity when faced with the resilience of the Tajiks. The post-revolutionary era meant modernization (albeit compulsory), while the time of independence has proved to be one of uncertainty (Wielecki 2015).

If the influence of the world powers on identity processes in Central Asia can be defined as typical of the colonial era (that is, deepening dependence), then how to grasp these matters in a time when postcolonial narratives prevail? The difference seems insignificant. It expresses itself as an attempt at convincing those concerned that Central Asia again stands before a chance of taking the role of a world center in the civilizational process. This is supposed to be the result of rebuilding the

${ }^{1}$ Staś Tarkowski is the protagonist of Henryk Sienkiewicz's novel In Desert and Wilderness (originally published 1911). "The captain replied, 'And the whole edifice which the Mahdi reared will sooner or later tumble down.' 'And after that who will succeed?' 'England,' the captain answered” (Sienkiewicz 1912, 445). 
Silk Road, a sort of reversion to pre-Arab times, or to the era of Mongolian expansion. Considering the lack of interest on the part of the European Union, the suggestion of a BeijingIstanbul axis arises. The prospects of Turkestan as the heart of Eurasia are to be based on the enlivened trade along this very route. This is a geopolitical gambit which only minimally draws from the actual potential of the region (Okur 2014). In short, this is once again an amalgam of imperial ambitions and identity seeking.

It is, then, time to try a different interpretation. Identities in the lands of Central Asia were strongly influenced by colonialism. This influence was not strictly confined to colonial rule, though that also took place (Fierman 1991). Rather, I have in mind the condition of social systems whose transformations were performed under the pressure of external circumstances and needed examples coming from foreign civilizations, from dominant systems. I wish to say that in transformation processes dependence was based on using imposed models which were created by "developed" societies. Modernization processes, even if recognized as successful, usually meant embedding dependency. It is not all the same which models and from whom we accept. It sometimes happens that being dependent, societies seek models not from the ruling country, but from the experiences of leading countries (Kieniewicz 2008b). A lack of selfreliance can successively upend such efforts. This was the case of the societies of Central Asia, cornered from all directions by the territorial encroachments of world powers, but not described as colonies. Above all, the Russian rule was considered to be 
divergent in character to the British rule. This seems dubious to me. Recently, the concept of "internal colonialism" is an attempt to abandon the extraordinary treatment given to Russian, and especially Soviet, imperialism (Etkind 2011). Yet in my view, it does not explain the phenomenon of backwardness and the dependent progression of Central Asian societies. Therefore, I point out that processes set in motion by modernization's pressure, or simply by the lack of self-reliance in performing transformations, indeed engender colonialism in effect. I have in mind colonialism in the systemic sense of a series of behaviors that while in fact imposed, are internalized and incorporated into actions maintaining the system's existence.

I have found three basic relationships in Colonialism: "Submission", "Captivity" and "Utilization." Their common characteristic was the modification of all stimuli in favour of constrained development. In addition, a principle of "Subjection" should be distinguished. This last [one] seems to hold all the patterns of the "New Transformation" together and has clearly influenced the central steering system. All of these relationships and principles appeared in the socio-economic system in transition, and were not introduced from the outside. They were born, if that word can be used, in the process of confrontation between different systems of values. The confrontation itself was of course a consequence of the European expansion. The socio-economic systems were forced to open to the introduced information, and to accept relationships that went against their will and interests (Kieniewicz 1992a, 774).

The concepts presented above define the processes of "entering backwardness" and are crucial to the question about ways of getting out of it. In the specific case of Central Asia, we have to discern societies which, after the Russian Empire collapsed, gave rise to Soviet Republics, republics that subsequently gained (after the collapse of the USSR) the status of independent 
countries in the modern meaning of nation states. In these instances, the modern view consolidates the beliefs and mythology strengthening identities shaped in the age of Soviet domination. The position is divergent for those societies which did not gain political independence under either Russian or Soviet rule, nor have done so today, and are currently being pushed into the situation of "minorities." This especially affects small communities of the "land of the middle," who have always valued their independence, but who nevertheless did not appear to observers-explorers as nation material. The dominance of the external view, the influence of beliefs created by the environment (also the very distant environment) suspends these local communities in a condition of backwardness. Identification and classification, despite the new raiment in the world of global communication, remain an effective tool for blocking the ability of these societies to establish a new identity.

I will once again allow myself to self-quote, in order to show the conservative, hidebound character of the process:

1. Destabilized systems did not create their own appropriate answers to environmental challenges; especially, they did not turn into economic growth.

2. Their way of constrained development was the reason for the growing incapacity for proposed solutions. This was the case with Modernization. Enforced reproduction of the alien pattern converted economies of the Backward systems into dependent parts of the World-Economy.

3. The ecological disequilibrium was the reason for the growing internal tensions, especially in demographic, social and economic areas. But the system as a whole produced no successful technological, organizational or cultural project in response.

4. Original Structures were not able to offer independent solutions. The "block" in the Established Transformations changed an initially critical situation into tragedy (Kieniewicz 1992a, 773). 
The local communities "got back" their identities as part of a reproduced model, together with a "user manual." This is how the vicious circle of backwardness forms. The faith in the efficiency of modernization was increased by the assurance of its origin in scientific research. For these communities, revolutions, as attempts at modernization, were an external phenomenon, suggesting the ability of a leapfrog transition and of catching up with the paradigm. In Central Asian states, such revolutions involved annihilating old, precolonial structures and they influenced, in varying degrees, the ability of those societies to transform independently. The next stage after the collapse of the empire is the attempt to reject outside domination, but colonialism leaves behind a sort of acquiescence to the influence of empires, still expressed in identification of the once conquered groups. This is very clear in the aspirations of Central Asian countries to stabilize their nation states on an ethnic foundation, supported by centrally controlled mythological projects (Philips and James 2001). They are intended to draw in weaker ethnic groups into cooperation in building a common identity. This does not happen without obstacles, ones that include defense behaviors such as appealing to one's own myths - or simply to other projects.

External identification tends to be received in local communities as a factor supporting resistance to the dominant society's aspirations. Colonialism, regardless of its rhetoric, favors the belief about the ability to obtain the desired effect (access to civilization) through modernizing adaptation. The feeling of danger from the dominant society in the new country fosters the petrification of dependence. The defense of identity - in the 
form of fencing oneself off, rejecting the foreign, attachment to tradition - ceases to be recognized as effective. It gives way to independent attempts at modernization through adopting the convention of progress. The ineffectuality of these efforts in frameworks determined by the new states opens up a sphere for all sorts of postcolonial ploys. They are once again an effort taken up under the influence of the surrounding (external) social systems and according to an imposed predefined model.

\section{WORKS CITED}

Abashin, Sergey. 2015. "Soviet Central Asia on the Periphery." Kritika: Exploration in Russian and Eurasian History 6 (2): 359-74.

Abu-Lughod, Janet L. 1989. Before European Hegemony: The World System A.D. 12501350. New York: Oxford University Press.

Baker Brit, Elizabeth. 2016. "Irrigation in the Khorezm Oasis, Past and Present:

A Political Ecology Perspective." Journal of Political Ecology 23: 1-25.

Barthold, Vasily Vladimirovich. 1963. Ulugh-Beg. Vol. 2 of Four Studies on the History of Central Asia. Leiden: Brill.

Bingöl, Yilmaz. 2004. "Nationalism and Democracy in Post-Communist Central Asia." Asian Ethnicity 5 (1): 43-60.

Bliss, Frank. 2006. Social and Economic Changes in the Pamirs (Gorno-Badakhshan, Tajikistan). London: Routledge.

Boulnois, Luce. 1963. La route de soie. Paris: Arthaud.

Cegielski, Max. 2015. Wielki gracz: Ze Żmudzi na dach świata [The great player: From Žemaitija to the roof of the world]. Kraków: Karakter.

Croissant, Aurel, and Christophe Trinn. 2009. "Culture, Identity and Conflict in Asia and Southeast Asia." ASIEN 110: 13-43.

Etkind, Aleksander. 2011. Internal Colonization: Russia's Imperial Experience. Cambridge: Polity.

Fedorenko, Vladimir. 2012. "Central Asia: From Ethnic To Civic Nationalism.” Rethink Paper, March. Washington: Rethink Institute.

Fierman, William, ed. 1991. Soviet Central Asia: The Failed Transformation. Boulder: Westview Press.

Gallié, Martin. 2012. "Introduction - des analyses 'tiers-mondistes' aux 'postcolonial studies' - théories critiques du pouvoir et revendications politiques" [Introduction "tiers-mondistes" analyses in "postcolonial studies" - critical theories of power and political claims]. Revue québécoise de droit international Hors-série (novembre), 1-10. 


\section{Jan Kieniewicz}

Gorshenina, Svetlana. 2012. Asie centrale: L'invention des frontières et l'héritage russo-soviétique [Central Asia: The invention of frontiers and the Russian and Soviet heritage]. Paris: CNRS Éditions.

Gorshenina, Svetlana. 2014. L'invention de l'Asie centrale: Histoire du concept de la Tartarie à l'Eurasie [The invention of Central Asia: The history of a concept, from Tartary to Eurasia]. Paris: Librairie Droz.

Grąbczewski, Bronisław. 2010. Podróże po Azji Środkowej 1885-1890 [Travels in Central Asia 1885-1890]. Warszawa: PWN.

Gunaratna, Rohan. 2002. Inside Al Qaeda: Global Network of Terror. New York: Columbia University Press.

Hann, Chris. 2016. "A Concept of Eurasia.” Current Anthropology 57 (1): 1-27.

Hansen, Valerie. 2012. The Silk Road. Oxford: Oxford University Press.

Hopkirk, Peter. 1990. The Great Game: On Secret Service in High Asia. London: John Murray.

Kieniewicz, Jan. 1984. Drogi do Indii [Passages to India]. Warszawa: KAW.

Kieniewicz, Jan. 1986. Od ekspansji do dominacji: Próba teorii kolonializmu [From expansion to domination: An attempt at a theory of colonialism]. Warszawa: Czytelnik.

Kieniewicz, Jan. 1992a. "Periphery and Backwardness: An Essay in the Interpretation of Colonialism." In $17^{e}$ Congrès International des Sciences Historiques (1990). Vol. 2, 771-9. Madrid: Comité International des Sciences Historiques.

Kieniewicz, Jan. 1992b. “In the 'Heart of Darkness': An Attempt to Interpret Colonialism as a New Transformation of a Backward Social System.” Hemispheres: Studies on Cultures and Societies 7: 43-52.

Kieniewicz, Jan. 2001. "Borderlands as Spaces for the Encounter of Worlds." In Terra Marique: The Cultural Intercourse Between the European Center and Periphery in Modern Time, edited by J. Kieniewicz, 146-58. Warszawa: Ośrodek Badań nad Tradycją Antyczną.

Kieniewicz, Jan. 2005. "Borderlands and Civilizational Encounter." Memoria y Civilización 8: 21-49.

Kieniewicz, Jan. 2008a. "Kolonializm: Glosa do debaty" [Colonialism: A gloss to the debate]. In Debaty IBI AL. Vol. 1, 71-2. Warszawa: Instytut Badań Interdyscyplinarnych "Artes Liberales."

Kieniewicz, Jan. 2008b. "Polski los w Imperium Rosyjskim jako sytuacja kolonialna" [The Polish lot in the Russian Empire as a colonial situation]. In Ekspansja, kolonializm, cywilizacja, edited by J. Kieniewicz, 244-62. Warszawa: Instytut Badań Interdyscyplinarnych "Artes Liberales."

Kieniewicz, Jan. 2009. "Political Violence, Civilizational Oppression, and Colonialism." In Silent Intelligentsia: Study of Civilizational Oppression, edited by J. Kieniewicz, 20-58. Warszawa: Instytut Badań Interdyscyplinarnych “Artes Liberales."

Kieniewicz, Jan. 2011a. “Obstoiatel'stva dialoga na pogranich'e: Nekotorye rozmyshleniia" [Conditions of dialogue in the borderland: Some reflections]. In Tsivilizatsionnyi vybor i pogranich'e. Vol 4 of Debaty IBI, edited by J. Kieniewicz, 91-108. Warszawa: Instytut Badań Interdyscyplinarnych “Artes Liberales." 


\section{IDENTIFYING LOCAL PEOPLE: COLONIAL AND POSTCOLONIAL...}

Kieniewicz, Jan. 2011b. "Pogranichnye territorii i vstrecha tsivilizatsii" [Borderland territories and the meeting of civilizations]. Obshchestvo: Sreda: Razvitie: Nauchnoteoreticheskii Zhurnal 2 (19): 66-72; 3 (20): 45-52.

Kieniewicz, Jan. 2013. "Pogranich'ia: Pol'skoe, Evropeiskoe, Evro-aziatskoe...?" [The borderlands: Polish, European, Eurasian...?]. Obshchestvo: Sreda: Razvitie: Nauchno-teoreticheskii Zhurnal 2 (27): 82-7.

Kieniewicz, Jan. 2014. „Pogranicza i peryferie: O granicach cywilizacji europejskiej" [Borderlands and peripheries: On the frontiers of the European civilization]. In Cywilizacja europejska, różnorodności $i$ podziały, edited by M. Koźmiński. Vol. 3, 81-96. Kraków: Universitas.

Kieniewicz, Jan. 2015. "What Kind of Identity Are We Searching For?” In Syberia: Tradycja i modernizacja. Vol. 9 of Debaty Artes Liberales, edited by K. M. Wielecki, 145-58. Warszawa: Wydział "Artes Liberales."

Kieniewicz, Jan. 2016. "Poszukiwanie tożsamości w procesie transformacyjnym" [The search for identity in a transformation process]. Przegląd Humanistyczny 2: 29-39.

Kieniewicz, Jan. 2017. "Wartości polityczne Rzeczypospolitej Obojga Narodów a granice aksjologiczne cywilizacji europejskiej - kilka refleksji końcowych" [The political values of the Commonwealth of Both Nations and the axiological frontiers of the European civilization - some closing reflections]. In Wartości polityczne Rzeczypospolitej Obojga Narodów: Struktury aksjologiczne i granice cywilizacyjne, edited by A. Grześkowiak-Krwawicz, 291-308. Warszawa: Wydawnictwa Uniwersytetu Warszawskiego.

Khodarkovsky, Michael. 2002. Russia's Steppe Frontier: The Making of a Colonial Empire, 1500-1800. Bloomington: Indiana University Press.

Kraudzun, Tobias. 2012. "From the Pamir Frontier to International Borders: Exchange Relations of the Borderland Population." In Subverting Borders: Doing Research on Smuggling and Small-Scale Trade, edited by B. Bruns and J. Miggelbrink, 171-91, Wiesbaden: VS Verlag.

Kurzman, Charles. 1999. "Uzbekistan: The Invention of Nationalism in an Invented Nation." Critique 15 (Fall): 57-98.

Laruelle, Marlène. 2008. "Russia's Central Asia Policy and the Role of Russian Nationalism.” Silk Road Paper. Washington DC: Central Asia-Caucasus Institute \& Silk Road Studies Program.

Łatyszonek, Oleg. 1998. "Krajowość i 'zapadno-russizm': Tutejszość zideologizowana” [The Natives movement and the West-Ruthenianism: Localness ideologized]. In Krajowość - Tradycje zgody narodów w dobie nacjonalizmu: Materiaty $z$ międzynarodowej konferencji naukowej w Instytucie Historii UAM w Poznaniu (11-12 maja 1998), edited by J. Jurkiewicz, 35-9. Poznań: Wydawnictwo UAM. Łukawski, Zbigniew. 1996. Dzieje Azji Środkowej [A history of Central Asia]. Kraków: Nomos.

Mazur, Marian. 1966. Cybernetyczna teoria ukladów samodzielnych [The cybernetic theory of autonomous systems]. Warszawa: PWN.

Menashri, David, ed. 1998. Central Asia Meets the Middle East. London: Frank Cass. Middleton, Robert. 2016. "History of the Development of the Pamir Region of 


\section{Jan Kieniewicz}

Tajikistan (Gorno-Badakhshan)." In Mapping Transition in the Pamirs: With Case Studies on the Changing Human-Environmental Landscapes, edited by H. Kreutzmann and T. Watanabe, 245-65. Cham etc.: Springer. https://doi. org/10.1007/978-3-319-23198-3

Okur, Mehmet Akif. 2014. "Classical Texts of the Geopolitics and the "Heart of Euroasia." Journal of Turkish World Studies 14 (2): 73-104.

Olufsen, Ole. 1904. Through the Unknown Pamirs; The Second Danish Pamir Expedition, 1898-99. London: Wiliam Heinemann. http://digitalcommons.unomaha. edu/afghanuno/34

Osterhammel, Jürgen. 2010. Die Verwandlung der Welt: Eine Geschichte des 19. Jahrhundert [The transformation of the world: A history of the 19th century]. München: Verlag C. H. Beck.

Perdue, Peter C. 2005. China Marches West: The Qing Conquest of Central Euroasia. Cambridge, MA: Harvard University Press.

Phillips, Andrew, and Paul James. 2001. "National Identity Between Tradition and Reflexive Modernisation: The Contradictions of Central Asia." National Identities 3 (1): 23-35.

Rieber, Alfred J. 2014. The Struggle for the Eurasian Borderlands: From the Rise of Early Modern Empires to the End of the First World War. Cambridge: Cambridge University Press.

Roy, Oliver. 2007. The New Central Asia: Geopolitics and the Birth of Nations. New York: New York University Press.

Sienkiewicz, Henryk. 1912. In Desert and Wilderness, translated by Max A. Drezmal. Boston: Little, Brown, and Company.

Saray, Mehmet. 2003. The Russian, British, Chinese and Ottoman Rivalry in Turkestan: Four Studies on the History of Central Asia. Ankara: Turkish Historical Society.

Serra Massansalvador, Francesc. 2010. "The Process of Nation Building in Central Asia and its Relationship to Russia's Regional Influence.” Jean Monnet/Robert Schuman Paper Series 10 (5).

Strojecki, Igor. 2017. Utracony świat: Podróże Leona Barszczewskiego po XIX-wiecznej Azji Środkowej [A lost world: Leon Barszczewski's travels in 19th century Central Asia]. Gliwice: Helion.

Szymoszyn, Anna. 2011. “'Stronniczość' versus 'obiektywizm’: Refleksje na marginesie dyskusji o politycznym uwikłaniu w badaniach etnologicznych" ["Partisanship" versus "objectivism": Reflections on the margins of discussions about the political entanglement in ethnological research]. In Antropologia i polityka: Szkice z badań nad kulturowymi wymiarami władzy, edited by W. Dohnal and A. Posern-Zieliński, 274-8. Warszawa: Wydawnictwo Instytutu Etnologii PAN.

Wielecki, Kamil. 2015. Coping with Uncertainty: Petty Traders in Post-Soviet Russia. Frankfurt am Main: Peter Lang.

Wilford, John Noble. 1982. The Mapmakers: The Story of the Great Pioneers in Cartography from Antiquity to the Space Age. New York: Vintage Books.

Włodek, Ludwika. 2014. Wystarczy przejść przez rzeke [Just cross the river]. Kraków: 
Wydawnictwo Literackie.

Wolff, Larry. 1994. Inventing Eastern Europe: The Map of Civilization on the Mind of the Enlightenment. Stanford: Stanford University Press.

Yasin, Madhavi. 1984. British Paramountcy in Kashmir 1876-1894. New Delhi: Atlantic Publishers \& Distributors.

Younghusband, Francis. 1896. The Heart of a Continent: A Narrative of Travels in Manchuria, Across the Gobi Desert, Through the Himalayas, the Pamirs, and Chitral, 1884-1894. London: John Murray. 


\title{
Bair Nanzatov
}

ORCID 0000-0001-8012-2515

Institute for Mongolian, Buddhist and Tibetan Studies,

Siberian Branch, Russian Academy of Sciences

\section{Marina Sodnompilova}

ORCID 0000-0003-0741-0494

Institute for Mongolian, Buddhist and Tibetan Studies,

Siberian Branch, Russian Academy of Sciences

\section{BURYAT ETHNIC IDENTITY \\ AT VARIOUS STAGES OF ETHNIC HISTORY*}

\begin{abstract}
This article sets out to study the process of uniting the Buryat community and the relevance of different levels of ethnic identity as reflected in genealogical myths. Among important markers of the ethnic self-presentation of Buryats were mythical ancestors of the Buryat people (Bulagat, Ekhirit, Zonkhi, etc.). The emergence of these characters is closely connected with the history of the development of the Buryat people and reflects certain stages in the consolidation of ethnic groups into a united community that calls itself "the Buryats." The earliest of these stages (in the early Middle Ages) is reflected in the genealogical myth of Bulagat, Ekhirit and Khoridoi and their heavenly wives - swan maidens. In the 14th-17th centuries, the Baikal region saw a new wave of ethnogenesis, marked by consolidation of large tribes of
\end{abstract}

* This article is a revised translation of a Russian-language paper (Nanzatov and Sodnompilova 2016). 


\section{Bair Nanzatov, Marina Sodnompilova}

Bulagats, Ekhirits, Khori-Tumats and other ethnic groups into a single community opposed to the Mongols. During this period, the storylines of the main Buryat ethnogenetic myths were revitalized and new characters were added to the genealogy that represented different ethnic groups of the Buryats.

Keywords: Buryats, ethnic identity, genealogical myth, ethnic history, self-presentation

The post-Soviet period in the ethnic development of the Buryat people is marked by the mainstreaming of Buryat ethnic history. Any Buryat person who studies genealogy of his or her family - and the number of such people in the contemporary Buryat society is steadily growing - at some point inevitably faces the problem of the origin of Buryats. As conversations with many of those people suggest, genealogical myths are of a great importance for the reconstruction of genealogies. In virtually every case, mythical primal forefathers take their place of honor at the roots of the genealogical tree. And while the burbot and Bukha Noion are regarded as mythical characters and do not appear in real genealogies - Bulagat, Ekhirit, Tugalak (Mong. Toyloy) or Zonkhi (Mong. Jongki, Bur. Zongki) do generally lead Buryat genealogies, even if the middle links of these genealogies are often missing.

Mythical characters described as primal forefathers of the Buryat people have become important markers of ethnic selfpresentation of Buryats. Those include the chief characters, like Bukha Noion, Buriadai (Mong. Buriadai), Khoridoi (Mong. Qoridai), Asuikhan (Bur. Asuiqan), Khusuikhan (Bur. Qusuiqan), 
Ekhirit and Bulagat, and secondary ones, such as Toglok, Zonkhi, Ashibagat, among others. The emergence of these personages is closely connected with the history of development of the Buryat people, reflecting definite stages in the consolidation of ethnic groups into a single entity named "the Buryats." This article aims to study the making of the Buryats as an entity and the mainstreaming of various levels of ethnic identity, using genealogical myths as a case study.

The early medieval epoch was a period of blossoming Turkic states in Central Asia. In Cisbaikalia, it was marked by the emergence of a political union of Turkic and Mongolian tribes called Üč Qurïqan, or "Three Camps.” And it is in the Quriqan period (7th-8th century AD) that such tribes as Ekhirits and Bulagats emerged, forming the kernel of the ethnic entity that later became the Buryat people.

Integration of separate ethnic entities into a single community always requires establishing a mythical kinship, which is reflected in genealogical legends. The genealogical myth about Bulagat and Ekhirit is one of the main and oldest myths of the Buryats, reflecting an early period of the nation's making. The origin of Bulagat is derived from the mythical Buryat primal forefather Bukha Noion, whose image - widespread in the Turkic and Mongolian world - is closely associated with the cult of the bull. Bulagat became an adopted son of two old childless female shamans of Evenki origin. A little later the women managed to adopt another supernatural boy, Ekhirit, son of a burbot and a coastal crevice, who was of the same age as Bulagat (according to one version, he was Bulagat's 
twin brother). The indefinite image of Ekhirit's parents points to the archaic nature of the legend and, consequently, the fact that the Ekhirits are the most ancient settlers of Cisbaikalia (Pavlov 2002, 55). The fact that the main myth about Bukha Noion as a primal forefather includes only the eponym Bulagat allows one to assume that it was created by the Bulagats and was then expanded by the Ekhirits, who included in it their totem, the burbot (Skrynnikova 1997, 8).

The large Oirat tribes neighboring Bulagats and Ekhirits eventually left the Enisei-Baikal region and settled in the vast lands that later became known as Dzungaria. However, a part of them remained - the existence of the ethnonym Oliot (Bur. Ölöd) in the Buryat genealogical tradition points to the Oirat layer in Buryat ethnic history (Konovalov 2011). In Buryat versions, Oliot is known as Iliuder Turgen / Ulidei (Bur. Ilüder Türgen / Ülidei), a son of Bargu Bator (Bargudai), who in turn is the elder son of Buriadai. In the genealogical legend he serves as the justification for introducing into the general Buryat sphere such tribes as Segenut, Ikinat, Zungar (Mong. Jungar), Qurumshi (Mong. Qurumči, Bur. Qurumši), etc. as direct descendants of Iliuder Turgen / Ulidei.

The Bulagats' and Ekhirits' relations with the local Oirat tribes were rather circumstantial and forced, and therefore complicated. The legends tell of matrimonial ties of the Bulagats and Ekhirits with Oirats (Tsegenuts - Mong. Čegenüüd, Bur. Segeened - and Ikinats, Bur. Ikinad). According to a number of legends, one of the Bulagat forefathers, named Tugalak, son of Bulagat, was married to a girl from the Tsegenut tribe. 
One of Ekhirit's sons (Alagtai) was in his turn married to a Tsegenut girl named Abazai (Tugutov and Tugutov 1992, 179-81). This inclusion of the Tsegenut tribe (represented by women, newcoming brides) into the highest hierarchical cluster testifies to the antiquity of the ties between the Mongolianspeaking tribes of Cisbaikalia and, on an even deeper level, to the links between the Oirats and Buryats in the SayanCisbaikalia region in the early medieval period. Yet like the actual relations, the unions with Oirats that the legends describe are marred by various conflicts. Tugalak's wife dislikes her elderly husband and time and again tries to leave him, while Abazai is expelled by Alagtai's brothers after his death, and has to come back to live with her Tsegenut relatives (Baldaev 1970, 50). The outcome of these marital ties is the absorption by the Bulagats and Ekhirits of the descendants of the Oirats, seen as "alien" by the indigenous Bulagat clan groups. Descendants of Ekhirit's sons treat with hatred and contempt those descendant from Abazai, the Tsegenut bride. This was also the treatment received by descendants from Ashibagat, the youngest son of Tugalak and his young Tsegenut wife. This explains the secondary role of Ashibagat in the ethnic history of Buryats, which points to the time when the carriers of this ethnonym first appeared in the region. We assume that the Ashibagats appeared in Cisbaikalia much later than other Bulagat tribes.

Another large group, which joined the Bulagats even later than the Ashibagats, was a group of Turkic tribes of the Sayan area. Until the 19th century, they retained their local identity as 
Obogoni Olon. ${ }^{1}$ The tribal group is not related to the indigenous Bulagat tribes, and consequently, in the mythological version of kinship, they are not among direct descendants of Tugalak. That notwithstanding, the forefather of this tribal union, Obogon, in his own variant of the myth occupies the leading position in the genealogical tree of the Bulagats. This reflected not only the desire of the Obogoni Olon representatives to substantiate their genealogical kinship with other Bulagat tribes but also their urge to ascribe their forefather to the group of mythical tribal founders. Placing the founders of their tribes in higher positions in the hierarchy of forefathers is explained by the desire to be in one rank with the indigenous Bulagat tribes.

The late 12th and early 13th centuries saw an active formation of the Mongolian ethnicity, and the peoples of Transbaikalia were direct participants in this process. As Taras M. Mikhailov rightly states, in connection with the creation of the Mongolian state, voluntary involvement, struggle and neutrality all took place, and the connections between the steppe and forest Mongols had had long traditions (Mikhailov 1989, 87).

11th-14th-century authors called Baikal Siberia "the country of Bargujin Tokum (Mong. Baryujin töküm)" and added that it was declared a protected territory by the Mongols. By the time the Mongol Empire collapsed, Bargujin Tokum was a part of the Yuan state. However, after the ascent of the new Ming dynasty, the northern territories stayed out of control of Ming China. The ethnic history of this region is practically missing from written

\footnotetext{
${ }^{1}$ In our view, one of the main Yakut primal forefathers named Omogoi is associated with descendants of this group who went further north, down the Lena River.
} 
sources of that epoch right up to the arrival of Russians from the northwest and Manchus from the southeast in the early 17th century. Most contemporary scholars consider this period a "dark age" of history. With the disintegration of the Mongol Empire and formation of new polities on its Central Asian remnants, which leaned towards the main political center that was Southern Mongolia led by the Chakhar ruler Ligden Khan, the territory of Bargujin Tokum remained beyond the reach of the descendants of the Mongolian imperial house and acquired relative independence. In the 14 th and 15 th centuries, the isolated Cisbaikalia became a territory where a new round of ethnogenesis was taking place. In its result, the kernel of the Buryat ethnos was formed on the basis of the earlier ethnic entities, such as the Quriqan and the Bargu. They were joined by Mongolian tribes and groups who suffered losses in internecine wars in West and East Mongolia.

Until the time the Russians arrived, Transbaikalia remained within the zone of influence of Mongolian polities. The Mongolian domination in Transbaikalia is evidenced by a number of large archaeological monuments of the 14th and 15 th centuries (ancient Mongolian warrior burials, settlements, "townships"), Buryat legends and tales about Mongolian punitive expeditions and tribute collectors, as well as the account of Piotr A. Slovtsov, one of the first historians of Siberia, who wrote that the Transbaikalian country "was formerly under the rule of Genghis Khan and his successors" and "obeyed the two khans of the Khalkha system" until the mid-17th century (quoted after Mikhailov 1989, 92). 
The opinion, widespread among historians and regularly repeated in historiography, that prior to the Russian conquest of Siberia the Buryats were not a single entity is rather doubtful. The fact that a number of various tribal names appeared in the reports of the Russian officers about their reconnaissance missions in the Buryat lands is not reason enough to consider the Buryats a batch of scattered tribes. Despite contradictions, quarrels and armed conflicts, the single Buryat entity was already formed. Buryats' neighbors, the Kyrgyz and the tributepaying Tungus people, characterized this entity by the single ethnonym "Buryat / Pïrat" that entered the Russian language as "bratskie (literally, 'brotherly') people." This fact shows that the Ikires, Bulagat, Ashigabat and other tribes understood their unity, which since the ancient times was denoted by the ethnonym "Buriaad." In the legends of the Khori Buryats, it is highlighted that at the time of their return from Inner Mongolia to the northern shore of Lake Baikal and the Olkhon Island, the area was inhabited by "a nation called Buryats, who from ancient times lived along the northern and southern shores of Lake Baikal," and were descendants of Barga Bator's middle son named Buriaadai. In imitation, the Khori Buryats "began to be called by the Russian term - the Buryats of the eleven Khori clans" (Chimitdorzhiev and Vanchikova 1995, 7, 39).

The Mongolian language cemented this unity, too. The main substrate on which the Buryat ethnos formed consisted of large Mongolian-speaking tribes with Mongolian ethnonyms (like Shono and Abaga), who created the foundation for the Ekhirit, Bulagat and Khori ethnic groups. 
The single space of settlement, the territory of Bargujin Tokum, also testifies in favor of the existence of a relatively united entity under the ethnonym "Buryat." Cisbaikalia was inhabited by the Ikires/Ikirezh, Bulagat, Gotol, Ikinat - tribes mentioned in the reports of Russian conquistadors - but also by a great many other Buryat tribes, a part of whom was of ancient origin and had occupied these territories throughout many centuries. Among the oldest tribes were the Alagui and Khurkhuts (Bur. Qurqad). The large size of territories occupied by the Khurkhut, to name one example, is testified to by numerous toponyms like Kurkut / Kurkat, spread wide across Buryatia.

Many legends about the earlier period in the history of the region reflect the active and rather long-distance migrations of Buryat tribes - a "pre-Russian" stage of development of the Buryat entity, in which small and large groups, families, clans and tribes, regularly migrated in the territory of Bargujin Tokum, contributing to a gradual mixing of the population. The causes of migrations were diverse. One such cause was high population density. Migration could also be associated with cyclical economic activities, such as hunting and fishing. Settlement of new lands was accompanied by sacralization of space through transfer of sacral attributes of the clan religious cults, such as sacrificial altar stones, from the old settlement places. The legends that originated in this period thus describe mechanisms of sacralization of new territories by Buryats who had split from their clan and tribal social entities. If the territories where a group settled were occupied, the newcomers usually were incorporated into the religious 
systems of clan and tribal cults of the indigenous population. For instance, upon returning from Mongolia, the Ashibagats settled along the Chikoi River (Mong. Čöke, Bur. Süke) in Transbaikalia and worshipped the sacred Altai Khan Mountain, one of the five sacral centers of the Mongolian Khalkha clans.

This and other information about large-scale movements of Buryat tribes and clans in the entire territory of Bargujin Tokum is indicative of the existence of an entity within whose limits representatives of certain "bratskie" tribes were regarded as "ours" or "native."

Notably, the Khalkha Mongolian ethnos, which in the 15th and 16 th centuries was at its formation stage, already perceived the Mongolian entity living by Lake Baikal as "alien." This is confirmed by the existence of the ethnonym "Khariad" (Mong. Qariad from qari - "alien"), applied to the Buryats who escaped from the Balagan Steppes to Mongolia in the mid-17th century.

The Russian colonization of Siberia on the one hand and territorial expansion of the Qing Empire into northern Mongolian territories on the other became another very important stage in the ethnic history of Buryats. Foreign expansion triggered a mechanism of large-scale integration of Buryat ethnic groups. Their ranks were swelled by a large number of Mongolian ethnic groups fleeing from wars and unrest in the territory of Mongolian khanates and Dzungaria. Apart from these migration waves, the period saw the return to Buryatia of the Khori people, who managed to flee from Inner Mongolia amidst the Mongol-Manchu war.

The first encounters of Russians and Buryats were relatively peaceful. Later on, when the majority of Buryat chieftains began 
to perceive Russians as a threat, the consolidation of separate Buryat tribes into a single entity commenced. This process is clearly seen in Buryats uniting to besiege and demolish the first Russian forts. For example, in the destruction of the Bratsk Fort, the local Buryats were supported by squadrons from the shores of Lake Baikal. The Gotols unified with the Khongodors (Bur. Qongyōdor) in their struggle against Russians and attacked the Verkholenskyi (Upper Lena) Fort. The Khori returning from Mongolia joined the fight but after a number of clashes with the Russians eventually left the Cisbaikal Region for Transbaikalia.

It is probably in this period that a revitalization of the storyline of the main Buryat ethnogenetic myth takes place. Khoridoi is included into it as a younger son of Bargu Bator. His elder brothers are Iliuder and Buriadai. The revitalization of this myth with the return of the Khori after their centuries-long absence contains motifs which reflect both the archaic connections of the proto-Buryat tribes and the later Buryat ethnogenetic processes. The kinship of Khoridoi, Ekhirit and Bulagat in a single cluster of brothers, wherein Khoridoi is a younger brother, is found in the archaic variants of this myth. We argue that the transfer of the mythical character Khoridoi to another hierarchy, along Iliuder and Buriadai, highlights the stage of Buryat ethnogenesis when in Transbaikalia there already was an entity unified under the ethnonym "Buryat." Ekhirits and Bulagats became the kernel of this entity and the renewed myth prescribes the necessary inclusion of the returned Khori into the new entity's ranks. This variant of the myth corresponds to the colonization 
period in Cisbaikalia and is characterized by an awareness of the kinship between the Khori and Buryats, who both faced a new serious threat from the Russians invading from the west and Manchus from the east.

A complication and enrichment of the storyline of the Khoridoi myth is connected with another stage in the development of the Khori Buryat ethnic group, which took place within military alliances uniting representatives of the Bulagats and Ekhirits. At this stage, Khoridoi gets married to two earthly women, Sharaldai and Nagatai. ${ }^{2}$ The genealogical myth of the Khori in which Khoridoi's descendants are the sons of his earthly wives, whose names reflect the Bulagat and Ekhirit ethnonyms really existing in the upper streams of the Ida and Bayanzurkhen Rivers, is a product of a later stage in the demerger of the Khori alliance from the Bulagat and Ekhirit entity. In another variant of this late myth, presented by the 19th century Buryat chronicler Vandan Iumsunov, the first earthly wife of Khoridoi was Bargajan Goa, with whom he had daughter Alan Goa (Chimitdorzhiev and Vanchikova 1995, 37). Obviously, this myth is a response to the Khori Buryat claim to consanguinity with Genghis Khan, a claim that was very important for this ethnic group seeking its rightful place in the already formed Buryat society. The consanguinity of the Khori with the "Shaker of the Universe" is traced further back, up to Ligden Khan, whose daughter, according to the legend, was Balzhan Khatan, to whom the ancestors of the 11 Khori tribes were given as dowry.

${ }^{2}$ According to a more archaic variant, Khoridoi was married to a heavenly swan girl, which is indicative of a considerable Turkic segment within the Khori group 
In a 17 th century variant of the legend about 11 Khori tribes, in which the children of Khoridoi are born from the earthly wives Sharaldai and Nagatai, two genealogical subsets are missing. Most probably, these two missing subsets, whose forefathers' names remain unknown, reflect the openness of the Khori alliance to the incorporation of other tribes. However, the latter never happened, owing to a delegation of Khori Buryats to Tsar Peter the First, which resulted in the official registering of the Khori Buryats as 11 administrative units by the imperial authorities and in granting them lands in Transbaikalia for perpetual usufruct.

Aleksandr A. Elaev defines the initial period in the history of Russian colonization of the Buryat lands as a time of cultural and spiritual "self defense" and physical resistance (Elaev 2000, 59). A more precise term, in our view, would be a military democratic period. Marked by the integration of Buryat tribes for resistance against Russian colonization, this period played an important role in the consolidation of the Buryat ethnos

The Khongodors, who migrated from Mongolia in waves, and smaller ethnic entities settled on the right bank of the Angara - Tyrte (Bur. Terte), Shosholoks (Bur. Šošōloy) and Khoikho (Bur. Hoiho) - formed a large tribal alliance, which did not end up included into the mythological kinship of the Buryats.

The main group of Mongols - represented by the Uzons and Tsongols (both former subjects of Tushetu Khan), Khatagins (Mong. Qatayin), Atagans (Mong. Atayan, former subjects of Sain Khan) and Tabanguts - became a part of the Buryat ethnos later, when they returned to Transbaikalia (in 1665 and 1689) 
after a long period of absence. This happened already after the state boundary had been demarcated. The newcomers filed a request to the Tsar expressing their wish to become Russian subjects and received an official permission of the authorities, who were interested in the growth of taxable population at the border with the Qing Empire. The newly arrived tribes were settled in vacant lands.

Simultaneously with the acceptance of allegiance to the Russian Empire, the Mongolian tribes under the Russian rule acquired the ethnonym "Buryat," following an implicit rule observed in the relations between the Russian and the Qing Empires, whereby the Russian Mongolian-speaking population was called the Buryats, while the subjects of the Manchu Emperor were known as Mongols. ${ }^{3}$ Border guards of the two empires referred to this division while investigating border conflicts and determining the allegiance of refugees, who, in accordance with their self-definition, were either turned back or accepted.

Thus, with the completion of Siberia's incorporation into the Russian Empire, the ethnonym "Buryat" was assigned to all Mongolian-speaking ethnic groups of Southeast Siberia.

\footnotetext{
${ }^{3}$ In official documents, some Manchu subjects, such as the Dagurs and Solons, were referred to as the "Tungus of the Manchurian tribe." That is why in Russian historiography, they are frequently mistaken for the Evenks and Tungus.
} 


\section{BURYAT ETHNIC IDENTITY AT VARIOUS STAGES...}

\section{WORKS CITED}

Baldaev, Sergei P. 1970. Rodoslovnye predaniia i legendy buriat [Genealogical tales and legends of the Buryat]. Vol. 1. Ulan-Ude: Buriatskoe knizhnoe izdatel'stvo.

Chimitdorzhiev, Shirap B., and Tsymzhit P. Vanchikova, eds. 1995. Buriatskie letopisi [Buryat chronicles]. Kurumkan: Kurumkanskaia tipografiia.

Elaev, Aleksandr A. 2000. Buriatskii narod: Stanovlenie, razvitie, samoopredelenie [The Buryat people: Formation, development, self-determination]. Moskva: RAGS.

Konovalov, Prokopii B. 2011. "Ob oiratsko-buriatskoi etnoistoricheskoi obshchnosti: Istoriko-etnograficheskoe issledovanie" [On the Oirat-Buryat historical communality: A historical-archaeological study]. Vestnik BNTS SO RAN 2: 20-32.

Mikhailov, Taras M. 1989. “Iugo-Vostochnaia Sibir' v otnosheniiakh s Tsentralnoi Aziei v XIII-XVII vv." [Southeast Siberia's relations with Central Asia in 13th-17th centuries]. In Etnokul'turnye protsessy v Iugo-Vostochnoi Sibiri v srednie veka, edited by T. M. Mikhailov, 85-98. Novosibirsk: Nauka.

Nanzatov, Bair Z. and Marina M. Sodnompilova. 2016. "Etnicheskaia identichnost' buriat i istoricheskie mify v kontekste etnogeneza" [Ethnic identity of the Buryats and historical myths in the context of ethnogenesis]. Vestnik Vostochno-Sibirskoi gosudarstvennoi akademii kul'tury i iskusstv 2 (11): 5-12.

Pavlov, Evgenii V. 2002. "Variativnost' uranicheskogo panteona zapadnykh buriat i etnicheskaia istoriia Predbaikal'ia" [Variability of the Uranian pantheon of Western Buryats and the ethnic history of the Cisbaikal Region]. In Etnicheskaia kul'tura: Istoriia i sovremennost', edited by T. D. Skrynnikova, 32-62. Moskva, Ulan-Ude: VSGAKI.

Skrynnikova, Tat'iana D. 1997. "Izuchenie traditsionnoi kul'tury buriat: Novyi podkhod" [Studying the Buryat traditional culture: A new approach]. Mongolovednye issledovaniia 2: 3-19.

Tugutov, Iosif E., and Aleksei I. Tugutov, eds. 1992. Nebesnaia deva lebed': Buriatskie skazki, predaniia i legendy [Heavenly swan girl: Buryat fables, tales and legends]. Irkutsk: Vostochno-sibirskoe knizhnoe izdatel'stvo. 


\title{
Marina Sodnompilova
}

ORCID 0000-0003-0741-0494

Institute for Mongolian, Buddhist and Tibetan Studies,

Siberian Branch, Russian Academy of Sciences

\section{Bair Nanzatov}

ORCID 0000-0001-8012-2515

Institute for Mongolian, Buddhist and Tibetan Studies,

Siberian Branch, Russian Academy of Sciences

\section{BURYAT ETHNIC \\ SELF-IDENTIFICATION: NEW TRENDS AND ASPECTS IN THE 21ST CENTURY*}

\begin{abstract}
The post-Soviet period in the history of ethnic development of the Buryat people is marked by a mobilization of ethnic identity and ethnoterritorial self-organization. At present, communities based on the territorial principle are losing their importance. Tribal unions of Buryats have become an alternative, and their reconstruction has become an urgent task of modernity. Today, the Buryats of the Khongodor and Khori tribes follow this path of self-organization. The idea has also won support from other groups, like the Bulagats and Ekhirits. In the context of this process, ethnic ideologems and mythologems (the mythical ancestors of the Buryats, epic heroes) serve as mobilization symbols of national cultural revival.
\end{abstract}

Keywords: territoriality, genealogy, identity, elites, tribalism

* This study was funded by Ministry of Education and Science of the Russian Federation, Project No. XII.191.1.1. "The Transboundary Spaces of Russia, Mongolia and China: History, Culture, Contemporary Society,” State Reg. No. AAAA-A17-117021310269-9. 
The post-Soviet period in the ethnic development of the Buryat people has been characterized by a mobilization of ethnic identity and wide-ranging ethnic self-organization activities that are mainly marked by ideological/political coloring. ${ }^{1}$ In other words, by a national revival. This revival has been expressed in the struggle to preserve the Buryat language and in pursuit to preserve and develop traditional culture. Ideas were voiced to restore the 1937 borders of Buryatia (the BuryatMongol Autonomous Soviet Socialist Republic) (Elaev 2000). Organizations were created on an ethnic basis which were supposed to solve the problems of the national revival of the Buryat people (most notably the $\mathrm{VARK}^{2}$ ). One of the first organizations were the Buryat communities (zemliachestvo), called forth to unite the Buryat migrants according to the territorial principle - the Bokhan Community (Bokhanskoe zemliachestvo), the Ekhirit-Bulagat ${ }^{3}$ Community, etc. Currently, such communities are losing their significance. Ethnic communality, which is one of the dominant ideas of Buryat ethnicity (Elaeva 2005, 209), at the turn of the 21 st century underwent a change from the territorial-administrative principle, which was inherited from the Soviet era, to that based on clans and then tribes. Tribal unions of the Buryats have emerged as an alternative to existing groups, and their reconstruction has become an urgent task in the

\footnotetext{
${ }^{1}$ In general, the Buryat discourse in the period of "eruption of ethnicity" (late 1980s-early 1990s) was characterized by the inseparability of political and cultural aspects (Amogolonova 2008, 46).

${ }^{2}$ VARK - Vseburiatskaia assotsiatsiia razvitiia kul'tury (All-Buryat Association for the Development of Culture).

${ }^{3}$ According to Buryat mythology, the tribes of the Bulagat and Ekhirit descend from the legendary ancestors, the twin brothers Bulagat and Ekhirit.
} 
contemporary period. In the context of the idea of restoring tribal unions, ethnic mythologems (mythical ancestors of the Buryats, epic heroes, mythical motifs) have become the ideological base of national and cultural revival. One of the authors of this article (M. Sodnampilova) is a witness, and sometimes a participant in the search for new ways of ethnic self-organization of the Buryats in the 21 st century. This study aims to reflect on the ethnic processes that characterize the modern Buryat society drawing on the principles and methods of social constructivism.

The idea to move to clan organization is rooted in the Buryat past. Turning to the history of the formation of Buryat communities, it should be noted that the Buryat society was based precisely on tribal unions, ${ }^{4}$ which included clan groups (patronymia) descending from one ancestor (and disintegrating as soon as the number of generations of his descendants united in it exceeded seven). The "smaller ethnic communities" that were the tribal unions in different historical periods could grow to become territorial-administrative formations and up until the time when the Buryats entered the Russian Empire, it was on such tribal unions and the territories of their settlement that the Buryat administrative-territorial organization was based. Later the tribal principle of these formations was lost but the Buryats' awareness of their belonging to a particular clan and tribe has remained relevant all the while.

\footnotetext{
${ }^{4}$ Multiple works have been devoted to tribal unions in the past. Authors who have written about it include: Sergei P. Baldaev (1970), Georgii N. Rumiantsev (1969), Tsybikzhap B. Tsydendambaev (1972), and other contemporary scholars.
} 
As we have mentioned, the modern idea of uniting on a tribe basis was born in the context of a gradual decay of the Buryats' interest in communities based on the clan and regional (zemliachestvo) principles, an interest which nevertheless lasted for a rather long time and will possibly remain relevant for a certain part of the Buryat population. There was, however, a need especially among the national elites - for fresh ideas that could unite people and move societies beyond the clan groups to the level of bigger associations. In the context of this search for a unifying principle, the idea of recreating large tribal unions was adopted, which began to be realized with the emergence of the Uulyn Uladay Uulzalga (Mountain People Assembly) movement of the Khongodor Buryats, at first centered around the organizers of the eponymous cyclical festival, the first edition of which was held in February 1991 (Bartaeva 2013).

In 2015, the Khori-Buryats, too, supported the idea of a tribal movement. Once again, it started with the idea to organize a common tribal festival. The idea was supported by many representatives of the Khori tribe, including financially: the two thousand tickets sold out very quickly (Ochirov 2016). In early 2016, the Khori-Buryats Community ${ }^{5}$ officially announced a joint celebration of the Sagaalgan festival (associated with the Ancient Mongolian New Year) by all the Khori-Buryats and thus proposed a new format for communication. The tradition of the White Moon (White Month) meeting and celebration of

${ }^{5}$ The Khori-Buryats are a tribe of 11 Khori clans, who settled predominantly on the territory of Khori, Bichura, Kizhinga, Eravna, Aga and Khilok Regions. The Khori-Buryat Community (zemliachestvo) was established in the Soviet period. 
the ancient folk festival Sagaalgan was revived in 1990 as an official holiday in the Republic of Buryatia. Beginning from the first official celebration of Sagaalgan, in addition to the Buryatia-wide festive event, all the Buryat regional communities of Ulan-Ude held their own separate "regional" festivals. For example, the Khori, Kizhinga, Bichura, Selenga, Alar', Aga and other country fellowships held their Sagaalgan events in the Buryat Drama Theater during the entire White Month.

In 2016, this tradition was changed. For the first time in the new history of the Sagaalgan celebration, a common celebration gathered Khori-Buryats from all the regions of ethnic Buryatia: Khorinskii, Kizhinginskii, Eravninskii, Zaigraevskii, Bichurskii, Mukhorshibirskii Regions of Buryatia proper, ${ }^{7}$ three regions of the Aginskii (Aga) Buryat District, a number of regions of the Zabaikal'skii Krai (Aginskii, Duldurginskii, Mogoituiskii, Khilokskii, Chitinskii, and Petrovsk-Zabaikal'skii) as well as Khori-Buryats from Shenekhen in Inner Mongolia (China) and from Mongolia. The idea to hold such an event belongs to the president of the Aga Community Bato Ochirov, who believes that the Khori-Buryats have long felt the desire to unite into "a single format" regardless of the geography of their settlement. He thinks that this is a necessity because "present-day Buryats as a nation are in an absolutely demoralized state" and this is primarily due to the loss of "points of reference in terms

\footnotetext{
${ }^{6}$ The Buryat regions of the Irkutskaia Oblast and Zabaikal'skii Krai take part in this holiday, too.

${ }^{7}$ Khori Region is not the only Khori tribal territory. The Khorinskii Region which existed in the beginning of the Soviet period later lost some territories that were separated from it to become Kizhinginskii, Eravninskii, Bichurskii, Mukhor-Shibirskii and Zaigraevskii Regions.
} 
of culture and values (kul'turno-tsennostnye orientiry)." Bato Ochirov sees the reason for this state of the Buryats in the fact that the Buryat people formed from "associations of Mongolian ethnic groups with different cultural values. Accordingly, when national policy was being established in Buryatia, our society split ... [and it all] stopped" (Ochirov and Ian 2016). According to Bato Ochirov, a "dissociation" in favor of the tribal principle is necessary to prevent the possible death of the Buryat nation. The tribal union, he thinks, is a strong fundamental platform that will allow people to understand better their identity, which in its turn will lead to a rise of national self-awareness and the development of culture. "This will bring the Buryat society to a completely different level of development. We have a single root; this will unite us in a qualitatively different, more fundamental format" (Ochirov and Ian 2016).

The idea of the revival of tribal unions was likewise positively received by representatives of other large Buryat communities - the Bulagats and the Ekhirits. In 2016, the Tribal Union of Bulagats began to organize. One of the authors of this article (M. Sodnompilova) was also a participant in the first meeting of Ekhirits Community devoted to their plans to organize a tribal union.

Ochirov, the leader of the Aga Buryat Community in Ulan-Ude, is convinced that the Khori, Bulagats, Ekhirits and Khongodors are the largest social elements that have made major contributions to the formation of the Buryat ethnonation. In this way, a situation is created in which smaller ethnic groups, such as Tsongols, Sartuls, Tabanguts, Tertes, Shosholoks, Ikinats, Noiots, Zungars, Khurumshis and others, will be looking for 
their place on the new "fundamental platform." It is uncertain whether they will be successful. It is quite possible that for a part of the Buryat people, other ideas of integration will seem more appealing. One of them, formulated not so long ago, deserves special attention.

In the context of the new stage in the development of the Buryat ethnonational idea it is worth noting that also the Buryats of the Barguzinskii ${ }^{8}$ and Kurumkanskii Regions of the Buryat Republic, residing in the Barguzin River valley, regard themselves the basis of a nascent community. According to the Buryat population of these two regions, the place they live in is Bargujin Tokum, a place sacred for all Mongols; in the interpretation of these local activists, this holy land is symbolized by the Barguzin River. Barguts - an ancient tribe, fragments of which are scattered today in Mongolia and the Inner Mongolia Autonomous Region in China - also came from Bargujin Tokum. The ancient ethnonym is recorded in the names of the major ethnic groups Khuushin Barga and Shene Barga, living today in China and Mongolia. However, one should keep in mind that the name of this medieval region is connected not with a hydronym but with the ethnonym Bargu that in the Buryat ethnogenic legends is personified as Bargudai - the progenitor of the Buryats. The widely known ethnogenic myth in which Bargudai is the father of Ilüder, Buriadai and Khoridoi shows that the medieval ethnic community of the Baikal region comprised the forerunners of Ölöts (Oirats), Buryats (Bulagats and Ekhirits) and the Khori,

\footnotetext{
${ }^{8}$ Denoted as Bagruzin in cartography, in the contemporary Buryat language this region is called Bagrazhan.
} 
who remained in the area. The ethnonymic origin of the Bargujin Tokum historic area points to a completely different space in which the ancestors of the Buryats settled, one which is not at all limited to the valley of the Barguzin River. A reconstruction of the map of Bargujin Tokum, based on toponyms derived from the ethnonym Bargu and preserved to this day, made it possible to outline the general area in which the ancient Bargu settled and, accordingly, the boundaries of the Bargujin Tokum, which turns out to cover almost the entire territory of ethnic Buryatia (Nanzatov 2015, 13). This fact did not confuse the present-day inhabitants of the Barguzin Valley and they continue to hold the opinion that it is their land that is the true ancestral home of the Barguts.

The large-scale objective of the "Barguzin" community is the unification of the ethnic group marked by the ethnonyms Bargut and Barga, whose bearers live today in Mongolia and Inner Mongolia Autonomous Region of China (the inhabitants of the Barguzin Valley include themselves in the group automatically). The idea to reconstruct the location of Bargujin Tokum - the ancestral homeland of the ancient Barguts and the territory revered by all the Mongols ${ }^{9}$ - within the boundaries of a definite territory that is the Barguzin River valley has become a special economic and cultural project among the many ideas that were put forward in order to develop tourism in the Republic. In the context of this idea, a new community has emerged which can be designated as the "Bargut." The community has not yet

\footnotetext{
${ }^{9}$ Bargujin Tokum is one of the sacral territories of the Mongolian Empire, singled out by Genghis Khan (Rashid-ad-Din 1999, 299).
} 
defined its official name, as the members consider themselves descendants of either the Barguts or the Barguzin Buryats, whose ancestors came from the territories of upper Lena River. Having nevertheless secured the approval of the authorities, this virtual community received quite real outlines: the Third Bargut International Ethnocultural Festival "Bargazhin-2015," far larger and more extensive than the previous editions, was organized with the support of the Ministries of Culture and Education of the Republic of Buryatia and the Institute for Mongolian, Buddhist and Tibetan Studies of the Siberian Branch of the Russian Academy of Sciences. Guests from China and Mongolia participated in the festival, which was also accompanied by a scientific and practical conference and various cultural events. The aim of the festival was formulated as the promotion of international interaction through acquaintance with ethnic traditions and rising of interest in the culture and art of Barguts living on the territory of the Republic of Buryatia, Mongolia, and Inner Mongolia (Kurumkanskii raion 2015).

At the time of writing these words, the Bargut/Barguzin community is engaged in reconstructing various elements of its culture - including songs, the Iokhor dance, mythology and a heroic epic - and in designing its own "Barguzin" ethnic costume to represent it at the forthcoming Altargana International Festival. According to the idea of the Barguzin enthusiasts, the Barguzin Buryat costume should embody the features of their small homeland and its main symbols: the mountains of the Barguzinskii Range and other features of the landscape, while preserving the traditional features of the costume of the Barguzin 
ancestors - the Upper Lena (Verkholenskie) Buryats. All the best forces have been involved in the costume's reconstruction, among them rural schools, experts in folk heritage, scholars and all those who are not indifferent to the Buryat culture. Residents of the region are very interested in the realization of these cultural projects and take an active part in them.

It should be noted that the Altargana International Festival is one of the largest international ethnic cultural projects of the 21 st century. It was conceived with a view to uniting the Buryats living today on the territory of three states - Russia, China, and Mongolia. In part, it has fulfilled its task, as the Buryat populations of these three countries consider the festival to be the most important cultural event in the region and actively engage in it. The participants undertake serious and lengthy preparations, and competitions are becoming more and more complex and diverse. ${ }^{10}$ Altargana is of special importance to residents of rural areas of the Republic, among whom the traditional culture is reproduced. The villagers see the festival as a good platform for self-presentation. Altargana outshines other ethnonational festivals in the Republic - Surkharban and even Sagaalgan. The awards received in various competitions of the international festival are a source of special pride for the winners and for the regional administration. As a matter of fact, the festival is aimed not simply at revealing best performer of folk songs, wrestler, uligershin (performer of the heroic epos) or connoisseur of rites.

\footnotetext{
${ }^{10}$ Earlier, the traditional costumes worn during the festival were made by masters representing territorial administration units (for example, the Selenginsk Region of the Republic of Buryatia) or particular smaller ethnic groups (for example, the Khongodors) with participation of experts on tradition. But recently fashion design professionals have also began to take part in the work.
} 
Victory in these competitions means recognition of the winner as "the true Buryat," who is most apt at mastering the resources of the cultural heritage of his ancestors and effective at presenting it to the public. Such victory is especially prestigious and desired when the participants include Buryat groups from Mongolia and China, as (in the representations of Russian Buryats) the status of experts and custodians of Buryat traditions is reserved for them a priori.

Such activation of tribal and ethnoterritorial relations determines the situation of social competitiveness within the Buryat ethnonation. Communality, which is one of the dominant features of Buryat ethnicity, nowadays manifests itself at the higher level of tribal associations, while simultaneously transforming the old ethnic (clan) values. The presented examples of how ethnic communities are formed on a new level show that in the Buryat society the process of self-identification continues and at the same time that it does not go beyond ethnicity. Interest in ethnic history is not dying out among Buryats; on the contrary, it is growing. Everyone who studies the ancestry of their family inevitably encounters the problem of the mythical as well as historical origin of the Buryats, and such people in the modern Buryat society are increasing in number, especially among the older generation.

Secondly, one should also take into consideration the political potential that lies in such communities, whose activities are often initiated by the leaders of the ethnonational elite. It is likely that the former zemliachestvo communities based on the administrative-territorial principle will no longer be active and 


\section{influential agents in the political space of Buryatia. At present, their activities do not meet the interests of the national elite and perhaps that is why new ideas arise about the creation of larger and, most importantly, ethnic-based political groups.}

\section{WORKS CITED}

Amogolonova, Darima D. 2008. Sovremennaia buriatskaia etnosfera: Diskursy, paradigmy, sotsiokul'turnye praktiki [The modern Buryat ethnosphere: Discourses, paradigms, sociocultural practices]. Ulan-Ude: Izdatel'stvo Buriatskogo gosuniversiteta.

Baldaev, Sergei P. 1970. Rodoslovnye predaniia i legendy buriat [Genealogal tales and legends of Buryats]. Ulan-Ude: Buriatskoe knizhnoe izdatel'stvo.

Bartaeva, Ol'ga. 2013. “'Uulyn uladai uulzalga' - prazdnik vstrechi gortsev” [Mountain People Assembly - a festival where highlanders meet]. Oka Gazeta website, June 28. Accessed August 18, 2019, http://okagazeta.ru/news/media/2013/6/28/ uulyin-uladaj-uulzalga-prazdnik-vstrechi-gortsev/

Elaev, Aleksandr A. 2000. Buriatskii narod: Stanovlenie, razvitie, samoopredelenie [The Buryat people: Formation, development, self-determination]. Moskva: RAGS.

Elaeva, Irina E. 2005. "Buriaty: Repertuar identichnostei v sovremennom sotsiokul'turnom kontekste (postsovetskii period)" [Buryats: Repertoire of identities in the modern sociocultural context (post-Soviet period)]. In Darima D. Amogolonova, Irina E. Elaeva and Tat'iana D. Skrynnikova, Buriatskaia etnichnost'v kontekste sotsiokul'turnoi modernizatsii (postsovetskii period), 117-223. Irkutsk: Radian.

Kurumkanskii raion. 2015. "III Mezhdunarodnyi etnokul'turnyi festival' bargutov" [3rd International Bargut Ethnocultural Festival]. Kurmanskii raion website. Accessed March 6, 2016. http://kurumkan.burnet.ru/Barguti.php

Nanzatov, Bair. 2015. Bagruzinskii okrug v XIX v. (voprosy etnicheskoi istorii regiona i etnicheskii sostav naseleniia) [Barguzin Region in the 19th century (questions of ethnic history of the region and ethnic composition of the population)]. Vestnik BNTS SO RAN 1 (18): 11-30.

Ochirov, Bato. 2016. "Edinenie khori buriat - eto nachalo novoi obshchestvennopoliticheskoi modeli Buriatii" [Unification of the Khori-Buryats is the beginning of a new socio-political model for Buryatia]. ARD website, February 25. Accessed August 19, 2019. http://asiarussia.ru/blogs/11332/

Ochirov, Bato, and Andrei Ian. 2016. "Khori-buryatskii Sagaalgan - pervyi shag k pereformatirovaniiu natsii" [The Khori-Buryat Sagaalgan is the first step towards the reformatting of the nation]. ARD website, February 20. Accessed March 6, 2016. http://asiarussia.ru/persons/11280/

Rashid-ad-Din. 1999. Fazlullah's Jami u't-tawarikh: A Compendium of Chronicles: A History of the Mongols, translated by Wheeler M. Thackston. Pt. 2. Cambridge, MA: Harvard University, Department of Near Eastern Languages and Civilizations. 


\section{BURYAT ETHNIC SELF-IDENTIFICATION: NEW TRENDS...}

Rumiantsev, Georgii N. 1969. "Idinskie buryaty (rodo-plemennoi sostav)" [Ida Buryats (clan and tribal composition)]. Etnograficheskii sbornik (Ulan-Ude) 5: 76-104.

Tsydendambaev, Tsybikzhap B. 1972. Buriatskie istoricheskie khroniki i rodoslovnye [Buryat historical chronicles and genealogies]. Ulan-Ude: Buriatskoe knizhnoe izdatel'stvo. 


\section{Ayur Zhanaev}

ORCID 0000-0002-8976-8811

University of Warsaw

\section{ALTERNATIVE HISTORY: \\ CREATION, USE \\ AND INTERPRETATION \\ OF BURYAT GENEALOGIES ${ }^{*}$}

\section{ABSTRACT}

Group identities are often built on genealogies. Buryat culture appears to conform to this general rule. Elaborate Buryat historical genealogies have been written and preserved. Today, scholars regard them as a key source of insight into the structure and character of Buryat society. Most scholars treat Buryat genealogies exclusively as descriptions of kinship systems. In keeping with a rich anthropological literature, Buryat culture appears to fit into the paradigm of kinship as the "irreducible principle," "atom" or an "elementary structure," which, as the complexity of society grew, ceased to be the central organizational principle in favor of the state, politics, economy, etc. However, this interpretation occludes the meaning of Buryat genealogies as carriers of historical memory and understanding of the world. By insisting on treating it in ethnographic categories, the academic view of Buryat culture reduces the Buryat society to the level of a primordial one.

In this article, I will use the findings of my fieldwork to briefly introduce the historical context of the Buryat genealogies in the broadly defined pre-So-

* This article is a revised and extended version of a part of my book: The Human Being in Social and Cosmic Orders: Categories of Traditional Culture and the Problems of Contemporary Buryat Identity (Zhanaev 2019, 98-111 - Part 2.4.3. "The Uses of Genealogies: Creating and Contesting Buryat Identity") . 
viet, Soviet and post-Soviet periods. I am interested in the motives of those who created these genealogies, and the place these documents occupy in the contemporary Buryat society and culture. I will also note the coincidence of a revival of interest among Buryats in their genealogies in the 1970s and 1980 s with the rise of Soviet modernization's power to suppress local cultures.

Keywords: genealogies, kinship, social order, history, elites

\section{INTRODUCTION}

In social sciences, kinship is habitually considered to be the "irreducible principle," "atom" or an "elementary structure," which, as the complexity of society grew, ceased to be the central organizational principle in favor of the state, politics, economy, etc. (Branstätdter 2009, 6). However, this concerned mostly the "complex" or "modern" societies of Euro-America, where kinship was being reduced to the nuclear family, while the minimally differentiated societies like that of the Buryats were believed to be still based on kinship ties. Indeed, practically no works on Buryats and the Buryat culture go without the extended study of, or at least reference to, kinship or kinship ideology. This overemphasis on the major role of kinship in patrilineal organization of community, marriage practices, tribalism, labor, property exchange, etc., reflects the Buryats being treated as a typical "kin-based" society. Thus, a host of cultural ideas is attributed simply to kinship, which gets extended almost limitlessly to the whole social structure (Schneider 1984; Carsten 2004).

Genealogies, both those written and those memorized, are often assumed to be evidence of the general organization of 
a society along kinship lines (Sneath 2007, 105). However, I claim that they are not always useful for understanding the kinship relations and that they could function divorced from the social structure. In this article, I will use the findings of my fieldwork to sketch out a brief historical context of Buryat genealogies in the pre-Soviet, Soviet and post-Soviet periods. I am interested in the motives for creating these genealogies, the role of those who created them and the place these documents occupy in the contemporary Buryat society and culture.

\section{GENEALOGIES IN THE PRE-SOVIET AND SOVIET PERIODS}

Genealogies have constituted a significant part of Mongol historiographical tradition at least since the 13th century. This component was under strong influence of Tibetan (Buddhist), Chinese and Russian epistemological cultures but has retained its relevance and significance throughout history. Practices of revising genealogies and manipulating one's origin were common (Kollmar-Paulenz 2014). Especially in the pre-Soviet period, genealogies depended on political (and religious) orientation of the elites. After the Buryat-Mongols became subject of the Russian state in the 18th century, their particular genealogies and chronicles developed relatively independently of one another and did not agree in terms of ancestral origin - there were plenty versions of the legends and names, and no attempts were undertaken to construct a single all-Buryat ancestral ideology (Tsydendambaev 1972, 50). 
The genealogies written in the pre-Sovietization period could be divided into two types. The first type were family histories of nobles, which rather remind records of service and official documents. Clan aristocracy was a part of the indigenous political system but also, through the system of indirect rule, part of the Russian administration, and thus written genealogies were also the way to legitimize the power of a leader or a ruling clan and their heritage (Tsydendambaev 1972, 168). The second type of genealogies were private family genealogies and general genealogies of entire localities (Tsydendambaev 1972, 48). Gradually, genealogies acquired a more general and extensive character and included both the nobles and commoners (Tsydendambaev 1972, 172-3).

Further in the article, I will focus primarily on such extensive genealogies comprising the populations of whole villages. I visited the Khezhenge (Kizhinga) Aimag in 2014 and 2015 to contact with the local people occupied with maintaining the genealogies (harbaalzhi, ugai besheg, ugai dansa) of the villages of Zagustai, Mogsokhon, Khezhenge, Ulzyte, Sulkhara; I also gathered materials concerning the village of Kuorka. I confirmed my findings based on the fieldwork in different regions of ethnic Buryatia which I conducted in close cooperation with my mentor Ewa Nowicka as well as Wojciech Połeć and Blanka Rzewuska in 2012, 2013 and 2014: ${ }^{1}$ and independently

\footnotetext{
${ }^{1}$ The research project "Between Russia, Mongolia and China: Buryats and the Challenges of the 21st Century" was funded by the Polish National Science Center (Grant No. DRC2011/03/B/HS6/01671) and led by Ewa Nowicka. I accompanied Professor Nowicka's team only in Aga Okrug, Ulan-Ude and Khezhenge Aimag of the Buryat Republic, and Khentii Aimag of Mongolia.
} 
in 2015 as well as during summer vacations between 2012 and 2015.

Despite the long tradition of genealogical writing, during my fieldwork I never saw the old pre-Soviet genealogies - one would have to go to the museums and archives to see remnants of the surviving documents. Old genealogies were, however, used by those who gathered the village genealogies later. For example, one of the newer genealogies mentions a genealogical list (ugai dansa) of the head of Khudai Clan written in 1850, and some of the older genealogies that were written on huge "bed-sheetsized" pieces of paper (male, aged 94, 20.07.2014, Khezhenge).

Most of the village genealogies were created during the Soviet time, usually in the 1970 and 1980s. To my mind, this is not accidental, since it was the time when the "model minority" began realizing that with the advancing paces of Soviet modernization, it was losing its culture and language (Chakars 2014). As in other places of the world, the local elites played the key role in shaping the cultural content. This was also true of the genealogists, who could all be counted among the local intelligentsia, for usually they were either teachers or local historians (kraeveds). During my fieldwork, I contacted people who took upon themselves the task of gathering local genealogies. Usually, there are one or two seniors in every village or locality who started gathering the genealogies in their youth. Many of the genealogists that I was able to locate have since died, though their work is sometimes continued by people of other generations. Thus, I had to contact their close relatives or people who would remember them. It was also very interesting 
to trace their personal background and motivation for gathering such material. As far as I found out, these persons usually did not have any "noble" origins which could indirectly point to their continuing of the family tradition or legitimizing their leading position in the community, as it is said to have been the case with pre-revolutionary chroniclers. Gathering the genealogies was their personal initiative - it was not a task which they were obliged or expected to perform. Collecting the material was quite a hard task for them, which they supported from their own funds.

A 94-year-old citizen of Khezhenge started gathering genealogies in his youth and used older records written in the classic Mongolian script, modifying the information based on his fieldwork. He keeps the records in a few notebooks, each concerning the residents of one village: Khezhenge, Ulzyte, Sulkhara etc.

I began with the old records. There was also a man called Ochirzhapov Dondog, born in 1912, who performed the work [of documenting genealogy - A. Zh.] on his own village called Khuurai. Sulkhari was recorded by another old man; and I took the material from the museum in Mogsokhon, then I took material from one man in Khezhenge. From everywhere I could. It is not a work that could be just memorized, even if it concerns events that happened a year or two ago; it is also based on the older records. Apart from that, I went to meet people, visit every family and ask what their ancestry/lineage [ug] was, whether they knew or not. If one knew, I wrote it down, and if not - I didn't. It is not just my work that went into this, everything is based on the older records (male, aged 94, 20.07.2014, Khezhenge).

The genealogists thus used pieces of genealogies written before and the materials gathered by other local historians. 
In the written genealogy kept in Mogsokhon, the author TsyrenNamzhil Ochirov even listed the names of some of his main informants who knew the local lineages by heart. Interestingly, genealogists also personally contacted and consulted one another. Their major research method were interviews. Interviewing the local families must have been hard work, which was perhaps not especially encouraged or, at least in some periods, discouraged altogether. The daughter of another genealogist remembers the way her father used to gather material in the 1970s and 1980s:

He would go to every person. He would take his case and travel to Khori [Khori District], to Khezhenge, to Chesaan, he would go everywhere, even to the city [Ulan-Ude], ask people from there, go here and there, here and there ... It was the Soviet time and people did not pay attention to his work, they did not think it was of any importance (female, aged 65, 19.09.2015, Khezhenge).

The situation is still very similar nowadays. People usually do not care much about maintaining the village genealogy, even if they consider it a praiseworthy thing. The role of updating and gathering information is put squarely on the shoulders of the local intelligentsia, who are all of senior age and not sure whether the records will be continued after their death:

After that [the death of the previous genealogist] nobody cared about it. I was puzzled by this and had to ... the new names ceased being recorded and it just finished. I do not know what will happen with it afterwards, will there be a person who could continue it or not ... The majority of the data I gather myself. They do not care that much ... If they move to the city [Ulan-Ude], there are people whom I ask [in the village]. I ask people. Here I go to the ambulance clinic to ask about the newborn children; of course, I have many people who were not recorded here (female, aged 80, 19.09.2015, Khezhenge). 
The interview was taken in 2015, when I came back in 2016, I learnt that the 80-year-old woman had unfortunately already passed away. I was told that during her funeral the work she did was announced to the mourners and volunteers were sought who would continue her work, but I do not know whether any were found. All in all, the genealogies in the Soviet period were compiled by local elites who realized the gradual loss of the Buryat culture - it was not, as the apparent lack of new genealogists perhaps proves, a matter of public demand.

Apart from the extensive village genealogies, people often keep lists of their forefathers' names on a piece of paper. Such written genealogies are considered a sort of cultus image, kept in special places together with representations of deities and family photos. The genealogies of this kind that I was shown were compiled recently, often noted down from the village genealogies or consulted with senior members of the family.

At least two important things could be seen here. Firstly, the written genealogies were not necessarily used for maintaining the social order: recognizing one's relatives does not always imply a deep knowledge of the ancestors. It seems clear that the village genealogies, both those compiled in the recent past and the contemporary ones, were used neither for maintaining exogamy, arranging marriages nor for distributing property. They do not serve as documents having any role in arranging the community structure currently, either. This has been so predominantly because though they reproduce local lineages, the connection with the clan ancestors should be considered 
outside of biological categories. They are more a symbolic way of creating and then identifying the past. That is one of the reasons why these written genealogies are not the reflection of the social order or people's relations with each other.

Secondly, the genealogies comprising the population of whole villages are (like the villages themselves) a rather recent phenomenon that appeared in the Soviet times together with changes in the administrative structure. ${ }^{2}$ Perhaps the genealogies which previously were used by the elites, for example in the distribution of inheritance and power, in the Soviet conditions lost many of their functions. After the appearance of collective farms, the abandonment of genealogies might have been one of the techniques used to attract people to these new communities. Later on, when the diminishing of the Buryat culture became evident, the genealogies took on another important function - the construction of historical myths. As we shall see, the history thus produced was alternative to that written in official books, it described the "great ancestors" instead of the "backward nomads."

\section{THE CONTENT OF GENEALOGIES}

The content of the genealogies presented the multiple local views of alternative history, contrasting with the Soviet modernist historiography. The genealogies contain in fact not merely

\footnotetext{
${ }^{2}$ The rise in popularity of genealogies seems to be much more common among Buryats than in Mongolia, which is perhaps connected with the processes of sedentarization of Buryats (Sławoj Szynkiewicz, personal communication) or with the spread of shamanist practices (Bulag 1998; Shimamura 2014)
} 
names of people and the scheme of their relatedness with one another but also short histories, explanations and remarks. They look more like a kind of textbooks on local history, where one could trace the lot of one's own family in the context of many centuries. The reader is struck by the great number of names of both dead and living people collected over just a few sheets. Not all the lineages are treated equally - some of them stretch seven, others as many as 25 generations back. Besides the names, some of them contain information about profession, character and biography of people living several generations ago. For example, included in the genealogies of Mogsokhon written by Tsyren-Namzhil Ochirov is a story of Butid, a noble man's daughter born in 1889:

Butid, having arrived as a wife to Dorzho, whom she did not like, sang the following song ... Before this, they tried to marry her off to Bambain Seren, and she used to sing this song: "The head of the Council in Anaa/ Says that he wants me as his wife/ Is it really the result of good deeds [buian] of my father and mother?/ Is it really my luck? ..." (Ochirov 1980).

Various phrases people once uttered, remarks on their character and other fragmental testimonies are also to be found on the sheets. Next to some of the names, there are records about the person's occupation - usually lama or shaman (böö) or the place where they used to settle and their migration routes:

Gonchig, gabzha [rank in the Buddhist clergy], used to travel in China; ... Dainsha, [who] was a shaman, willed to have his dead body left on the top of Mount Hepkhien Uula, but people found it to be too far and instead left it on the top of Mount Gazar-Sagaan, they say (Ochirov 1980). 
Apart from that, all possible data are included of people who contributed to building stuppas or datsans, or distinguished themselves with special achievements, profession and education. Most genealogies begin or conclude with general information about the Khori Buryats, containing their ancestry and some historical events. In Zagustai, I even saw a Soviet reprint of a 19th century Buryat historical chronicle kept together with the genealogy. The name of Genghis Khan or names of other significant people in Mongol history are not rare in those pieces. Perhaps then, the village genealogies, along with manuscripts in the classic Mongolian script - written in both the pre-Soviet and Soviet periods - should be considered rather as records of local history, an alternative (though not always opposing) one to that abundantly created in the official Soviet discourse.

\section{GENEALOGICAL TRADITION IN THE POST-SOVIET PERIOD}

These deeply rooted but unofficial historical narratives come out of the shadow during the "cultural revival" in the post-Soviet period. The early 1990s saw the publication of twenty Buryat chronicles and other works transliterated form the Old Mongolian script to modern Buryat (L. Badmaeva 2005, 8), and recently eleven chronicles were translated into Russian and became even more available. This has revived genealogical narratives not only as versions of history, but also as reflections of destroyed social structures. 
I would venture to call the modern nostalgia for clan and tribe divisions an influence of European evolutionist conceptions of society development and their application to the Buryat community, first during the Tsarist and then the Soviet period, through education and academia. The kinship-centric character of the Buryat community was, and is, emphasized often enough in most of the ethnographic and historic works to have become an important element of the Buryats' casual reflections on their own society. The Buryat terms associated with social structure and institutions are interpreted in terms of kinship solidarity - and consequently translated as "clan," "tribe," "houses," etc. Commonly, instead speaking of the "Buryat population," scholars use the cliché of buriatskie rody - "Buryat clans" - even in contexts when clan solidarity is doubtful. Kinship solidarity and clan division became a sort of a priori knowledge that predetermined the character of the whole vocabulary. David Sneath notes that in texts like The Secret History of the Mongols (ca. 1237), a series of different terms related to social organization, such as irgen (people, subject), ulus (polity, realm, patrimony, appanage), aimag (division, group), were translated as "tribe" in places where the considered unit was believed to be tribal. Similarly, the term "clan" was very often used to denote any group which the translator believed to be a clan (Sneath 2007,62 ). Interestingly, the paradigm of Buryat social organization based on "clans" formed in the Russian Empire and then itself became the major interpretational grid for the academic researches on other Mongol communities, which, however, were shaped under the strong influence of Qing Empire policies 
(Mönkh-Erdene 2011, 31). The local social structures were considered in this essentialized way, although in ontological terms they generally did not share much with the colonial background of those writing the official histories and ethnographies.

In the nature-culture discourse, increasingly popular in the post-Soviet period, the Buryats find their place to be closer to "nature," which apart from strong associations with backwardness has also the seemingly attractive hues of "noble savageness." The clan and tribe divisions are now described as the natural, and thus more authentic and moral, form of social organization in comparison to the "modern," less "spiritual" structures. One of the authors of a contemporary genealogical book writes in the preface that according to some researches, $70-80 \%$ of the surveyed Russian students do not know the names of their grandfathers and grandmothers - this poor knowledge of the genealogy is then contrasted to the sophisticated system of the Buryat genealogies as a certain proof of Buryat superiority (Tsydenov 2014, 11). Some other researchers also note that extended knowledge of their origin was seen by former nomads as the point of superiority over sedentary Europeans (Zapaśnik 1999).

In the modern Buryat discourse, genealogies go hand in hand with the supposed clan division. During fieldwork in ethnic Buryatia, the Polish anthropologists whom I accompanied were frequently told that each Buryat can name the last seven generations of their ancestry, though according to my personal experience this exists merely as an ideology. Many of the people with whom I talked would remember their genealogy as 
children, but could not recall it anymore in adult life. Knowing and declaring the knowledge of one's ancestry is a source of pride, of confirmation and at the same time propagation of the vital forces (sülde) s $^{3}$ one's immediate family, but it is not knowledge that is important in social structuring. The ways the image of kinship community really does function in the modern context are best shown by the examples of the Buryat children education, the publishing of books and genealogies and other similar projects.

Schoolteachers, who in the recent Soviet past were rather important mediums of Sovietization, currently are often occupied with "revival of Buryat culture." An old woman to whom I talked was surprised to hear that religion and "clan issues" are taught and encouraged in schools. Indeed, the educational system was the key part of Soviet modernist and cosmopolitan ideology (Chakars 2014, 119). Nowadays, however, for many Buryats, mass events (cf. Nowicka 2016) and schools are the only sources of Buryat ethnic culture: "introduction of the youth to the knowledge about the ancestry [ug garbal] is a holy duty of the whole nation and most of all of the teachers" (B. Badmaeva 2009, 29). Projects whose goals are in line with Badmaeva's call are provided on different levels of school educational system, and are realized most commonly by teachers of the Buryat language and literature within the "Regional Component" included into the curriculum of regional schools. Apart from multiple undertakings aimed at the revival of the endangered Buryat

${ }^{3}$ For more on the topic of vital forces see: Humphrey and Ujeed 2012; Skrynnikova 2012; Tangad 2013. 
language, customs and rituals - these projects also mention the clan and tribe division, presenting it as an important element of the traditional culture. The data on the genealogies, clans and tribes are sought in academic works, which enjoy almost absolute authority - perhaps this is another example of the use of ethnographic data in nationalist ideology. The local genealogical records written during the Soviet period, which were described above, also become important sources in the reconstruction of tradition, though a few years earlier they were not as popular.

What is interesting is that since the clan and tribe division of the Buryats is presented as an object of national pride - all other discourses, associated with "backwardness," are omitted or reinterpreted. The teachers whom I interviewed believe it to be an important tool for propagating "moral values" and "stronger unity of family, ties between generations, instilling respect towards the ancestors" (Tarnueva 2009, 11-2), which "will not let children forget about the native land, beloved father and mother, and merited people" (B. Badmaeva 2009, 29). During lessons of the Buryat language, in school clubs and at various contests, children present their genealogies, and "tribal" and "clan" origin. Such tasks are also assigned to university students during the Buryat language classes. Students consult with the elder members of their family or relatives who know the genealogical lineage by heart or have it in the written form. Usually, most of the young people are able to reconstruct them seven generations back, but there are also many of them who go back as far as 25 generations. Each genealogy represents a line of names until the mythical tribal ancestor. For example, 
almost all genealogies presented in Khezhenge derived from one and the same ancestor, Khoridoi Mergen, the son of Barga Bagatur. Such genealogies, known, kept and now written down in separate families, are useless for ranging the social distance, for they are quite isolated and contain no information about relatedness with other genealogies. The best and the longest genealogies and essays are granted awards and prizes. As one of the teachers told me, such projects will help children to have their genealogies reconstructed and written down, and from then on serve as a source of precious memories for their families.

Scholars note that copies of genealogies suddenly started to spread among people in the early 1990s, on the wave of national 94 revival in Buryatia (Zhambalova 2008, 76). Such genealogies, published in books and tables, serve as a popular wedding gift, and are often exhibited during the wedding ceremony and other gatherings. However, the form of the genealogies has changed significantly: they are concerned with a territory and the clans that have gathered on it, not the separate clans themselves. They have also started to include names of women - which in the older pieces were as a rule omitted - as some researchers did not like the fact that mothers were not included in genealogies and have proposed the genealogical schemes that included them (Lubsantseren and Tserenchimed 2009, 120).

Interestingly, while the Buryat mythical ancestors are numerous and diverse (from various all-Mongol ancestors to Indian and Tibetan kings), most of the contemporary genealogies tend to come down to one of the three ancestors which have been accepted by the majority of the Buryat local groups. 
The ancestors are derived from the legend of Bargu-Bagatur (descendant of the Burte Chinu-a), who had three sons: Oliudai, Buriadai and Khoridai (see, e.g., Tsydenov 2014, 23; Aiushiev $2013,11)$. The first son is the ancestor of the Oirats - Western Mongols, nowadays commonly associated with the Kalmyks; the second son, Buriadai, is the forefather of the Western Buryats; and Khoridai - of the Khori and Aga Buryats. This legend, first recorded in a historic report by Dorzhi Darbaev (1839), has been preferred to others, and often reproduced and used in other projects related to clan revival. The tradition is still alive and developing. However, it does not embrace the large part of numerous southern Buryat groups (the Tsongool, Sartuul, Tabanguud, Khotogoid, Khatagin, and others, all of whom migrated from Khalkha Mongolia), groups which have played significant, if not central, roles in Buryat history.

Most people do not know the clan affiliation of other people, nor do they strive to know it. It is not information shared between people, though almost every family keeps the memory of their clan and refers to it during rituals. However, there are numerous attempts to "revive" the supposedly traditional division, at least during some national holidays and public events. Thus, during the Lunar New Year feast in 2015, people gathered on the central square in Khezhenge at a certain moment were encouraged to divide according to their clan affiliation. It is symbolic that the group thus formed consisted primarily of people many of whom had never met one another before and who certainly did not think of one another as kin. This state of communitas was temporary; created during the event "for fun," 
it quickly dissolved when the event was finished. This and other examples above show that the clan system exists merely as an ideology created by the local elites, whereby it is presented as part of the "lost tradition" that requires reviving. It departs from the actual social division, which is organized according to principles other than kinship.

\section{CONCLUSION}

I began my article by embedding the Buryat genealogies within the Mongol historiographical tradition. Later, I showed how this tradition developed in the Soviet period as an alternative to the mainstream texts of history, and how it later gained currency in the post-Soviet period (as a history alternative to the official one). I then discussed in brief some of those who wrote them and those who used them, and concluded that the function of genealogies in social organization was minor in comparison to their other functions, like the construction of historical myths, ideologies, and being the object of religious devotion.

This analysis of the process of creating, functioning and interpretation of genealogies contributes to the general discussion in the humanities about "Who owns history?": it is not only a matter of the "practical past" (White 2010) but also of the "practical interpretation of the past." The theory of kinship was a frame applied limitlessly in academic research, a generally accepted theory which prevailed with few exceptions in all major orientations of the humanities as a kind of "conventional wisdom” (Schneider 1984, 43). 
The written genealogies circulating among contemporary Buryats should be considered more as an alternative to official versions of history than a means of constructing or reconstructing real kinship relations between people. The genealogies should be perceived outside of biological connotations: they are not always useful for understanding the social distance and kinship relations (Szynkiewicz 1992, 68).

\section{WORKS CITED}

Aiushiev, Dashi S. 2013. Zhenkhen-galzuty Verkhnego Barguzina [The Zhenkhen Galzut of the Upper Barguzin]. Ulan-Ude: Izdatel'stvo Buriatskogo gosuniversiteta. Badmaeva, Baiarma Zh. 2009. "Khotyn hurguuliin khesheelnüüd: 'Minii ug garbal' gehen sedeb tukhai" [On "My genealogy" lessons in urban schools]. In Genealogicheskaia kul'tura Buriat: Sovremennyi nauchno-obrazovatel'nyi diskurs, 29-31. Ulan-Ude: Izdatel'stvo Buriaad Ünen.

Badmaeva, Larisa B. 2005. Iazyk buriatskikh letopisei [The language of Buryat chronicles]. Ulan-Ude: Izdatel'stvo SO RAN

Branstätdter, Susanne, and Gonçalo D. Santos. 2009. "Chinese Kinship Metamorphoses." In Chinese Kinship: Contemporary Anthropological Perspectives, edited by S. Branstätdter and G. D. Santos, 181-203. New York: Routledge.

Bulag, Uradyn. 1998. Nationalism and Hybridity in Mongolia. Oxford: Clarendon Press.

Carsten Janet. 2004. After Kinship. Cambridge: Cambridge University Press.

Chakars, Melissa. 2014. The Socialist Way of Life in Siberia: Transformation in Buryatia. Budapest: CEU Press.

Humphrey, Caroline, and Hürelbaatar Ujeed. 2012. "Fortune in the Wind: An Impersonal Subjectivity.” Social Analysis 56 (2): 152-67.

Kollmar-Paulenz, Karénina. 2014. "Systematically Ordering the World: The Encounter of Buriyad-Mongolian, Tibetan and Russian Knowledge Cultures in the 19th Century." Études de lettres 2-3: 123-46.

Lubsantseren, B., and L. Tserenchimed. 2009. "Ezhineerei ugai besheg” [Genealogical lists of mothers]. In Genealogicheskaia kul'tura buriat: Sovremennyi nauchno-obrazovatel'nyi diskurs, 120-30. Ulan-Ude: Izdatel'stvo Buriaad Ünen.

Mönkh-Erdene, Lkhamsuren. 2011. "Mongolyn tusgaar togtnolyn iogt ür dagavar: Mongolchuudyg mongolzhuu, Mongol ulsyg olon iastny bolgoson n", [An irony of Mongolia's independence: Making the Mongols Mongolic and Mongolia multi-ethnic]. In Mongolyn tusgaar togtnol ba Mongolchuud, edited by 
S. Chuluun, 25-40. Ulaanbaatar: Mongol Ulsyn Shinzhlekh Akademiin Tüükhiin Khüüreelen.

Nowicka, Ewa. 2016. Korzenie Attargany sięgaja głęboko [Altargana's roots run deep]. Kraków: Nomos.

Ochirov, Tsyren-Namzhil O. 1980. Harbaalzhi (ugai modon) [Tree of origin], manuscript kept in museum of the village Mogsokhon

Schneider, David. 1984. A Critique of the Study of Kinship. Michigan: Michigan University Press.

Shimamura, Ippei. 2014. The Roots Seekers: Shamanism and Ethnicity Among the Mongol Buryats. Kanagawa: Shumpusha Publishing.

Skrynnikova, Tat'iana D. 2013. Kharizma i vlast'v epokhu Chingis-khana [Charisma and power in the epoch of Genghis Khan]. Sankt-Peterburg: Evraziia.

Sneath, David. 2007. Headless State: Aristocratic Orders, Kinship Society, and Misrepresentations of Nomadic Inner Asia. New York: Columbia University Press.

Szynkiewicz, Sławoj. 1992. Pokrewieństwo [Kinship]. Warszawa: Wydawnictwa Uniwersytetu Warszawskiego.

Tangad, Oyungerel. 2013. Scheda po Czyngis Chanie: Demokracja po mongolsku [Genghis Khan's legacy: Democracy Mongolian style]. Warszawa: Trio.

Tarnueva, Soiolma B. 2009. Teoriia i metodika sostavleniia rodoslovnoi [Theory and methodology of genealogy research]. Kizhinga: n.p.

Tsydendambaev, Tsybikzhap B. 1972. Buriatskie istoricheskie khroniki i rodoslovnye: Istoriko-lingvisticheskoe issledovanie [Buryat historic chronicles and genealogies: A historical and linguistic study]. Ulan-Ude: Buriatskoe knizhnoe izdatel'stvo.

Tsydenov, Aleksandr D. 2014. Rodoslovnaia: Zolotoi fond gargintsev [Genealogy:

A treasury of the Gargi]. Ulan-Ude: Izdatel'stvo Buriatskogo gosuniversiteta.

White, Hayden. 2010. "The Practical Past." Historein 10: 10-9.

Zapaśnik, Stanisław. 1999. Ród w społeczeństwach Azji Centralnej [The clan in Central Asian societies]. Unpublished manuscript.

Zhambalova, Sesegma G. 2008. "Sokhranenie i vozrozhdenie genealogicheskoi traditsii u buryat" [Preservation and renaissance of Buryat genealogical tradition]. In Mir Tsentralnoi Azii-2, edited by B. Z. Nanzatov, 68-76. Ulan-Ude: Izdatel'stvo BNTs SO RAN.

Zhanaev, Ayur. 2019. The Human Being in Social and Cosmic Orders: Categories of Traditional Culture and the Problems of Contemporary Buryat Identity. Warsaw: Wydawnictwa Uniwersytetu Warszawskiego. 


\title{
Kamil M. Wielecki
}

ORCID 0000-0003-0211-9884

University of Warsaw

\section{THE SPIRIT THAT PERMEATES}

THE HUMAN SOUL:

\section{ANTHROPOLOGY, NATIONAL EPIC, \\ AND NATION-BUILDING \\ IN KYRGYZSTAN}

\begin{abstract}
The paper discusses the uses of the myth of Manas in post-Soviet Kyrgyzstan. Manas, the biggest cultural hero of the Kyrgyz people, is considered the Father of the nation. The Epic of Manas, in turn, is considered the longest ever written, and serves as a synecdoche for all Kyrgyz culture. Based on my ethnographic fieldwork research, I argue that the content of the epic has only a loose connection to ways in which it has been applied in practice as a key element in the Kyrgyz nation-building process after the dissolution of the Soviet Union. I briefly refer to the content of the epic and a few theories on its provenance. Next, I describe Manas Ordo - a big architectural complex built around the symbolic tomb of Manas - as well as many controversies attached to the place. Finally, I describe the national policies of post-Soviet Kyrgyzstan's first president, Askar Akaev, and comment on the crucial role of native anthropology in the construction of national ideology in contemporary Kyrgyzstan.
\end{abstract}

Keywords: Epic of Manas, nation-building, national ideology, Kyrgyzstan, Askar Akaev, anthropology 
There is a long tradition of treating The Epic of Manas as a synecdoche of Kyrgyz culture. In a quote that appears in almost all publications on Manas, Chokan Valikhanov - the 19th century Kazakh Russian military officer, historian and ethnographer who first wrote down a piece of the epic - calls it the Iliad of the Steppe and the Encyclopedia of the Kyrgyz people. As he put it,

Manas is an encyclopaedical collection of all the Kirghiz mythological tales and traditions, brought down to the present period and grouped round one person - the giant Manas. It is a species of Iliad of the Steppe. The Kirghiz mode of life, their morals, geography, religious and medicinal knowledge, as well as their relations with other tribes, all find illustration in this compendious epopee (Valikhanof and Veniukof 1865, 101).

This approach of considering Manas a microcosm in which the entire Kyrgyz culture is represented is nowadays reproduced in a number of forms: by Kyrgyz politicians, anthropologists and philosophers, people who pilgrim to sacred sites connected with the epic, and many others. Manas is believed to be the longest epic ever written. It has been recognized as an element of Intangible Cultural Heritage of Humanity by UNESCO and constitutes a source of national pride. What has changed since the times of Valikhanov's expeditions is the way in which the narrative gets publicized. Today, Manas is not only sang by manaschys - singers or tellers of the epic. It is transmitted by countless publications, radio and TV broadcasts, cartoons and movies. Monuments have been erected and popular slogans have been drawn on mountain slopes, fences and billboards. A scientific subdiscipline has emerged - 
Manasology (in Kyrgyz: manastaanuu, in Russian: manasovedenie) and whole academic institutes and universities have been named after Manas.

The Epic of Manas has been extensively described from linguistic and literary point of view by Kyrgyz, Russian, Soviet, and international scholars. ${ }^{1}$ A lot of effort has also been put into reconstructing the historic environment in which the epic emerged, with many competing theories on what Manas is really about. I present a few of them in this article. However, I would like to go beyond the epic itself. More precisely, I would like to investigate how the myth of Manas has been proliferated in post-Soviet Kyrgyzstan. Based on my ethnographic fieldwork research, ${ }^{2}$ I argue that the content of the epic has only a loose connection to ways in which it has been used in practice. In fact, there are several Manases - the Manas of the epic, the Manas of religious worship, the Manas who inspires the manaschy to sing about him, the Manas of Kyrgyz anthropology, and - last but not least - the Manas of politics. Askar Akaev, the first president of independent Kyrgyzstan, was a key player in the latter aspect. As I am going to show, it was because of him that the myth of Manas was used as a crucial element in the

\footnotetext{
${ }^{1}$ For extended bibliographies of the topic see, for instance, Aliev, Sarypbekov and Matiev 1995; Hatto 1980; Jumaturdu 2016; Reichl 2016.

${ }^{2}$ I conducted three extensive research trips to Kyrgyzstan between 2003 and 2007. In 2005, for six months, I was an exchange student at the Kyrgyz National University in Bishkek and witnessed the so-called Tulip Revolution that brought an end to Askar Akaev's reign. Altogether, I lived in Kyrgyzstan for more than eight months, and researched the issues of folk healing, worship of sacred sites and worship of Manas. I briefly referred to Manas and the phenomenon of manaschy in contemporary Kyrgyzstan in my other publications (cf. Wielecki 2015a; Wielecki 2015b). Nevertheless, the material I present in this study has remained largely unpublished. Only in retrospect did I realize in how important a period for Kyrgyzstan I happened to be there.
} 
construction of Kyrgyz national ideology after the dissolution of the Soviet Union.

First, I briefly present the content of the epic and follow a few major theories on its provenance: which historical events the narrative recounts and who its main protagonist might have been. Next, I describe Manas Ordo - a big architectural complex built around the symbolic tomb of Manas. The complex is highly controversial. On the one hand, it is revered by many visitors as mazar - a sacred site. On the other, however, it was constructed and widely promoted by the state and thus some people point to its artificial character. I focus on the ways in which Manas - or rather his spirit - reveals himself at the place. In the 102 third section, I describe the policies of Akaev and his application of Manas in the construction of Kyrgyz national identity. In conclusion, I make some comments on the role of anthropology - or as Kyrgyz intellectuals prefer to call it: philosophy in the nation-building processes in post-Soviet Kyrgyzstan.

\section{MANAS IS LIKE A NAPOLEON CAKE: ON THE ORIGINS AND CONTENT OF THE EPIC}

Manas is definitely the biggest cultural hero of the contemporary Kyrgyz. He managed to save and unite his people. He defeated enemies and led many successful war expeditions he is even said to have captured Beijing. As many Kyrgyz people believe, he drove the Kyrgyz from the Altai Mountains (alternatively, some indicate the upper Enisei River, in today's Khakassia, as the original Kyrgyz territory) to Ala-Too, the 
areas occupied by them at present. Manas is called Ata which means Father - the Father of the nation. A popular etymology of the word Kyrgyz says that this name arose from the combination of the words kyrk (forty) and kyz (girl). Forty companions of Manas were supposed to meet forty girls, marry them, and - in this way - give origins to forty Kyrgyz tribes.

As was already said, several competing interpretations of the roots and content of the epic have been put forward. Valikhanov was the first researcher to record the epic in 1856. He met a Kyrgyz manaschy, Nazar Bulatuly, and wrote down his performance on the funeral feast of Kukotai Khan. Valikhanov considered this piece to be the most important part of the epic and translated it into Russian a few years later. His report, including the famous description of Manas as "the Iliad of the Steppe," became foundational for the further Manas studies, even though the original record of Bulatuly's performance was found in Valikhanov's archives only in the 1960s (Hatto 1969, 344; Moldobaev 1995, 13; Valikhanov 1985 [1861], 349-51; Wikipedia, s.v. "Valikhanov, Chokan Chingisovich").

The Epic of Manas in a more thorough version was first published in 1885 in German by Vasilii Radlov (Radloff 1885) ${ }^{4}$ as a part of his monumental, 10-volume collection of oral poetry of Turkic peoples of the Russian Empire (Radloff 1866-1907).

\footnotetext{
${ }^{3}$ Surprisingly enough, while in Michells's translation into English from 1865 the piece on the "Iliad of the Steppe" is present (Valikhanof and Veniukof 1865, 101), passages on Manas that follow this passage in the Russian original of Ocherki Dzhungarii have not been translated. Therefore, I refer here to the original text.

${ }^{4}$ There are two version of the name in use, depending on academic tradition - Russian: Vasilii Vasil'evich Radlov, or German: Friedrich Wilhelm Radloff.
} 
Radlov depicted Manas as the greatest among Muslim heroes. He divided the epic into seven episodes, even though he knew that it comprised in fact a trilogy that consisted of Manas, Semetei and Seitek - Semetei and Seitek being, respectively, son and grandson of Manas (cf. Moldobaev 1995, 13-6). All the main characters of the entire plot already appear in this edition: besides the eponymous heroes, also Kanykei - wife of Manas, Alambet - Chinese friend of Manas, Bakai - teacher and advisor of Manas, Kongurbai - Chinese khan, the main adversary of Manas, and Aichorok - wife of Semetei.

Next, the epic was extensively investigated by Soviet linguists and ethnographers in the 1920s and 1930s - Belek Soltonoev, 104 Vasilii Bartol'd, and Saul' Abramzon, among others (Imanaliev et al. 2011, 15-8). Kaium Miftakov and Ibragim Abdrakhmanov recorded and prepared for publication the variant performed by the famous manaschy Sagymbai Orozbakov. Despite the devoted support of many Kyrgyz politicians and intellectuals, the idea of full publication of the narrative in Kyrgyz and Russian was blocked due to the rise of Stalinism (cf. Akaev 2003, 64-5; Wikipedia, s.v. "Epic of Manas," "Kasym Tynystanov"). The first Russian translations - covering only excepts of the epic - were published in the 1940s as: Manas (Dzhakishev and Mozol'kov 1941), The Great Campaign (Dzhakishev et al. 1946), and Magnanimous Manas (Lipkin 1948).

A general tendency in interpretation of the epic in the Soviet times was to present it as a part of folklore. In Russian, it was called a bylina, which is a tale or a legend. Thus, Manas was placed among countless other myths and tales of ethnic 
groups inhabiting the Soviet Union. In short, it was labelled folk wisdom preserved in the form of oral poetry. This way of interpretation was most likely deliberately used by advocates of the epic, who in their attempts to promote it also somewhat diminished it. They presented Manas as something traditional, from the sphere of folk fairy tales and stories told by old people, rather than as a cultural heritage which would distinguish the Kyrgyz among other nations of the USSR. In short, as something harmless to Soviet ideology.

However, the nation-building potential of the narrative was clearly understood. Andrei Zhdanov condemned it as an example of bourgeois cosmopolitanism. Others accused it of nationalism, propagation of Pan-Turkic and Pan-Islamic ideas and conservation of feudal-patriarchal remnants. Some called manaschys the enemies of the nation. In Kyrgyzstan, further editions of Manas were banned in 1952. Such a negative reaction to the publication of the epic was probably connected with the successful communist revolution in China in 1949. As the USSR came to closely cooperate with the People's Republic of China, The Great Campaign, an account of the Kyrgyz conquest of Beijing, was no longer politically correct (Akaev 2003, 64-5; Wikipedia, s.v. "Epic of Manas"; Ukudeeva 2001).

During the thaw after the death of Stalin, studies on Manas were again allowed. A second recording of Manas, based on performances of renowned manaschy Saiakbai Karalaev, was a big achievement. First, transcriptions were done between 1935 and 1947. In the 1960s, in turn, Karalaev's singing was tape recorded. His variant, being perhaps the most popular, 
served along with that of Orozbakov's as foundation for the full, four-volume edition of the epic in 1984-1995. Both are considered classical today.

In Karalaev's rendering, The Great Campaign episode plays an especially important role. It starts with a confederacy of twelve Kyrgyz khans against Manas, gathering their troops to invade the hero's territory. However, they are challenged and beaten by his forty companions. Humiliated, they approach Manas and propose a common military expedition against China. The hero, disregarding advice of Bakai and Kanykei, agrees. The expedition is successful due to the help of Almambet, who remains in an ambiguous position - invaluable ally for the Kyrgyz 106 and traitor for the Chinese. Manas captures a big war booty and becomes khan of Beijing for six months. Then he decides to come back to Ala-Too, the Kyrgyz homeland. On the way back, however, while performing the namaz, he gets attacked by Kongurbai. As the prayer cannot be interrupted, Manas is vulnerable and Kongurbai manages to hurt him with a poisoned spear. The Kyrgyz hero is still able to accomplish many heroic acts. For instance, he manages to kill Kodzhodzash, a giant who thanks to his magical bow earlier exterminated all the companions of Manas. The hero then gets back to Talas, where he eventually dies from wounds and poison (cf. Rakhmutallin 1995).

There are as much as 65 recorded variants of the epic stored in the archives of the Kyrgyz Academy of Sciences, and new ones are still being gathered (Imanaliev et al. 2011, 6). The main points of the plot - like migration from the Altai to Ala-Too, marriage of Manas to Kanykei, conquest of China - appear 
in most, if not all of them. Nevertheless, the variants also significantly differ among themselves in describing different characters and places, presenting various sequences of events, they deliver contradictory interpretations, etc.

This makes it difficult to determine the overall message of Manas. There are vehement discussions about the proportions between the history and myth that are intertwined in the epic. As noticed already by Radlov while commenting on different incoherencies in the songs he recorded, "it is absolutely impossible to present in written form the epos as it exists in the people's consciousness. Indeed, the epos is a poetic reflection of the people's life in a broad sense of the notion, as well as the people's innermost aspirations, ideals, hopes, ambitions, aims, and efforts" (Radlov 1995b, 263). ${ }^{5}$

Some events and descriptions of places in the epic can be referred to historical facts. There are also several mentions of oral poetry about Manas in different chronicles and accounts, the first one being perhaps the 15 th century Persian manuscript Majmu' at-tawarikh (Jumaturdu 2016, 289). In locating historical origins of the epos, various theories have been offered. Radlov claims that in the times of his research - the second half of the 19th century - the Kyrgyz lived in "a 'true epic period.' This period is very much similar to that in the Greek history, when their epic songs about the Trojan war were not written down yet, living in the verbal form narrated and passed down

${ }^{5}$ I follow here an existing English translation of Radlov's text. In the Russian translation, the quoted passage says: "[The epic] is the popular consciousness itself, living in the people and changing along with them" (cf. Radlov 1995a, 33). 
from generation to generation always remaining in the people's memory" (Radlov 1995b, 255). To him, Kyrgyz social memory was ahistorical and widely penetrated by myth. He therefore accentuated the mythological layer of the epic and located the historical layer in recent, 18th century wars. ${ }^{6}$ He also stated that the strong presence of Islam in the epic - including such issues as interpretations of Manas's expeditions as religious struggle against Kalmyk and Chinese pagans - was just a recent incorporation (Radlov 1995b, 262).

Mukhtar Auezov and Alexander Bernshtam, in turn, stress the historical layer of the epic and locate its origins much earlier. Based on Orkhon-Enisei grave inscriptions and Chinese chronicles, they state that the epic emerged during the 9th century wars between the Enisei Kyrgyz and Uyghurs. The Great Campaign is in fact an account of the capture of Ordu-Baliq, the capital of the Uyghur Khaganate, in 840. Aeuzov rejects the interpretations asserting that the Kyrgyz have ever conquered China. As in Kyrgyz Ordu-Baliq was called Beitin, the name got conflated with Beijing later on. About the conqueror of OrduBaliq we know only that he died in 847, the name "Manas" is probably a later addition (Auezov 1995, 375). Auezov also notices that the ancestral tribe of Manas - called in the epic the Cumans - indicates Kipchaks, otherwise known as Polovtsy. The Cumans migrated to south-east Europe in the 11th century; thus, Manas describes the time before that, when they still lived in Central Asia (Auezov 1995, 383). 
Also Bernshtam devotes a lot of effort to explaining the names of tribes that appear in the epic and determining the place of their actions. He claims that the Kalmyks - the main enemies of the Kyrgyz in the epic - denote the Uyghurs. The general categories used in the epic were probably the following: the nomad adversaries were called Kalmyks while the settled ones - the Chinese (sometimes also the Kokands) (Bernshtam 1995, 409). The Kyrgyz themselves were often called the Khakas and were described in the Chinese chronicles as Gekun or Jiankun. Bernshtam states that in general, the epic recounts events from 8-9th centuries, namely the period from the decline of the Enisei Kyrgyz Khaganate (after Uyghur conquests in 710-711 and 758) up to its subsequent rise (the 840 expedition). The action of the epic takes place in the Upper Enisei basin, the Altai Mountains, Mongolia, Ala-Too, today's Uzbekistan and the Uyghur state in eastern Turkestan. Referring to the literary layer of the epic, Bernshtam notes numerous borrowings from other epics of Turkic peoples, particularly from the narrative on Oghuz Khan, but also from the Persian Shahnameh. This explains why some variants of the epic report expeditions in which the Kyrgyz historically did not participate (Bernshtam 1995, 409). For instance, Manas is often said to have captured the Caucasus Mountains. Both Auezov and Bernshtam unanimously agree that apart from the account of Kyrgyz-Uyghur wars, in large parts the epic deals with much later events - even from the first half of the 20th century.

Like Radlov, both Auezov and Bernshtam skip over the Islamic content in Manas, treating it as a superficial influence 
in the narrative. Moreover, they make a subversive claim that the hero was a Manichean. The name "Manas" does not appear in historical sources, it is also not a Kyrgyz one. Bernshtam puts it straightforwardly: "we see a relationship between the names Manas and Mani, the founder of the religious teaching of Manichaism” (Bernshtam 1995, 412-3). In Central Asia, Manicheism was propagated by the Uyghurs, numerous Syrian and Persian missionaries were also active. Many Turkic leaders, as attested by their grave inscriptions, converted to Manicheism. Also Auezov is inclined to accept a Manichean denomination of the historical prototype of Manas, although he asserts that the name might have stemmed from a shamanist deity, as well (Auezov 1995, 375). Additionally, while reflecting on the name of Manas's grandfather - Nogai - Bernshtam wonders whether this was not an ethnonym, questioning the Kyrgyz roots of the prototype of Manas. The term Kyrgyz itself seems to be a relatively late addition to the epic, it seldom appears even in the Karalaev's variant (cf. Rakhmutallin 1995). Neither the Manichean denomination nor the claim about foreign origin of Manas were supported by scholars in independent Kyrgyzstan.

What post-Soviet Kyrgyz scholars usually did do was to move the date of birth of the epic much further back than the Kyrgyz-Uyghur wars. For instance, public intellectual and well-known Manas researcher Shailoo Akmoldoeva has formulated a hypothesis that the Kyrgyz are descendants of Old Aryan tribes who migrated from the Middle East (or India), and then, through Russia, reached Europe, and are the ancestors of modern Europeans. This hypothesis is in contradiction to official 
version of Kyrgyz history and even to the very plot of the epic. Akmoldoeva nevertheless insists on putting emphasis on the mythological roots of the narrative which - according to her - stem from India and date back 5,000 years (Akmoldoeva 1996, 25-30). She claims that the name "Manas" comes from the Sanskrit and denotes the first man, bearer of intellect. Referring to the question of historicity of Manas, she told me:

Manas was not a real historical figure. Do you understand that? It was not a real historical figure, there were a lot of prototypes of Manas. The Epic of Manas... it is similar to the Napoleon cake - the bottom thin layer of pastry is mythology and the remaining filling are thick layers of time: events from the 8th, 9th, 10th, 18th and of the 19th century...

Apart from that, she also subscribes to the tradition of treating Manas as a synecdoche of Kyrgyz culture.

So if you want to know the history of Kyrgyz culture, you need to read Manas. This is just the key to the entire culture. ... Manas is a national hero. Every Kyrgyz boy wants to be similar to his ancestor Manas. Every girl wants to be like Kanykei (female, aged ca. 65, 06.06.2005, Bishkek).

Even more fuel to the debates around the origins of the Kyrgyz and genesis of Manas was added by two state-organized celebrations: one of the 1,000th anniversary of existence of The Epic of Manas in 1995, the other of 2,200 years of Kyrgyz statehood in 2003.

\section{MANAS ORDO: THE CONTROVERSIAL $M A Z A R$}

Nobody knows where Manas was buried - Kanykei hid his body in a secret place so that his enemies would not find it. 
However, a symbolic place of burial lies close to the village of Tash-Aryk, some 15 kilometers from the town of Talas, the former capital of Manas's mythic state, today a regional capital in the west of Kyrgyzstan. On the occasion of the 1,000th anniversary of the epic in 1995, the Soviet-era-built Manas Ordo (Manas's Abode) park was reconstructed to a big architectural complex. It features the so-called Dome or Mausoleum of Manas (Kyrg. Manastyn Kümbözü), Manas Museum, a sacrifice house, a traditional healers' center, a hippodrome for playing kök börüü - a national Kyrgyz game, as well as a gigantic monument to Manas surrounded by monuments to his forty companions. In short, it has become a place of 112 pilgrimage, healing rituals, and tourist traffic and as such is both sacred and controversial, the latter due to its top-down and massive character.

When you enter the Manas Ordo, you encounter a small row of trees. At each of them, a signboard has been installed that informs who planted it. The first was planted by President Akaev, the next ones by representatives of different states and UNESCO. The participation of the latter organization in the millennial celebrations was a big diplomatic success of the Kyrgyz government at that time. UNESCO not only declared the 1995 the Year of Manas but also included the epic in the list of Intangible Cultural Heritage of Humanity. Both initiatives significantly contributed to the internationalization of the celebrations. Nevertheless, as I am going to show, the main goal of organizing the millennium was a domestic one. 
The Dome itself is decorated with Arabic inscriptions, among which the date of erection is visible $-1341 .^{7}$ However, it is crucial to mention here that during the reconstruction in the 1990s, an old mausoleum - which was already a ruin at that time - was dismantled, and a new one, similar in shape, was built in its stead. One can thus say the Dome is only a copy. An inscription on the front side of the building says that Kenizek-Khatun, daughter of Emir Abuka was buried there. This is largely ignored by visitors coming to the place. According to them, Kanykei erected the Mausoleum to commemorate her husband, having hidden his body in the mountains so that it would not become loot of enemies. The inscription devoted to Kenizek-Khatun was just a decoy. What is more, the exhibition of Manas Museum says that a skeleton of a two-meter-tall man was found during excavations at the Dome. The exhibition does not state it directly but the fact is interpreted by visitors in an unequivocal way: this was the skeleton of Manas. All in all, the tomb is of ambiguous status - it is at the same time fake and original, ancient and new, symbolic and material.

The Dome is obviously the main destination for pilgrims coming to Manas Ordo. Nevertheless, there are also other sacred places on the territory of the park and in its neighborhood. The closest ones are the two rocks next to the tomb; they are called Manastyn Chakmak Tashy and Manastyn Tölgö Tashy, i.e. Manas's lucky knucklebones stone and divination rock.

\footnotetext{
${ }^{7}$ Russian archaeologists Mikhail Masson and Galina Pugachenkova confirm this date. On the area of today's park, they also found pieces of ceramics and remnants of buildings from the 12th and 13th centuries, i.e. from the Mongolian times (Aitpaeva 2007, 17).
} 
The tomb is overlooked by the famous Karool Choku, the mountain from which Manas watched for approaching enemies. Indeed, this was a suitable spot for a vantage point - Karool Choku rises alone over the plain of the Talas River valley. The peak of the mountain is called the Throne of Manas. Other important places - albeit located already outside the complex, in the nearby village of Ak-Dzhar - are the sacred springs of Kanykei and Aichurok. Another, small and little-known, sacred site is Kamyrdyn Beli, the Graveyard Pass, located a kilometer north from the Mausoleum, next to a defunct local cemetery.

The presence - both material and spiritual - of Manas at Manas Ordo defies the law of non-contradiction. The same 114 interview partner could repeat the legend about the hiding of the hero's body in the mountains and then claim that archaeologists had found a skeleton of a gigantic man there and that these were the remains of Manas. The Russians became a contemporary version of barbarian enemies plotting to kidnap the body of the deceased hero:

Many clairvoyants came here and said that they recognized some supernatural phenomena at the place. Many Muslims arrived and said that indeed they felt the presence of the spirit of Manas... Probably in 1948, there were excavations, and the anthropologists said they had found a big skull...

Was that the skull of Manas?

Yes, likely.

Where is the skeleton now?

In Leningrad (male, aged 38, former director of Manas Museum at Manas Ordo, 20.06.2005, Tash-Aryk).

Various discursive practices mixed in expressions of visitors to Manas Ordo, forming a peculiar nexus of reasoning aimed 
at proving the spiritual presence of Manas. Even the people who asserted that the hero was not buried there, stressed that in any case he had stayed there during his life. He had a vantage point at the top of Karool Choku, he treated his wounds in the miraculous springs nearby, it was there where Kanykei would wait for him and bid him farewell when he set off on war expeditions, and so on. A symbol requires material embodiment, otherwise it becomes an abstract commonplace. Thus, even if people agreed that treating the tomb of a khan's daughter as the tomb of the national hero was merely a convention, the connection of the present to mythological past was reproduced in manifold ways. If not the building itself, other signs - the stones next to the Mausoleum, the Karool Choku Mountain, the springs, etc. - marked the presence of Manas and thus transformed the place into his real grave.

Visitors to Manas Ordo - who had different educational and professional backgrounds, had different attitudes towards the myth, were characterized by various levels of religiosity named various reasons why the place was special. Most of them talked about the spirit of Manas. Others said it was Allah who was at work there. Many people also maintained, which was not contradictory to the two previous positions, that there was a special power or energy beaming in the complex.

All that has made Manas Ordo an important mazar. The term mazar derives from the Arabic word for grave. In Kyrgyzstan and in Central Asia in general, it denotes a sacred site, which might be an ossuary of a saint or a hero, or a commemoration of an event. For instance, at Nyldy Ata - the largest mazar 
complex in the Talas Oblast - a rock is worshipped, called Akkulanyn Mamysy, Akkula's Hitching Post. Manas once spent a night there and tied his horse Akkula to that rock. A tree at Nyldy Ata, in turn, is called Semetei Ata Turgan Dzheri, literally "the place in which Semetei Ata once stayed." Some natural peculiarities can be considered mazars, too - for example a tree growing lonely in a barren land. Each sacred site has its own guardian spirit - it is the spirit of a person buried at the place or a mythological personality. The visitors should revere the spirit and may appeal to him or her with different requests. Usually a spring is an obligatory element of a mazar; the water from it is considered to have healing properties. In general, 116 one can distinguish between two kinds of sacred sites: natural (trees, mountains, stones, lakes) and man-made (mausoleums, caravanserais, old buildings). ${ }^{8}$

Most people perceive Manas Ordo as a powerful mazar. It is particularly popular among individuals dealing with spiritual and healing practices, who are generally categorized as köz achyk ("open eyes") and include: the bübü and bakhshy (female and male shamans), folk healers, manaschys, fortune tellers, etc. These people have their own house at the complex, where they can perform their rituals. However, Manas Ordo is visited mostly by ordinary people who come there in order to perform sacrifice and pray: to ask for blessing or a solution to a problem, or to give thanks for something.

${ }^{8}$ In legal terms, a mazar is defined as a natural site or an object built by man that is considered sacred and visited by worshippers in order to conduct rituals, pray and praise God. The sacred sites and their surroundings belong to the historical and cultural heritage of the Kyrgyz Republic and thus cannot become private property of a person or institution (Aitpaeva 2007, 218). 
Many also come just to rest and take in some of the special aura of the place.

Nevertheless, for various reasons, Manas Ordo is also a highly controversial place and some people deny it sacredness. As the aforementioned Shailoo Akmoldoeva put it:

People decided to treat the Mausoleum as the "mazar" of Manas. However, if you take into consideration archeological findings, this was a grave of the daughter of the khan; Manas is beside the point here! I always say Manas was a mythological personality, not a real and historical one. You cannot find his bones, it is not serious. People simply decided to call this building this way. ... I myself, for example, I do not even want to go there; for me, it is not interesting, all of that is artificial, you understand. ... It was made just for foreigners, to show them Talas - the homeland of Manas... (female, aged ca. 65, 06.06.2005, Bishkek).

Manas Ordo is therefore rejected due to its artificial character: its popularity did not arise from a massive bottom-up worship but was boosted by the state. In addition, for many people, the complex is simply too much of a tourist site. It is visited by some 200-300 people daily, which is a lot if you want to treat it as a place in which to rest, let alone achieve spiritual purification: the more visitors, the greater the risk of uncleanness and defilement of ritual purity (cf. Douglas 1966). Moreover, there is no water spring in the area of the complex (the Kanykei and Aichorok Springs are located outside of it) and - unlike many natural sacred sites - the place is easily accessible and does not take much effort to get to. Last but not least, Manas Ordo - like all other places revered by people as sacred - is criticized by orthodox Muslims: worship of people and places is forbidden in Islam. 


\section{MANAS AND POLITICS: NATION-BUILDING IN POST-SOVIET KYRGYZSTAN}

The Soviet policies were oriented on putting objects of worship behind the museum glass, to show them as legends - i.e. relics of the past. Notwithstanding, President Akaev - the author of the idea of the new Manas Ordo - turned the legend into a powerful symbol which started to unite many: clairvoyants and folk healers, Muslims and lay people, ordinary visitors, and even scientists. As he himself put it, "after the celebrations of the 1,000th anniversary of The Epic of Manas, the Manas Ordo complex gained a national status. This place became a second Mecca, a place which every Kyrgyz citizen who considers him or herself a descendant of Magnanimous Manas should visit" (Akaev 2002, 240). ${ }^{9}$ Akaev did not hesitate to make other grandiose religious comparisons. In another place, he compares Manas to Moses; the former led the exodus of the Kyrgyz out of Altai (taken to mean "the vast territory from Lake Baikal to the eastern foreland of the Tian-Shan") to the Promised Land of Talas (Akaev 2003, 54). What is more, for every Kyrgyz person, the epic - Akaev claims - is like the Holy Scripture, and Manas has been a sacred symbol worshipped by the Kyrgyz throughout the ages (Akaev 2003, 47). For religious people, comparing Manas Ordo with Mecca or Manas with the Bible may sound like blasphemy.

\footnotetext{
${ }^{9}$ It is meaningful that Akaev uses in this place the term Kyrgyzstanets (a Kyrgyz citizen) instead of Kyrgyz (an ethnic Kyrgyz). This shows that in Akaev's intention, Manas was supposed to unite different ethnic groups inhabiting Kyrgyzstan.
} 
Unlike other prospective leaders of Central Asian countries, Askar Akaev was not the First Secretary of his Republic's local Communist Party in the Soviet times. He was a scientist, professor of physics. His political career sped up in 1989, when he was, first, appointed the president of the Kyrgyz Academy of Sciences and next elected to the Supreme Soviet of the USSR. In 1990, he took the newly created post of President of the Kyrgyz SSR. In December 1991, following the Belovezha Accords, he became the first president of the emergent Republic of Kyrgyzstan. In 1995, he was re-elected to this office, and a change of the Constitution allowed him to take the post also in 2000 - for the third term. In March 2005, as a result of a political coup dubbed "the Tulip Revolution," he was ousted from power. He fled to Russia.

Akaev was a very active media figure. Out of many books he wrote, two are important in the context of nation-building processes in Kyrgyzstan: The Kyrgyz Statehood and the National Epic "Manas" (Akaev 2002) and The History That Passed Through My Heart (Akaev 2003). It is there that he offers glimpses into the national ideology in the making and explains the rationale behind different anniversaries and state celebrations that played an essential role in his historical and nation-building policies. The year 1993 was celebrated under the slogan Kyrgyzstan - Our Common Home. The slogan has become very popular, as attested to by numerous billboards printed throughout the next decades. Since that time, too, the term Kyrgyzstanets has started to be used in the language of politics. It indicated all citizens of the country, not only the 


\section{Kamil M. Wielecki}

ethnic Kyrgyz. In fact, writing about 1993, Akaev declares he does not perceive the term Kyrgyz itself to be ethnically based.

In my opinion, in the historical understanding, the real Kyrgyz are those ethnic groups that for centuries lived on our territory, defended it from foreign assaults, sacrificed their lives here, watered the nurturing land with their blood and sweat. That is why I am particularly fond of the national idea Kyrgyzstan - Our Common Home. Our land was a common home in the past, it has remained so until today and I am sure that it will forever remain so in the future (Akaev 2002, 48).

A symbolic sign of unity of all citizens of Kyrgyzstan is the so-called House of Friendship, built in the center of Bishkek. Associations of many national minorities and ethnic groups have their seats there.

The year 2003, in turn, was celebrated as the 2,200th anniversary of Kyrgyz statehood. Like in the case of the millennium of The Epic of Manas, Akaev managed to place the celebrations in the official calendar of UNESCO for the year. The idea of the anniversary came up in June 2002, during Akaev's visit to China, when the Chinese leader presented him with a testimony, in which Sima Qiang - an ancient Chinese traveler and historian - mentioned the Kyrgyz people (called Jiankun at that time). Qiang's chronicle Shi Ji says that the land of the Kyrgyz was conquered by the Huns in 202-201 BC. According to the Chinese historian, the land was located in "the eastern foreland of Tian-Shan" or in "Western Mongolia." Akaev tries to pinpoint the precise location and supposes that the ancient Kyrgyz people lived probably at the Kyrgyz Nur Lake and in the Borohoro Mountains (Akaev 2002, 16-7). In another place, he maintains that the Kyrgyz have never fought against the Chinese 
and both nations have maintained friendly relations throughout the ages. The Kyrgyz have never captured Beijing and so the Great Campaign episode is in fact an account of a war against the Uyghurs, not the Chinese (Akaev 2003, 52). All in all, Qiang's testimony allowed Akaev to conclude that a Kyrgyz state had to exist at the turn of the 2nd century BC - and so 2003 saw pompous celebrations of 2,200 years of Kyrgyz statehood.

However, it was the celebrations of the 1,000th anniversary of The Epic of Manas in 1995 that were most important for the creation of a national ideology for Kyrgyzstan. In his writings, Akaev admitted that in 1946, there were plans to celebrate the 1,100 th anniversary of the narrative. The plans were based on the most popular interpretation of the provenance of the epicthat its events took place in the 8-9th centuries. Akaev took that interpretation for granted, this - however - did not prevent him from celebrating the 1,000th anniversary five decades later.

Akaev's slogans, intended to strengthen national identification among citizens, were widely promoted. In the streets of Kyrgyz cities and towns, you can often find various posters, boards or concrete pillars with slogans like Flourish, our beautiful Kyrgyzstan! or A healthy child will be born in a healthy family. In Talas, I was surprised by a huge inscription laid out of white-painted stones on the side of a mountain, saying Program - the Spirit of Manas XXI. It probably meant that the spirit of Manas survived until the 21 st century and that he had a program for the country. As I found out later on, school children were sometimes sent - as part of their physical education activities to nearby mountains to paint stones and lay educational maxims 
out of them. In one village, I came across what might have been a fence or a monument built out of prefabricated concrete slabs, on which the Seven Commandments of Manas were written in large letters. The heading read, Commandments of Manas Kyrgyz State Ideology. In one of his books, Akaev confesses to have formulated the Commandments himself for the purposes of the 1995 celebrations. As he clarifies, however, he did not express his own opinions but the common will of the people, because "the Seven Commandments of Manas are considered the most respected ethical and moral standards among Kyrgyz people" (Akaev 2002, 68). The Commandments, sometimes called also the Lesson of Manas, as elaborated by Akaev, preach:

1. Unity and solidarity. "The meaning of all of Manas's accomplishments lies in uniting his nation"; his eventual defeat was due to feuds among the Kyrgyz.

2. Harmony, friendship and cooperation between nations. The commandment is related to the slogan Kyrgyzstan - Our Common Home. It is illustrated by friendship of Manas and his Chinese fellow Almambet. "It is our sacred duty to do everything we can so that sons and daughters of different nations, who live on the Kyrgyz soil by the will of fate, may feel at home here, surrounded by their kindred people and becoming genuine citizens of Kyrgyzstan who support their country with all their souls."

3. National honor and patriotism. Manas and his companions were guided by these sacred concepts in most difficult times.

4. Through constant, painstaking work and knowledge - to prosperity and welfare. Manas always gathered wise people around him and won with their help. "Scrupulous work constitutes a sacred duty of every citizen. Without it, a man will not fulfill his main destiny in this world and the country will never prosper."

5. Humanism, magnanimity, forbearance. The national character of the Kyrgyz was formed as a result of the spiritual impact of the epic. The epithet magnanimous, which is the descriptive title of Manas, points to the main trait that the epic instills, which is humanism. This 
is rooted in the notion that man constitutes a bridge between past and future generations. The health of society thus depends on the health of the family, and "the Epic is a real hymn to the woman - wife and mother - and her sacred work." Kanykei is the model for the commandment.

6. Harmony with nature. "If we were able to revive today the former attitude towards nature, known in the times of Manas, we could become carriers of the world's highest philosophical and ecological culture. And we would be able to pass Ala Too to our descendants with its beauty multiplied." To fulfill this Lesson, 2001 was declared the Year of the Mountains (and later 2004 - the Year of Tourism).

7. Strengthening and defending of Kyrgyz statehood. An implementation of this commandment was the slogan Kyrgyzstan - a Country of Human Rights (which served as a leading motto in 2002). Today, the Kyrgyz people undertake another Great Campaign, this time for a decent life (Akaev 2002, 420-3).

Elsewhere, Akaev states that "the Kyrgyz nation is God's most valuable gift that stems from the most ancient times" (Akaev 2003, 46). He adds that The Epic of Manas constitutes a great spiritual power that unites the nation. For the ancient Kyrgyz, the epic served as a kind of folk constitution, a set of moral laws and principles, a code of honor and customs, and a testament for future generations (Akaev 2002, 419-20). It also has an impact today - for example, Kyrgyz soldiers killed in the fight against the Islamic Movement of Uzbekistan, whose militants attacked the south of Kyrgyzstan in 1999, demonstrated "truly Manasian qualities of bravery and dedication to the nation" (Akaev 2002, 267). As the former President concludes, Kyrgyzstan is probably the only state in the world that owes its existence to a national epic (Akaev 2002, 424).

One should remember that in 1995, when Akaev introduced Manas as national ideology, Kyrgyzstan was still a newborn state 
that had recently raised itself from the ashes of the USSR. In 1991, he assumed presidency of a country that became an independent state for the first time in modern history - if not for first time ever. Granted, the contemporary Kyrgyz refer their statehood to medieval khaganates of the Enisei Kyrgyz or even to earlier formations - as the 2,200th anniversary shows - but the connection is loose. A big step was made in 1924 when as the authors of a university textbook put it - "as a result of practical implementation of the national policy of the Bolshevik Party and the Soviet authorities, the Kyrgyz regained their statehood after more than 1,000 years" (Ploskikh 2000, 195). Namely, the Kara-Kyrgyz Autonomous Oblast ${ }^{10}$ was created within the Russian Soviet Federal Socialist Republic. As the authors maintain, the year 1924 was of great historical significance. It accelerated the consolidation of the Kyrgyz people into a nation and saw the beginning of the process that led to the creation of a fully sovereign Kyrgyzstan (Ploskikh 2000, 202). Nevertheless, neither the Kara-Kyrgyz Autonomous Oblast nor the subsequent Kyrgyz SSR can be called independent states. The true sovereignty was achieved only in 1991.

As all other post-Soviet republics, in the 1990s, Kyrgyzstan was tormented by a major social and economic crisis. Moreover, ethnic tensions - previously kept at bay by the strong state started to erupt. When in 1989 Kyrgyz was introduced as the official state language, ${ }^{11}$ the Kyrgyz constituted only $52 \%$ of the

\footnotetext{
${ }^{10}$ In the nomenclature of that time, the population of today's Kyrgyzstan was described as the Kara-Kyrgyz (the Black Kyrgyz), and that of today's Kazakhstan as Kaizak-Kyrgyz.

${ }^{11}$ In the new language law introduced in 1989, Russian was described as language of "interethnic communication" but did not have the state language status.
} 
country's population, with the Russians making up $22 \%$, and Uzbeks $13 \%$. The remaining Kyrgyzstanis were representatives of about 90 other nationalities and ethnic groups (Anderson 1999, 41-2). In the following years, the country underwent massive migration movements, including first and foremost an outflow of Russians. The borders between the former Soviet Republics became problematic as soon as they acquired real significance. This caused, among other results, frequent KyrgyzUzbek conflicts in Osh and Jalal-Abad Oblasts. Unsurprisingly, Akaev was in search of an ideology that would unite the very troubled and divided society. He eventually found it in Manas. Deeply impressed by the theory of passionarity formulated by Lev Gumiliov, Akaev imagined himself as a great passionate leader that would head a new Kyrgyz ethnogenesis (Akaev 2002, 492-502; cf. Gullette 2008).

\section{CONCLUSION}

In this article, I briefly sketched the content of Manas and presented a history of research on the epic. I also mentioned a few, at times contradictory, interpretations regarding the provenance of the narrative and possible historical prototype of the main hero. In the next section, I described the Manas Ordo architectural complex, which was erected in connection with celebrations of the 1,000th anniversary of the epic in 1995. I elaborated on the issue of Manas's presence at the place. On the one hand, the so-called Dome of Manas is as a matter of fact a grave of a khan's daughter. On the other, 
however, other objects at the complex and in its neighborhood mark a connection with a mythological past: stones in front of the tomb, Manas's watchtower mountain, the miraculous springs of Kanykei and Aichorok. As a result, Manas Ordo is controversial in character: for many people, it constitutes a powerful mazar, the most sacred site in Kyrgyzstan. For some, on the contrary, it is artificially constructed by the state and thus profane. Finally, I described the role of President Askar Akaev and the nation-building processes launched by him in the 1990s. It was him who turned the narrative into a national ideology oriented on unifying the very diverse Kyrgyz society. He did so by way of organizing state celebrations, like the 1261,000 th anniversary of the epic or the 2,200th anniversary of Kyrgyz statehood. It was also him who made a selective use of the narrative - like the formulation of the Seven Commandments of Manas - and orchestrated its propagation via the mass media.

As I claimed, The Epic of Manas became the keystone of national identity in post-Soviet Kyrgyzstan. Obviously, this was not done by Akaev alone. Along him, a broad range of politicians, social activists and public intellectuals - like Shailoo Akmoldoeva, whom I mentioned in this paper - was involved in filling what sometimes was called an ideological void created after the fall of communism. In my opinion, however, there was no void, as culture is something in a constant statu nascendi. What was there were urgent questions that concerned national, social and personal identifications of Kyrgyz citizens, and the answers were quickly found in the mythological past. History 
is not a collection of objective facts: it is rendered by social memory and adjusted to the present needs (Hastrup 1987).

Interestingly enough, all of the people involved in nationbuilding processes dealt with anthropology: studying myths, cultural values, features of national character, the nomadic way of life, customs and beliefs. What I call anthropology, Kyrgyz scholars usually call philosophy. Philosophy of the Kyrgyz is a class often taught at Kyrgyz universities; Manas is the inherent part of the syllabi. Akmoldoeva told me:

I am a professional philosopher. When I returned to Kyrgyzstan [from Moscow], I started to deal with the epic. ... It was still the Soviet times, the 1980s, all my friends said that I dealt with fairy tales. "Why did you study philosophy, to investigate fairy tales?" ... And I asked myself why don't the Kyrgyz have their own philosophy? (female, aged ca. 65, 06.06.2005, Bishkek).

This is meaningful as it does not pertain only to Akmoldoeva. Many of Kyrgyz intellectuals, having received their Marxist education during the Soviet times, started to speak about one myth in independent Kyrgyzstan: that of the renaissance of Kyrgyz culture, nation, and state. In the introduction, I wrote that today Manas is transmitted in many ways, not only told by the manaschys. Akaev, Akmoldoeva and other engaged people have become modern singers of the epic. Thus, instead of singular manaschys, there is a choir singing about Manas today. Or, in other words, the spirit of Manas sings about himself in many voices.

Some statements of my interview partners suggest that the philosophy of the Kyrgyz might indeed be called a peculiar Phenomenology of Spirit: 
Therefore, no one should know where he is buried. But you can summon his spirit. He comes, meets people and explains. Everyone has in their breast thousands of millions of words of Manas. Every Kyrgyz keeps Manas in their soul (male, aged 55, deputy director of Manas Museum at Manas Ordo, 25.06.2005, Manas Ordo);

Whoever considers themselves a Kyrgyz is always supported by the spirit of Manas (male, aged ca. 30, doctor of Kyrgyz philology, 27.06.2005, Talas);

And you just find out that there is the spirit. You cannot invent it, you cannot describe it. ... When they sent our fathers to fight in World War II ... or when we see our boys off to the army, we think, deep in our soul: "May God and the spirit of Manas protect you" (female, aged 61, doctor of chemistry, 17.06.2005, Talas).

Perhaps every nationalism, any building of a state or creation of a national language involves an invention of tradition (Hobsbawm and Ranger 1983, 13-4). Obviously, in this case, it is not the tradition that is new - the epic has been passed orally for centuries - but the meanings that have been attached to its content. However, this happened according to the very nature of oral heroic poetry: epics grow over time, as they develop and incorporate new elements. The success of the state ideology proposed by Akaev lay in the fact that it fit perfectly into the entire cultural context - beliefs in the presence of spirits of ancestors and mythological characters here on earth, worship of sacred places, as well as the multi-ethnic society and the memory of nomadic past. After all, everything that the Kyrgyz have finds illustration in this compendious epopee. 


\section{THE SPIRIT THAT PERMEATES THE HUMAN SOUL...}

\section{WORKS CITED}

Aitpaeva, Gulnara A., ed. 2007. Mazar Worship in Kyrgyzstan: Rituals and Practitioners in Talas. Bishkek: Aigine Cultural Research Center.

Akaev, Askar. 2002. Kyrgyzskaia gosudarstvennost' i narodnyi epos "Manas” [The Kyrgyz statehood and the national epic "Manas"]. Bishkek: Uchkun.

Akaev, Askar. 2003. Istoriia, proshedshaia cherez moe serdtse [The history that passed through my heart]. Moskva, Bishkek: Ilim.

Akmoldoeva, Shailoo. 1996. Drevnekyrgyzskaia model' mira: Na materialakh eposa "Manas" [The ancient Kyrgyz model of the world: Based on the material of the Manas epic]. Bishkek: Ilim.

Aliev, Satybek, Raikul Sarypbekov and Kadyrbek Matiev, eds. 1995. Entsiklopedicheskii fenomen eposa "Manas" = Encyclopaedical Phenomenon of Epos "Manas." Bishkek: Glavnaia redaktsiia Kyrgyzskoi Entsiklopedii.

Anderson, John. 1999. Kyrgyzstan: Central Asia's Island of Democracy? Amsterdam: Taylor \& Francis.

Auezov, Mukhtar O. 1995. "Time of the epos 'Manas' origin.” In Entsiklopedicheskii fenomen eposa "Manas" = Encyclopaedical Phenomenon of Epos "Manas," edited by S. Aliev, R. Sarypbekov and K. Matiev, 374-400. Bishkek: Glavnaia redaktsiia Kyrgyzskoi Entsiklopedii.

Bernshtam, Aleksandr N. 1995. "Epoch of the Kyrgyz epic 'Manas' origin.” In Entsiklopedicheskii fenomen eposa "Manas" = Encyclopaedical Phenomenon of Epos "Manas," edited by S. Aliev, R. Sarypbekov and K. Matiev, 402-25. Bishkek: Glavnaia redaktsiia Kyrgyzskoi Entsiklopedii.

Douglas, Mary. 1966. Purity and Danger: An Analysis of Concepts of Pollution and Taboo. London: Routledge \& K. Paul.

Dzhakishev, Umarkul, Evgenii Mozol'kov, Il'ia Sel'vinskii and Konstantin K. Iudakhin, eds. 1946. Manas: Kirgizskii epos: Velikii pokhod [Manas: A Kyrgyz epic: The great campaign], translated by Semen Lipkin, Lev Pen'kovskii and Mark Tarlovskii. Moskva: OGIZ \& Khudozhestvennaia literatura.

Gullette, David. 2008. "A State of Passion: The Use of Ethnogenesis in Kyrgyzstan." Inner Asia 10 (2): 261-79. https://doi.org/10.1163/000000008793066768

Hastrup, Kirsten. 1987. "Presenting the Past: Reflections on Myth and History." Folk 29: 257-69.

Hatto, Arthur T. 1969. “'Kukotay' and 'Bok Murun': A Comparison of Two Related Heroic Poems of the Kirgiz - II." Bulletin of the School of Oriental and African Studies, University of London 32 (3): 541-70. https://doi.org/10.1017/S0041977X0009707X

Hatto, Arthur T. 1980. "Kirghiz (Mid-Nineteenth Century)." In Traditions of Heroic and Epic Poetry II: Characteristics and Techniques, edited by A. T. Hatto, 300-27. London: Modern Humanities Research Association.

Hatto, Arthur T. 1997. "Tradition and Change in the Kirghiz 'Manas." In Languages and Scripts of Central Asia, edited by S. Akiner and N. Sims-Williams, 99-105. London: School of Oriental and African Studies, University of London. 


\section{Kamil M. Wielecki}

Hobsbawm, Eric, and Terence Ranger, eds. 1983. The Invention of Tradition. Cambridge: Cambridge University Press.

Imanaliev, Kanybek K., Raisa Z. Kydyrbaeva, Asylbek A. Bakirov, Zhyldyz K. Orozobekova, Talantaaly A. Bakchiev, and Nelia Kh. Bekmukhamedova. 2011. Manasovedenie: Uchebnoe posobie [A textbook of Manas studies]. Bishkek: KRSU. Jumaturdu, Adil. 2016. "A Comparative Study of Performers of the 'Manas' Epic." Journal of American Folklore 129 (513): 288-96. https://doi.org/10.5406/jamerfolk. 129.513.0288

Lipkin Semen. 1948. Manas velikodushnyi: Povest'o drevnikh kirgizskikh bogatyriakh [Magnanimous Manas: A tale of ancient Kyrgyz heroes]. Moskva, Leningrad: Gosudarstvennoe izdatel'stvo detskoi literatury.

Moldobaev, Imel B. 1995. Manas: Istoriko-kul'turnyi pamiatnik kyrgyzov [Manas: A historical and cultural site of memory of the Kyrgyz]. Bishkek: Muras.

Mozol'kov, Evgenii S., and Umarkul Dzhakishev, eds. 1941. Manas: Kirgizskii narodnyi epos [Manas: A Kyrgyz folk epic], translated by Semen Lipkin and Mark Tarlovskii. Moskva: Khudozhestvennaia literatura.

Ploskikh, Vladimir M., ed. 2000. Istoriia Kyrgyzov i Kyrgyzstana: Uchebnik dlia vuzov [History of the Kyrgyz and Kyrgyzstan: A university textbook]. Bishkek: Ilim.

Radloff, Wilhelm. 1866-1904. Proben der Volkslitteratur der türkischen Stämme Süd-Sibiriens [Samples of folk literature of the Turkic nationalities of southern Siberia]. Vol. 1-10. Sankt Peterburg: Tipografiia Imperatorskoi Akademii nauk.

Radloff, Wilhelm. 1885. Der Dialect der Kara-Kirgisen [The dialect of the KaraKyrgyz]. Vol. 5 of Proben der Volkslitteratur der türkischen Stämme Süd-Sibiriens. Sankt Peterburg: Tipografiia Imperatorskoi Akademii nauk.

Radlov, Vasilii V. 1995a. "Obraztsy narodnoi literatury severnykh tiurkskikh plemen" [Samples of folk literature of northern Turkic tribes]. In Entsiklopedicheskii fenomen eposa "Manas" = Encyclopaedical Phenomenon of Epos "Manas," edited by S. Aliev, R. Sarypbekov and K. Matiev, 25-42. Bishkek: Glavnaia redaktsiia Kyrgyzskoi Entsiklopedii.

Radlov, Vasilii V. 1995b. "Samples of folk literature of northern Turkic tribes: Preface." In Entsiklopedicheskii fenomen eposa "Manas" = Encyclopaedical Phenomenon of Epos "Manas," edited by S. Aliev, R. Sarypbekov and K. Matiev, 254-75. Bishkek: Glavnaya redaktsiia Kyrgyzskoi Entsiklopedii.

Rakhmutallin, Kalim A. 1995. "Plot Pecularities of 'Manas' Versions." In Entsiklopedicheskii fenomen eposa "Manas" = Encyclopaedical Phenomenon of Epos "Manas," edited by S. Aliev, R. Sarypbekov and K. Matiev, 294-330. Bishkek: Glavnaia redaktsiia Kyrgyzskoi Entsiklopedii.

Reichl, Karl. 2016. "Oral Epics into the Twenty-First Century: The Case of the Kyrgyz Epic 'Manas."' The Journal of American Folklore 129 (513): 327-44. https://doi. org/10.5406/jamerfolk.129.513.0327

Ukudeeva, Jamilya. 2015. "Manas: Kyrgyz Folk Epic." In Censorship: A World Encyclopedia, edited by D. Jones, 1523. London, New York: Routledge.

Valikhanof, Chokan C., and Mikhail V. Veniukof. 1865. The Russians in Central Asia: Their Occupation of the Kirghiz Steppe and the Line of the Syr-Daria: Their 
Political Relations with Khiva, Bokhara, and Kokan: Also Descriptions of Chinese Turkestan and Dzungaria. London: E. Stanford.

Valikhanov, Chokan Ch. 1985. Sobranie sochinenii v piati tomakh. Vol. 3. Alma-Ata: AN Kaz. SSR. Vstrechi na granitsakh website. Accessed August 15, 2019. http:// meeting.nlrk.kz/result/ebook_48/index.html?txtPg $=350 \& \mathrm{cmdGo} . \mathrm{x}=0 \& \mathrm{cmdGo} . \mathrm{y}=0$ Wielecki, Kamil Maria. 2015a. "The Arrow Paradox: The Motion That Is Anthropological Cognition.” In Imagine There Were No Humanities... Transdisciplinary Perspectives, edited by I. Ackermann et. al., 69-77. Warszawa: Wydawnictwo DiG.

Wielecki, Kamil Maria. 2015b. "Tradycja i modernizacja: Wokół rosyjskich kolonializmów" [Tradition and modernization: Regarding Russian colonialisms]. In Syberia: Tradycja i modernizacja. Vol. 9 of Debaty Artes Liberales, edited by K. M. Wielecki, 5-22. Warszawa: Wydział "Artes Liberales."

Wikipedia, s.v. "Valikhanov, Chokan Chingisovich." Last modified April 24, 2019. https://ru.wikipedia.org/wiki/Валиханов,_Чокан_Чингисович

Wikipedia, s.v. "Epic of Manas.” Last modified September 2, 2019. https://en.wikipedia. org/wiki/Epic_of_Manas

Wikipedia, s.v. "Kasym Tynystanov." Last modified August 27, 2019. https://en. wikipedia.org/wiki/Kasym_Tynystanov 
II

\section{BUDDHIST IDENTITIES}




\title{
Darima Amogolonova
}

ORCID 0000-0002-1176-4095

Institute for Mongolian, Buddhist and Tibetan Studies,

Siberian Branch, Russian Academy of Sciences

\section{BUDDHISM AND ORTHODOXY \\ IN BURYATIA: \\ RELIGIOUS INTERACTION \\ IN THE CONTEXT \\ OF RUSSIAN IMPERIAL POLITICS}

\begin{abstract}
This paper deals with the problems of religious coexistence in late-imperial Russia based on the case of Buryatia. The only state religion - Russian Orthodoxy - saw its task in converting the non-Russians by all possible means and in shortest time. This policy coincided with the interests of the state, as religious homogenization was considered the most effective way to achieve the desired loyalty and patriotism among all subjects of the Empire. Buddhism, which according to the Orthodox clergy was a so-called foreign religion, presented a potential threat to the state, as its believers could be under influences from abroad. The author argues that the secular authorities both in St. Petersburg and in Eastern Siberia faced a dilemma that consisted in the necessity to conduct Russification among non-Russians and simultaneously to strengthen the borders of the Empire in the East. The Buryat subjects were officially allowed to confess Buddhism, since the authorities, being aware of danger from Qing China, needed a balanced policy towards them to avoid discontent and disturbances. Under such conditions, the Orthodox clergy, missionaries in particular, disregarding the damage their intolerance could cause to the state's interests, became opponents to Siberian
\end{abstract}




\section{Darima Amogolonova}

officials, accusing them of supporting Buddhism and Buddhist priesthood instead of rendering all possible assistance in the Christianization of non-Russians.

Keywords: Buryats, Buddhism, Orthodoxy, Christianization, Russian Empire, Russification, state identity, spiritual space

In 1741, Buddhism was officially recognized as one of the religions confessed by the subjects of the Russian Empire. The activities of the Buddhist clergy were under strict control of the Russian secular authorities. The numerous rules and restrictions received the most complete form in the Regulation on the Lamaic Clergy in Eastern Siberia (1853; henceforth the Regulation). The policy of the Empire towards Buddhism among Buryats, at least up to 1905, was of dual character: on the one hand, the state showed unceasing desire to limit the activities of the Buddhist clergy in order to prevent its influence on the non-Buddhist Buryat population living in areas to the west from Lake Baikal (Cisbaikalia). The political background for this lay in the idea that being a foreign religion, Buddhism posed a potential threat to the state due to the possible influence from foreign countries, Qing China in the first place. On the other hand, the existence of institutionalized Buddhism among Buryats testified to the tolerance of the Orthodox Empire towards the non-Christian population, and this was important from the point of view of Russia's developing interests in Central Asia. In these circumstances, the Buddhists were forced to maneuver to protect their rights to confess their own religion. Nikolai Tsyrempilov describes this as "looking at the Empire not as a hostile force, but as a field of opportunities and a sphere 
of symbiotic interaction" (Tsyrempilov 2014, 65), which the Buryats tried to achieve by means of making the Tsar and his ministers allies of the Buddhists (Tsyrempilov 2013, 205).

Simultaneously, the strategic aims of the state were rather evident: to Christianize, first, the Cisbaikalian (western) Buryats, who continued confessing shamanism and, second, the Transbaikalian (eastern) Buryats, who by the moment under study had been Buddhists for many generations. On this issue, the position of the secular authorities in Eastern Siberia was more or less liberal and consisted in careful and gradual work among the non-Christians who would be interested in converting to Orthodoxy. In any case, the Governor Generals of Eastern Siberia saw their task in controlling whether the Buddhist clergy followed the articles of the Regulation and in suppressing any actions that contradicted it.

The position of the Orthodox Church was rather different. Despite the fact that the Regulation was quite prohibitive, the leadership of the Irkutsk Eparchy and Orthodox missionaries believed that it was insufficient and too soft on the alien religion. In numerous reports to St. Petersburg, which looked like denunciations, the missionaries appealed to the state to resolve justly the problem of unequal conditions in which the Buddhist and Orthodox clergy operated. Christian missionaries named the obstacles to their activities: vastness of the space occupied by the indigenous population, wildness of nature, a huge number of "pagans" (some 225,000), and extreme shortage of missionaries, churches, and financial and material resources. But the biggest difficulty they saw in the activity of aboriginal lamaic clergy. 
From the missionaries' point of view, the injustice consisted in endowing Buddhist clergy with state-owned land, from 500 desiatinas (more than 500 ha) given to Bandido Lama to 15 desiatinas assigned to khuvaraks - datsan students. ${ }^{1}$

Moreover, they benefit from the considerable datsan incomes received from the apparently voluntary but actually forced offerings of the laity [and] from the sale of burkhans (pagan idols), spiritual paintings, prayers, belts and household supplies. The datsans are also endowed abundantly with state-owned land. In general, the Lamaic clergy, its datsans and idols are quite well off financially, while Orthodox missionaries, except for their meager salaries, have nothing, neither from the government, nor from their parishioners (Pravoslavnaia missiia).

At the same time, the report notes that, "for their service, harmful though it is to the benefit and integrity of the state, all Lamaic clergymen are spared from all duties, both of the state and public ... and are completely free from the supervision of civil authorities" (Pravoslavnaia missiia). Besides, the missionaries complained that the privileged position of the lamas was further supported by the fact that the head of their community, the Hambo Lama, was confirmed in his title by the SovereignEmperor and "receive[d] a sealed letter of honor," thus acquiring in the eyes of the native population (the inorodets) "a moral force against which no missionary can present anything of equal import" (Pravoslavnaia missiia).

From St. Petersburg, this report was sent back to the Governor General of Eastern Siberia Mikhail Korsakov, who did not pay

\footnotetext{
${ }^{1}$ In reality, the Orthodox missions were not deprived. For example, according to a Barguzin Buryat chronicle, in 1886, in the Barguzin area alone, two missionary camps received from the government 110 desiatinas of land (Vostrikov and Poppe 1935, 36).
} 
attention to the complaints concerning severe climate or the very existence of Buddhist believers and their clergy, but answered in detail on all essential points of the report, thus showing his deep knowledge of the situation.

In particular, Mikhail Korsakov explained the necessity for Hambo Lama to receive the highest approval of the Emperor to take his position. Before that, the official remarked, Hambo Lamas had received such permission from the Dalai Lama. Ever since instead of the Dalai Lama, the appointment began to come from the Russian Tsar, the Russian law was regarded as indisputable and therefore no Hambo Lamas appealed to the Dalai Lama. Thus, the prohibition, written into the Regulation, from having relations with foreign clergy was fulfilled. Concerning the allegedly prosperous position of the lamahood, the Governor General explained that the demand of the missionaries to "establish a tax on various fees charged by the Lamaic clergy from laymen for performing pagan rituals and for selling various Buddhist spiritual accessories of their superstitions, like the burkhans (statues), spiritual pictures, prayers, belts, etc." was excessive, for such activity corresponded with the Regulation, which allowed "voluntary, by no means a forced payment (§ 47). The sale of burkhans, images, prayers, belts, and other church items is based on the price-list, which is compiled annually by the Bandido Khamba and approved by the Military Governor of the Transbaikalian Region (§ 55)" (Pravoslavnaia missiia). However, if the lamas insisted on some additional payments, coercion of this kind could be only of moral character and could hardly be averted by taxes. 
As for the prohibited but occurring contacts of Buryats with the Buddhist priesthood abroad, Mikhail Korsakov was of the opinion that this could not be viewed as a violation of laws or as treason. Being by all means a person who faithfully served the Emperor and the Russian Empire, he was devoted to the Orthodoxy that was the only state religion, and like most government officials, he saw the usefulness of converting Buryats to Orthodoxy as a means of promoting civilization and loyalty to the Empire. At the same time, he understood the necessity of dialogue with the "others" who confessed non-Christian religions. For this reason, he thought, the spirit of the law, the Regulation in particular, was more 140 important than its letter. His good knowledge of Buryat spiritual and everyday life prompted him to express his point of view on the prohibition to the Buddhist clergy from making pilgrimages to Tibet and Mongolia. Such trips, if discovered, could bring about deprivation of the monastic status and demotion to the secular state, exile to the most distant areas of Eastern Siberia, or punishment that was even more radical. Nevertheless, such practices could not be completely eradicated for the reason that "the worship of the Dalai Lama, the god in the guise of man, who descended to the earth to observe the people living on it, is one of the main tenets of the Buddhist teachings" (Pravoslavnaia missiia). Various restrictions and punishments up to penal battalions could not turn Buddhists away from religious pilgrimage. Intimidation was thus pointless; moreover, it brought about resentment and distrust towards ethnic Russians. 
To please the Orthodox clergymen and to refocus their attention from Buddhism to the issues more urgent to them, Korsakov proposed other measures to reduce the importance of Buddhism among Buryats. He suggested creating more favorable financial conditions for the missionaries in Siberia, thus providing proof of their personal superiority that would promote the undoubted verity of their preaching: "this will guarantee the success of their work better than any police measures" (Pravoslavnaia missiia).

Of course, Mikhail Korsakov was not alone in his ideas about Buddhism among Buryats and about the necessity to stick to a gradual and cautious course in the homogenization of nonRussians and non-Christians with the ethnic Russians. Another prominent person of similarly liberal views was Prince Esper Ukhtomskii, who was a high-ranking official at the Ministry of Foreign Affairs, a diplomat, an outstanding specialist in Mongolian studies, a supporter of Eurasianism, and a personal friend of Buryats, especially monks. In 1886, Ukhtomskii was sent on behalf of the Department of Foreign Confessions at the Ministry of Foreign Affairs to the territory inhabited by Buddhist Buryats. His instructions were to find out how the Regulation was being enacted by the lamas and the Buryat population (since, according to Orthodox missionaries, the Regulation was not observed), to identify damage to the Buryat economy caused by Lamaism, to determine the feasibility of the activities proposed by the Orthodox mission to suppress the spread of Lamaism, and to present his own views on what changes or additions should be made to the Regulation of 1853, which was being called obsolete (Vostrikov and Poppe 1935, 19). 
Esper Ukhtomskii's Report (and even its title, An Essay on the Development of Lamaism in the Eastern Siberian Frontier and the Most Appropriate Tool for Combating It) was fully consistent with the goals presented by the missionaries: to find out "how and why lamas have come to have a strong influence in the country, and also how to counteract it gradually, without resorting to drastic measures but on the contrary, by skillfully using their own unreasonable desires and weaknesses" (Tsyrempilov 2011, 167 [document 6.1, 87]). Ukhtomskii notes that in having nationalized and promoted the growth of the Buddhist church, the authorities made a mistake that significantly strengthened the position of Buddhism among Buryats. The expansion 142 of the social base of Buddhism was thus due to activities aimed at eradicating shamanism. While it was initially thought that the shamanists would become the bulk of new Orthodoxy Christians, in reality, the western (Cisbaikalian) shamanist Buryats were quite receptive to Buddhism, even if they had previously been baptized. Those who performed the task of baptism saw the reason for this in the fact that the Buryats who converted to Orthodoxy did not really become Christians: "most of them know Christianity only by name" (Otchet Irkutskogo episkopa). The Buddhist clergy who fought for the minds of shamanists were described in Ukhtomskii's Report in the following words:

Lamas wander around the Irkutsk province, teach their fellow tribesmen to worship the Buddha, and bring something fantastic to the painful monotony of the inorodets life. The limits of a harmoniously organized pagan kingdom are imperceptibly expanding. Based on the reports of the local Orthodox priests, it is easy to judge how quickly Buddhism has been growing among those who were torn away from shamanism. 
Unfortunately, the newly baptized Buryats, according to the testimony of the missionaries themselves, are not rigid in belief and often succumb to the temptation to raise their children completely outside of Christianity. Lamaic talismans often hang on cradles; Lamaic idols are kept in their dwellings, etc. The shamanizing Buryats are inclined to sympathize with Buddhism also because it allows them to remain Buryats and does not stipulate, like Orthodoxy, merging and identifying with the Russian nationality (Tsyrempilov 2011, 182 [document 6.1, 105b-106]).

In this connection, it is worth noting that the shamanists would often resist succumbing not only to Christianization: their Buddhization was also not always successful and final. Returning to the confrontation between the Orthodox missions and the Buddhist clergy, Esper Ukhtomskii, having studied the situation with Buddhism among the Buryats, put forward his proposals regarding the possible amendments to the Regulation of 1853. Contrary to the expectations of Orthodox missionaries, these proposals, which were presented in a table opposite each paragraph of the existing Regulation, did not contain repressive and restrictive measures, but rather attempted to bring the letter of the law in line with existing practices. Concerning the number of religious centers that far exceeded those allowed by the Regulation, Esper Ukhtomskii proposed "not to impede their reproduction: the more numerous they are, the poorer each of them will become and more widespread will be the hatred between the learned lamas, a hatred we still artificially suppress and eradicate" (Tsyrempilov 2011, 244 [document $6.3,255])$. Thus, Esper Ukhtomskii believed that the internal competition between lamas would prevent them from uniting for the common goal of preserving and spreading Buddhism 
among the Buryat population, rendering the activity of Orthodox missions more successful.

Failures of the baptizing policy encouraged the Orthodox clergy to violate state regulations, which from the early 19th century on strictly banned forced baptizing. Ukhtomskii was fully convinced that any coercion in the Christianization of the inorodets was inadmissible. He criticized the Siberian Orthodox clergy who, when discussing the problem at the Irkutsk Congress of Siberian Bishops (1885), came to the conclusion that forced baptism was perfectly permissible. Simultaneously, the Congress recognized the unsatisfactory composition of the missionary corps and facts of "inappropriateness and harmfulness of their 144 behavior" (Ukhtomskii 1892, 7). In other words, the leaders of Orthodoxy understood that the root of the slow Christianization should be looked for not in Buddhism but in the missionaries, most of whom fulfilled their duties strictly formally, as if they were not interested in the results. Based on a document found in the Archive of the Holy Governing Synod (the governing body of the Russian Orthodox Church, composed of clergy and high-ranking lay officials, and answering to the Emperor), Esper Ukhtomskii claims that "the local archbishop exaggerates the number of the converted, and the missionaries are rude, drunk, ignorant, they burn and insult objects of the Buryat cult" (Ukhtomskii 1892, 7). Ukhtomskii gives a telling example that illustrates the behavior of the leaders of East Siberian Orthodoxy regarding unbaptized Buryats. When a group of them expressed a desire to study at their own expense at the teachers' seminary, they were denied in fulfilling their wish: 
If you don't accept them and deprive the Buryats in their completely natural and in every way desirable readiness to implement government goals at their own cost, leading to a gradual, painless Russification - the latter, of course, will not come soon, and equally far is the glorious day when East Siberian Lamaists will finally enter the bosom of the Church voluntarily and freely (Ukhtomskii 1892, 18).

This example characterizes the activities of the Orthodox clergy among and their attitude to the Buryats: at a time when the state was focusing on instilling Russian patriotic feelings and loyalty among the non-Russian subjects, the Orthodox clergy, in fact, openly discriminated against the unbaptized, thus violating Russian legislation and contributing to the growth of dissatisfaction with the Empire, and feeding anti-Russian sentiments among them.

In the $1890 \mathrm{~s}$, glaring facts about cruelty of forced baptisms became known to the public and caused an explosion of indignation among liberals. The baptizing campaign was timed to coincide with the arrival of Tsarevich Nikolai, who visited the Buryat territories in 1891. It was planned that he personally would baptize a number of pagans. Local authorities, both secular and clerical, decided to curry favor with the prince and for this reason organized baptizing of western Buryats who had by that moment become Buddhists (for details see: Amogolonova and Sodnompilova 2017).

Mass conversions to Buddhism among western Buryats, both Christians and shamanists, were not accidental at that time. The end of the 19th and the beginning of the 20th century was the time when Buryat ethnonational thought and political ideology emerged. The worldview of the Buryat leaders was 
formed under the influence of the general atmosphere in Russia. Their ideas of national and cultural awakening thus concentrated on historical memory and required a legacy whose role was to ensure Buryat integration and prevent Russification. The Buddhist religion was seen as one such channel of ethnic consolidation and revival. The efforts of the leaders, first of all Agvan Dorzhiev, to promote Buddhism among the Cisbaikalian shamanists and baptized Buryats proved successful. The ease with which these people left Christianity for Buddhism was caused by a number of reasons. First, their ideas about Orthodoxy were usually superficial and did not imply any deep belief. The lack of real work of missionaries with the 146 flock resulted in nearly complete ignorance among the new Christians of the religion they allegedly followed. Second, most priests and missionaries had no idea about Buryat culture, and especially language, and even if they wished to communicate with Buryats, they were not able to offer any explanations or answer any questions. Third, Buryats felt disrespect on the part of the Orthodox clergy and ethnic Russian parishioners towards their newly-baptized co-religionists (and especially towards the unbaptized population). Buryats, even those who mastered Russian culture and adopted Russian lifestyle, remained nevertheless "the others" and were treated as crude, uncivilized people, who did not deserve equal treatment. This indestructible racism as an element of Russian imperial consciousness was mainly built on Orthodoxy, which saw as its aim regarding Buryats "developing them civically and raising the level of moral concepts among them" (Pravoslavnaia missiia). 
The final fiasco of Orthodoxy among Buryats was associated with the publication of the Emperor's Supreme Decree to the Senate on Strengthening the Principles of Tolerance (April 17, 1905), ${ }^{2}$ which gave the Buryats legal right to reject Orthodoxy and transit en masse to Buddhism.

The Supreme Decree, which was included into the Code of Russian Laws, would seem to imply that no one had the right to obstruct the procedure of leaving the Orthodox religion for any other. In reality, however, the opposite proved to be the case when baptized Buryats who wanted to leave Orthodoxy declared Buddhism as their new religion. Methodius, the bishop of Transbaikalia and Nerchinsk, found in the Decree the words that, in his opinion, made it possible to refuse them their right to be excluded from Orthodoxy: "profess the non-Christian faith to which they themselves or their ancestors belonged before Orthodoxy" (Polnoe sobranie 1908, 257). In his report to the Synod, the bishop pointed out that in the Transbaikalian Eparchy, "non-Russians do not know well enough or do not know at all the creed (usually Buddhism) they wish to fall into, and through this, I think, these individuals can be treated as those who in fact do not profess and have not professed the faith which they intend to join" (Po arkhivu). The bishop included in the category former shamanists who nevertheless wanted to become Buddhists - which, in his opinion, contradicted the letter of the Decree, since they and their ancestors had not been

2 "[P] ersons who are on the list of Orthodox Christians, but who in fact profess the nonChristian faith to which they themselves or their ancestors belonged before Orthodoxy, are subject to their exclusion from the Orthodoxy should they so wish" (Polnoe sobranie 1908, 257). 
Buddhists - as well as those who did not know the Buddhist religion well enough or did not know it at all, and those who renounced Orthodoxy under the pressure from other people. In addition, the bishop claimed that collective decisions to reject Orthodoxy at the gatherings occurred in violation of the rules, for example when the participants (men only) were in insufficient numbers (less than 2/3 of adult men) and the votes of women and those men who had no right to participate in the gathering were counted (Po arkhivu).

Complaining that the Governor's order on the implementation of the Decree within a month could not be fulfilled, the bishop by force of habit mentions absence of money for the mis148 sionaries' travel expenses, their lack of knowledge of the Buryat language to persuade the inorodets to remain in Orthodoxy, and a shortage of qualified translators. The bishop notes that in a number of cases the Spiritual Consistory found it possible to deny the Buryats in their wish to transit from Orthodoxy to Buddhism even when it was established by police inquiries that they themselves or their ancestors had previously practiced Buddhism. The following circumstances served as the basis for the refusal: ignorance in the Buddhist creed; living in the Buddhist environment and therefore being under external influence; constant performance of Orthodox rites by these Buryats; birth from Orthodox parents and baptism in childhood; living away from Orthodox clergy and therefore lacking the possibility of receiving Christian spiritual admonition (Po arkhivu).

One can see that Methodius did his best to drag out bureaucratic delays. But head (Chief Procurator) of the Synod 
Sergei Luk'ianov stood on more realistic positions: he offered to make admonitions to those who fell away from the Church but at the same time not to obstruct those who were Orthodox "by name only" or who themselves or whose ancestors really belonged to a non-Christian religion, which the applicant confessed at the moment of application, as "they are the Orthodox only formally, as if mistakenly, while in reality ... they continuously profess a non-Christian religion" (Po arkhivu). Moreover, anticipating further bureaucratic delays, the Chief Procurator explained that the applications for withdrawal from Orthodoxy fell entirely under the competence of civil authorities and therefore were out of the jurisdiction of the eparchies (Po arkhivu).

Hieromonk Aleksii, a teacher at the Tomsk Theological Seminary, used the following words tu sum up this new policy regarding the non-Russian Orthodox population in Siberia, baptized Buryats in particular:

We have the offspring of Mongols here in our lands; they make up the indigenous population of Siberia. A significant part of this population has not yet been enlightened by the light of the Christian faith, and the other part, although it is considered baptized, in faith and life differs little from the pagans.... And here the Orthodox priesthood wanted to instill Christianity in non-Russians in a language alien to them, without resorting to their national means. As a result, we can see among the inorodets a lack of understanding of the Christian faith and even a desire to return from Christianity to paganism. First of all, this should be said about the Buryats living in the Irkutsk and Transbaikalian Eparchies.... The non-Russians, in fact, do not know the Christian faith, the baptized ones believe and live like pagans, and to make things worse, under the influence of agitation and the freedom granted to them in matters of faith, they rushed back to paganism (Aleksii 1910, 18). 
Thus, the Supreme Decree on Strengthening the Principles of Tolerance made it evident that the baptizing policy among Buryats proved ineffective: in most cases, Christianization was formal, the baptized Cisbaikalian Buryats remained shamanists and the Transbaikalian Buryats remained Buddhists. Both groups, under the influence of the successfully spreading Buryat national ideology, preferred Buddhism to Christianity. In this regard, it will be fair to conclude that the instrumental approach of the state to Orthodoxy as a conductor of Russification and Russian identity turned out to be untenable for various reasons, among which the insufficient qualifications of the Christian preachers were not the most significant. More importantly, the Orthodox leadership and missionaries did not recognize that non-Russians, Buryats in particular, possessed their own culture and a developed religious worldview. Therefore, the Buryats were considered as savages, who were easy to persuade, intimidate or bribe. This could not but cause a negative reaction on the part of the converts, for whom Orthodoxy became nothing more than a way to achieve their own pragmatic goals. Nevertheless, the state goals of strengthening the borders by educating the non-Russian subjects in the spirit of devotion to the Tsar and the Empire were fulfilled. A significant role in this process was played by institutionalized Buddhism, which entered the Russian socio-political structure and contributed to the Russian state identity of Buryats. 


\section{BUDDHISM AND ORTHODOXY IN BURYATIA...}

\section{WORKS CITED}

Aleksii, ieromonakh. 1910. Irkutskii Missionerskii S"'ezd (24 iiulia - 5 avg. 1910 g.): Dnevnik uchastnika s"ezda [Irkutsk Missionary Congress (July 24 - Aug. 5, 1910): Diary of a congress participant]. Tomsk: Tip. Priiuta i Doma Trudoliubiia \& Izd. Soveta Bratstva Sviatitelia Dimitriia.

Amogolonova, Darima D., and Marina M. Sodnompilova. 2017. "Religiia i identichnost' v Buriatii: Konkurentsiia pravoslaviia i buddizma v pozdneimperskii period (na materialakh sankt-peterburgskikh arkhivov)" [Religion and identity in Buryatia: The competition between Orthodoxy and Buddhism in the late imperial period (materials from the St. Petersburg archives)]. Gosudarstvo, religiia, Tserkov' $v$ Rossii i za rubezhom 35 (2): 241-63.

Otchet Irkutskogo episkopa o sostoianii Irk. Eparkhii za 1861 g. s dannymi o deiatel'nosti missionerov [Report of the Irkutsk bishop on the state of Irk. Eparchy in 1861 with data on the activities of missionaries]. RGIA (Russian State Historical Archive, St. Petersburg), f. 796, op. 442, d. 51.

Po arkhivu Sviateishego Pravitel'stvuiushchego Sinoda [In the archives of the Holy Governing Synod]. RGIA, f. 796, op. 189, d. 8494.

Polnoe sobranie zakonov Rossiiskoi Imperii: Sobranie tretie [Complete collection of laws of the Russian Empire: Collection three]. 1908. Vol. 25, 1905 god, part 1. Sankt-Peterburg: Gosudarstvennaia tipografiia.

Pravoslavnaia missiia sredi inorodtsev-iazychnikov v Sibiri i mery protiv propagandy lamaiskogo dukhovenstva (1866-1898) [The Orthodox mission among pagan non-Russians in Siberia and measures against the propaganda of the Lamaic clergy (1866-1898)]. RGIA, f. 821, op. 133, d. 431.

Tsyrempilov, Nikolai V., ed. 2011. Materialy po istorii buddizma v Zabaikal'e XIX$n a c h . X X v v$. [Materials on the history of Buddhism in Transbaikalia in 19th to early 20th centuries]. Ulan-Ude, Sankt Peterburg: IMBT SO RAN. Tsentr vostochnykh rukopisei i ksilografov IMBT SO RAN website. Accessed August 6, 2018. https:// web.archive.org/web/20180806215352/http://imbtarchive.ru:80/index.php?topic=10

Tsyrempilov, Nikolai V. 2013. Buddizm i Imperiia: Buriatskaia buddiiskaia obshchina $v$ Rossii (XVIII-nach. XX v.) [Buddhism and Empire: Buryat Buddhist community in Russia (18th to early 20th centuries)]. Ulan-Ude: IMBT SO RAN.

Tsyrempilov, Nikolai V. 2014. "Buddizm i rossiiskoe gosudarstvo v 19 veke: Ot konfliktov k kompromissam" [Buddhism and the Russian state in the 19th century: From conflicts to compromises]. In Buddizm v istorii $i$ kul'ture buryat, edited by I. R. Garri, 36-65. Ulan-Ude: Buriaad-Mongol Nom.

Ukhtomskii, Esper E. 1892. O sostoianii missionerskogo voprosa v Zabaikal'e [On the missionary issue in Transbaikalia]. Sankt-Peterburg: Sinodal'naia tipografiia.

Vostrikov, Andrei I., and Nikolai N. Poppe. 1935. Letopis' barguzinskikh buriat: Teksty $i$ issledovaniia [Chronicle of the Barguzin Buryats: Texts and studies]. Moskva, Leningrad: Izdatel'stvo Akademii nauk SSSR. 


\title{
Bato Dondukov
}

ORCID 0000-0001-5501-9858

East-Siberia State University of Technology and Management

\section{ELECTRONIC PETITIONS \\ OF RUSSIAN BUDDHISTS: \\ A WAY OF CONSOLIDATION \\ OR ESTRANGEMENT?}

\begin{abstract}
The article is devoted to the analysis of two electronic petitions created by Russian Buddhists, one protesting the deportation of the Buddhist teacher Shivalkha Rinpoche, the other protesting so-called Buddha Bars throughout Russia. These two causes reflect to some extent the current relationships between different categories of Buddhists, such as the clergy and laymen or traditional and modern Buddhists. The article studies reactions of different communities to these problems and traces differences in Buddhist identifications, as well as the positive or negative impact these reactions have on the consolidation of Buddhists. Finally, I evaluate the efficiency and prospects of e-petitions as a problem-solving method for Buddhists in Russia.
\end{abstract}

Keywords: Buddhist communities of Russia, crowdsourcing, electronic petitions, consolidation of Buddhists, Buddha Bars, Shivalkha Rinpoche, religious identity

Nowadays, electronic petitions have become a popular way of solving societal problems. Over the last few years, the Buddhists of Russia have started to use this channel in pursuit 


\section{Bato Dondukov}

of their interests, too. However, their case is quite peculiar. First of all, it is necessary to bear in mind that they are rather decentralized in institutional terms and represent Buddhist communities that belong not only to different Buddhist schools but also different types of Buddhism, both traditional and modern. While the traditional Buddhism of Russia became spread among the Buryats, Kalmyks and Tuvinians more than 300 years ago, the modern Buddhism is mainly represented in the central regions of Russia in the form of dharma centers, which became widespread only at the end of the 20th century. What is more, it is necessary to make a distinction between two categories of believers: the monks - who belong to monastic 154 communities (sangha), represented by institutions of internal hierarchy and certain authority - and laymen, who traditionally address a sangha in order to fulfill their spiritual needs. Taking into account that the e-petitions analyzed in the article appeal to the federal government, in this article I aim to trace interrelations between not only various schools of Buddhism but also traditional and modern Buddhists, monks and laymen, as well as between the Buddhist clergy and different levels of Russian government. I try to determine who specifically wants to attract the government's attention to the problems of Buddhists, what the position of the clergy and laymen is in regard to this situation, whether petitions represent a typical way of solving problems among Buddhists of Russia, and how effective e-petitioning proves. These answers will help to establish whether e-petitions tend to unite or alienate different sections of the diverse group that are the Russian Buddhists. 
I will analyze the hitherto only two cases of e-petitioning being used by the Buddhists of Russia: one concerned the deportation of the Buddhist teacher Shivalkha Rinpoche, the other protested the opening of so-called "Buddha Bars" in Russia.

At the outset, it is necessary to briefly characterize the variety of Russian Buddhism. Though nowadays almost all traditions and schools of Buddhism, such as Mahayana (Tibetan and Far Eastern Buddhism) and Theravada (Southern Buddhism), are represented in the country, they developed in different periods, which is reflected in the distinction between traditional and modern Buddhism. Traditional Buddhism is represented by the regions of Buryatia, Kalmykia and Tuva, where Tibetan Buddhism of the Gelug school was practiced by the local populations even before they merged into the Russian state. The Buddhism there is characterized by a system of monastic institutions and temples as well as a lineage of spiritual leaders. In other regions of Russia, Buddhism spread much later and mainly in the form of dharma centers. These communities belong to other Buddhist traditions and schools, and are usually organized around visiting Buddhist teachers (Nesterkin 2008, 46). This is a western type of Buddhism, and scholars usually define it either as "modern Buddhism" (McMahan 2008, 9), "secular Buddhism" (Higgins 2012), or "neo-Buddhism" (Agadzhanian 2008).

The laymen and their practices differ greatly between traditional and modern Buddhism. First of all, the Buddhist identity is usually formed on a different basis among traditional Buddhists than it is among non-traditional ones. The former are born 


\section{Bato Dondukov}

Buddhists, while the latter make a conscious choice regarding their religious identity (Agadzhanian 2008, 862). What is more, various cults of deities, temples, and even Buddhist teachers are of sacral significance in traditional regions. Numerous folk rituals, worships, and offerings are performed and supported by the Buddhist institutions in these areas. It is also important to note that Buddhist institutions in Buryatia, Kalmykia and Tuva have always enjoyed high authority among the local people and played a big role in the history of these ethnic groups, including their relations with the center (Tsyrempilov 2013).

The roots of the modern Buddhism, in turn, lie in what can be called new religious movements (cf. Barker 1989) - a current 156 of movements searching for new, non-Christian religious ideas, which arose in the West in the mid-20th century. The associated image of Buddhism was formed by a discourse of the orientalists and of the Buddhist leaders who were engaged in adaptation and even simplification of traditional Buddhism for the sake of western societies (McMahan 2008). As a result, for neophytes, Buddhism is mainly connected to personal development and meditations, which is why they mostly focus on Buddhist theory and methods. They "tend to reject the ritual practices of Buddhism widespread in traditional regions" (Agadzhanian 2008,862 ), and at the same time do not always have strong ties to a certain community, as in traditional Buddhism. What is more, they feel free to modify the doctrine to fit their needs: they can choose suitable elements from the Buddhist tradition and reject undesirable ones. As Bernard Faure comments, it is a re-adaptation, "a kind of Buddhism à la carte" that is 
reformulated to "fill a void in the West," rather than reflect the ancient canons and secondary literature of Buddhism (Faure 2011, 139-41).

Speaking about the variety and non-centralization of Buddhism in Russia, one should also note the difficult relations of Buddhist leaders within various traditional Buddhist organizations. Thus, the Traditional Buddhist Sangha of Russia (BTSR), in spite of belonging to Tibetan Buddhism, stays detached from the activities of other Tibetan Buddhists. Damba Aiusheev, the leader (Hambo Lama) of the BTSR, which represents Buryatian Buddhism, criticizes non-BTSR Buddhist teachers, including Tibetan religious leaders in Russia. He calls their activities aimed at promoting modern forms of Buddhism "kiosks for spreading religious services" (Garri 2014, 164). Yet in some other parts of Russia the situation is quite contrary. For example, the leader of Kalmyk Buddhists is Telo Tulku Rinpoche, a pupil of the Dalai Lama and one of his official representatives in Russia, whose actions correspond to the Tibetan line.

This variety and lack of unity among Buddhist communities in Russia render virtually impossible any consolidation or joint actions. On the other hand, however, the associated lack of uniform platform for interaction of Buddhists provides reasons for turning to Internet-based solutions, such as crowdsourcing. Daren Brabham in his book devoted to this phenomenon (Brabham 2013) traces the birth of this term back to June 2006, when Jeff Howe, the editor of the Wired magazine, introduced it in his article "The Rise of Crowdsourcing" (Howe 2006). 


\section{Bato Dondukov}

The term gained instant popularity, which actually led to a number of "misguided voices" spreading a confusing message about what exactly crowdsourcing was. Brabham himself defines crowdsourcing as

an online, distributed problem-solving and production model that leverages the collective intelligence of online communities to serve specific organizational goals. Online communities, also called crowds, are given the opportunity to respond to crowdsourcing activities promoted by the organization, and they are motivated to respond for a variety of reasons (Brabham 2013, XIX).

Initially applied in the creative and design industries, crowdsourcing is increasingly employed as a tool of social and political activity, including civic engagement and electronic democracy (Macintosh 2004), most notably through electronic petitions, formal online requests to higher authorities, which can be signed by multiple citizens. The most popular e-petition platform at the time of writing these words is change.org. Established in the USA in 2007 and quickly developed in other countries, according to the data published during my research, it boasted more than 100 million participants from 196 countries engaged in "the world platform of changes" (as the company called itself), and over 24,000 victories (Change.org n.d.).

One of the places where change.org has enjoyed growing popularity has been Russia. In 2013, a decree was even issued by the President of Russia Vladimir Putin which established the rules for the consideration of e-petitions (Ukaz 2013). It says that for an e-petition to be proceeded at the federal level, it is necessary to collect more than 100,000 signatures 
within a year, with regional level requiring signatures of 5\% of the region's population. The provisions of the 2013 decree define the legal conditions of e-petitions' potential success, and by doing so, set the scene for particular Internet-pursued causes. In the context of this research, it is necessary to mention the statistics concerning the quantity of Buddhists in Russia. While I did not manage to find up-to-date information, the data of 2005 presented by Russian religious scholars Sergei Filatov and Roman Lunkin states that there were about 900,000 ethnic Buddhists in Russia and about 500,000 non-ethnic ones (Filatov and Lunkin 2005, 46-7). Such numbers hold promise of successful e-petitioning. Now let me proceed to the analysis of the first two cases of e-petitioning used by the Buddhists of Russia.

\section{SHIVALKHA RINPOCHE'S DEPORTATION}

Shivalkha Rinpoche (born 1967) is a Tibetan Buddhist teacher, recognized by His Holiness the 14th Dalai Lama as reincarnation of Geshe Lharampa ${ }^{1}$ Shivalkha, a Buryat lama who taught Buddhist philosophy in Lithang Gonchen Monastery in Lithang County of Tibet in the 1950s. Shivalkha Rinpoche first visited Russia in 2004 as the head of a group of monks from Drepung Gomang Monastery (Southern India). In 2007, Shivalkha Rinpoche received the degree of Geshe, doctor of

\footnotetext{
${ }^{1}$ Geshe Lharampa is the highest scholarly degree conferred within the traditional Tibetan monastic system in the Gelug school. The curriculum requires more that 15 years of intensive study.
} 


\section{Bato Dondukov}

Buddhist philosophy, in Drepung Gomang and was invited to the Republic of Tuva for full-time residence by three Tuvan Buddhist organizations - Enerel, Manjushri and Menla. An official invitation for Shivalkha Rinpoche was handed to His Holiness the 14th Dalai Lama in March 2008 by Sherigool Oorzhak, the former President of the Republic of Tuva. Since 2008, Shivalkha Rinpoche constantly lived in the Republic of Tuva and was engaged in local religious activity (Zhironkina 2015).

On September 23, 2015, the Federal Security Service of the Russian Federation demanded the expulsion of the religious leader. His Russian residence permit was revoked, and he and his aide, monk Lobsang Tsering, were ordered to leave the 160 territory of Russia within 15 days and never to return again (Russia Religion News 2015). The decision was based on Article 25.10 of the Federal Law "On the Procedure for Leaving the Russian Federation and Entry into the Russian Federation." According to it, a person may be deported from the country if he or she constitutes "a threat to the defense capability or security of the state, to the public order, or to the health of the population," and also "in order to protect the foundations of the constitutional order, morality, and rights and legal interests of other persons" (Federal'nyi zakon 1996). Due to a regulation on the nondisclosure of national security information, the actual reasons of such decision remained unknown.

Shivalkha Rinpoche had a lot of followers in the Republic of Tuva and in other regions of Russia, and the authorities' decision to deport him from the country provoked a great resonance. His followers tried to solve the issue by legal means. 


\section{ELECTRONIC PETITIONS OF RUSSIAN BUDDHISTS...}

At the same time, they also initiated collection of signatures under a petition to President Vladimir Putin, the Minister of Defense Sergei Shoigu, ${ }^{2}$ and the Director of the Federal Security Service (FSB) Aleksandr Bortnikov, demanding reversal of this decision on behalf of the Buddhists of Tuva.

Meanwhile, the Buddhist Internet users started to broadly share information about the problem in the Buddhist communities in social networks in order to encourage other users to act. An administrator of one of the largest groups on Tibetan Buddhism in the social network VKontakte wrote an appeal to followers of the group on September 26, 2015:

Dear fellow Buddhist citizens, comrades, odnodkharmchane. Let's leave the legal matters to lawyers, and do what depends on us... And as fast as we can.

It is necessary to create petitions on change.org and on paper.

1. To formulate accurately and concisely a petition request, to specify the merits of the Honorable Lama and emphasize that without him, things will be worse.

2. To commence the signing on change.org

3. To send the petition link to all the key people.

4. To prepare a file with petition in .doc format and attach it to the page with the link to change.org. To include in the file, besides the text of petition, the mailing address for sending the paper version.

5. Consequently - the receiving side should be ready to handle this incoming mail.

6. All links and files should be sent to administrators of the groups: http://vk.com/club26370 http://vk.com/club53269

7. It is necessary to do all this quickly, time is slipping away. If we don't do it - there will be no turning back.

That's all, let's get down to work (Link 1 2015).

${ }^{2}$ Sergei Shoigu was born in the Republic of Tuva, and being the Minister of Defense of the Russian Federation can be considered the highest-ranking Tuvinian. 
This message of the administrator of the "Tibetan Buddhism" community in Vkontakte is a vivid example of the shifting of religious authority online. While the official Buddhist institutions stay aside, new leaders of the Russian Buddhist world start to arise in the online space. They usually attain influence thanks to their profound knowledge of Buddhist doctrine. The users begin to address them seeking answers to their questions: that is the way many of them become the administrators of groups and further, as in the example above, start to unite masses of users and induce them to specific action independently from the official religious authorities - "if we don't do it - there will be no turning back." The rhetoric of the administrator 162 of this online community is almost military. Sentences are short and sharp and communicate step-by-step instructions. Another militant feature is the neologism "odnodkharmchane," which is instantly recognizable as a combination of two words: odnopolchane "comrades-in-arms" and dkharma "dharma." It clearly denotes Buddhists united to fight for a common cause, and can be translated into English as "comrades-in-dharma."

The reaction to this message was immediate. First of all, the Internet users proposed to sign the written appeal on behalf of not only Tuvinian people, but of all Buddhists of Russia. At the same time, another petition on change.org - already on behalf of the Buddhists of Russia - was created seeking to "cancel the decision of the Federal Security Service of the Russian Federation on the undesirability of stay (residence) of Lobsang Gele (Honorable Shivalkha Rinpoche) and his assistant Lobsang Tsering on the territory of the Russian Federation" 
(Change.org 2015). The petition received 2,736 signatures. However, none of the abovementioned actions brought success and in October 2015 Shivalkha Rinpoche left Russia.

This electronic petition showed a certain consolidation of Buddhist online communities. Internet interaction brought together not only Shivalkha Rinpoche's students, but also representatives of many other Buddhists groups. Members of opposing Buddhist communities that do not share the views of Mahayana Buddhism in fundamental questions, and sometimes express this in a rather conflictual form, also participated in the distribution of the electronic petition. Thus, the official group of the Theravada.ru community reposted announcements about collecting signatures under the petition (Link 2 2015), even though its members had repeatedly distributed antiMahayana content, which in fact led to a conflict at the level of Thai Sangha of Theravada Buddhism (Dondukov 2015). Followers of this community, including its leader, monk Oleg Onoprienko (also known as Topper Pannyaavudho) reposted the petition, as well (Link 3 2015). Even though Theravada Buddhists were not interested in the development of Mahayana Buddhism in Russia, they showed solidarity with the Tibetan Buddhist teacher. The reasons for such support lay probably in the fact that this community also invited visiting Buddhist teachers and such governmental decision could later affect their activities, too.

As for the reaction to petition from the official Buddhist organizations of Russia, they either stayed silent or commented on the problem in a neutral manner. The only comments were 


\section{Bato Dondukov}

made by people who, like Shivalkha Rinpoche, were representatives of the Dalai Lama in Russia and contained only expressions of grief concerning the situation but did not encourage any actions on the part of the faithful. The Russian-born Buddhist leaders, such as Hambo Lama Damba Aiusheev (the leader of the BTSR) or Kamby Lama Lopsan Chamzy (the leader of the Association of Buddhists of Tuva), did not comment on this issue. Taking into account the Hambo Lama's views on visiting Tibetan teachers, which I have described above, the reasons for his silence are quite clear; the motives of Kamby Lama remain unknown. Public confrontation with political authorities might have been deemed too serious a step, one which could worsen 164 the sangha's political position and still bring no results. In any case, appeals of Internet users did not manage to go beyond the online space and the petition remained distributed among Buddhist Internet users only. Considering that the amount of followers of Buddhist groups in social networks is estimated in hundreds of thousands - which is much more than the 2,736 people who signed the petition - this case showed that the number of active Buddhist Internet users is actually very small. With no support from influential Buddhist figures offline, the campaign proved weak and failed to involve broad masses of Buddhists.

\section{BUDDHA BARS}

Another online protest campaign among the Russian Buddhists was associated with the so-called Buddha Bars that started to 
open in Russian cities in 2012. Buddha Bar is a bar-restaurant franchise created by French-Romanian restaurateur Raymond Visan and DJ and interior designer Claude Challe. The first Buddha Bar opened in Paris in 1996. "Buddha Bar was devised as an upscale bar-restaurant with an oriental 'lounge' ambience, and soon became a reference among foreign yuppies and wealthy tourists visiting the city" (D'Andrea 2007, 93). The brand quickly developed into a network of restaurants opening worldwide, including Marrakech, Beirut, Budapest, Dubai, London, and New York. The restaurants' use of Buddha as a popular icon was soon noted to be offensive to Buddhists. In 2010, there was a controversy around Buddha Bar in Jakarta, Indonesia, which drew protests from Buddhists claiming that the use of their religious symbols in a venue serving alcohol was an affront to their religion (Schonhardt 2013). The Jakarta location was closed by a court order later that year. As for Russia, a Buddha Bar restaurant opened in St. Petersburg in 2012 and in 2015 - another one in Moscow. The restaurants were especially notable due to their entertaining events in the format of shows with "go-go" dances that - judging by the photos posted on the official websites (Buddha Bar St. Petersburg n.d.) - happened around a big statue of Buddha. The high popularity of these restaurants provoked a certain vogue for Buddha Bars and resulted in an expansion of the chain into other Russian cities.

On July 26, 2016, Valeriia Sanzhieva, a female resident of Buryatia, created a change.org petition entitled "Ban Buddha Bars in Russia!," which was addressed to such authorities as Prosecutor General of the Russian Federation, the State Duma of 
the Russian Federation, the Ministry of Culture of the Russian Federation and also to the Russian President. She motivated her protest as follows:

It has come to our attention that in Moscow, St. Petersburg, Yakutsk, Rostov, Orenburg, Tyumen, Taganrog, Krasnoyarsk, Novokuznetsk, Shakhty and other cities of Russia, night clubs, bars and restaurants called "Buddha Bar," "Buddha Karaoke Bar," etc. are being opened. Statues and images of Buddha are located at the center of night clubs and restaurants, people take pictures with them, naked women use Buddha's statues as objects in go-go dances, touching them with uncovered body parts, alcoholic drinks are served and consumed in the clubs. These institutions openly spread photo and video content on the Internet, urge drinking, singing, entertainment, they organize pajama parties, alcohol and hookah parties, entertainment shows. Such attitude towards the Buddhist religion and ancient philosophical tradition is in gross and inadmissible violation of the rights and feelings of believers throughout Russia (Change.org 2016).

As Valeriia Sanzhieva noticed in personal communication, even though the petition was created on behalf of all Buddhists of Russia, it actually mattered only for Buddhists from Buryatia, Kalmykia and Tuva (Valeriya Sanzhieva, Vkontakte message to author, November 23, 2017). In comparison with the previous petition, this one concerned a problem that mainly touched interests of traditional Buddhists, who have a sacral attitude towards Buddhist objects and symbols (Mongush and Mongush 2015).

As I have mentioned above, traditionally Buddhist regions are rich in sacral objects and places. The local people regularly perform religious practices connected to these objects, such as rituals and offerings with the aim of purification from negative karma and accumulation of positive one. In other words, it is possible to assume that the feelings which were insulted by Buddha Bars are the product of traditional Buddhist regions in 
that they were formed by the local Buddhist institutions and acquired by the local faithful from childhood. While writing this article, I as a Buryat also felt negative emotions towards Buddha Bars. Having been brought up in an ordinary Buddhist family, I have regularly visited sacred places and temples from a very young age. During these visits, adults strictly controlled the proper behavior of children. For example, before entering a temple, it was always necessary to take off one's hat and inside the temple it was forbidden to speak loudly. You needed to approach and bow before all representations of Buddha and deities at the main altar, making offerings of coins that were given to you beforehand by adults. You prayed for all living beings to achieve freedom from suffering, or for help for a specific person in case of trouble. It was essential that when moving clockwise around the temple, you could not turn your back to the statues and images of deities. In the same manner, when at a khural (prayer service), it was forbidden to sit with one leg over the other, or to stretch legs in the direction of the altar or monks. Even at home, it was forbidden to misbehave near the altar. Naturally, practices like these would have formed respectful attitudes toward Buddhist objects, and seeing them in such places as Buddha Bars caused cognitive dissonance among traditional Buddhists.

The analysis of commentaries in Vkontakte Buddhist groups showed that all traditional Buddhists without exception supported the struggle against Buddha Bars and expressed their negative attitude to these places as insulting their religious feelings. However, if the case of Shivalkha Rinpoche's deportation was assessed as unambiguously negative, the case of Buddha Bars 
caused heated discussions in online Buddhist communities. Some users did not see any threats to their religious feelings, and, moreover, expressed discontent towards the petition. According to Valeriia, such commentaries only hindered achieving the goal, as owners of Buddha Bars visited Buddhist Internet resources and having studied the commentaries, became confident that many Buddhists did not have anything against their businesses (Valeriia Sanzhieva, Vkontakte message to author, November $23,2017)$. I cite the most popular (most "liked") commentaries against the petition from the online communities "Ban Buddha Bars" and "Buddhism," the latter being one of the largest Buddhist online communities in Vkontakte. A young Russian woman writes:

On the one hand, it is not good to use [Buddhist symbols] ... And on the other hand, if something offends a Buddhist, then is he a true Buddhist? So I would refrain from signing ... Buddhists are free from hypocrisy, unlike Christians, so maybe it isn't necessary to act just like Milonov ${ }^{3}$ [multiple smiley emoticons] (Link 4 2016).

\section{A message of a young Russian man:}

It is surprising to see that Buddhists are offended by the existence of such bars. If you consider yourself a Buddhist and you feel your feelings are insulted because such institutions exist - please meditate over the nature of this feeling. It is already vicious if it appeared but doesn't it generate even more disturbing affects? The more people see Buddhist symbols even if under most diverse of circumstances - the more chances there are that these people will think about it (even if 1 out of 1,000), and

\footnotetext{
${ }^{3}$ A reference to Vitalii Milonov, a Russian politician famous for numerous controversial initiatives, which have included proposals to ban: hookahs, "propaganda of homosexuality," sexual education and teaching evolution in schools, as well as a proposal to form a "morality police," among many others.
} 


\section{ELECTRONIC PETITIONS OF RUSSIAN BUDDHISTS...}

will become interested, will want to listen to the Dharma and will find liberation quicker. Buddha cannot be offended and neither should we. I wish prosperity and wisdom to everybody! (Link 5 2016).

Another young Russian man writes:

Wow! Cite Buddha's words where he teaches where to use his images correctly! [two smiley emoticons] Cite any words of Buddha which you consider applicable to this case. I don't claim that you are wrong. I am just only ready to accept what corresponds to Buddha's Doctrine. IMHO such hysteria just affects negatively the image of Buddhism and can show Buddhists as aggressive fundamentalists who impose their lifestyle on other people (Link 6 2016).

Interestingly, I noticed that the commentaries critical to the petition were written by Buddhists who do not belong to traditional Buddhism of Russia. My identification of users as traditional or non-traditional was made according to their location and national identity, which was recognized by name, surname and photos of the user. Of course, the modern currents of Buddhism could influence traditional Buddhists as well, and it is impossible to judge by online presence alone whether a person practices only traditional Buddhism, but nevertheless I kept to the most general position that if a user is not either a resident of Buryatia, Kalmykia or Tuva or an ethnic a Buryat, Kalmyk or Tuvinian, then most probably, he or she is a non-traditional Buddhist, and vice versa.

The main argument of users who did not want to support the petition consisted in voicing their negative attitude towards the very idea of having one's religious feelings insulted. According to them, it is a sentiment a practicing Buddhist should work on, but not be guided by. The majority of neophytes 


\section{Bato Dondukov}

lack immersion into the Buddhist traditional environment, and consequently do not have similar feelings of the sacred and do not experience any insult. As I mentioned in the beginning of the article, the identity of neophyte Buddhists is mainly formed on the basis of Buddhist literature and lectures of visiting teachers, containing theoretical ideas about the mind and Buddhist practices. For them, a true Buddhist is focused on individual spiritual practices and does not deal with earthly concerns. The fact that they demand to be shown the exact sutra where Buddha instructed not to use his image in such restaurants indicates their willingness to act only if there is a theoretical justification I am just ready only to accept what corresponds to Buddha's Doctrine. What is more, disagreement with Valeriia Sanzhieva's initiative is formulated in such a way that it questions the Buddhist identity of those who support it - if something offends a Buddhist, then is he a true Buddhist? In other words, we can see that based on their own ideas of Buddhists and Buddhism, neophytes openly criticize actions of traditional Buddhists and almost instruct them how to behave "properly" - please meditate over the nature of this feeling. Their online demeanor may be seen as a way of fighting for their image of Buddhism, which has developed in non-traditional Buddhist environment of Russia, and even as an attempt to expand this model of practice to the regions of traditional Buddhism.

Despite the variety of opinions, this petition received over 7,500 signatures, which is almost three times more than the amount of signatures against Shivalkha Rinpoche's deportation. Such popularity can be explained by a huge resonance 
among residents of Buryatia, Kalmykia and Tuva. The petition concerning Shivalkha Rinpoche's deportation mainly circulated within Buddhist communities online, while the petition to ban Buddha Bars was actively reposted not only in Buddhist groups but also in various national groups of Buryatia, Kalmykia and Tuva. According to members of these groups, in some parts of Russia "their" religion was treated with disrespect, and that frame of reference caused the problem to escalate from a Buddhist to a national one. This was reflected by a number of comments which expressed the opinion that it was impermissible to allow such disrespectful relation to religion, as this was a sign of disrespect for the Buddhist nations. Thus, the petition has shown that the online mobilization capabilities of traditional Buddhist users are higher than those of neophytes, at least when a problem is presented as a threat not only to religion but also the national position of certain ethnic groups in Russia.

Another observation that I have made while analyzing this case concerns interrelations of laymen and monks, and different attitudes among those groups toward the petition. The protest against Buddha Bars, despite growing into a national problem, was led by laymen only. Neither Hambo Lama nor any other Buddhist leader participated in the distribution of the petition, or made any official statement about the situation. Valeriia Sanzhieva said that she addressed the BTSR and tried to attract the sangha's attention to the initiative. Despite approving of the struggle against the bars, the Buddhist Traditional Sangha of Russia nevertheless preferred to stay on the sidelines. At the same time, the sangha did not forbid laymen from advocating their 


\section{Bato Dondukov}

religious interests. Some monks offered their help on an informal level. In general, the BTSR assigned this problem to laymen and denied communication with the government by means of petitions. Thus, both of the analyzed petitions showed that official Buddhist organizations, including the BTSR, refuse to take part in e-petitioning, regardless of what the problem is or whom it concerns.

I see several reasons for this strategy. First, there is no need to master new ways of communication with the government through e-petitions, when it is possible, and even better, to communicate with the authorities directly. Second, openly supporting a lost case may look as a defeat of the Buddhist clergy and reflect badly on their image, reputation and relationship 172 with the government. It is also possible that these two cases were not significant enough for the involvement of the Buddhist clergy, and a more serious case might lead to changes in the sanghas' politics. I asked Valeriia what she would have done, if the BTSR had told her to stop her action against Buddha Bars. She answered that if the Sangha had forbidden her from sponsoring the e-petition and explained the reasons, she would have stopped her activity (Valeriia Sanzhieva, Vkontakte message to author, November 23, 2017).

Although, as was mentioned, the petition received more than 7,500 signatures, this was still not enough to solicit reaction from the official authorities it was addressed to. Nevertheless, the online community "Ban Buddha Bars" in Vkontakte emphasized that owing to the media hype caused by the e-petition and appeals to Regional Prosecutor's Offices from its supporters, Buddha Bars in Krasnoyarsk, Tyumen and Rostov-on-Don were 
either closed or rebranded. In Moscow and St. Petersburg, the Prosecutor's Office did not find any violations and the Buddha Bars continued to operate.

Are, then, e-petitions a way of consolidation or estrangement? The analysis of two petitions revealed they are both, yet at different levels. Despite its failure, the petition against deportation of Shivalkha Rinpoche showed consolidation of online Buddhist groups. Even though initially this was a problem of the Buddhists of Tuva only, they got support from various, even opposing Theravada communities, who expressed solidarity, and thus demonstrated that the fate of Shivalkha Rinpoche had become a cause common to all Buddhists of Russia. The case of Buddha Bars was an example of consolidation of Buryat Buddhists with other traditional Buddhists; however, the petition faced negative comments from modern Buddhists, which led to an estrangement in the online space. In other words, the petitions showed that the Buddhist communities of Russia are so diverse that it is not enough to just be a Buddhist to count on solidarity from fellow Buddhists, it is necessary for the problem to correspond with other Buddhists' ideas and views.

The difference in the amount of signatures also supports this conclusion: one problem managed to bring together more people than the other. What is more, the amount of signatures showed that active Internet users among Buddhists are very few. Even taken together, both petitions managed to collect a little more than 10,000 signatures, which is by far not enough for an e-petition to be proceeded by the Russian government. 
This fact is associated with another important issue: the Buddhist clergy prefers to stay on the sidelines from petitions, irrespective of the problems they address. As it turns out, it is a method of action used by laymen only. Independent attempts of laymen to solve Buddhist problems are undoubtedly a new phenomenon in Russian Buddhism, a phenomenon which shows a certain separation of laymen from the clergy. Nevertheless, new Buddhist authorities from the online space (administrators of groups, etc.) do not manage to unite enough users, and it would seem that if the official Buddhist leaders and organizations continue to ignore these initiatives, e-petitions will hardly attain any real influence on the government. Still, electronic petitions can serve as a tool for attracting public and media attention, which in some cases proved to be effective even without government participation. Undeniably, the use of electronic petitions by Russian Buddhists is a phenomenon that demands further observation.

\section{WORKS CITED}

Agadzhanian, Aleksandr S. 2008. "Neobuddizm" [Neo-Buddhism]. Entsiklopediia religii, edited by A. P. Zabiiako, A. N. Krasnikova and E. S. Elbakian, 861-2. Moskva: Akademicheskii proekt.

Barker, Eileen. 1989. New Religious Movements: A Practical Introduction. London: Her Majesty's Stationery Office.

Brabham, Daren C. 2013. Crowdsourcing. Cambridge, MA, London: MIT Press.

Buddha Bar St. Petersburg. n.d. "Fotootchet s meropriiatii restorana 'Budda Bar"" [Photo report from Buddha Bar restaurant events]. Accessed June 12, 2017. http:// www.buddha-bar.ru/rus/gallery/sobytija-cns-231001/

Change.org. n.d. "About Change.org." Change.org website. Accessed June 12, 2017. https://change.org/about/

Change.org. 2015. “Otmenite reshenie Federal'noi Sluzhby Bezopasnosti Rossiiskoi Federatsii o nezhelatel'nosti prebyvaniia (prozhivaniia) Lobsanga Gele (Dostochtimogo Shivalkha Rinpoche) i ego pomoshchnika Lobsanga Tseringa na 


\section{ELECTRONIC PETITIONS OF RUSSIAN BUDDHISTS...}

territorii Rossiiskoi Federatsii" [Cancel the decision of the Federal Security Service of the Russian Federation on the undesirability of stay (residence) of Lobsang Gele (Shivalkha Rinpoche) and his assistant Lobsang Tsering on the territory of the Russian Federation]. Change.org website. Accessed June 12, 2017. https:// www.change.org/p/президенту-рф-в-в-путину-отмените-решение-федеральнойслужбы-безопасности-российской-федерации-о-нежелательности-пребыванияпроживания

Change.org. 2016. "Zapretite Budda Bary po vsei Rossii” [Ban Buddha bars throughout Russia]. Change.org website. Accessed June 12, 2017. https://www.change.org/p/ запретите-будда-бары-по-всей-россии

D’Andrea, Anthony. 2007. Global Nomads: Techno and New Age as Transnational Countercultures in Ibiza and Goa. New York: Routledge.

Dondukov, Bato. 2015. "The Global Space of Dialogue and Conflict: The Case of Russian Buddhists." Kultura - Historia - Globalizacja website. Accessed May 8, 2017. http://www.khg.uni.wroc.pl/files/4\%20KHG_18\%20Dondukov\%20t.pdf

Faure, Bernard. 2011. Unmasking Buddhism. Chichester: John Wiley \& Sons.

Federal'nyi zakon. 1996. "Federal'nyi zakon ot 15.08.1996 N 114-FZ 'O poriadke vyezda iz Rossiiskoi Federatsii i v"ezda v Rossiiskuiu Federatsiiu'” [Federal Law No. 114-FZ of August 15, 1996 "On the procedure for leaving the Russian Federation and entry into the Russian Federation"]. Konsul'tantPlius website. Accessed July 10, 2017. http://www.consultant.ru/document/cons_doc_LAW_11 376/9a9ca39cd15427dc0ea954b4c41eb5bb6928551e/

Filatov, Sergey and Roman Lunkin. 2005. "Statistika rossiiskoi religioznosti: magiia tsifr i neodnoznachnaia real'nost" [Statistics of Russian religiosity: The magic of numbers and ambiguous reality]. Rossiia i musul'manskii mir 6 (10): 35-45.

Garri, Irina R. 2014. "Tibeto-buriatskie vzaimootnosheniia: Istoriia i sovremennost"” [Tibet-Buryat relations: History and modernity]. Vestnik BNTS SO RAN 14 (2): 160-6. Higgins, Winton. 2012. "The Coming of Secular Buddhism: A Synoptic View." Journal of Global Buddhism 13: 109-26. Accessed November 8, 2017. http://www. globalbuddhism.org/jgb/index.php/jgb/article/view/128

Howe, Jeff. 2006. "The Rise of Crowdsourcing." Wired Magazine website. Accessed August 15, 2019. https://www.wired.com/2006/06/crowds/

Macintosh, Ann. 2004. "Characterizing E-Participation in Policy-Making." In Proceedings of the 37th Annual Hawaii International Conference on System Sciences. CiteSeerX website. Accessed October 12, 2017. http://citeseerx.ist.psu. edu/viewdoc/download?doi=10.1.1.98.6150\&rep=rep1\&type=pdf

McMahan, David L. 2008. The Making of Buddhist Modernism. Oxford: Oxford University Press.

Mongush, Marina V., and Evgenii D. Mongush. 2015. “Kul'tovye mesta v kul'turnykh landshaftakh Buriatii i Tuvy" [Cult places in the cultural landscapes of Buryatia and Tuva]. Novye issledovaniia Tuvy website. Accessed June 26, 2017. https:// www.tuva.asia/journal/issue_26/7899-mongush-mongush.html

Nesterkin, Sergei P. 2008. "Nekotorye tendentsii razvitiia buddizma v Rossii" [Some trends in the development of Buddhism in Russia]. In Buddiiskaia kul'tura: Istoriia, 


\section{Bato Dondukov}

istochnikovedenie, iazykoznanie i iskusstvo: Sbornik mezhdunarodnoi konferentsii “Tret'i Dorzhievskie chteniia," edited by A. O. Boronoev, 43-51. Sankt-Peterburg: Nestor-Istoriia.

Russia Religion News. 2015. "Buddhists Challenge Lama's Expulsion in Court." Accessed July 10, 2017. http://www2.stetson.edu/ psteeves/relnews/151012a.html Schonhardt, Sara. 2013. "Food Fridays: A Tasteful Journey Through Jakarta History." WSJ Magazine website. Accessed July 10, 2017. https:/www.wsj.com/articles/ BL-SEAB-3131

Tsyrempilov, Nikolai V. 2013. Buddizm i Imperiia: Buriatskaia buddiiskaia obshchina $v$ Rossii (XVIII-nach. XX v.) [Buddhism and Empire: Buryat Buddhist community in Russia (18th to early 20th centuries)]. Ulan-Ude: IMBT SO RAN.

Ukaz. 2013. "Ukaz Prezidenta RF ot 4 marta 2013 g. N. 183 'O rassmotrenii obshchestvennykh initsiativ, napravlennykh grazhdanami Rossiiskoi Federatsii s ispol'zovaniem internet-resursa "Rossiiskaia Obshchestvennaia Initsiativa."," [Decree of the President of the Russian Federation of March 4, 2013, no. 183 "On the consideration of public initiatives communicated by citizens of the Russian Federation using the Internet resource 'Russian Public Initiative'"]. Garant.ru website. Accessed June 12, 2017. http://www.garant.ru/hotlaw/federal/460360/

Zhironkina, Yuliia. 2015. “Glava Tuvy provel vstrechu kasatel'no dal'neishego prebyvaniia v respublike Izvestnogo buddiiskogo uchitelia Shivalkha Rinpoche" [The head of Tuva held a meeting regarding further stay in the republic of the famous Buddhist teacher Shivalkha Rinpoche]. Fund "Save Tibet" website. Accessed July 10, 2017. http://savetibet.ru/2015/10/02/shivalha-rinpoche.html

\section{ANALYZED MATERIAL}

Link 1. Posted September 26, 2015. https://vk.com/public53269?w=wall-53269_7216 Link 2. Posted October21, 2015. https://vk.com/theravada_ru?w=wall-12841451_9180 Link 3. Posted October 2, 2015. https://vk.com/topper_pannyaavudho?w=wall58420 $061 \_337 \%$ 2Fall

Link 4. Posted July 29, 2016. https://vk.com/club26370?w=wall-26370_66377_r66473

Link 5. Posted July 29, 2016. https://vk.com/ban_buddha_bars?w=wall-125503969_733 Link 6. Posted July 29, 2016. https://vk.com/ban_buddha_bars?w=wall-125503969_63 


\section{LANDSCAPE AND INDIGENIZATION}




\title{
Zbigniew Szmyt
}

ORCID 0000-0001-6658-0317

Adam Mickiewicz University, Poznań

INDIGENIZATION

OF URBAN LANDSCAPE IN ULAN-UDE

\begin{abstract}
The main emphasis of this paper is on Buryat place-making in Ulan-Ude. In order to provide insight into the variety of social behaviors in this regard, attention has been pinpointed upon indigenization of urban landscape and architecture, shamanic activity in the city, new temporalization and local politics of memory. As a consequence of these processes, new indigenous senses of urban space, time and history are established.
\end{abstract}

Keywords: place-making, indigenization, Ulan-Ude, Buryatia, Siberian city, urban anthropology

\section{REASSEMBLING OF URBAN SPACE}

In the beginning, the future Ulan-Ude was a Cossack fortress on the upper Uda River, built in 1666 in order to suppress and control the indigenous population. In 1783, Verkhneudinsk gained the status of district town and throughout the 19th century was an important trade hub on the way from China and Mongolia to western Russia. In 1920, it became the capital 


\section{Zbigniew Szmyt}

of the Far Eastern Republic (temporary buffer state) and in 1923 - the capital of the Buryat-Mongol ASSR (Breslavskii 2012, 299). Memoirs and colonial documentation show that in the suburbs of 19th century Verkhneudinsk there were Buryat settlements, but their inhabitants did not have the status of city denizens (Zhimbiev 2000, 32-4). They had no right to the city, or rights in the city.

The situation changed nominally in the 1920 s, when Verkhneudinsk became the capital of Buryat-Mongol Autonomous Soviet Socialist Republic. At that time, some native party officials and members of the brand new native proletariat began settling in the town. This change was empha180 sized in 1934, when the town was renamed Ulan-Ude - Red Uda. This may be marked as the concluding stage of the city's rite of passage: from provincial colonial town to the capital of Buryat-Mongol Autonomous Soviet Socialist Republic. The status of the republic's capital brought with it a transformation of the urban landscape, of relations of production and of the city's symbolism. A brand new city center was constructed around the newly delineated Soviet Square, with a monstrous bronze Head of Lenin monument surrounded by government buildings. Next to the square other public buildings arose: Radio House, the Buryat Pedagogical Institute and the Buryat Opera and Ballet Theater - an eclectic fusion of Stalinist Empire style with orientalism. To this day, the square is a part of the heritage which the city has obtained through its position at the heart of Buryat national life and government (Humphrey 2002, 178; Zhimbiev 2000, 79). Simultaneously, as time went 
on, the former commercial town began to transform into an industrial city.

Ulan-Ude became a space in which a new communist Buryat elite was formed. This was just one element of a wider Bolshevik program of empowerment and emancipation of national and ethnic minorities in the Soviet Union. Buryats made use of the new channels of social mobility provided by Soviet modernization and of privileges under the socialist autonomous republic system. By the 1970s, a new urban ethnic elite formed (Chakars 2014, 89-116; Batomunkuev 2003). We may say that they mostly chose to assimilate motivated by the idea of progress and, at least in the public sphere, they were acting as New Soviet Men. However, mass migration of native population to the city began only in the early 1980 s and became a significant demographic phenomenon in the 1990s as a result of the state farm system crisis (Mitupov 2002, 105-9).

Until that time, Ulan-Ude was a generic Russian-speaking and Soviet-looking city. The ethnic character of this region was attested to by the regional museum and the Buryat Theater of Drama. Soviet emancipation of ethnic minorities was designed in the center (Moscow) and implemented in the peripheries without wide-ranging consultation with local communities. Furthermore, the Soviet idea of native Siberians emancipation was closely connected with modernization and manifested itself in the new factory, hospital and school, but not necessarily in accounting for cultural peculiarities in urban plans. And so, Russians kept a demographic and cultural hegemony in the city for the whole USSR period. As I talked with urban Buryats, 


\section{Zbigniew Szmyt}

gradually I gained one definite impression that in Soviet times their everyday practices were based on a clearly evident spatial dichotomy between the city and the collective farm (kolkhoz). The city was the place of exercising the modern form. In rural areas, state farm modernization took place in the domestic, tamed space, which allowed for incorporating a number of elements of ethnic culture. For this reason, some shamanic practices could take place in rural areas, next to collective farms, but had no right to exist in the urban public space. That meant that the same person could behave differently in two different social spaces. Sometimes this can be seen even now, especially on the language level. Old Buryat urbanites often start to speak Buryat instead of Russian when they come to their villages of origin, but if someone publicly speaks Buryat in the city, they take it as a rude or even aggressive act.

This radical dichotomy has changed in the last three decades as a consequence of mass Buryat migration from rural areas. In 2002, more than $33 \%$ of Ulan-Ude's inhabitants were Buryat. ${ }^{1}$ Decommunization of the city was never carried out completely, maybe because the titular nations had no urban past of their own to restore and it made no sense to restore Russian dominance from imperial times. That is why a new temporalization was needed.

When I visited Ulan-Ude for the first time in 2000, it had all the appearances of an ordinary post-socialist city, which are very

\footnotetext{
${ }^{1}$ The number of Evenki people is still small. This is because of their long-standing tendency to assimilate with Buryats or Russians. However, the Evenki play an important symbolic role in the city as an indigenous nation.
} 
common also in Poland. The visibly ethnic architecture was limited to the few cultural institutions: the museum, the theater and an ethnographic park located in the suburbs. As a tourist, thirsty for exoticism, I was deeply disappointed by the city's unremarkable Soviet greyness. It is possible that behind that kind of communist universality lay the foundation stone of an indigenous empowerment policy. For the Bolsheviks, true emancipation could only be brought about by accelerated modernization and rapid development of the communist socio-economic formation. The indigenous peoples' rights were, therefore, the rights to the communist future, with free education, public health and industrialization. In other words, Siberian native populations, as much as the next Soviet people, gained the right (and duty) to achieve the communist utopia (Kotkin 1995, 15).

As I mentioned, the change of the city's status did not lead to immediate demographic changes. It was not until the 1980s that Buryats became a numerous group among the city dwellers. For a long period, the dominant group in Verkhneudinsk/Ulan-Ude were Russians. The complex transformation of urban space and its inhabitants gained speed with the disintegration of the Soviet Union, which provided the starting point for the migration of Buryats from impoverished rural areas to the city. Embarking on its post-Soviet path of building a market economy, Buryatia had to deal with the fallout of the disintegration process, including the collapse of the industry. At the same time, the urban identity began to undergo some surprising transformations. After the collapse of the Soviet state, we may observe a new reassembly of urban space (Chakars and Sweet 2018, 168-70). 
While in Soviet times, the vector of urban identity was directed toward the future, nowadays it is directed toward the past. A new vision of society is focused not on universal progress, the future-to-be-created, but on an abandoned and undead ethnic past, a process that Zygmunt Bauman calls "retrotopia" (Bauman 2017). The urban space started to obtain new symbols related to pre-revolutionary Buryat past: monastic Buddhism, nomadic heritage and the glory of the Genghis Khan Empire. These symbols and practices refer to ethnic history, but at the same time are completely new in the urban landscape. The process depicted here could be designated "indigenization of urban space."

The main emphasis of this paper will be on Buryat placemaking in Ulan-Ude. In order to provide insight into the variety of social behaviors in this regard, an increased focus will be put on: (1) indigenization of urban landscape and architecture; (2) shamanic activity in the city; (3) new temporalization and (4) local politics of memory. Drawing on my three-month ethnographic fieldwork in the city of Ulan-Ude in 2015, I will show how in consequence of these processes, new senses of urban space, time and history are established, and a former colonial town and Soviet industrial city is being transformed into the ancient native capital - the oldest town in the Russian Federation - built by Huns 2,300 years ago.

\section{INDIGENOUS PLACE-MAKING}

The term "indigenization" has been used to describe a process of introduction of native symbols, architecture, monuments 
and other sites of memory into the urban space. In the course of indigenization, the city does not transform itself into an ethnographic park or a historical reconstruction of a pre-colonial town, e.g. Karakorum - the medieval Mongolian capital. Rather, the desired result is achieved by the ethnic stylization of landscape and introduction of brand new elements, such as Buddhist and shamanic temples (Hürelbaatar 2007; Quijada, Graber and Stephen 2015, 261-2). Yet modes of perceiving and processing landscape are a significant element of ethnic boundary-making (Smyrski 2016, 25-8) and the process of indigenization may thus legitimize demographic changes occurring due to an influx of native population (Buryats and Evenks) into the city. In this particular case, indigenization contributes to symbolic marginalization of local Russians, while the hegemony of Russian language and culture remains unchallenged. In the exercise of indigenization, urbanites split into the host minority (Buryats and to a certain extent Evenks) and interlopers (the Russian majority and others nationalities). As odd as it may seem, this process simultaneously consolidates state power. In my opinion, this is a result of an informal social contract: the Buryat political elites are completely loyal to the state, and in return the central government agrees to their domination in the republic.

Since the beginning, indigenization has been accompanied by de-modernisation, de-industrialization and economic crisis. For many years, the local government has been fostering the belief that the development of the tourist industry can and should become an effective remedy against the resulting economic damage (Breslavskii 2012, 119). This has led to ethnic and 


\section{Zbigniew Szmyt}

cultural diversity becoming a commodity, embodied by its tradable performances and artefacts. People started to perform cultural identity, and the uniqueness of their ethnic heritage became a product for tourists (Wood 1984; Comaroff and Comaroff 2009, 24). The tourism potential of the Buryat capital is a sound argument in favor of Buryat self-folklorization and an indigenous turn in the urban landscape. These can be seen as a form of indigenous people's adaptation into the global market (Szynkiewicz 2007; Nathan, Kelkar and Walter 2004). The current ethnic identity is therefore closely related to the tourism industry, in the frame of which ethnic culture becomes a product, but it should be remembered that the costume and stage forms of representing ethnicity were developed and imposed in Soviet times (Sántha and Safonova 2011). ${ }^{2}$

In turn, indigenous place-making can be viewed as a process that is transforming the identity of urban space from colonial to native, but is not necessarily calculated to catch the tourist's eye. It is also a way of reframing both the past and symbolic land possession; a collective strategy in the fight for public space. In other words, alien urban space is being socialized by city dwellers and transformed into an indigenous place with new indigenous meanings. In this context, places should be considered as spatially located social relations, and the products of these relations - as an important element of grassroots political movements (Agnew 2011). Thanks to new temporalization, ethnic architecture,

\footnotetext{
${ }^{2}$ There are good grounds to hypothesize that the root of the problem is to be found in the statization of ethnicity in the Soviet period (Slezkine 2000); however, I am unable to elaborate on this issue due to the space limitations of this paper.
} 
and ritual and daily practices, Buryats obtain their right to the city, which David Harvey defined as the collective "right to change ourselves by changing the city" (Harvey 2008, 23).

\section{TRANSFORMATION OF LANDSCAPE AND ARCHITECTURE}

Compared to their share in the total population, Buryats are strongly overrepresented in both the City Council and local government. Those two centers of power are engaged in shaping the city's ethnic outlook. A very popular form of indigenization consists in introducing into the urban landscape ethnic-oriented elements of architecture: yurts, "nomadic" monuments, buildings which refer to a style of architecture that has taken shape in Tibet and China and was adopted by Buryats thanks to Buddhism.

In 1999, Ulan-Ude's first big ethnic monument was erected under the auspices of Mayor Gennadii Aidaev. It was a sculpture of a Buryat archer - Mergen, commonly referred to as "Mer-Genna" (MAyoR-GENNAdii). The archer drops to one knee on Karl Marx Boulevard. Another, 26-foot-tall statue in bronze, known as "Mother Buryatia," is located on a hill in front of the Opera Theater, next to the central Soviet Square. She is depicted as a beautiful young woman in traditional dress holding two main attributes of hospitality, a ritual scarf (khadag) and an aiag bowl. One more sculpture is located in the city's Old Town, between the tank commemorating the fallen Soviet heroes and the stone cross on Batareinaia Barrow, erected to 


\section{Zbigniew Szmyt}

symbolize the arrival of the Cossack "pioneers" who founded the town. It depicts Geser Khan - a hero of the main Buryat epos and a protective deity for both Buddhists and shamanists.

Moreover, bronze statues of Mongolian warriors, and animals characteristic of Mongolian folklore have been put up on the municipal bridges. All around the city we may also find figures of horses and riders, which refer to the nomadic heritage of the city dwellers. Idyllic monuments of pre-colonial and mythical heroes are set against Soviet-time memorials, which mostly celebrate people who fought for the modern future: workers, engineers, communist leaders and Soviet soldiers. Those two kinds of monuments show a paradox of two utopias: the communist future (which belongs to the Past) and the nomadic past, which belongs to the Future to the extent that it is a part of the "ethnic revival" project. Yet also the main communist monument - the grand Lenin's Head - will beyond a shadow of a doubt be preserved for future generations. The cephalized Soviet Square is recognized as the city's essential trademark. Monumental works of art commemorating Lenin and the Great Patriotic War show the city authorities' true allegiance to the communist roots of the republic.

Of course, we may also observe attempts to invoke the tsarist past in the urban landscape, like in the case of the reconstructed King's Gate Triumphal Arch or the Old Town market square with the merchants' row and Orthodox churches. With that architecture, the city advertizes itself as a municipality with a vigorous merchant tradition and a history of complex interethnic connections, resulting from its location on the Tea 
Road trade artery. Thus, some efforts have been made to ensure that reconstructions of the Russian Empire period do not show an exclusively Russian face. The reconstructions awake and develop a new sense of Russian historical presence in Buryatia as a part of the larger Eurasian trade network.

The City Council's efforts to introduce so-called traditional Buryat culture into the urban space have been relatively easy when it comes to memorials, but what about buildings? If we apply historical criteria to house-building, it would seem that the Buryat urban style has not as of yet developed. However, it is possible to indicate two types of structures that one may associate with Buryat-Mongolian culture: the yurt (ger) and the Buddhist temple, monastery and shrine (datsan, khüree, dugan). Before the 1930s, Buddhist monasteries and temples were located in remote settings and represented mostly Tibetan or Chinese-style architecture. Nevertheless, Buddhist temples eventually emerged as a local tradition and continue to set the standard for Buryat-style urban architecture. Some elements of monastic architecture are oft-quoted in modern buildings, and Buddhist temples themselves stay in step with the times and successfully penetrate the socialist urban fabric. In the first case, we are faced with a symbolic indigenization of modern urban space, while in the second case traditional architecture is placed in non-traditional space. Buddhist temples not only emphasize the Asian character of the city but also become centers of Buryat language and culture.

It is worth to remark that Buddhist temples were incorporated into some Soviet urban rituals. The wedding rituals are 
a brilliant example of a syncretism providing new forms of indigenous urban "tradition." I believe this phenomenon is worth elucidating in more detail. In Soviet times, new secular wedding observances were created based on Russian rural customs. To date, the vast majority of marriages are still concluded in the Civil Registry Office. After the civil ceremony, the newlyweds and wedding guest take part in riding around the city - katanie po gorodu. The first stop after the office is a visit to a Soviet "site of memory," where a photographer takes collective wedding pictures and the young couple drinks champagne. My own observations show that this takes place according to a strictly formalized ritual. In many Siberian cities (e.g. in Irkutsk), the 190 site is a monument to Soviet soldiers who fell in battles during the Great Patriotic War, in front of which burns the "eternal flame." In Ulan-Ude, the function of Soviet sacred spot is played by Lenin's Head. The head is revered equally by Russians and Buryats. Buryat newlyweds, however, go well beyond the Soviet sacrum. The next step is to visit a Buddhist temple, where the young couple perform prostration in front of the statue of Buddha, asking the monks for a blessing. Pictures are again taken at various parts of the temple. By this token Buddhism, instead of entering into competition with Soviet rites, has been introduced into the system. Thus, marriage is being sanctioned by three orders: the state (in the office), the Soviet past (at the foot of Lenin's Head) and Buddha (in the temple).

While the rituals performed in the first two places affirm the moral social order common to Russians and Buryats, rituals in the Buddhist temple help to establish and sustain Buryats as an 
ethno-confessional group. It is important to note that it is a public and ritual social reproduction acted out on the stage that is the city. One of the effects of the new wedding tradition is, therefore, the appropriation and domestication of urban space by the community. What sets this invented wedding tradition apart from older customs is that it has been fixed, instituted and ritualized so as to call upon historical legitimization (Hobsbawm 1983, 2-8) to answer problems peculiar to the post-Soviet urban society.

The next stopover is at the open-air Ethnographic Museum, where wedding guests have time to bend their elbows, while the photographer is trying to capture the perfect shot of the young couple with yurts and camels as the backdrop. A few hours later they finally reach a restaurant and the main part of the wedding party gets started. Participants consist mainly of the two kinship groups, but also friends of the young couple and respected representatives of the region from which the families originate. This part of the wedding reproduces the kin-territorial bounds and hierarchy. It features numerous Buryat customs, although these are mixed with elements typical of Russian weddings as well as artistic displays and competitions organized by the wedding attendant.

Buryat weddings can hold a few hundred revellers, and therefore require ample space. This creates a need for halls corresponding to the Buryat vision of the urban wedding. In the suburbs, near the Ethnographic Museum and a Buddhist monastery, such function is performed by a huge, two-storey banquet yurt for 600 people. This Grand Yurt, which is advertised as the largest one in the world, is another example of the invention of 


\section{Zbigniew Szmyt}

indigenous urban architecture. The nomadic tent that became obsolete in the early decades of the 20th century has been enlivened these days within a brand new socio-spatial milieu and has acquired new functions and new characteristics. It is common practice to run a small snack bar serving Buryat cuisine or a souvenir shop in a yurt. Yurts from Mongolia have been set up in various parts of the city. Urban yurts, unlike in Ulaanbaatar, are not residential structures - they are part of indigenous stylization.

It is fair to assume that the indigenization of urban landscape has just started to pick up steam. In the center of the Soviet District stands the new headquarters of the Arun State AllRepublic Evenki Cultural Center. ${ }^{3}$ This high-rise structure, 192 made of concrete and glass (the building's total floor area is about 7,000 square meters) has the form of a conical tent a traditional dwelling of Evenki reindeer breeders. That style of ethnic architecture was probably inspired by modern Mongolian "national" style and the Chinese "architecture of ethnic minorities" (Yang and Wall 2014, 118-203). ${ }^{4}$ A distinctive feature of most of such vernacular architecture is a selective transfer of ethnic forms from the practical to the symbolic dimension.

Yet, as was mentioned, monuments and architecture do not exhaust the indigenizing efforts in Ulan-Ude. In what follows, attention will be paid to more performative aspects of the city's indigenization.

\footnotetext{
${ }^{3}$ Arun means "awakening" in the Evenki language.

${ }^{4}$ In Ulan-Ude, the prototype of this kind of eclectic architecture was the Mongolian Consulate, built in 1991. It consists of a slightly trapezoidal block, owing to which the building evokes the Tibeto-Mongolian monastic style, and of the central dome, which refers to the yurt. The blue color of the building symbolizes the eternal blue sky - the supreme deity of medieval Mongols.
} 


\section{SHAMANS AND NEW TEMPORALIZATION}

New temporalization of urban space is one of the most important dimensions of the Ulan-Ude ethnic renaissance. It should be considered as a complex practice dealing with colonial and Soviet past, whereby the indigenous, Buryat and Evenki, citizens exercise their right to the city by performative practices of indigenization of public space. Some of these practices are part of a strategy created by ethnic activists and indigenous representatives in the City Council. The City Hall, too, got involved in efforts to shift periodization of the city's foundation: from that of Udinskoe (colonial fort settled by Russian Cossacks) in 1666 to that of Huns City (Bur. Khünnü khoto - ancient settlement founded by postulated ancestors of the present Buryats) in the 3rd century BC.

Apart from those practices, we can identify many unarranged ones: dreams about the past, topos-shaping urban legends, creation of shamanic sacred sites and sites of memory, shamanic rituals which give animation and new temporality to urban space, and mass illegal squatting - uncontrolled building of log houses (relocated from villages) on any available piece of vacant land (Zhimbiev 2000). A thorough analysis of all these practices is outside of this paper's scope. For our purposes, it will be enough to concentrate on a few shamanic and memory practices that are introducing indigenous temporality into the city: dreams, urban legends and sacred sites.

Dreams are a very important element of new temporalization. In a dream, one may communicate with the ancestors, see 
the future or understand the past. Dreams of the people with shamanic roots (utkha) are recognized as especially meaningful and prophetic. We can say that shamans, but also lay people, are using dreams to interpret and transform their personal and social condition. It gives them the opportunity to wrest control of the colonial past, and to frame themselves in a host position in the urban milieu. One of my fellow anthropologists, who also practices as a dentist, gave me a brochure in which he presents his philosophy and his dreams:

It is astonishing but before my first shamanic initiation I saw in several dreams my former incarnations. ... In the second dream, I saw myself as an Orthodox priest, and that is why people called me "Father Mikhail" and it was in merchant Trunev's house - where Arbat [Street] and Dental Clinic No. 1 now are. I could see clearly that the hosts, Trunev and his wife, were arguing, and I stood at a pause in front of a slightly open door. The servants were coming and greeting me, I was making a sign of the cross over them and they were kissing my hand in response. Then I went to work - to the church that was located in the municipal garden in Batareika [District]. I experienced old Verkhneudinsk for real, around the church there was the only fenced cemetery, from where, slowly but with solid step, a clear-cut crowd of ghosts of the dead were coming in my direction. Currently, I work as a doctor in a dental clinic - in the former house of merchant Trunev. So it would seem that karmic connections with this house brought me here but in another form (Khobrakov 2009, 21-2).

By way of dreams about a former incarnation, the author attempts to connect himself with the city's history. He has been on the urban stage for centuries, just changing costumes; he was a Russian priest and now he is a Buryat dentist. Today, a hundred years later, he works in the place which he remembers from the former life. Such stories were common enough to call them social facts. They could be interpreted as attempts to break 
a Russian monopoly over the city's past. Oneiric narratives in which current members of the Buryat elite are present in the Tsarist city in Russian bodies are one of the strategies that empower newcomers. Other practices concentrate on alternative historical narratives.

One such practice has to do with the urban legends and folktales that often accompany, and operate with, shamanic rituals. Oral genres have a great tradition and are very popular among (post)nomadic groups. We can find plenty of oral stories that have spurred people to action or changed their social status. Nowadays, such narratives are also widespread in Internet blogospheres and chats. Although no longer oral-only stories, they keep their folk, anonymous character; the same stories one can hear in the minibus public transport, one can read on the Internet. In some cases, urban legends help to decolonize the past and space by creating new toposes or sites of memory (Nora 1989). Such "embodiment[s] of memory in certain sites where a sense of historical continuity persists" (Nora 1989, 7) have been established in city landscape because the urban Buryats no longer belong in pastures or the nomadic environment. Spatially located public commemoration of the past reproduces their ethnic identity in Ulan-Ude and undermines Russian hegemony at the same time.

A topos that became the nodal point around which ethnic conflict and urban legends constantly revolve is Batareinaia Gora - the hill where the first colonial settlement was established in 1666. In 1991, Russian activists put a memorial stone cross there and since that time they have tried to set up a monument 


\section{Zbigniew Szmyt}

to the memory of Cossack pioneers. Buryat activists work to countervail that project. Not far from the Cossack cross, on the place where the Cossacks are believed to have kept Buryat hostages (amanats), they put a wooden tethering-post for the spirits (serge), and started to conduct shamanic rituals there (Nowicka and Wyszyński 1996, 135-6).

Shamanic symbolic actions became in this case rituals of rebellion, but not necessary as defined by Max Gluckman (1954). Shamans engage ritualized forms of resentment in order to express their disagreement with colonial discourse. However, through this ritual expression of hostility to official narratives, their subaltern status is ultimately overcome and a new tempo196 rality is established. Considering the performative character of shamanic acts, a probably more accurate term would be "rituals of subversion." By way of ritual performance, shamans subvert Russian domination in the city and Russian right to its history. Unlike in Soviet times, the state is no longer the monopolistic guardian of the past. Public memory becomes a battlefield for the two main ethnic groups, which have an unequal and ambiguous status: the Russians are the urban majority, whereas the Buryats are the titular nation in the republic but newcomers in the city. It is a striking paradox that even though Russians generally do not take part in the rituals, it is their social status that is being transformed there. Step by step, they become alienated in the city that their predecessors built and, of course, are not happy about the symbolic violence perpetrated against them. The shamans have devised an effective counter-narrative to Russian colonial historiography and the indigenous urbanites 
have added it to their arsenal. Local Buryats have started to claim that the Batareinaia Barrow was an ancient shamanic sacred place:

Before Russians built the fortress, there was a Buryat worship place. On that site, our shamans had been offering worship to powerful [spirit] lords of this land. The Russians intentionally built their stronghold on this place, as they built churches on our holy places. In effect, the Buryat community started to take a dim view of Russian activists' efforts to establish a monument to Cossack pioneers, and a strong grassroots lobby against building the monument appeared. Perhaps for Russians, the memorial was crucial to establishing and maintaining their identity. Through this monument and celebration of the city location anniversaries, they try to organize and delimit the individual memories of citizens. But for Buryats, it was an unacceptable attempt to humiliate their dignity and take possession of the history of their capital. It is a commonplace practice to assemble public memory in the public space, using historic monuments to stake a claim to the city (Bulutov 2012).

Russian activists seem to fight here against at least two types of forgetting: prescriptive forgetting and forgetting that is constitutive in the formation of a new identity (Connerton 2008, 61-4). The City Council and local government prefer to talk about "peaceful incorporation" of Buryat tribes into the Russian Empire. For fear of interethnic hatred, commemorations of Russian colonial domination are unendorsed by local officials. On a more subtle level, forgetting Russian domination is a part of silent decolonisation of urban space that enables the Buryat newcomers to obtain the identity of the city's hosts.

Resistance against the monument has caused many people to see the Russo-centric character of Ulan-Ude's history. Some journalists, scientists and bloggers have started to deal with the native status of "people without history" by creating an alternative 
history of Ulan-Ude. During this process, no scientific procedures have been performed, so primary historical sources have been enriched with folktales and legends, and have become full of fads and fancies. Yet it has the performative power to conquer back the city's past and sacrilize (ethnicize) some public sites.

The Uda estuary and Selenga banks were a pretty busy place, there was a place called "Chuckie-Stone" and on the top of that rock was an Oboo. ... Shamanic rituals attracted to the "Chuckie-Stone" large numbers of Buryat nomads. ... Another important factor is that the Uda estuary was a part of the nomad grounds, the ulus [state] of Buryat-Mongol prince Turukhai Tabun - a well-known historical figure. Here we can clearly see that at the Uda estuary - called by Buryat-Mongols "Udyn Adyg" until the alien Cossacks [came] - there stood two sacred Oboos. That means that this is a sacred place of the Buryat-Mongols. And according to the Federal Law No. 136-F3 of June 30, 2013, in order to counter the actions offending religious beliefs and feelings of citizens, two sacred Oboos should be restored to the sacred place in the Uda estuary. Only these two sacred Oboos have the right to stand at that place and nothing else. No need to commit sacrilege yet again! (Vasil'ev 2015).

The former Cossack fort has been a starting point for the process of new indigenous temporalization. Various practices, including shamanic rituals and selection of historical evidence and folk tales, are consequently used to reframe the native public memory, and also other urban sites have become scenes of shamanic rituals of subversion. One of the most popular locations for shamanic rituals is a suburb called Verkhniaia Berezovka in Russian, whose Buryat name is Deede Ongostoi ("the upper place filled with ancestral spirits"5). This space was incorporated within the limits of the city in 1930, causing several Buryat

\footnotetext{
${ }^{5}$ In fact, the word ongostoi means "pine forest" (Badmaeva 2005, 76), but probably as a result of shamans' activity people started to associate this word with ongontoi - "a spirit."
} 
households to be displaced to another rural region. Yet although the master plan for this area was created in 1930, there was little subsequent development and the land kept its peripheral character until the 1990s. The only spectacular investment was the huge open-air Ethnographic Museum. Nowadays, the district is mostly a leisure center and a cottage area. After the USSR collapsed, the Buddhists built a monastery there and the Orthodox put up a modest church. Local Buryats claim that Deede Ongostoi is a very powerful place and it were the local spirits that did not allow the Soviet authorities to build any industrial architecture there. The spirits only gave the nod to the museum in a bid to additionally empower this land with a large number of shamanist exhibits (Hürelbaatar 2007, 145-7). In the opinion of native amateurs of the local history, Deede Ongostoi became a shamanistic sacred place after the Cossacks settled down on Batareinaia Barrow and cut off the road to the previous sacred spot (Bulutov 2012).

Urban shamans also perform rituals within the territory of the archaeological site called the Huns City (Bur. Khünnü khoto), located on the outskirts of Ulan-Ude, near to the village of Ivolginsk (Bur. Ivalga). It is a widespread idea that the builders of the settlement, the Xiongnu - otherwise known as the Hunnu and often identified with the European Huns - are closely related ancestors of present-day Buryats. Shamans performing sacrifices on this site venerate the Huns/Xiongnu as progenitors of Buryat clans. By connecting Buryats with the ancient Huns, the shamans undermine classical urban temporality. The Huns play the role of the first urbanites and builders of the city 


\section{Zbigniew Szmyt}

2,300 years ago, a long time before Russians appeared. The Russian colonization and Soviet periods are transformed into relatively insignificant episodes in the history of the eternal city of the Huns. The idea of Ulan-Ude as the oldest city in Russia is propagated by the so-called Hunnic Fond (an NGO), but the City Council also supports it, probably because it is counting on the growth of tourism. The archaeological site becomes a center of indigenization of the urban past. In 2011, the Buryat State Academic Opera and Ballet Theater staged Attila by Giuseppe Verdi over there, after which a Hunnic fashion week was held. A reconstruction of a Hunnic hillfort on an Uda River island is the first planned Hunnic investment. Moreover, the Hunnic Fond and local archaeologists strive for UNESCO World Heritage status for the Hunnic archaeological site. The new periodization of urban history was presented in a film by the president of the Hunnic Found, Oleg Bulutov:

We are not descendants from the Huns - we are Huns and we have to understand this about ourselves. And the history of Huns' City is our history. ... 2,300 years ago, the city was already here and the first burgers appeared in that period; there was a school there, crafts workshops, houses. ... The whole territory around had been inhabited. [On the place where in the 17th century Cossacks built a ring fort] we had had a trading factory for Middle Asian merchants. ... It was a mediaeval factory, from the 9th century to the 15 th century. ... Cossacks were the latest wave of immigration to the well-dwelled area, and they considered themselves as descendants from the Huns, too, since they used to belong to the Golden Horde (Fil'm o gunnakh n.d.).

Turning urban sites into ancient and sacred shamanic places is a modern practice of new temporalization that undermines Russian hegemony in the urban past and present. Shamanic sites 
link urban Buryats with the pre-colonial period. For that reason, shamans perform rituals in Huns City, where evidence of Hun (Buryat) past activity is preserved. Michael Guggenheim argues that "modernity is a process that tends to turn anything into an object with a history and a biography" (Guggenheim 2009, 39). Thus, temporalization is accompanied by a boom in memory sites protection and restoration. It also provokes conflicts about the destiny of monuments, buildings and archaeological sites. It is from that perspective that we should view the processes of the new temporalization of Ulan-Ude/Huns City. Hunnic origins of the city become the leitmotif of the indigenous counter-narrative to colonial historiography. Of course, any attempt on the part of indigenous people to write their own history entails submission to axiomatic structures of the Western episteme (Basu Thakur $2016,11)$. Nevertheless, we can say the same about any use of the modern form. The important thing is that shamans and other native actors transform the archaeological site (constructed by Western science) to fit their historical representation in the urban space. The civic project of Huns' City reconstruction, actively promoted by Oleg Bulutov, has been included in the urban development plan. The Hunnic settlement is under construction on an Uda River island.

Shamanic practices open up alternative possibilities to look into the past. While historians could only pose questions about sources (in my opinion, "dialogue with the source material" is just a pompous metaphor), shamans can talk with the spirits of individuals from the past. They can pick interlocutors and very often they choose ancestral spirits of the shaman's clients 


\section{Zbigniew Szmyt}

or famous persons. During these conversations, new historical narratives appear as sources with unique ontological status and insight into the past. Buryat shamans are able to communicate with persons from recent history (e.g., tormented spirit of a victim of the purges during socialism) or medieval ancestors (e.g., a soldier of Genghis Khan's army, or tribal leaders who organized resistance against Russian colonization). In fact, the shaman has to interview the spirit to discover his or her personal history. It is a conditio sine qua non for understanding the reason why the spirit is disturbing the living. The solution to present misfortunes is very often hidden in the past (Buyandelger 2007, 2013; Swancutt 2008). Specific "oral history" practices pro202 duce dozens of micro-histories that are permanently remaking the Soviet past, and the period of colonization, into Hunnic times, and reassemble the indigenous population with the land. What is worth noticing is that all those micro-histories are based on personal and affective relations to the past. Unlike in academic history, dead persons have amazing agency; Buryat origin spirits (ongons, ug garbal) and angry, wayward souls of the people who died brutal deaths (shütkher, bokholdoi) put forward demands, prosecute or help the people, bring and take away sickness, establish sacred places, eat, smoke and drink vodka offered to them. Time loses its linearity and the past is constructed on the basis of kinship. As we can see, urban shamans play a significant role in the process of indigenization of urban space and time.

Any discussion about the past and tradition always refers to time and temporality. Using modern categories (tradition, 
history, and heritage) and pre-modern forms (rituals, dreams, ghost talk), shamans have established the new collective perception of the city, and placed its inhabitants in temporal frames. They inverse the modernist progressive New Time (Koselleck 2004, 222-54) and install their own regressive temporality, whereby native inhabitants of Ulan-Ude exercise their right to the city by placing it in a wider, indigenous time frame. Unlike in Eliade's idealistic theory of shamanism, myths and rituals are not only vehicles that transport the participants back to the world of origins, the world of events that took place "in that time" - in illo tempore (Eliade 1964). Contemporary shamans use those vehicles also to travel along the axis of linear time into the past and establish ethnic boundary markers which allow for appropriating the city and setting up a division into hosts (Buryats, Evenks) and incomers (Russians).

\section{CONCLUSION}

A former provincial town - a colonial hub on the southeastern frontier of the Russian Empire - was transfigured by communists into the capital of the Buryat Republic. Since about 2000, one can observe yet another transformation of Ulan-Ude, characterized by symbolic and demographic indigenization of the urban space. This process is accompanied by attempts to take possession of the city's past by acts of narrative and performative subversion. The date of the city's origin has been moved back from 1666 to the Hunnic period. Thus, symbolic decolonization of the past is achieved and the Russian urbanites are relegated 
to the status of strangers. ${ }^{6}$ At the same time, the native elites remain loyal to the state and to their Soviet past. Buryat culture within the urban realm has undergone a shift toward ethnic symbolism and commoditization. A visible manifestation of this tendency is the new ethnic style in urban architecture as well as indigenous place-making and lieux de mémoire that establish a native affection to the city and intimacy with its past.

\section{WORKS CITED}

Agnew, John A. 2011. "Space and Place.” In The SAGE Handbook of Geographical Knowledge, edited by J. Agnew and D. Livingstone, 316-30. London: Sage.

Badmaeva, Larisa B. 2005. Iazyk buriatskikh letopisei [The language of Buryat chronicles]. Ulan-Ude: Izdatel'stvo BNTs SO RAN.

Basu Thakur, Gautam. 2016. Postcolonial Theory and Avatar. New York, London: Bloomsbury Publishing.

Batomunkuev, Sergei. 2003. "Buryat Urbanisation and Modernisation: A Theoretical Model Based on the Example of Ulan-Ude.” Inner Asia 5 (1): 3-16.

Bauman, Zygmunt. 2017. Retrotopia. Cambridge: Polity Press.

Breslavskii, Anatolii S. 2012. Postsovetskii Ulan-Ude: Kul'turnoe prostranstvo i obrazy goroda (1991-2011 gg.) [Post-Soviet Ulan-Ude: Cultural space and images of the city (1991-2011)]. Ulan-Ude: Izdatel'stvo Buriatskogo gosuniversiteta.

Bulutov, Oleg. 2012. "Ulan-Ude - eto Udyn Adag." Buriatiia newspaper, June 13. Accessed March 8, 2016. http://burunen.ru/projects/detail.php?ELEMENT_ID=522

Buyandelger[iyn], Manduhai. 2007. "Dealing with Uncertainty: Shamans, Marginal Capitalism, and the Remaking of History in Postsocialist Mongolia." American Ethnologist 34 (1): 127-47. https://doi.org/0.1525/ae.2007.34.1.127

Buyandelger, Manduhai. 2013. Tragic Spirits: Shamanism, Memory, and Gender in Contemporary Mongolia. Chicago: University of Chicago Press.

Chakars, Melissa. 2014. The Socialist Way of Life in Siberia: Transformation in Buryatia. Budapest: CEU Press.

Chakars, Melissa, and Elisabeth I. Sweet. 2018. "Disassembledge in the Siberian City of Ulan-Ude: How Ethnic Buryats Reconstruct Through Time and Space." In Disassembled Cities: Social and Spatial Strategies to Reassemble Communities, edited by E. I. Sweet, 156-74. New York: Routledge.

\footnotetext{
${ }^{6}$ This does not pertain to quasi-ethnic groups of long-timers (Old Believers, Karyms, Gurans), who managed to create strong internal social networks.
} 
Comaroff, John, and Jean Comaroff. 2009. Ethnicity, Inc. Chicago: Chicago University Press.

Connerton, Paul. 2008. "Seven Types of Forgetting." Memory Studies 1: 59-71. https:// doi.org/10.1177/1750698007083889

Eliade, Mircea. 1964. Shamanism: Archaic Techniques of Ecstasy, translated by Willard R. Trask. Princeton: Princeton University Press.

"Fil'm o gunnakh" [A film about the Huns]. n.d. YouTube website. Accessed August 15, 2019. https://www.youtube.com/watch?v=jyr3e30vBCw

Gluckman, Max. 1954. Rituals of Rebellion in South-East Africa. Manchester: Manchester University Press.

Guggenheim, Michael. 2009. "Building Memory: Architecture, Networks and Users." Memory Studies 2 (1): 39-53. https://doi.org/10.1177/1750698008097394

Harvey, David. 2008. "The Right to the City.” New Left Review 53: 23-40.

Hobsbawm, Eric. 1983. "Introduction: Inventing Traditions." In The Invention of Tradition, edited by E. Hobsbawm and T. Ranger, 1-14. Cambridge: Cambridge University Press.

Humphrey, Caroline. 2002. The Unmaking of Soviet Life: Everyday Economies after Socialism. Ithaca, London: Cornell University Press.

Hürelbaatar, Altanhuu. 2007. "The Creation and Revitalisation of Ethnic Sacred Sites in Ulan-Ude Since the 1990s." In Urban Life in Post-Soviet Asia, edited by C. Alexander, V. Buchli and C. Humphrey, 136-56. London, New York: University College London Press.

Khobrakov, Tsybik. 2009. Metodika meditativnogo postroeniia lichnoi stupy v praktike nekotorykh vidov vostochnykh boevykh iskusstv [Methods of meditative construction of personal stupas in selected varieties of Eastern martial arts]. Ulan-Ude: Tsentr osvoeniia vremeni zhiznennogo rosta.

Koselleck, Reinhart. 2004. Futures Past: On the Semantics of Historical Time, translated by Keith Tribe. New York: Columbia University Press.

Kotkin, Stephen. 1995. Magnetic Mountain: Stalinism as a Civilization. Berkeley, Los Angeles: University of California Press.

Li, Yang, and Geoffrey Wall. 2014. Planning for Ethnic Tourism. Farnham: Ashgate Publishing.

Mitupov, Konstantin. 2002. “Gruppirovki semidesiatykh: Vospominanie-kommentarii k stat'e A. Badmaeva" [Gangs of the 1970s: A reminiscence-comment to A. Badmaev's article]. Vestnik Evrazii 1: 105-10.

Nathan, Dev, Govind Kelkar, and Pierre Walter, eds. 2004. Globalization and Indigenous Peoples in Asia: Changing the Local-Global Interface. New Delhi: SAGE Publications.

Nora, Pierre. 1989. "Between Memory and History: Les lieux de mèmoire." Representations 26: 7-24.

Nowicka, Ewa, and Robert Wyszyński. 1996. Lamowie i sekretarze: Poziomy więzi społecznych we wspótczesnej Buriacji [Lamas and secretaries: Levels of social bonds in modern Buryatia]. Warszawa: Wydział Filozofii i Socjologii Uniwersytetu Warszawskiego.

Quijada, Justine B., Kathryn E. Graber and Eric Stephen. 2015. 'Finding 'Their Own' Revitalizing Buryat Culture Through Shamanic Practices in Ulan-Ude." Problems of Post-Communism 62 (5): 258-72. https://doi.org/10.1080/10758216.2015.1057040 
Sántha, István, and Tatiana Safonova. 2011. "Pokazukha in the House of Culture: The Pattern of Behavior in Kurumkan, Eastern Buriatiia." In Reconstructing the House of Culture: Community, Self, and the Makings of Culture in Russia and Beyond, edited by B. Donahoe and J. Otto, 75-96. New York: Berghahn Books.

Slezkine, Yuri. 2000. "The USSR as a Communal Apartment, or How a Socialist State Promoted Ethnic Particularism.” In Stalinism: New Directions, edited by S. Fitzpatrick, 313-47. London, New York: Routledge.

Smyrski, Łukasz. 2016. "Kinship, Ethnicity and Landscape: The Contexts of Ethnic Boundaries in Southern Siberia, Mongolia and Inner Mongolia.” Ethnologia Polona 36: $13-30$.

Swancutt, Katherine. 2008. "The Undead Genealogy: Omnipresence, Spirit Perspectives, and a Case of Mongolian Vampirism." Journal of the Royal Anthropological Institute 14 (4): 843-64.

Szynkiewicz, Sławoj. 2007. "Lekceważone ludy" [Disdained peoples]. In Ludy tubylcze: Czwarty świat, dziedzictwo kolonializmu, skanseny świata czy partnerzy narodów, edited by A. Bartkiewicz, 23-30. Warszawa: Wydawnictwo Comandor.

Vasil'ev, Bakalin. 2015. 'Ust'e Udy - sviatoe mesto, gde dolzhny stoiat' tol'ko dva sviashchennykh Oboo i nichego bol'she" [The mouth of Uda is a sacred place, where only two sacred Oboo should stand and nothing else]. Babr24 website, May 26. Accessed August 15, 2019. http://babr24.com/bur/?IDE=136059

Wood, Robert E. 1984. "Ethnic Tourism, the State and Cultural Change in Southeast Asia." Annals of Tourism Research 11 (3): 353-74. https://doi.org/10.1016/01607383(84)90027-6

Zhimbiev, Balzhan. 2000. History of the Urbanization of a Siberian City: Ulan-Ude. Cambridge: White Horse Press. 


\title{
Darima Bajko
}

Independent Researcher

\section{ECOLOGICAL DISCOURSE IN THE CROSS-BORDER REGION OF THE SELENGA RIVER IN RUSSIA AND MONGOLIA}

\begin{abstract}
The article traces the development of ecological discourse in a border region of Russia and Mongolia. It is a brief review of major stages of this discourse as reflected by the case of cross-border water resources of the Selenga River basin that merges politically demarcated lands into a single region. The article sets out to establish whether the problem of water resources appeared in past narratives, when exactly the ecological component of the border came into being and how it has changed perspectives on local cultures.
\end{abstract}

Keywords: ecology, borderland regions, water resources, modernity, Russia, Mongolia

\section{INTRODUCTION}

A survey of the historiographic literature reveals that the main discourses that are studied in connection with the MongolianRussian border concern the trade routes, economic matters associated with pastures, and political issues. Few researches examine the "ecological" aspect of this border. This article 


\section{Darima Bajko}

sets out to address this shortcoming by tracing the ecological discourse in the cross-border region of the Selenga River in Mongolia and Russia, focusing on when and how it came into being. I will briefly outline the history of the border and the narratives it was associated with throughout the recent history. In this context, I claim that the ecological component was a quite recent phenomenon, connected with the post-Soviet period of transformation. I will describe how it was implemented in institutions, present the inspirations of the ecological activists, and show how this ecological discourse impacted the reinterpretations of various cultural phenomena. The article is based on an analysis of source literature, legal documentation and 208 interviews with a variety of experts who specialize in ecology in the Russian-Mongolian borderland.

\section{THE HISTORY OF THE BORDER}

The border between Russia and Mongolia appeared about 300 years ago as the border between the Russian and Qing Empires. Throughout history, its geopolitical significance and permeability were always changing - so much so that it actually is a big question nowadays when the border was de facto established. In the academic and public circles of Buryatia, various dates circulate which could be counted as the beginning of state demarcation. In this part, I would like to deliberate on this issue to understand what discourses and topics have been associated with the border.

The "official" date of inclusion of ethnic Buryat lands into the Russian state is often contested and evokes numerous 
discussions. The most heated of them arose around the date of the recent celebration of the border's official anniversary, commemorating the year 1661, when the first Cossack fortifications (ostrogs) were built in various points of the region. However, as many scholars note, the allocation of the Cossak ostrogs needs not imply that the territory was perceived as a borderland by local communities. It was rather the beginning of the growing Russian influence in the region. The final course of the border was eventually set by a series of treaties with the Qing Empire. It was not until the Treaty of Nerchinsk (1689) that the project of the border began to shape the local geography and population. As was inevitable, the official border demarcation could hardly be identical to the people's perceptions of the border. During this initial period transborder migrations were still very active and only with the Treaties of Bura and Kiakhta (1727-1728) did the border become more and more restricted.

Thus, a clear territorial demarcation of the Russian and Qing Empires began in the first half of the 18th century. In the 19th century, there were various geopolitical reconfigurations and changes connected with the border in Northern Manchuria. The imperial centers naturally strove to mediate and coordinate all the connections across the borders; however, the regions experienced most of their own contacts outside of these official regulations, which did not fully account for borderland realities (Popov 2015, 28-9).

The 20th century saw significant changes in the geopolitical map of the region. In 1921, Outer Mongolia gained independence, though it came to depend on close relations with the newly 


\section{Darima Bajko}

born Soviet state in the north. The same geographical region developed starkly different attitudes to the significance of different borders. While the Russian-Mongolian border became more open and accessible with time, the Chinese side of the border became more militarized. Some scholars even call Mongolia the buffer state of the region (Bulag 1998). This position predetermined the strategy of its foreign and domestic policy, focused on the closest cooperation with the Soviet Union, which was reflected in the 1921 Agreement between the government of the Russian Soviet Federative Socialist Republic and the Mongolian Republic on the establishment of friendly relations between Russia and Mongolia.

Mongolia's Soviet-type modernization process began a new stage in the border relations with Russia. This included an extension of road and railway communication between the countries, and the development of mining industry in both Mongolia and Russia. Scholars asses this period in an ambivalent way. On the one hand, the ideology of progress and development did indeed lead to positive attitudes among the population (Tangad 2013, 62-3), but on the other, various researchers cite extensive environmental issues in the region caused by the policies of that time (Humphrey and Sneath 1999; Sneath 2009).

In some ways, one could say that this was the period when the ecological discourse began. According to Melissa Chakars, the ecological movement in Siberia was initiated by ethnic Russians in the 1960s. Partly connected with the Village Prose movement, it revealed the social and environmental consequences of the modernization process (Chakars 2014, 232-3). Its activity, 
however, had little impact on state-level decisions, which in any case were few in number. The factor that significantly influenced the development of the Soviet-Mongolian relations in the field of protection and use of transboundary waters was the 1966 adoption of the Helsinki Rules on the Uses of Waters of International Rivers based on the principle of equitable management by basin states, put forward by the International Law Association. The formation and development of international water law found reflection in the development of national water laws of the Soviet Union and Mongolia, most notably the adoption in 1972 of the Water Code in the Soviet Union, and in 1974 of the Mongolian Law On Water, which for the first time in the history of the two states reflected the notion of "border water bodies." Then, in 1974, agreement was signed between the Government of the Soviet Union and the Government of the Mongolian People's Republic on rational management and conservation of the Selenga. It was then that political foundations were laid for the modern Russian-Mongolian cooperation in the field of protection and use of transboundary waters.

\section{THE ECOLOGICAL COMPONENT OF THE BORDER}

The events associated with the systemic transformation and collapse of the Soviet Union and the fall of the communist government in Mongolia in the late 1980s and early 1990s changed the established principles of political, economic, cultural and military cooperation between the countries of the 


\section{Darima Bajko}

former socialist bloc, including Russia and Mongolia. Various reports note that there was a cooling, both at the official level and at the level of attitudes of certain parts of Mongolian society to Russia (Ganzorig 2001; Erdenebat 1998, 80). In the late 1990s, the relations between Mongolia and China increased. The countries, which have a common border of about 4,700 kilometers in length and common transboundary water bodies, signed an Agreement on the Protection and Use of Transboundary Waters in 1994. China has become one of the main external partners of Mongolia, especially in the mining and manufacturing industries (Bazarov 2009). Nevertheless, during this period, Mongolia's foreign policy was based on multi-vector principles (Tsyrenova 2012, 205), and consequently, starting from the second half of the 1990s, restoring ties between Russia and Mongolia at various levels was the primary task on the agenda.

A new post-socialist phase in interstate relations was ushered in with the Treaty on Friendly Relations and Cooperation between the Russian Federation and Mongolia of January 20, 1993. The agreement stipulated a partnership between the two states in various spheres, including the ecological one. Its important point was that cooperation in the field of environmental protection was planned within the framework of international rules and regulations, of the UN system and of other international organizations. This trend, promoted largely by cardinal changes within the political systems of the Russian Federation and Mongolia, was also reflected in the relationship in the field of protection and use of transboundary waters. Tat'iana Tsyrenova's analysis of the political documents signed by the 
heads of the Russian Federation and Mongolia (Tsyrenova 2012, 206) shows that, along with the special interest of the two states in political and economic cooperation, the environmental sphere has remained an object of constant attention of the parties, with water relations having a special significance. Specifically, the Declaration on the Development of a Strategic Partnership between the Russian Federation and Mongolia, indicates the need for close cooperation in this area. The document notes that "the parties will concentrate joint efforts to protect transboundary waters, preserve biodiversity, will promptly notify each other and exchange information in the event of transboundary emergencies of natural and man-made origin" (Deklaratsiia 2009). It was also decided that integrated ecological studies of the Baikal and Khubsugul Lakes be continued, and that the status of a transboundary protected zone be granted to Ubsunur and Onon-Sokhond Lakes.

At the same time, the fundamental changes in the political institutions of Russia and Mongolia in the early 1990s caused a transformation of the Russian-Mongolian interstate interaction. Significant differences between political institutions in the Russian Federation and Mongolia emerged, including a change of the subjects that took foreign policy decisions. In Mongolia, owing to the unitary nature of its political structure, the parliament, or the Great State Khural, became the main subject formulating the foreign policy prerogatives. In Russia, the main subject in the foreign policy sphere is the government. The change in the main actors of state management of transboundary water bodies occurred against the backdrop of internal political 


\section{Darima Bajko}

instability in the two states. Also, the centrifugal processes that took place at that time in both countries strengthened the role of non-governmental organizations in the protection and use of water resources, which revealed their inefficiencies. All this affected the development of mechanisms of interstate cooperation regarding transboundary waters. But despite the destruction of the existing hierarchy of power, the ineffective foreign policy of Russia and Mongolia, and changes in the political, economic and other spheres of Russian and Mongolian societies, the Russian-Mongolian interstate interaction was still deemed significant. This was confirmed by an agreement signed in 1995 between the Government of the Russian Federation and the 214 Government of Mongolia On the Protection and Management of Transboundary Water. The 1995 Agreement singled out main directions for the conservation of transboundary basin ecosystems, the use of water resources, and preventing water pollution and reduction in water availability. Within the framework of the Agreement, the following activities are carried out: studies of hydrochemistry, hydrobiology and processes in river beds; joint research, assessment and planning in flood management; joint water monitoring and pollution prevention; development of the concept of water resources management in river basins; development of joint pollution control standards and procedures; exchange of information on planned measures in the field of water resources management. Thus, ecological discourse has become a strong component of interstate relations in the region. 
ECOLOGICAL DISCOURSE IN THE CROSS-BORDER REGION...

\section{WATER: THE CASE OF THE SELENGA RIVER}

In December 1996, Lake Baikal was recognized by UNESCO as a World Natural Heritage site. This imposed on Russia a legal, economic and ethical responsibility to preserve the entire area. The fulfillment of these obligations towards Baikal largely depends on Russia's interaction with Mongolia, as the main tributary of Baikal is the transboundary Selenga River, which brings to it an average of about 30 cubic kilometers of water a year, amounting to half the total inflow to the lake. Of this, around $14-15$ cubic kilometers a year, or about $45-50 \%$ of the Selenga inflow, comes from the large part of the Selenga catchment area that is situated on the territory of Mongolia, and is thus not subject to the provisions of Russian legislation. Therefore, ecological safety of Baikal cannot be ensured exclusively within the framework of the Russian law. Full protection of Baikal's main inflow and its entire ecosystem is impossible outside the context of Russian-Mongolian cooperation in the field of protection and use of transboundary waters and of environmental protection more generally. These issues are also of vital importance to the Mongolian side, since the problem of the distribution and sharing of transboundary waters in the context of limited water resources affects the vital spheres of the economy. Under these circumstances, interaction with Russia in the use and protection of water resources allows for exchanging experience in the field of protection and use of water resources, while also acting as a balancer of Mongolia's national interests and a means of preserving its sovereignty in the context 


\section{Darima Bajko}

of a multi-vector foreign policy, in which neighboring China is a major actor (Iaskina 2002). The interaction of Russia and Mongolia in the field of Baikal protection is currently based, on the one hand, on international legal acts, and on the other hand, on the main provisions of the 1995 Agreement.

Since 2014, the publics of Russia and Mongolia, including the scholarly ones, have been discussing the project of constructing the Shuren Hydroelectric Power Station on the Mongolian section of the Selenga, and the problem of the shallowing of Lake Baikal that this might lead to. The history of this project began in 1965, when nine-year-long research work was undertaken, as a result of which the State Production Committee for 216 Energy and Electricity of the USSR and the All-Union Scientific Research and Design Institute for Electric Supply in Agricultural and Other Consumer Areas identified 27 river sites in Mongolia suitable for the construction of hydroelectric facilities, including hydroelectric power stations. At the same time, in Mongolia itself, the Politburo of the Central Committee of the country's Communist Party was discussing this topic, with an intention to begin the construction of hydroelectric power stations on the rivers Selenga, Orkhon and Egiin. Due to a variety of reasons, including financial ones, the implementation of the project to build a hydroelectric power station in Mongolia was postponed until the beginning of the 1990s, and then until 2006-2007. The third attempt to implement the construction of the hydropower plant began in 2014, when Mongolia's Prime Minister Norovyn Altankhuiag and Energy Minister Mishigiin Sonompil initiated this project, since the Mongolian power system could no longer 
withstand more than $300 \mathrm{MW}$ of load difference (Odkhuu 2016). A review of the literature regarding the project reveals a predominantly negative attitude on the Russian side. This has to do with the regulatory framework being insufficient to tackle transboundary environmental problems associated with Lake Baikal. The central issue consists in the fact that the Selenga River (the main water tributary of Lake Baikal) is not included in the protected Baikal ecological territory, since most of the upper reaches of the river are located on the territory of Mongolia. Thus, the Mongolian section of the Selenga River is almost inaccessible to Russians in case of environmentally harmful activities, which, of course, can disrupt the ecology of the entire Baikal region. This becomes an even greater danger in view of the plans to build another hydropower station along with water dams on the Mongolian side of the river. On the other hand, this project is certainly relevant for Mongolia, which apart from energy problems, is experiencing the processes of desertification that are a threat to livestock.

During the period of March 20-31, 2017, public consultations were held in 10 municipalities of the Republic of Buryatia to discuss the technical designs of two projects: the Shuren Power Station and the related regulation of the flow of the Orkhon River and construction of a complex of reservoirs. More than 1,300 of the participants were against the implementation of these projects. Russian environmentalists actively objected, pointing to ecological risks for Baikal. The result of the consultations was a draft decision, according to which the Mongolian side was recommended to consider the protocols of 


\section{Darima Bajko}

the hearings as a public material inalienable from the project documentation. The document also urges the Mongolian side to elaborate in more detail alternative options that do not require the construction of dams on the Selenga and its tributaries. In sum, the Russian side treats as a serious threat to its environmental security the implementation of scenarios that accelerate the development of the Mongolian economy, including the construction of the Shuren hydropower station on the mainstream of the Selenga River and the transfer of part of the Orkhon River further south. The Mongolian side in this conflict claims in its turn that ecological discourse camouflages the political interest of the Russian state in controlling energy resources in the region.

In this example, we can see a widespread network of economic and political interrelations equally affected by environmental problems. This is true within the framework of one state, but at the same time problems arise across state borders (in both the Russian Federation and Mongolia), which seem even greater. The situation of the Baikal region shows that the geopolitical interactions between mutually recognized sovereign national societies may be insufficient in the face of the natural processes that constitute an important component in a cross-border dialogue in which "ecology" comes to be a major topic.

\section{INSTITUTIONALIZED ECOLOGY}

It is safe to assume that the formation of a distinct ecological ideology took place mainly in the post-Soviet period. This could be seen in how educational institutions adapted their curriculum 
in this sphere. In 1993, the Center for Environmental and Humanitarian Research and Education was formed in Buryatia and later transformed into the Faculty of Ecology and Humanities at the East Siberian State University of Technology and Management in Ulan-Ude. In 1996, the Buryat State University's Department of Ecology and Life Safety began training specialists in Environmental Protection and Rational Use of Natural Resources, and since 2011, bachelors and masters of science have also been trained in Energy and Resource-Saving Processes in Chemical Technology, Petrochemicals and Biotechnology.

The Department of Geography and Geoecology of the Buryat State University was established in 2015 as a result of the merger of the Department of Economic and Social Geography and the Department of Physical Geography (established 1988). The new department conducts research in the field of socio-economic, demographic and ecological development of the Baikal region and border territories. The Buryat State Agricultural Academy also trains specialists in agro-ecology. Most of these educational and organizational shifts took place in the post-Soviet period.

The school curricula were also reformed to meet the ecological needs and trends in the country. In the Federal Law on Environmental Protection of January 10, 2002, Chapter 13 titled "Fundamentals of the Formation of Ecological Culture" Article 71 states that

for the formation of ecological culture and professional training of specialists ... a system of universal and comprehensive environmental education is established, including preschool ${ }^{1}$ and general school education,

\footnotetext{
${ }^{1}$ The mention of preschools was removed in a 2013 revision of the Law.
} 
secondary and higher vocational education, postgraduate education and professional retraining, professional development of specialists, as well as of dissemination of environmental knowledge, including through the mass media, museums, libraries, cultural institutions, environmental institutions, [and] sport and tourism organizations (Federal'nyi zakon 2002).

In Article 74 the need for universal environmental education of the population is defined, to be implemented by a host of organizations, including all levels of government of the Russian Federation, local authorities, and the mass media. Thus, since January 2002, mandatory environmental education of the younger generation, students and of the entire population of the Russian Federation has been legislatively established. In Buryatia, a development strategy was approved for continuous ecological education and formation of ecological culture in the republic in 2012-2016. The environmental specialists of the region whom I interviewed added that ecological traditions - defined as folk knowledge and skills accumulated in the process of interaction with nature - should likewise be legislatively inscribed into the multi-level system of environmental education. They also noted the disunity of environmental education systems and the fragmented work on the popularization of ecological traditions. In the next part, I would like to deliberate on the interpretation of the "tradition" in the newly emergent "ecological" aspect.

\section{REINTERPRETATION OF TRADITION}

According to Chakars, the ecological movement in Buryatia was initiated by ethnic Russians, primarily the abovementioned movement of the Village Prose writers: 


\section{ECOLOGICAL DISCOURSE IN THE CROSS-BORDER REGION...}

their movement likely influenced Buryat writers who also chose to express concern about their natural environment. Various Buryat authors wrote stories and poems about the relationship between humans and nature and sometimes criticized Soviet economic development and its consequences to the land, and in particular, to Lake Baikal. Writers, such as Mikhail I. Zhigzhitov, examined the results of fishing in Lake Baikal as well as overhunting animals such as the sable in his work. Others, such as Dasha-Demberel Dugarov, explored both environmentally responsible and irresponsible hunting practices in Siberia in his collection of stories and poems titled Black Sable that was published in 1969. However, these stories were also part of a larger all-union environmental movement and much of the literature promoting protection, including that of Lake Baikal, was produced by non-Buryats (Chakars 2014, 185).

The ecological traditions were not on the agenda of national ideology and nativist movement was not much developed in the Buryat context (Chakars 2014, 232-3). With the introduction of the ecological discourse in Buryatia, however, the local traditions are being constantly reinterpreted. In order to trace this, I conducted a series of interviews with professional ecologists and scholars specializing in environmental issues. I sought to learn how they saw the role of traditions in the ecological sustainability of the region. The experts to whom I talked unanimously interpreted the local tradition as something virtually extinct but worth reviving:

Those cardinal socio-political and socio-economic changes that occurred in the Baikal region over the years of the domination of technogenic civilization and social production have led to ecological traditions having ceased to be the leading regulators in the relationship between nature and society (Budaeva 2003, 120).

The scholars claim that in terms of attitude to nature, traditional culture is uniform on both sides of the border. 


\section{Darima Bajko}

The experience of generations living in direct dependence on the local environment made for harmonious relations with nature, forming traditions and customs which, it is maintained, ought to be introduced into today's socio-economic relations. This knowledge in the field of traditional environment management was transmitted from generation to generation and is often seen as a panacea for environmental ills facing today's world.

The scholars attribute some of the ecological tradition of balance with nature to traditional pastoral economy. Its minimal usage of resources is often contrasted to the modernist industrial extravagancy. The tradition of nomad livestock farming - which excludes trampling of soils, as is the case with stall farming contributes to the conservation of the vegetative cover of the earth. The hunting season was likewise strictly observed for many centuries according the principle of reasonable extraction. According to the experts, this led to the conservation of a number of wildlife populations, many of which are now at a stage of extinction. The word "indigenous" (Rus. korennoi) is an increasingly important element in the vocabulary of ecological discourse. The cultures of the "indigenous" populations are said to be based on minimalism with regard to what they receive from nature, while modern society strives to get most benefits with least diligence. An unconscious understanding of the fragility of the environment leads these populations to implement a system of strict limitation of time, place and scale of hunting, fishing and harvesting of wild plants. Other examples of environmental measures in traditional cultures include the technology of collecting medicinal plants, careful 
ECOLOGICAL DISCOURSE IN THE CROSS-BORDER REGION...

treatment of water sources, and rituals and customs closely related to natural features and lifestyle.

The religious background of indigenous cultures is also deemed a source for ecological ethics. Buddhism and shamanism, despite their doubtful environmental friendliness, are considered to contain environmental ethic. The Buddhist and shamanist ceremonies and rituals are seen as propagating the proper ecological attitude to nature. These "ecological" practices include prohibitions from digging the earth, cultivating it, moving stones, and changing river beds. The worship of nature, attention paid to the processes taking place in it, organizing human activities in accordance with it - all inflict minimal damage to the environment.

Thus, expert evaluations allow us to formulate the basic idea that traditional culture is seen as the ideological resource for environmental ethics: for millennia, the ecological traditions of the regional population's spiritual life have produced a kind of ideological conception, formed on the basis of a utilitarian and rational synthesis of human relationships with certain aspects of the natural environment and landscape in the zone of Baikal's influence and adjacent lands. This ideological concept is related to the entire way of life and to the relationship to nature and its parts, among which heaven and earth, the heavenly bodies, and water and fire are the most revered. The process of formation and development of ecological traditions is, in fact, the history of shaping the relationship of man to nature. In their development, ecological traditions have inevitably passed a number of stages and have changed more than once, depending on the needs of 


\section{Darima Bajko}

society and the possibilities of their satisfaction. Contemporary environmental management experts deem it desirable to rely on traditional values, proven over centuries, especially since they unite related peoples living in the Russian-Mongolian cross-border area.

\section{CONCLUSION}

One of the main claims of this article has been that the ecological component of the transboundary relations between Mongolia and Russia was a phenomenon connected with the post-Soviet period of transformation. I have reviewed the various other contexts of these relations and tried to trace how the ecological discourse reinterpreted various other phenomena, such as tradition, culture, and modernization. Due to the lack of an effective legislative base, the only possible channel of protest is now being sublimated in the sphere of tradition, identity and nativist ideology. I see this in numerous comments on Internet forums, publications, and opinions that call for a return to traditional models of human-nature relations in the culture of Mongolian peoples. Despite the current shape of the state border, the territories of the Baikal region and Mongolia share common cultural and historical perceptions of the natural landscape as not just a passive object for manipulation, but as an active subject of the human social world. This part of identity is disputed under the pressure of the models of industrialization and modernization which began in the Soviet era and have led to sharp environmental changes. A very topical 


\section{issue, which certainly warrants in-depth studies on both sides of the border, are changes in cultural values resulting from market demands and their impact on identity.}

\section{WORKS CITED}

Bazarov, Viktor B. 2009. "Sovremennye mongolo-kitaiskie otnosheniia" [Contemporary Mongol-Chinese relations]. Vlast' 11: 79-82.

Budaeva, Tsytsyk B. 2003. "Vozrozhdenie ekologicheskikh traditsii Buriat" [Revival of Buryat ecological traditions]. Sotsiologicheskie issledovaniia 6: 120-3.

Bulag, Uradyn E. 1998. Nationalism and Hybridity in Mongolia. Oxford: Clarendon Press. Chakars, Melissa. 2014. The Socialist Way of Life in Siberia: Transformation in Buryatia. Budapest: CEU Press.

Deklaratsiia o razvitii strategicheskogo partnerstwa mezhdu Rossiiskoi Federatsiei i Mongoliei [Declaration on the development of strategic partnership between the Russian Federation and Mongolia]. 2009. Concluded August 25. Seichas.ru website. Accessed August 15, 2019. https://www.lawmix.ru/abrolaw/1824

Erdenebat, Balgan. 1998. "Kharakter i tendentsii razvitiia voennykh otnoshenii Mongolii s zarubezhnymi stranami v usloviiakh novoi geopoliticheskoy obstanovki" [The character and development tendencies of Mongolia's relations with foreign states in the conditions of the new geopolitical situation]. In Mongoliia: Aktual'nye voprosy natsional'noi bezopasnosti, edited by R. A. Karimov, 79-90. Moskva: Rossiiskii institut strategicheskikh issledovanii.

Federal'nyi zakon ot 10.01.2002 N 7-F3 "Ob okhrane okruzhaiushchei sredy" [Federal Law No. 7-F3 of January 10, 2002, “On Environmental Protection”]. 2002. Konsul'tantPlius website. Accessed August 15, 2019. http://www.consultant.ru/ document/cons_doc_LAW_34823/

Ganzorig, D. 2001. "K voprosu ob uregulirovanii zadolzhennosti Mongolii pered Rossiiskoi Federatsiei” [On the issue of settling Mongolia's debt to the Russian Federation]. In Rossiia i Mongoliia: Novyi vzgliad na istoriiu vzaimootnoshenii $v$ XX veke, edited by Ts. Batbaiar et al., 220-9. Moskva: Institut vostokovedeniia RAN. Humphrey, Caroline, and David Sneath. 1999. The End of Nomadism? Society, State, and the Environment in Inner Asia. Durham: Duke University Press.

Iaskina Galina S. 2002. Mongoliia $i$ vneshnii mir [Mongolia and the outside world]. Moskva: Institut vostokovedeniia RAN.

Odkhuu, Durze. 2016. "My mozhem sohkranit' Baikal vmeste” [We can preserve Baikal together]. Tayga.info website, May 10. Accessed August 15, 2019. https:// tayga.info/128439.

Popov, Anton V. 2015. “Tsinskoe zakonodatel'stvo XVIII-pervoi poloviny XIX v. ob administrativnom rezhime khalkhaskogo uchastka russko-mongol'skoi granitsy" 
[18th to early 19th century Qing law on the administrative regime of the RussianMongolian border]. Mongolica 15: 27-38.

Sneath, David. 2009. "Reading the Signs by Lenin's Light: Development, Divination and Metonymic Fields in Mongolia." Ethnos 74 (1): 72-90.

Tangad, Oyungerel. 2013. Scheda po Czyngis Chanie: Demokracja po mongolsku [Genghis Khan's legacy: Democracy Mongolian style]. Warszawa: Trio.

Tsyrenova, Tat'iana B. 2012. "O politicheskikh osnovakh vzaimodeistviia Rossii i Mongolii v oblasti okhrany i ispol'zovaniia vodnykh resursov" [On the political foundations of Russian-Mongolian cooperation in the field of water resources protection and use]. Vestnik Buriatskogo gosudarstvennogo universiteta 6: 204-7. 


\title{
Nikolai Baikalov
}

ORCID 0000-0002-2511-9003

Banzarov Buryat State University

\section{BAM AND BAMERS: \\ PECULIARITIES \\ OF IDENTITY FORMATION}

\begin{abstract}
The regional identity of the population of the Baikal-Amur Region formed over several decades: from the beginning of the Baikal-Amur Railway Mainline (BAM) construction in the 1970s and 1980s and up to the post-Soviet crisis of the 1990s. The Soviet government attracted people to desolate northern territories with high wages, special benefits, and moral incentives. As a result, a separate socio-cultural community of the "Bamovtsy" (BAMers) was formed. The BAM identity was distinguished by heterogeneous hierarchies of subidentities organized on the basis of territorial, chronological, professional, ethnic and other characteristics. The completion of the BAM construction and the disintegration of the Soviet state led to the isolation and economic degradation of BAM regions. Against this background, the Soviet past of BAM became a myth about the "golden age," which laid the foundation for preserving the former BAM identity, sought by way of many modern behavioral strategies of local residents, including protest actions, victimization, absenteeism, etc. Acting as a basis for the consolidation of local communities, this identity is transformed very slowly owing to migrations and the natural change of generations.
\end{abstract}

Keywords: Siberia, Baikal-Amur Railway Mainline (BAM), late socialism, social identity, Soviet mythology, post-Soviet period 


\section{INTRODUCTION}

The Baikal-Amur Mainline Railway (BAM), stretching for 4,300 kilometers from Lake Baikal to the Pacific Ocean, was the last mega-project of the Soviet state. The main period of construction occurred in 1974-1989, although the completion of works took place only in 2003, after the tunneling through Severo-Muisk ridge had been finished. The Soviet press often called the mainline the "project of the century" (stroika veka) or "the Second Trans-Siberian railroad" (Vtoroi Transsib), trying to emphasize the scale and epochality of the undertaking. Combining expectations of a revitalization of late socialism ("road to the future") and exposition of the stalemate of the Soviet model of development ("monument to stagnation"), the BAM took a special place in the contemporary history of the USSR.

This paper is devoted to the analysis of the formation and functioning of the regional identity of the BAM builders and residents of settlements along the railway, which is reflected in their designation, and self-name, "Bamovtsy" (BAMers). Under the enduring influence of the Soviet propaganda from the main period of BAM construction, this definition, as well as the complex of representations associated with it, still forms the basis for consolidation of the majority of population in the BAM region, which occupies northern territories of Irkutsk Oblast, Republic of Buryatia, Zabaikal'skii Krai, and Khabarovsk and Amur regions.

The material that formed the basis for the article was collected during my ethnographic fieldwork in towns and settlements 
along the Western section of the BAM in 2005-2018. I used the methods of overt observation, and semi-structured and unstructured (biographical) interviews with builders and their families living inside or outside the BAM region. Journalistic, artistic and memoirist texts on the BAM of the Soviet and post-Soviet periods, articles in the local press, and toponymical data were also utilized in the study.

To analyze the empirical base, some approaches widely used in contemporary social science were applied. In particular, the understanding of regional social identity was promoted by the approach presented in the works of Alla Anisimova that combines the activity-focused version of the constructivist approach and the concept of "narrative identity" (so-called "combined approach," cf. Anisimova and Echevskaia 2016, 10; for more on narrative identity, cf. Anisimova and Echevskaia 2012). As she puts it, "analyzing identity from such positions implies the identification of self-description constructs in an interview's narrative structure that explain the formation of a Siberian identity from a biographical perspective, and their consistent exposition in three dimensions: social, reflexive, and temporal" (Anisimova and Echevskaia 2016, 10). ${ }^{1}$ Analyzing the history of the BAM's construction and the urbanization of the region, I use the notion of "modernization myth" (cf. Povorozniuk 2016, 2; Rozhanskii 2012). The industrial pathos of the Soviet era was replaced by a crisis and depression in the BAM settlements in the 1990s and 2000s. This led to an idealization of the past and the formation

${ }^{1}$ Unless otherwise indicated in the References section, all translations from Russian are mine - N. B. 


\section{Nikolai Baikalov}

of ideas about the "golden age" of the BAM, which shape social identifications of the population nowadays.

The article consists of four main parts. In the first part, I consider the main stages of the construction of the BAM, and discuss the conditions and prerequisites for the formation of a new collective identity of the population within the areas along the railway line. The second part describes the main components of the BAMers' identity on the basis of official and unofficial Soviet discourses. Further, an attempt is made to delineate the social boundaries of the BAM identity, as well as to reconstruct its internal hierarchy. In the final part, main directions of the transformation of the BAM identity in the 230 post-Soviet period are highlighted.

\section{HISTORY OF BAM CONSTRUCTION}

The idea of laying a railway to the Pacific Ocean through the northern extremity of Lake Baikal was not a Soviet invention. For the first time, this route was marked up during the spontaneous advancement of the Siberian pioneers of the 17th century, who, in an effort to avoid encounters with Qing China, rounded Baikal from the north. In the last third of the 19th century, the project of the northern route was discussed both when choosing the trajectory for the Trans-Siberian Railway, and as an independent line. The first exploration works, carried out in 1889 , recognized the impossibility of constructing the northern way due to difficult natural and geographical conditions. 
The Stalinist modernization project tried to solve this problem and to transform the severe nature of the North using convict labor. Construction of the western and eastern sections of the BAM was conducted by Bamlag in 1932-1938 and by the Amurlag in 1947-1953. ${ }^{2}$ However, in absence of the necessary technical equipment, the work of prisoners could not provide significant results.

The Soviet government returned to the idea of the BAM as a comprehensive project for the development of the northern territories of Siberia and the Soviet Far East in the early 1970s. A surprising urgency with which the construction of the BAM was announced in 1974, without carrying out the necessary exploration and prospecting, gave rise to many explanations: from the desire to accelerate the transit of West Siberian oil to the Pacific ports to the need to protect the eastern regions of the country in the event of a war with China. Officially, only one reason for the construction of a new railway line was announced: the development of productive forces in Siberia and the Soviet Far East through the creation of new territorial production complexes on the undeveloped and sparsely populated northern territories (Grützmacher 2012, 308).

At the same time, the previous strategy of socio-economic development of new territories, based on either coercion, labor enthusiasm, or both, gave way to a new one, related to the

\footnotetext{
${ }^{2}$ The Baikal-Amur Corrective Labor Camp (Bamlag) was a subdivision of the GULAG, which existed between 1932 and 1938 to construct the Baikal-Amur Railway. In 1938, it was disbanded into 6 railroad labor camps. The Amur Railroad Corrective Labor Camp (Amurlag) was a subdivision of the GULAG which existed between 1947 and 1953. The main types of activity of Amurlag prisoners were railway construction, mining and logging.
} 
actual recognition of the "material interests" of workers. High earnings, supplies of scarce goods and foodstuffs, accelerated construction of social and cultural objects in the builders settlements were all used to attract people to the BAM.

The most common forms of organized labor recruitment were public calls, transfers of workers from other enterprises and construction projects, redeployments of the entire construction organizations from other regions, and work placements after graduation from educational institutions. However, spontaneous migrants constituted a majority of the arrivals at the BAM. People were invested in the idea of transforming Siberia and the Soviet Far East, each solving both the existential and everyday problems involved in their own way. Some were prompted to go to Siberia by the tightness of their city apartments. Others were deeply impressed by the "smell of the taiga" promoted in the Soviet propaganda texts. People were often looking for opportunities to test socialist ideals and overcome the dual standards of Soviet reality. Channeling social activity in a controlled manner made it possible for the authorities to reduce social tensions in the European regions of the country. The mechanism of mass population movement to the vast spaces of Asian Russia was put into action without much difficulty, primarily because of the ontological predetermination of "project Siberia." According to expert estimates, more than 2 million people worked only on the western part of BAM in the first 15 years of railway construction (Kin 2016, 58).

About 300 permanent and temporary settlements and railway stations were built during the construction of the BAM. 
To facilitate this process, the Soviet leadership organized a system of patronage (shefstvo) that covered 13 Union Republics (within the USSR) and 22 autonomous administrative units of the Russian SFSR (Gordienko 1999, 49). Patronage assistance included the design and construction of permanent settlements for railway workers as well as railway stations themselves and other infrastructure facilities. The patronage republic had to provide the site with necessary building materials, as well as labor force. As a result, several building organizations with unusual names appeared, such as the LitvaBAMstroi [named after Lithuania], ArmeniiaBAMstroi, KazakhBAMstroi, LeningradBAMstroi, etc. Such a system was designed to demonstrate the international brotherhood of the peoples of the USSR, which consolidated their forces in a common impulse to build a "road to the future." According to experts' estimates, representatives of 80 nationalities were present during BAM construction (Gordienko 1999, 49). Nevertheless, most of the building divisions arrived from the Soviet republics and regions where representatives of the East Slavic peoples (Russians, Ukrainians, Belarusians) comprised a majority (Argudiaeva 1988, 22).

Despite its diversity, the population of the BAM region had some common features: a relatively young age (25-35 years) and an orientation toward temporary stay in the construction zone, and, as a consequence, willingness to accept inconvenient living conditions of the new development area. The workers also enjoyed a privileged position in comparison to ordinary Soviet citizens. The latter circumstance was expressed both in material terms (high salaries, special trade supply, possibility to buy 
a car or receive housing out of general queue) and nonmaterial terms (constant attention of the Soviet press, heroization of the builders by Soviet propaganda, regular visits of the Soviet leaders, pop stars, foreign guests). It was in such conditions that the idea of a new community, the BAMers (Bamovtsy), was formed. In the BAM region, it replaced previous Soviet construction identities, such as the "Komsomol'tsy," "Siberians," "Northerners" (Povorozniuk 2017, 143).

\section{WHO ARE THE BAMERS?}

At the center of the official image of the BAMers lay the idea of the BAM as an All-Union Komsomol Pace-Setting Project (Vsesoiuznaia komsomol'skaia udarnaia stroika). It defined such attributes of the image as internationalism, militarism, man's triumph over nature, youth, the BAM as a path to communism.

The internationalist ideas were reflected in such tropes as the "all-nation project" (vsenarodnaia stroika), "project of friendship" (stroika druzhby), "The entire nation builds the BAM" (BAM stroit vsia strana), etc. At the same time, though, "the journalists rarely mentioned the nationality of featured BAMers who happened to be Russian, Ukrainian, or Belorussian, while they took great care to mention the home republic of any nonSlavic bamovtsy they profiled" (Ward 2001, 80-1).

However, a hidden tension in interethnic relations is often found in the biographical narratives of the builders:

They [the representatives of the patronage republic - N. B.] always kept apart, with the local people, kept haughty, did not communicate ... They 
had their own special supply (A. Maximova, personal communication, Severobaikal'sk, 2004).

The militarization of the BAM's image was expressed in the wide use of lexicon with military semantics in journalistic texts. Journalists represented the BAMers as a military avant-garde, called the workers "fighters" (boitsy), and their production achievements - "conquests" (zavoevaniia). The expression "shock construction" (udarnaia stroika) was in common usage. Each stage of construction was dedicated to the anniversaries of the October Revolution (and the Civil War), or the Great Patriotic War. The organization of the workforce used a system of Komsomol detachments with a ramified titulature (commanders, commissars, etc.). The comparison of the builders' achievement with feats in the Great Patriotic War was meant to romanticize the project and to attract young workers.

A model of post-Stalinist Prometheanism was adapted in the official image of the BAM. The conquest of nature by means of various technologies was viewed as a panacea for political, social and economic problems. Soviet interpretations of the Arctic myth were expressed in such notions as "the war against the environment," "the struggle with the elements," "the conquest of nature" and others, which were especially popular in the early days of Soviet industrialisation of the North (Schweitzer 2017, 65). The builders had to subdue nature, despite the high seismicity, permafrost, and a lack of population in most parts of the BAM region. Every day, the Soviet press cited examples of bringing civilization into deep taiga and exaggerated the comfort of working and living conditions. 
The main ideological task of the megaproject was to strengthen the waning faith of Soviet citizens in socialist ideals, consolidate disillusioned groups of the population and channel their social energy into a loyal direction. Therefore, great attention was paid to the mobilization of young people in the BAM, which was reflected in such slogans as "BAM is a matter for young people" (BAM - delo molody $k h)$, "we build the BAM, the BAM builds us" (my stroim BAM, BAM stroit nas), "road of courage" (doroga muzhestva), "tested by the route" (ispytanie trassoi).

The mission of the BAM was revealed in the concepts of "road to the future" (doroga v budushchee), "project of a century" (stroika veka), "path to communism" (put' $k$ kommunizmu). As one of the authors put it, "geography and climate do not have decisive importance for the BAM: the BAM begins in the heart and thoughts of a person: with excitement in the soul, with reflections on the place and path among people" (Belousov 1981, 5).

The great project needed its great heroic history. In the conditions of the "absence" of a pre-BAM past ("the area of pioneering development"), the Soviet press tried to find a background for the project in the notes of pre-revolutionary travelers and political exiles or in the history of the Trans-Siberian Railway. Another common storyline used to construct a new historical narrative was the geological exploration of the region, conducted in the 1930s and 1940s. Episodes associated with the history of the indigenous people (mostly Evenks) did not attract attention, because of the mismatch with the official discourse 
that portrayed the construction of the BAM as colonization of new territories.

The BAM was often placed on a par with other Soviet giants, such as Turksib, Belomorkanal, Dneproges, Komsomolsk-onAmur, or the development of virgin lands. At the same time, the history of Bamlag, relevant for such analogies, was never acknowledged.

The main hero of the BAM was a builder, especially a male one. He was a strong, open, unselfish person, who could overwinter in an army tent and endure in any living conditions. He was not interested in money and never left the door of his house locked. The images of the pioneer builder and the shock worker (udarnik) were often compared to the textbook heroes-revolutionaries. As one of the commentators proclaimed,

yes, there are still heroes like Pavka Korchagin, ${ }^{3}$ and this fills my heart with joy and pride in my generation. You know, I always envied those who fought, those who built Komsomolsk-on-Amur. I bowed before them but I will also bow to those who will bear on their shoulders the BAM (Balkov 1978, 183).

According to American BAM researcher Christopher Ward, the officially published biographies of the BAMers followed the framework of the hagiographic genre (Ward 2002). A typical scenario contained the following storyline. A young man, being in search of life purpose, gets away from the routine of everyday life to join the builders of the BAM. There, after experiencing

\footnotetext{
${ }^{3}$ Pavel (Pavka) Korchagin, the main character of Nikolai Ostrovskii's novel How the Steel Was Tempered, was an ideal to follow for several generations of Soviet people. The builders of the BAM town Taksimo started an initiative to rename it Korchagin but the Soviet government did not allow giving names to settlements in honor of fictional characters.
} 


\section{Nikolai Baikalov}

the harsh taiga climate and life in a collective, he finds genuine values that coincide with the best Soviet ideals. Now the new BAMer calls on others to follow his example.

Along with the official discourse about the BAM, there were also semi-official and unofficial ones, represented in local press, memoirs, and personal correspondence. Such sources agreed in general with the assessment of the BAM as a regular stage in the development of the productive forces of Siberia and the Soviet Far East; however, they usually put an emphasis on the personal dimension. In the 1970s and early 1980s, the Komsomol ideals increasingly came into conflict with the growing bureaucratization and stagnation of Soviet reality. For many Soviet citizens, the BAM became a symbol of true life. Young people rushed to build the mainline not only for the sake of implementing the state's proclaimed goals but also in the hope of finding the true meaning of life, to overcome its duality, to test Soviet ideals that seemed like abstract ideological slogans. As one of the authors put it,

the road ... was often like a fairy-tale mirror that reflected and restored the true values in the original undistorted form ... Someone may object: why go so far just to understand well-known things? I answer: it was worth it! Because these things need not only to be understood but also to be felt with one's heart (Rotenfel'd 1983, 138-9).

The opportunity to feel relevant in pursuit of a concrete goal and to cope with the difficulties of life in taiga led to the acceptance of collectivist values. In the minds of most builders, ideals that were previously alien and imposed from above came to resonate with personal experience. The necessity of 
building a new life in a new place brought people very close together. Subsequently, it was the totality of these experiences that conditioned the BAMers' resistance to the reassessment of the BAM by journalists in the 1990s.

It is interesting to turn to the perception of the BAM among residents of neighboring regions. For them, the first association is connected with the privileged access enjoyed by the builders to scarce food products and manufactured goods. On "Big Earth," "the BAMers were seen as rich people who dressed in imported clothes and were accustomed to spending big money. Today, in most biographical narratives, former builders emphasize their ignorance of the privileged supply. At the same time, however, they enthusiastically remember how they managed to earn enough to get two or three cars.

However, in general, the unofficial image of the BAM did not contradict the official one but rather continued and developed it. The romantic idealist turned into a wealthy romantic and enjoyed the smell of taiga from the window of his own Zhiguli automobile. Both images converged at the highest point - the belief in a bright future and the BAM as the road leading to it. It is no coincidence that many former builders still remember the BAM as a separate republic where the communist experiment was a success, where they each worked hard and received accordingly, where fair distribution was combined with general availability of most benefits and goods.

\footnotetext{
${ }^{4}$ Big Earth (Bol'shaia Zemlia) - expression used by the BAMers to designate the world outside the BAM region, close in meaning to the word "Mainland."
} 


\section{BAMERS AND NON-BAMERS}

If from the outside, the BAMers' identity was perceived as integral, consolidating the whole population of the Baikal-Amur Mainline region, inside it involved a complicated hierarchy. First of all, two groups of residents within the BAM region should be separated from the BAMers - old residents and geologists. Both emphatically avoid any associations with the "project of the century."

Old residents is the conventional designation for people who had lived in these areas since before BAM and did not directly participate in the construction. They did not receive the BAM's privileges. What is more, the building of railway violated their traditional way of life. The old residents considered the BAM and BAMers an environmental disaster, associated with pollution of nature, fires, poaching, extermination of fish, etc.:

one more year and the fish will be completely killed by the BAM... I do not know how the animals still survive, with the taiga blazed with fires from the spring until the fall ... The BAM is still being finished, when the construction ends, whoever comes to develop the economy in the BAM zone will only see scorched earth (from a personal letter of an old resident, December 27, 1986, Taximo Local Museum).

The builders of the BAM considered the natural riches of the uninhabited territories to belong to the entire nation and felt that they, as the vanguard of the working class, had the same rights to the exploitation of natural resources as the local residents. The complex and sometimes hostile relations between the preBAM locals and the BAMers resulted from these disagreements: 


\section{BAM AND BAMERS: PECULIARITIES OF IDENTITY FORMATION}

they lived here like kings. Such lands! You want meat? Just go outside and kill it. And the fish! Taimen, tugunok ... Now you cannot catch those! Of course they treated the BAMers badly (M. Kokorin, personal communication, Taximo, 2002).

Geologists, in turn, had carried out survey work for the future railway and in many ways determined its trajectory several decades ahead of the builders. However, the state denied them the right to consider themselves the first BAMers. Geologists also could not take advantage of the majority of material benefits available to the builders. In addition, they were denied the fame and public attention that the BAM builders enjoyed. As one of my interlocutors put it,

geologists are pioneers by right, who were simply pushed by the BAM

into the shadows (A. Minkevich, personal communication, Taximo, 2002).

The attitude of the BAMers to geologists differs from their attitude towards pre-BAM settlers. Nowadays, the BAMers recognize the right of geologists to the history of BAM because geologists and builders were both part of one modernizing project:

we were walking along the footpaths already traversed by them [geologists], so of course they are offended that they were the first, and they were left without attention and erased from history (M. Kokorin, personal communication, Taximo, 2002).

In the post-Soviet period, the category of non-BAMers has been supplemented by all those who came to this territory after the completion of the construction. Among others, local residents include in this group migrants from the former Soviet republics, seasonal workers of gold mining enterprises, small traders, etc. 
The actual BAMers perceive themselves as a very heterogeneous community. During the Soviet era, professional differences were relevant. The most notable occupations were tunnel builders and bridge builders. Workers employed in non-railway construction (houses, schools, hospitals, etc.) enjoyed less respect. The most unprivileged group was comprised by representatives of the service sector, facilitating the social and cultural life of the builders. The difference between these groups was, first of all, in wage size. Apart from that, some groups of builders had more comfortable settlements, better housing, and better supply of food and household goods. However, with the completion of construction and the disappearance of most building organizations, this difference was leveled.

Today, the most prosperous in material terms are the workers engaged in servicing the railway sector (MPSniki). ${ }^{5}$ However, they are not associated with the BAM. In 1996, the Ministry of Railways handed over the Baikal-Amur Railway Branch to the East-Siberian Railway, which resulted in the change of the name of the route. Local residents perceived the disappearance of the abbreviation BAM as an act of hostility:

We built the BAM! How could they [the railway authorities] throw away that name! Let's assume some economic formulas dictate the unification. But they don't respect the feelings of people who actually built the Baikal-Amur road. Now, after the BAM has become a part of the East Siberian road, we feel we have not built anything. There is no BAM now! The Baikal-Amur Mainline lives only in our hearts (S. Akimova, personal communication, Severobaikal'sk, 2004).

\footnotetext{
${ }^{5}$ From the Russian abbreviation MPS, standing for Ministerstvo putei soobshcheniia, which can be translated as Ministry of Communication Lines or Ministry of Railways.
} 
In my personal opinion, the main unofficial division that was present among of the BAM builders was between western BAMers (conventionally: visitors from the European part of Russia or the Union Republics) and local BAMers (conventionally: people from neighboring Siberian or Soviet Far Eastern regions). The "Western BAMers" or "Westerners," according to local perceptions, came to the BAM region in search of big earnings in a short time. Therefore, they treated the environment barbarically and built everything hastily, not caring about the quality of constructed objects. Following this logic, the Westerners could not have built the BAM on their own and they are not "real" BAMers or even are not BAMers at all. After the project was over, most of the Westerners left the BAM region. Those who did not manage to leave now found themselves in more difficult living conditions, because they did not prepare for permanent settlement.

The "Locals" position themselves as true BAMers, who traveled to the region not for temporary earnings but for permanent residence. They made a great contribution to the construction of the railway. However, many of them prefer not to call themselves BAMers in personal interviews, associating the word with the western newcomers. Thus, the orientation towards a temporary or permanent residence prescribes other spatial co-ordinates of identity: "temporary place of life" - Western, non-local, non-real; "permanent place of life" - Siberian, local, true.

Indeed, the Soviet statistics and opinion polls of the early 1980s confirmed a higher degree of anchoring in the new location - and, correspondingly, a smaller outflow from the 
construction zone - of newcomers from the Siberian and Far Eastern regions. The Soviet experts explained this trend by the easier adaptation of Siberians to similar natural, climatic and living conditions, as well as the proximity of the construction zone to home regions (Zhelezko 1980, 84-7).

In the narratives of Western BAMers, the romanticization of the BAM's past is stronger than in the local BAMers' ones. The majority of respondents noted that they were not informed about the high salaries and other material benefits prior to their arrival at the BAM region. Almost all interviewees from this group admit that they intended to spend a short time at the construction site but for some reason have remained until the present moment. A clear division into locals and newcomers is not observable here. Perhaps the "Westerners - Locals" dichotomy has been coined rather by representatives of the Siberian regions and is based on their values of local patriotism. They thus view the situation within the traditional framework of a conflict between newcomers and receiving communities, despite the fact that not long ago, both themselves and the Westerners were in fact outsiders. In the perception of the "Siberian" group, however, the Locals have more rights to the BAM territory because it is perceived by them as a continuation of their living space.

Another important marker of BAMers' differentiation is the time of arrival. Provisionally, three groups can be distinguished in biographical narratives. The "Old BAMers" (pioneers, first builders) were at the BAM from the first days, experienced tent life and saw a pristine taiga. They often act as heroes of the BAM's myths and legends, and true carriers of the associated 
identity. "New BAMers" - the builders who arrived at the height of construction - as a rule were engaged in the construction of permanent settlements for builders and railway workers. The third group is comprised by those who came to the Baikal-Amur Mainline after the "laying of the gold link" (connection of the western and eastern branches of the road in 1984). Thus, the later a person arrived at the BAM, the fewer rights to identify with it the person had. A whole range of tropes can be singled out as arguments for this social exclusion: they came once everything was ready; they did not know the romance of the taiga, the tent life; they did not join the collective / do not appreciate the collective, etc. As with the division of the BAMers into locals and non-locals, legitimization in terms of this second marker of BAM identity is associated with the length of stay at the BAM, determined by the time of arrival.

The same temporary criterion can be seen in generational divisions. At present, residents speak about three generations: the actual BAMers ("BAM veterans"); "BAM children," born and socialized in the midst of construction, who therefore absorbed the "BAM spirit"; and "grandchildren of BAM," who grew up during the decay of the Soviet BAM and the crises that followed the dissolution of the USSR. The latter generation is now mostly oriented towards leaving the region.

\section{BAMERS AFTER BAM}

The BAM crosses poorly developed and sparsely populated northern territories of six regions of the modern Russian 
Federation (Irkutsk Oblast, Republic of Buryatia, Trans-Baikal Region, Republic of Sakha, Amur Oblast, Khabarovsk Region). The collapse of the Soviet state and the curtailment of socioeconomic development programs for these territories led to a protracted depressive situation. The constructed railway appeared to be unprofitable in the new market conditions, while both temporary and permanent settlements along the mainline didn't have any other city-forming enterprises. In the late $80 \mathrm{~s}$ and early 90s, the BAM was viewed as a typical Soviet longterm construction, an economically unjustified project, brought to life by the military and political rivalry with China rather than by the socio-economic needs of developing the northern 246 regions of Siberia and the Russian Far East. In the press, you could find articles with headings like "BAM - the road to nowhere," "BAM - a monument to stagnation" (Grushevskii 1988, 4; Khatuntsev 1987, 3).

Despite the somewhat skeptical attitude of the BAMers towards the official Soviet discourse, attempts to reinterpret the history of the BAM in a new way were perceived by the population in a hostile manner. Fearing they would be erased from history, the BAM veterans published protest articles in the press and in jubilee collections of biographies of BAM workers (often containing reprints of Soviet texts). In comparison with the life in the 1990s, the main period of construction of the mainline began to be idealized in the mass consciousness of local communities, turning into a myth about the "golden age." Many informants, regardless of the place of their present residence, remember with warmth their life on the Soviet BAM, 
referring to it as the happiest time of their lives (Bogdanova 2013). As one of my interlocutors said,

The BAM was not an ordinary construction project, it was a special style of life, when everyone would not wait to be called to help, but immediately came to help you. It was a place where a person was appreciated not for some material things but for his or her personal value. Today it is not. But everyone should find his or her own BAM in this life (T. Vetrova, personal communication, Severobaikal'sk, 2018).

The personal commemoration of the BAM is highly interconnected with the collective memory of the heroic history. "Many BAMers remember the Soviet past in a positive way; all the difficulties, bad habits and problematic relationships are not to be remembered. Such way of commemoration helps people not to lose their own identity and compensates for today's difficult situation" (Rior [Röhr], 2016).

In the 1990s, veterans of the BAM organized a public organization - the Union of Pioneers of BAM, the main purpose of which was allocating areas along the railway into a separate administrative unit - the BAM Republic:

We collected two hundred pioneers. And then we put forward the idea of making the BAM a separate republic. We prepared an appeal to the government of Russia. Well, the heads seemed to talk about us. But finally the whole thing died out: they did not allow it, they only laughed (A. Chaplygin, personal communication, Severobaikal'sk, 2018).

The next initiative of the Union was the establishment of a state holiday - BAM builder's day. Activists prepared appeals to the State Duma and Legislative Assembly of the Republic of Buryatia. The date chosen was July 8 - the day when in 1974 the Soviet government issued a decree on the beginning of 
the BAM construction. The authorities of Buryatia supported the initiative and in 2018 established a new holiday at the republican level. The federal government did not give a definitive answer.

Most of contemporary behavioral strategies of local residents, including protest movements, victimization, absenteeism, etc., are based on the BAM myth. BAM identity became a ground for the consolidation of local communities. Surviving in conditions of isolation and abandonment, people began to appeal to the survival experience of first builders: the former collectivism has transformed into resource for maintaining existing social connections.

Nevertheless, there is a blurring of old and new identifications today. First of all, one can trace a non-industrial, recreational vector, aimed at identification with the natural landscape. In this sense, an interesting development is the turn of the inhabitants of the BAM region toward Baikal. During the Soviet period, the Baikal theme was not prominent in the BAM region. It was not customary to talk about the ecological problems of the lake, or to use the word "Baikal" in the macro- and microtoponymy of the BAM settlements. Despite sharing a semantic field (the Baikal-Amur Mainline), the BAM as a modernization project and Baikal as the main object and symbol of nature protection activity in the region contradicted each other. In the post-Soviet period, when the BAM's transformational pathos faded away, the competition between the BAM and Baikal did not end. The Mainline, as a symbol of the past (evoking the "construction of the century," prosperity, the "golden age"), is opposed to Baikal as a symbol of the present (the time of unresolved problems, the crisis of mono-profile settlements, the need for tourism 
development in the extremely unfavorable conditions of the northern territories). At the same time, the Baikal theme in the BAM identity has become increasingly tangible in recent decades.

The BAM did not manage to form a unified region, neither in economic nor in sociocultural terms. The limits of its perception were set not by the economic and geographical space of the permafrost regions but by the epic image of the project of a century. With the completion of the construction of the railway, the disappearance of the USSR and Soviet ideology, the BAM identity had to exhaust itself. However, due to the remoteness from the developed industrial centers and the prolonged depressive situation in the BAM region, ideas about the BAM community have been conserved. Rethinking the category of BAMers occurs at a slow pace and is connected, first of all, with the current generational change.

\section{CONCLUSION}

The Baikal-Amur Mainline became the largest modernization project of late socialism. During its construction in the 1970s and 1980s, a multi-cultural, multi-ethnic team of builders was formed that comprised migrants from all regions of the USSR. The Soviet state paid much attention to the BAM and attracted people to the northern territories with high wages, special benefits, and various moral incentives. The "project of the century" served as a festive facade of developed socialism and, according to many researchers, had to become an alternative to the stagnation of the command and administrative system. 
Having developed in such circumstances, the BAM identity absorbed both the official Soviet mythology, based on the ideological concept of an "All-Union Komsomol PaceSetting Project," and its unofficial interpretation. The main features of the BAM's image were internationalism, militarism, Prometheanism, and the idea that it embodied "the path to communism." By relating themselves to the BAM and BAMers, Soviet citizens tried to overcome the duality and formalism of the Soviet system, to vindicate the communist utopia and escape from imposed patterns of life and behavior. This circumstance led to the rapid development of a local identity into a regional, and then into a cultural one.

At the same time, the BAM identity was distinguished by a complex heterogeneous hierarchy of sub-identities. On a professional basis, it divided the BAMers into elite and non-elite groups of builders. For this study, the territorial and temporal aspects of this process are most important. Although the geography of BAM migration covered almost all Soviet republics, regions and districts, in the process of identifying the builders, the key role was played by the division into Local (Siberian) and Western BAMers. Such "locality" was perceived as a way of legitimizing one's stay at the BAM and was often determined not by geographic coordinates, but by the length of being in the region of construction. Another important differentiation marker was the time of arrival at the BAM, according to which "Old" and "New BAMers," as well as those who arrived in the region after the completion of the main building works, were classified in the respondents' narratives. 
The completion of the BAM construction, which coincided with the collapse of the Soviet state and the ensuing systemic crisis, led to the transformation of the BAM's highly developed settlements into areas of depression. The Soviet projects of locating industrial enterprises along the railway was discontinued and the railway proved to be unprofitable. Contrasted with the painful present, the Soviet past of the BAM became a myth of the "golden age," which - in turn - created the foundation for preserving the former BAM identity. Acting as a basis for the consolidation of local communities, the category of "BAMers" is transforming very slowly, mainly as a result of the departure of former builders from the region or the natural generational change.

\section{WORKS CITED}

Anisimova, Alla A., and Ol'ga G. Echevskaia. 2012. Sibirskaya identichnost': Predposylki formirovaniia, konteksty aktualizatsii [Siberian identity: Premises of formation, contexts of actualization]. Novosibirsk: Novosibirskii gosudarstvennyi universitet. Anisimova, Alla A., and Ol'ga G. Echevskaia. 2016. "Issledovanie mekhanizmov formirovaniia i transformatsii sibirskoi regional'noi identichnosti na osnove analiza biograficheskikh narrativov" [Researching mechanisms of formation and transformation of Siberian regional identity based on the analysis of biographical narratives]. In Sibir': Konteksty nastoiashchego: Sbornik materialov mezhdunarodnykh konferentsii molodykh issledovatelei Sibiri, edited by I. P. Basalaeva and M. Ia. Rozhanskii, 9-26. Irkutsk: Tsentr nezavisimykh sotsial'nykh issledovanii.

Argudiaeva, Yuliia V. 1988. Trud i byt molodezhi BAMa: Nastoiashchee i budushchee [Work and life of the BAM Youth: Present and future]. Moskva: Mysl'

Balkov, Kim N., ed. 1978. Ispytanie trassoi [Tested by the route]. Ulan-Ude: Buriatskoe knizhnoe izdatel'stvo.

Belousov, Mikhail V. 1981. BAM, do vostrebovaniia... [BAM, the general delivery railway]. Leningrad: Lenizdat.

Bogdanova, Elena A. 2013. 'Kak utopiia stala real'nost'iu: Stroitel'stvo BAMa - samoe shchastlivoe vremia v moei zhizni" [How history became reality: Constructing the BAM was the happiest time of my life]. In Topografiia shchast'ia: Etnograficheskie karty moderna, edited by N. N. Ssorin-Chaikov. Moskva: NLO. 


\section{Nikolai Baikalov}

Gordienko, Ivan V., ed. 1999. Baikalo-Amurskaia magistral' na territorii Buriatii: Istoriia stroitel'stva, eio rol' v khoziaistvennom osvoenii regiona [The BaikalAmur Railway Mainline on the territory of Buryatia: History of its construction, its role in the region's economic development]. Ulan-Ude: Izdatel'stvo BNTs SO RAN

Grushevskii, V. 1988. "Bez fanfar: BAM: pamiatnik zastoiu ili doroga v budushchee?" [Without fanfare: BAM: A monument to stagnation or a road to the future?]. Pravda newspaper, December 28: 4.

Grützmacher, Johannes. 2012. Die Baikal-Amur-Magistrale: Vom stalinistischen Lager zum Mobilisierungsprojekt unter Brežnev [The Baikal-Amur Railway Mainline: From a Stalinist camp to a mobilization project under Brezhnev]. München: R. Oldenbourg Verlag.

Khatuntsev, V. 1987. "Bum i BAM: Pochemu molodaia magistral' ne rabotaet v polnuiu silu" [Boom and BAM: Why the new mainline doesn't operate at full capacity]. Pravda newspaper, June 11: 3 .

Kin, Alexander A. 2016. "BAM i prilegaiushchie territorii: Uroki i perspektivy osvoeniia" [BAM and surrounding areas: Results and prospects of development]. Vestnik Sibir'skogo universiteta potrebitel'skoi kooperatsii 1 (16): 57-66.

Povorozniuk, Ol'ga A. 2016. "Gorodskie aborigeny BAMa: Industrial'nyi bum, tekhnosotsial'nye seti i bor'ba za resursy" [Urban aborigines of the BAM: Industrial boom, techno-social networks and fight for resources]. Etnograficheskoe obozrenie 1: $23-40$.

Povorozniuk, Olga A. 2017. "Social Dynamics and Sustainability of BAM Communities: Migration, Competition for Resources, and Intergroup Relations." In New Mobilities and Social Changes in Russia's Arctic Regions, edited by M. Laruelle, 133-57. London: Routledge.

Rior [Röhr], Andreas. 2016. "Poselok Niia (Gruzinskaia) v gody Gruzstroibama (1975-1982): Kommemoratsiia i vospominaniia byvshikh rabotnikov i nyneishnikh zhitelei" [The Settlement Niia (Gruzinskaia) in the years of Gruzstroibam (19751982): Commemoration and memories of former workers and current residents]. In Sibir': Konteksty nastoiashchego: Sbornik materialov mezhdunarodnykh konferentsii molodykh issledovatelei Sibiri, edited by I. P. Basalaeva and M. Ia. Rozhanskii, 225-40. Irkutsk: Tsentr nezavisimykh sotsial'nykh issledovanii.

Rotenfel'd, Boris S. 1983. Zemlia dobroi nadezhdy [Land of good hope]. Irkutsk: Vostochno-Sibirskoe knizhnoe izdatel'stvo.

Rozhanskii, Mikhail Ia., ed. 2012. Gorod posle kombinata: Sotsial'no-ekonomicheskie strategii zhitelei goroda Baikal'ska [The city after the plant: Socio-economic strategies of the inhabitants of Baikal'sk]. Irkutsk: Tsentr nezavisimykh sotsial'nykh issledovanii i obrazovaniia.

Schweitzer Peter, Olga Povoroznyuk and Sirgid Schiesser. 2017. "Beyond Wilderness: Towards an Anthropology of Infrastructure and the Built Environment in the Russian North." The Polar Journal 7 (1): 58-85.

Shinkarev, Leonid I. 1975. Baikalo-amurskaia magistral' [The Baikal-Amur Railway Mainline]. Moskva: Sovetskaia Rossiia. 
Ward, Christopher J. 2001. "Selling the 'Project of the Century': Perceptions of the Baikal-Amur Mainline Railway (BAM) in the Soviet Press, 1974-1984." Canadian Slavonic Papers/Revue canadienne des slavistes 43 (1): 75-95.

Ward, Christopher J. 2002. The "Path To The Future" or the Road to Nowhere? A Political and Social Examination of the Construction of the Baikal-Amur Mainline Railway (BAM), 1974-1984. PhD diss., University of North Carolina, Chapel Hill.

Zhelezko, Sergei N. 1980. "Faktory stabilizatsii kadrov na stroitel'stve BAM" [Factors of workforce stabilization during the BAM construction]. Sotsiologicheskie issledovaniia 1: 84-7. 


\section{Daria Burnasheva}

ORCID 0000-0002-2029-6115

Arctic State Institute of Culture and Arts

\section{SEARCHING FOR A NEW IDENTITY \\ IN A NEW ERA: EMERGENCE AND DEVELOPMENT OF SAKHA \\ (YAKUTIA) AS AN ARCTIC REGION*}

\section{ABSTRACT}

The Arctic identity is most widely studied in relation with Indigeneity, which is often seen as being threatened by globalization processes. In this paper, the Arctic identity of Sakha (Yakutia) is explored from the regionbuilding perspective, using a constructivist approach to reveal the principal factors that have shaped it. In this regard, my interest is the role of actors of Arctic identity. I argue that the development of Arctic identity has been largely influenced by, though not limited to, the globalization process.

Keywords: region, region-building, regional identity, Arctic, globalization

* Parts of this paper are excerpts from an unpublished $\mathrm{PhD}$ dissertation defended in 2019 at the University of Warsaw. I made similar points derived from the dissertation in another paper, forthcoming in Anthropology and Archeology of Eurasia. The references are included where necessary. 


\section{INTRODUCTION}

Russia's vast and diverse regions present an interesting case in the study of regions and regional identity. Among them, the experiences of the northern regions presents a special interest in the light of current Russian Arctic policy. The Republic of Sakha (Yakutia) is one of Russia's northernmost regions and, not insignificantly, its largest federal subject. This vast area of about 3 million square kilometers is sparsely inhabited by less than a million residents, almost one-third of them residing in the urban area of the capital Yakutsk. In general, the local demographic trends reflect the greater tendencies in the Arctic region, including the growing urbanization and specific migration patterns (Heleniak 2014).

On April 4, 1992, the Republic of Sakha (Yakutia) legislated its Constitution. Notably, this happened well before the Russian Federation ratified its own (Balzer and Vinokurova 1996). Moreover, maintaining its strong regional identity, Sakha (Yakutia) was also among the first in the Russian Federation to declare itself an Arctic region. However, the Arctic has not been the only option for Sakha (Yakutia). There were alternative identities, and the representations of Arctic identity did change over time from active manifestation to fading away, to a comeback to political agenda. Today, the Arctic is probably the most actively manifested aspect of the republic's regional identity (Burnasheva 2020). 
This paper examines, paying attention to the influence of globalization, how the Arctic region-building project in Sakha (Yakutia) has been constructed from specific spatial and cultural traits. It explores a number of questions, such as: How and why did the idea of the Arctic emerge in the region, and which identities existed along with a northern spatial identity? Which factors have shaped the Arctic identity of Sakha (Yakutia)? Which actors have been involved in the construction of it as an Arctic region? Which symbols were used to create an Arctic region from the new political entity? In order to examine these questions, we must first explore the relations between region and identity, and between identity and globalization.

\section{THEORETICAL CONSIDERATIONS}

Regionalization is one of the most current and dynamic processes in contemporary world. Not only do new regions emerge in the states throughout the world, but new transnational, cross-border formations are also created. One such great transnational region is the Arctic region, connecting eight different states. Other regions of this kind in the North include the quite successful Nordic region, the Baltic Sea region and the recently re-emergent and much discussed Barents region. Interestingly, the main writings on region, region-building and regional identity are produced by Nordic authors (Keskitalo 2004), including the Finnish geographer Anssi Paasi, whose ideas on the concept of region and regional identity have shaped the methodology of this paper. 
A constructivist, region-building approach will be used as the theoretical framework. This approach investigates specifically the constitution process of a region; however, one should not think of the construction of a region as a mere political choice. Though constructed, regions are always historically and culturally rooted, they are not created ex nihilo. The region-building approach investigates not only how regions are constructed, but also why they emerge. The region is thus a choice made on specific historical and political grounds, and a result of intentional actions of certain actors (Neumann 1992; 1999; Paasi 1986).

It is necessary to bear in mind that the region is not a static phenomenon. Once created, it is never complete. It is a dynamic, historically continuous process, which brings together other processes - political, historical and cultural. The process during which the region becomes an established entity, reproduced in individual and institutional practices, is the institutionalization of the region. It is associated with the assumption of territorial shape, the formation of conceptual (symbolic) as well as institutional shape, and the establishment as an entity in the regional system and in the local social consciousness, or the establishment of regional identity. Regional identity is therefore a result of the institutionalization process. Moreover, one should distinguish the identity of inhabitants and identity of the region (Paasi 1986). In our analysis, we shall concentrate on the latter.

The constructivist approach to region and identity is closely connected with the concept of globalization. Though relations 
between the Arctic and globalization have often been seen as a problem in view the negative impact of extractive industries and climate change, the true nature of the Arctic region is that it is an answer to globalization (Keskitalo 2004), since the Arctic regional identity is an outcome of institutional and intergovernmental co-operation (cf. Schweitzer, Sköld and Ulturgasheva 2014). Therefore, in the framework of this paper, the Arctic identity in its regional aspect is seen as a product of globalization. In fact, the identity and globalization are in a permanent interaction, and one determines the growth and development of the other (Castells 2010; Tomlinson 2003).

Such framework offers an opportunity to analyze the case of Sakha (Yakutia) and examine the process of the Arctic identity development on a regional level. The construction of the Arctic identity of Sakha (Yakutia) has been based on particular historical and political grounds and has been the result of collective efforts of particular actors. Moreover, in this Arctic region, the identity has been constructed by and for particular actors and interests (Keskitalo 2007). I claim that the rise of an Arctic identity in Sakha (Yakutia) in the post-Soviet period has also been influenced by, though not limited to, the emerging and intensively developing international cooperation in the Arctic.

\section{HOW AND WHY DID THE IDEA OF THE ARCTIC EMERGE IN SAKHA?}

The Arctic identity of Sakha was, first, culturally and historically grounded, second, influenced by a growing significance 
of the Arctic in global affairs (Burnasheva 2020). The historical Murmansk speech of the then Soviet Premier Mikhail Gorbachev, which focused on disarmament and environmental issues, is claimed by experts to be the main inspiration for future Arctic relations (Nilsson 2009; Steinberg, Tasch and Gerhardt 2015).

As Koivurova (2010) notes, the Arctic was not perceived as a place for intergovernmental cooperation before Gorbachev's speech. Previously, reality in the Arctic was dominated by fears of the possibility of it becoming a hot spot of the cold war, so this much inspiring speech has become a sort of a symbol of the "melting" Arctic, both literally and figuratively. Gorbachev's 260 speech spurred the establishment of the first ever circumpolar cooperation project, the Arctic Environmental Protection Strategy (1991), which later gave rise to the Arctic Council (1996), the main organization in the Arctic region.

The understanding of and support for the Arctic issues by the national political elite further motivated and advanced the development of the Arctic identity of Sakha, derived from its spatial identity and the existing concept of the North. This concept is deeply rooted in Sakha consciousness: in the Sakha language, khotu, "north," is also used in common expressions such as innin khotu - "forward," sireiin khotu - "straight forward," baghatyn khotu - "according to one's wish." Soghuruu, "south," refers to all places other than the republic. Here, the actual geography does not matter, since the term denotes otherness (Burnasheva 2020). As various ancestors of the Sakha migrated to the north over the course of several centuries (Vasil'ev 
1995), Sakha culture was shaped by the north, and the Sakha have formed as a nation in the north, it can be suggested that the mental map of the Sakha is north-oriented.

The conceptualization of Sakha as an Arctic region developed at a time of very complicated political circumstances. The years after the dissolution of the Soviet system were challenging. The regional political elite often faced incomprehension, especially from the federal center, and sometimes even clear unwillingness to accept the forming federalist tendencies (Nikolaev 1996). The reasons for Sakha desire to have their own political unit within Russia were twofold. First, the Sakha had in their favor the fact of being the demographic majority in their land and of its cultural homogeneity. Second, they desired to control their own social and economic agendas, considering the region's immense natural resources, like gold and diamonds, to name just a few. Despite all the challenges, on September 27, 1990, the Declaration of State Sovereignty was adopted. It declared the republic a sovereign unit within the Russian Federation. In December 1991, the republic elected its first ever president, Mikhail Nikolaev, who was a key figure in the establishment of sovereignty as well as the emergence and development of the Arctic identity of Sakha. Two years later, the Constitution of the Republic of Sakha was signed on April 4, 1992. At that time, a new Russian term iakutianin (Yakutian) was introduced to the official discourse as a distinct term for the sub-national identity of people living in Yakutia. The processes of Arctic region-building and Sakha nation-building went hand in hand - they were in fact two sides of the same coin. 
The newly gained sovereignty allowed for self-government in important spheres, including regional politics and international relations. In the case of Sakha, the idea of the Arctic was supported by the theory of circumpolar civilization, introduced by President Mikhail Nikolaev in numerous publications, declarations and activities. Promoting this concept drew on the support of local scholars, who developed the notion of "circumpolar civilization" on the basis of Arnold Toynbee's arrested civilizations (Stammler-Gossmann 2007), which have formed in response to physical challenges presented by the tyranny of Arctic nature, too great to overcome, and which therefore "have kept alive, but failed to grow" (Toynbee 1987, 164). Though recent knowledge discredited some of his ideas, such as Eskimo civilisation being a development of Indian way of life, it was useful for defining the special role of the environment in the cultures and worldviews of Indigenous peoples of the Arctic.

In this connection, the sociologist Uliana Vinokurova (2011) defines circumpolar civilization as a community of people living in similar climatic/natural conditions of the circumpolar North and being united by similarities in culture, both spiritual and material, and worldview. The notion provided a good opportunity to underline the uniqueness and the advantages of the northern community (Stammler-Gossmann 2007). It was also a demonstration of the willingness of Sakha to become an independent player in the international arena.

The Arctic identity of Sakha (Yakutia) was a result of an evolution of the concept of the North and related notions. It was 
a declaration that Sakha (Yakutia) is one of the northernmost regions in the world and a member of international Arctic community. All these ideas were formulated by the regional elites, academics and politicians, striving to find solutions for the region in a new era (Burnasheva 2020).

\section{AN ALTERNATIVE IDENTITY}

Researchers conclude that the Sakha formed as a nation in the middle basin of the Lena River, as a mixture of Turkic-Mongolian and Tungus-Manchurian tribes with local Paleoasiatic tribes, most probably Ugro-Samoyedic (Vasil'ev 1995). Both Sakha self-definitions and Russian historical and ethnographic accounts situate the Sakha sometimes with reference to an Asian past, sometimes as inheritors of the European Russian (especially Soviet) legacy, and increasingly as an emerging arctic state in the "Russian Far North" (Cruickshank and Argounova 2000). The latter definition was chosen for building the regional identity.

An Arctic identity therefore was not the only option for Sakha. One of the alternative identities was rooted in the Asian past and based on the archaic origin myths of the Sakha, described in the Olonkho epic. The epic is the only historical record prior to Russian documents. Its complicated plots can be tens of thousands verses long, unfolding the grandiose account of Sakha struggles to stabilize human life in the middle world. The epic begins in the Asian steppes and dramatizes achievements of the pastoralist ancestors who traveled north to the Lena River (Cruickshank and Argounova 2000). 
The Olonkho plots, along with the Turkic origins of the Sakha language and presence of lexis denoting southern flora and fauna, stimulated the growth of theories about the southern origins of the Sakha and their common history with other Asian nations. The popularity of this idea in the 1990s and desire of some of the intelligentsia to choose this identity over others reflected a need for identification and restoration of a sense of belonging, which unsurprisingly became highly relevant considering the weakened state ideology and the political circumstances of that period (Burnasheva 2020). However, though historically rooted, this idea was not really successful.

In the early 1990s, as Stammler-Gossmann (2007) notes, many regional leaders across Russia suggested their own ideas for regional identities, often engaging the existing international relations, which became an important support for the regions in their search. International relations were developed mainly along ethnic or confessional lines, for example the Finno-Ugric cooperation (Saarinen 2001), or the "Euro-Islam" movement (Khakim 1998). Yet the language factor was not strong enough for identification. Since the idea of the Pan-Turkic world was based mainly on common religion, it was not relevant for Sakha (Yakutia), where Indigenous peoples have kept their traditional beliefs, though influenced by traditions of Orthodox Christianity (Burnasheva 2020). 


\section{BUILDING AN ARCTIC SAKHA (YAKUTIA)}

The development of Sakha (Yakutia) as an Arctic region occurred in distinct phases. The first phase, during which the idea was introduced and developed, lasted from the early 1990s to around 2000. The process of building an Arctic region out of Sakha during this period was in keeping with Paasi's model of regional institutionalization (Paasi 1986). President Nikolaev along with Yakut scholars were the main actors of Arctic region-building in Sakha (Yakutia). It was done through numerous publications in the mass media and Nikolaev's books. It was also strongly linked to institution-building and involved a use of symbols and symbolic actions. At that time, research

and publishing on the Arctic flourished. Research institutes and universities made their contribution through the work of scholars and scientists who could both confirm and promote their own regional identity. A special State Committee on the Arctic Issues was established to deal with matters of the region. President Nikolaev was convinced that the North should be treated with great care, with focus on human well-being and social welfare, and he and his team tried to achieve these goals.

\section{ASSUMPTION OF REGIONAL AWARENESS}

The assumption of regional awareness is the first stage in the process of institutionalization (Paasi 1986, 124). For Sakha (Yakutia), this was associated with a symbolic re-acquisition of the native lands, which was expressed in numerous activities 
for their protection. As Bychkova-Jordan (2002) notes, in 1995, Sakha, along with other Siberian regions, made a top story in the September issue of the Time Magazine, which described the environmental damage brought by Soviet exploitation and acknowledged the republics' efforts to deal with this heavy legacy (Linden 1995). Indeed, this stage was characterized by the environmental concerns being put in the center of attention: Sakha had never done as much to protect its environment as it did during that period. The Arctic natural environment was declared part of the heritage of the Yakut nation, and to protect this heritage, a number of legislative acts were adopted.

Sakha was among the first regions in Russia to develop and adopt a law on nature conservation (1991), a few months before the federal government issued a similar law. It was likewise the first in Russia and the Commonwealth of Independent States to declare its territory a nuclear-free zone (1991). Also that year, the Ministry of Environmental Protection was established. Among the activities aimed at protecting the environment was the creation of nature reserves. The active engagement of the republic in nature conservation and promotion of environmental awareness received positive reaction from the international community. The international exposure also allowed the government to negotiate above the heads of the Kremlin bureaucrats. Whatever the motives were, as long as it helped to preserve the fragile Arctic ecosystems, the ends seemed to justify the means (Bychkova-Jordan 2002, 257).

In 1995, WWF Sweden co-funded the republic's initiative to construct an international biological station in the high-Arctic 
area in the delta of the Lena River. The Nordenskiold Station, celebrating the Arctic exploration and the famous Vega expedition along the Northeast Passage led by Finnish-Swedish explorer Adolf Erik Nordenskiold, was opened by the WWF Chairman Prince Philip, the Duke of Edinburgh, and Sakha President Mikhail Nikolaev. This event can be regarded as a symbol of international acknowledgement of the republic's work to protect the Arctic environment. All in all, the numerous actions of the government of Sakha - legal regulation of natural resources use, creation of new nature reserves, establishment of new institutions and promotion of environmental awareness among its residents - strengthened its reputation among Arctic countries.

\section{ESTABLISHMENT OF SYMBOLIC SHAPE}

During the conceptual formation of a region, certain regional symbols become established (Paasi 1986). The formation of symbols is based largely on regional, cultural and physical elements of distinctiveness (Legaré 2002). In the case of Sakha, the Arctic identity was largely manifested through the Arctic climate and environment. The concept of the Arctic is closely related to the concept of coldness (Vinokurova 2011), which was successfully employed to promote the Arctic image of Sakha, both nationally and internationally. Sakha is the coldest permanently inhabited place on the northern hemisphere, with three geographical locations where the lowest temperatures were recorded: Verkhoyansk has had the absolute minimum $\left(-67.8^{\circ} \mathrm{C}\right)$, Delyankir has the lowest annual average temperature, and 
Oymyakon has the lowest average temperature in January (Ivanova 2006, 17). With the opening of borders to foreign tourists and development of local tourism companies, Oymyakon started to draw international attention. This gradually led to the organization of an international festival, which gathered travelers and explorers from all over the world interested in northern cultures and unique natural environment. Santa Claus from Lapland and Russian Ded Moroz were invited to participate in the festivities along with the Sakha Master of cold - Chyskhaan, a character created by local sculptor Semion Sivtsev and later reinterpreted by designer Avgustina Filippova. Both the area and the festival were branded as the "Pole of Cold," which was also used for Sakha (Yakutia) in general. The concept of coldness thus played a significant role in the formation of Arctic identity. Another such symbol was the permafrost, regarded as a distinctively local phenomenon. Paleontological research flourished before and during this period, which led to the founding in 1991 of the specialized research institution that is the Mammoth Museum. Since its establishment, it has made numerous discoveries of global significance. The Mammoth Museum has a large collection of typical representatives of the mammoth-era fauna, such as the woolly rhinoceros, wild horse, muskox, bison, cave lion, etc. The mammoth itself became a brand of the region. Some examples of its usage include the mammoth logo of Yakutsk University, an international circus festival, a popular restaurant, etc.

The fall of the Iron Curtain and development of international relations engaged Sakha (Yakutia) in active dialogue with 
other countries of the globe. Throughout the world, the town twinning concept became increasingly popular, and the republic also joined this movement, with Yakutsk establishing partnership with the Alaskan city of Fairbanks in 1991. The partnership aims to promote cultural, intellectual, and economic exchange between two northern cities which are both geographically removed from national centres, having many similarities in their economies, demography, history, and the lifestyles of their citizens (Fairbanks North Star Borough 1991). The cooperation led to the signing of an agreement between the University of Alaska Fairbanks and Yakutsk University in 1991, which provided the first international agreement and partner for the latter. The agreement was fruitful: already in 1993, the two sides launched a joint educational tourism program, which was the first of its kind in Russia, and started the academic exchanges of students and staff.

Hence, during that period, Sakha (Yakutia) actively positioned itself as an Arctic player, able to communicate and develop its own foreign policy independently from the federal government. It also became a member of the international non-profit organization Northern Forum in 1993, joining the actively forming international community along with other northern and Arctic regions.

\section{DEVELOPMENT OF INSTITUTIONS}

The second and third stages of region-building are in reality simultaneous aspects of the same process, as the emergence of institutions is naturally linked with the increasing employment 


\section{Daria Burnasheva}

of the name and other territorial symbols and signs of the region (Paasi 1986, 126). In the 1990s, President Nikolaev appealed to the experience of Canada and the US in sustainable development of the North, and a lot of activities were taken for the sake of the republic's socio-economic growth. At that time, the Parliament of the Republic of Sakha adopted a number of legislative acts that aimed at fostering the socio-economic betterment of the North. It launched so-called national programs for the support of traditional economic activities, local cultures, languages, among other issues (Nikolaev 1997).

Identity-building found expression in a range of initiatives, including the establishment of new education and research institutions. This phase was characterized by the production of knowledge about the region and its Arctic aspect, with the republic sponsoring and organizing a number of high-level international conferences. Another example is the establishment in 2001 of the Arctic Institute of Culture and Arts, the only higher education institution in Russia specializing in Arctic cultures. The mission of the institute was the preservation of traditional cultures as well as the restoration of ethnic memory, dignity and pride of Indigenous Arctic youth. The institute became the center for education of young artists and cultural workers not only from Sakha, but also from other regions of Siberia and the Russian Far East.

In 1998, Yakutsk University joined the newly established University of the Arctic, an international network of educational institutions of the North, which became the driving force for international cooperation in the educational and scientific field 
in the Arctic. One of great achievements of this cooperation was the academic mobility program, thanks to which students from Sakha had an opportunity to study at other Arctic universities. The exchanges had a great positive impact in terms of not only enriching the students' knowledge and skills but also shaping among young people a sense of belonging to a greater Arctic community. The cooperation of Yakutsk University with other universities in the Arctic resulted in dozens of joint international projects aimed ultimately at sustainable development of the North.

\section{A PERIOD OF DECLINE}

The movement towards strengthening cooperation in the Arctic region had more or less faded away between 2000 and 2007. By the end of the 1990s, the Russian foreign policy turned to the east: in 1998, it became a member of the AsiaPacific Economic Cooperation (APEC). The new perspective of foreign policy of the federal center activated the previously weaker eastern (Asian) vector of the regional policy of Sakha. To a large extent, it was influenced also by the new system of administrative division of the Russian Federation implemented in 2000. The reason behind this decision lay in the "too high number of federal subjects" and a desire to restore the effective control over the vast territory of the country. Quite surprisingly, according to the new administrative division, Sakha became one of the regions of the Far Eastern Federal District. As a result, the Siberian belonging of Sakha was overshadowed by this new perspective, first in official discourse and then in popular thought. 
This process included the establishment in 2000 of Yakutsk University's Eastern Department, which immediately had the largest number of applications from prospective students, wishing to learn the Chinese, Korean and Japanese languages. The eastern perspective of foreign policy of Sakha (Yakutia) was manifested by the organization, also in 2000, of the first "Children of Asia" International Sports Games, held subsequently every four years. Sponsored by the republic's government, it included a wide range of sports and involved hundreds of participants from many Russian regions and from abroad. It was therefore seen as a symbol of Sakha being a member of a larger Asian community (Bychkova-Jordan 2002).

However, this period of eastern dominance in foreign policy was short. In 2007, in circumstances covered extensively by the media, Russia planted a flag on the North Pole seabed during an expedition aimed at oceanographic research of the Lomonosov Ridge, triggering speculation about "a new scramble for the Pole" (Dodds and Nuttall 2015). This event gave the symbolic start to active engagement in Arctic issues of other countries. The release in 2008 of official document reflecting Russian aspirations in the Arctic $^{1}$ stimulated new regionalization processes in the country, especially in the regions lying in the northern rim from the Barents Sea to the Bering Strait.

1 "The Foundations of the Russian Federation's State Policy in the Arctic until 2020 and Beyond" were approved by Russian President Dmitrii Medvedev on September 18, 2008. The document outlines the main interests of Russia in the Arctic in four areas: the Russian part of the Arctic will serve as a strategic resource base to promote social and economic development, the Arctic shall be an area of peace and cooperation, the region's ecosystem shall be protected, and the Northern Sea Route will be introduced as a national integrated transport and communication system. 


\section{RETURN OF THE ARCTIC}

In the third phase, from 2007 to the present time, the Arctic identity re-emerged with greater force in Sakha. This phase is characterized by intensive development of the research and education sphere: the knowledge produced in previous phases has been multiplied with the growth of opportunities on both the national and international levels. Notably, the research done on Sakha (Yakutia) is now referred to as Arctic-related, and a wide usage of this association is a good indicator of the level of regional consciousness (Paasi 1986). Symbolic events in this phase have included the organization of high-level meeting of the Arctic Council Working Group for the Conservation of Arctic Flora and Fauna (CAFF) in Yakutsk (2013). The local initiatives have included the International Arctic Circus Festival, International Arctic Film Festival, the positioning of Yakutsk as the cultural capital of the Arctic and the former Yakutsk State University, now North-Eastern Federal University, as the center for Arctic research, opening of the Arctic Innovation Center at the university, and the establishment of the republic's first ever local government-imposed holidays - Day of the Arctic, Day of the Polar Explorer (poliarnik) or Day of Indigenous Peoples (Burnasheva 2020).

The most symbolic manifestation of the Arctic identity of Sakha was the initiative to declare 2014 as the Year of the Arctic in the Republic of Sakha (Yakutia). It is necessary to stress that the rise of regional consciousness was also goaded by the decision of the federal government on the Arctic Zone of Russian 
Federation, which considered as such only 5 out of 34 coastal regions. This was met with criticism by the Sakha parliament as a decision disregarding the existing experience of logistical life-support of the polar regions. It thus neglected the long established approach to the Arctic which took into consideration the natural, economic and climatic integrity of the 13 regions located above the Arctic Circle, including the river transportation system (Zhirkov 2015).

In connection with this event, the government of the republic adopted an action program for its northern regions. The plan encompassed a range of concerns but the primary aim was negotiating the issue of the Arctic Zone with the federal government in order to include in it at least the 13 polar regions of the republic. This still unresolved issue sets a new challenging goal for the government of Sakha for the coming years. ${ }^{2}$

Later in 2014, the head of the republic Egor Borisov signed the order to organize the State Committee on the Arctic, ${ }^{3}$ whose function has been to develop and implement the state policy in Arctic and northern territories of Sakha, as well as to coordinate traditional economic activities of the North. This allows us to say that the Arctic identity of Sakha is stronger than ever before, stimulated by current decidedly favorable position of the federal government towards the Arctic and at the same time its controversial decisions regarding Russia's territorial division.

\footnotetext{
${ }^{2}$ In 2019, all 13 districts situated above the Arctic Circle were eventually included in the Arctic Zone of the Russian Federation.

${ }^{3}$ In 2018, the Ministry for the Arctic and Peoples of the North was established in Sakha.
} 


\section{CONCLUSION: MAKING THE ARCTIC SAKHA}

There are several reasons why the Arctic identity was successful in the case of Sakha (Yakutia). While deeply rooted in the idea of northern belonging, the Arctic regional identity was in fact a result and product of globalizing tendencies in the late- and post-Soviet periods. To some extent, it was a response to the colonial-like, raw-materials-source status imposed by the center. The regional elites often referred to the experience of similar processes in other Arctic regions. Indeed, the regionalization processes that took place in Finnmark, Norway, in the 1970-1990s (Niemi 2007), Nunavut, Canada, in the 1990s (Legaré 2002) and Sakha were likened due to a similar special role of actors and use of means.

In a multi-ethnic and multi-confessional region that is Sakha, the spatial aspect has been a strong uniting factor. Great waves of immigration have given it a unique character. This is the case with Russian old-settlers (starozhily), who have acquired their own distinct cultural profile throughout the four centuries of presence in Sakha, and with those newcomers, Russian and otherwise, who came as a part of the Soviet "conquest of the North" and who also acquired a specific spatial identity over the decades spent in the North (Bolotova and Stammler 2010; Nuykina 2011; Shibut 2006). Throughout decades and centuries, the newcomers have been brought together by an idea of the Arctic that emphasizes the existing northern dimension and related associations, such as the cold climate, long winter, and permafrost as main identity markers. 
The actors of Arctic regionalization - academics and politicians, led by the first president Nikolaev - were modernists with a vision and understanding of global geopolitical processes, which were shaping the forthcoming "age of the Arctic" (Young 1986). They claimed that key to sustainability in the Arctic was a combination of traditional values of Indigenous peoples with modern technologies. As they believed, such approach would enable the development and modernization of the republic, benefiting from its immense natural resources (Nikolaev 1996).

My analysis does not pretend to explain the whole process of region-building in Sakha. However, it sheds some light on the regional processes in Sakha in early phases of state sovereignty and brings to our attention initiatives fostering self-identification in the context of rising global and national interest in the Arctic region. The study offers an interesting framework for interpreting the creation of regional identity in the multi-ethnic region. Region-building is a continuous undertaking, an inseparable part of the perpetual process of social reproduction within a given setting (Paasi 1986), which also means that there will always be other, alternative identities. Currently, however, there is definitely a trend toward strengthening of the Arctic identity of Sakha (Yakutia).

\section{WORKS CITED}

Balzer, Marjorie Mandelstam, and Uliana A. Vinokurova. 1996. "Nationalism, Interethnic Relations, and Federalism: The Case of Sakha Republic (Yakutia)." Europe-Asia Studies 48 (1): 101-20. 


\section{SEARCHING FOR A NEW IDENTITY IN A NEW ERA...}

Bolotova, Alla, and Florian Stammler. 2010. "How the North Became Home: Attachment to Place Among Industrial Migrants in Murmansk Region." In Migration in the Circumpolar North: Issues and Contexts, edited by L. Huskey and Ch. Southcott, 193-220. Edmonton: Canadian Circumpolar Institute Press.

Burnasheva, Daria. 2020. "Arctic Identity: Between Frontier and Homeland." Anthropology and Archeology of Eurasia (forthcoming).

Bychkova-Jordan, Bella. 2002. “A Geographical Perspective on Ethnogenesis: The Case of the Sakha Republic (Yakutia).” PhD diss., University of Texas at Austin.

Castells, Michael. 2010. "Globalisation and Identity." Quaderns de la Mediterrània 14: 254-62.

Cruikshank, Julie, and Tatiana Argounova. 2000. "Reinscribing Meaning: Memory and Indigenous Identity in Sakha Republic (Yakutia)." Arctic Anthropology 37 (1): 96-119. Accessed March 2, 2017. http://www.jstor.org/stable/40316520

Dodds, Klaus, and Mark Nuttall. 2015. The Scramble for the Poles: The Geopolitics of the Arctic and Antarctic. Cambridge: Polity Press.

Heleniak, Timothy. 2014. "Arctic Populations and Migration." In Arctic Human Development Report: Regional Processes and Global Linkages, edited by J. N. Larsen and G. Fondahl, 53-105. Copenhagen: Nordic Council of Ministers.

Ivanova, Rozaliia N. 2006. "Rekordno nizkie temperatury vozdukha v Evrazii" [The lowest air temperatures in Eurasia]. Vestnik Severo-Vostochnogo federal'nogo universiteta im. M. K. Ammosova 3 (1): 13-9.

Keskitalo, Carina E. H. 2004. Negotiating the Arctic: The Construction of an International Region. New York, London: Routledge.

Keskitalo, Carina E. H. 2007. "Development of the Arctic as an International Region." Cooperation and Conflict: Journal of the Nordic International Studies Association 42 (2): 187-205.

Khakim, Rafael'. 1998. "Russia and Tatarstan: At a Crossroads of History." Anthropology and Archeology of Eurasia 37 (1): 30-71.

Koivurova, Timo. 2010. "Limits and Possibilities of the Arctic Council in a Rapidly Changing Scene of Arctic Governance.” Polar Record 46 (237): 146-56.

Legaré, André. 2002. "Construction of a Regional Collective Identity the Canadian Arctic." Wicazo Sa Review 17 (2): 65-89.

Linden, Eugene. 1995. "The Tortured Land." Time Magazine, September 4: 45-53.

Neumann, Iver. 1992. "From a Nordic Region to What?" In The Baltic Sea Area: A Region in the Making, edited by S. Jervell, M. Kukk and P. Joenniemi, 62-73. Karlskrona: The Baltic Institute.

Neumann, Iver. 1999. Uses of the Other: The East in European Identity Formation. Manchester: Manchester University Press.

Niemi, Einar A. 2007. "North Norway: An invention?" Journal of Northern Studies 1-2: 81-94.

Nikolaev, Mikhail. 1996. Pogovorim na chistotu [Let's get this straight]. Moskva: Sakha Center. 


\section{Daria Burnasheva}

Nikolaev, Mikhail. 1997. Stanovlenie $i$ razvitie mezhdunarodnykh $i$ vneshneekonomicheskikh sviazei Iakutii [Development of international relations and foreign trade of Yakutia]. Iakutsk: Bichik.

Nilsson, Annika E. 2009. "A Changing Arctic Climate: More Than Just Weather." In Legacies and Change in Polar Sciences: Historical, Legal and Political Reflections on the International Polar Year, edited by J. Shadian and M. Tennberg, 9-34. Farnham: Ashgate Publishing.

Nuykina, Elena. 2011. Resettlement from the Russian North: An Analysis of State-Induced Relocation Policy. Rovaniemi: Arctic Centre.

Paasi, Anssi. 1986. "The Institutionalization of Regions: A Theoretical Framework for the Understanding of the Emergence of Regions and the Constitutions of Regional Identity." Fennia 164: 105-46.

Saarinen, Sirkka. 2001. "The Myth of Finno-Ugrian Community in Practice." Nationalities Papers 29 (1): 41-52.

Schweitzer, Peter, Peter Sköld and Olga Ulturgasheva. 2014. "Cultures and Identities." In Arctic Human Development Report II: Regional Processes and Global Linkages, edited by J. N. Larsen, G. Fondahl and H. Rasmussen, 105-50. Copenhagen: Nordic Council of Ministers.

Fairbanks North Star Borough. 1991. "A Resolution Formalising a Sister City Relationship Between the People of the Fairbanks North Star Borough and Yakutsk, YSSSR.” Fairbanks: Borough Clerks Office.

Shibut, Irina A. 2006. "Sotsial'naia i individual'naia identichnost' naseleniia Kol'skogo Severa v kontekste regional'noi identichnosti" [Social and individual identity of residents of Kola North in the context of regional identity]. PhD diss., The Herzen State Pedagogical University of Russia, St Petersburg.

Stammler-Gossmann, Anna. 2007. "Reshaping the North of Russia: Towards a Conception of Space." Arctic \& Antarctic: International Journal of Circumpolar Sociocultural Issues 1 (1): 53-97.

Steinberg, Philip E., Jeremy Tasch and Hannes Gerhardt. 2015. Contesting the Arctic: Politics and Imaginaries in the Circumpolar North. New York: Palgrave.

Tomlinson, John. 2003. "Globalization and Cultural Identity." In The Global Transformations Reader: An Introduction to the Globalization Debate, edited by A. G. McGrew and D. Held, 269-77. Cambridge: Blackwell Pub.

Toynbee, Arnold J. 1987. A Study of History, abridged by D.C. Somervell. Vol. 1. Oxford: Oxford University Press.

Vasil'ev, Fedor. 1995. Voennoe delo iakutov [The military affairs of Yakuts]. Yakutsk: Bichik.

Vinokurova, Uliana A. 2011. Tsirkumpoliarnaia tsivilizatsiia: Idei i proekty [The circumpolar civilization: Ideas and projects]. Yakutsk: AGIIK.

Young, Oran. 1986. "The Age of the Arctic.” Foreign Policy 61: 160-79.

Zhirkov, Aleksandr. 2015. "Arktika nuzhdaetsia v kompleksnom regulirovanii" [The Arctic needs complex regulation]. Parliament newspaper 23 (2698): 8-12. 


\title{
Galina Dondukova
}

ORCID 0000-0002-4390-7556

East-Siberia State University of Technology and Management

\section{THE NOMAD'S STAR \\ OF BAIR DUGAROV AS THE GUIDING LIGHT OF POST-SOVIET BURYATIA*}

\begin{abstract}
The Nomad's Star is undoubtedly the most prominent poem of Bair Dugarov. Having appeared in the critical time of post-Soviet searching of selfidentification among the Buryats, the poem instantly gained popularity. In this article, I argue that the poem The Nomad's Star becomes the guiding light for the modern generation of Buryats after the collapse of the Soviet Union. Dugarov calls upon his contemporaries not to forget the nomadic principles of the ancestors. He employs such motifs and artistic images which reproclaim the ideas of lineage continuation, the ancestors' cult, and harmony in the family - values that are relevant and vital at all times.

I close read the poem The Nomad's Star and outline main cultural concepts depicted in it, such as "route," "hearth," "lineage," and others, which promote the revival of ethnic consciousness in the memory of the Buryats. I support my argumentation with the words of the poet himself and literary critics' opinions. The public discourse and social network materials devoted to The Nomad's Star are also called upon, evidencing the poem's role and significance in contemporary Buryatia.

* This article is a revised version of Chapter 3 of my $\mathrm{PhD}$ dissertation The Settled Sorrow of Saddle: The Buryat Ethnic Identity in the Poetry of Bair Dugarov (Dodukova 2019). It was prepared as a result of Alexander Herzen Junior Visiting Fellowship, sponsored by the Institute for Human Sciences and the Mikhail Prokhorov Foundation.
\end{abstract}


Keywords: ethnic identity, revival of historical memory, Buryat poetry, nomad, lineage continuation, ancestor's cult, post-Soviet Buryatia

The Nomad's Star is undoubtedly the most prominent poem of Bair Dugarov (born 1947). First published in 1986 in the collection The Sky, The Nomad's Star then introduced the eponymous collection of poems in 1994. Having appeared in the critical time of post-Soviet searching of self-identification among Buryats, the poem instantly gained popularity and soon was adapted to music by pop singers Saian and Erzhena Zhamablov. Dugarov received the State Award of the Republic of Buryatia in Literature and Art for the book of poems The Nomad's Star in 1995. Such popularity and recognition leave no doubts that the poet not only put in it his intimate thoughts, but also imprinted into it major nationally significant components of the Buryat traditional culture. I argue that the poem The Nomad's Star became the guiding light for an entire generation of Buryats in the critical time of the collapse of the Soviet Union. At this watershed in history, Dugarov called upon his contemporaries to revive the nomadic principles of the ancestors, such as lineage continuation, the ancestors' cult, and harmony in family, which stay relevant and vital at all times. I start with a short overview of Bair Dugarov's biography and the history of the poem. I close read the poem The Nomad's Star and outline the main cultural concepts depicted in it, such as "route," "hearth," "lineage," and others, which promote the idea of the revival of ethnic consciousness in the memory of the Buryats. I support my argumentation by my interview with the poet and literary critics' 
opinions. Finally, the public discourse and social network materials devoted to the poem and the song will evidence the role and significance of The Nomad's Star poem in contemporary Buryatia.

Bair Dugarov began writing poems during his time at school, but his first book of poems, The Golden Saddle, was not published until 1975 (Dugarov 1975). Today, he is officially recognized as a national poet of Buryatia, the author of 15 books of poems. Along with his creative activity, Dugarov has made a career as a scholar - in 2005, he defended his habilitation thesis The Sacral World of the Buryat Geseriade ${ }^{1}$ : Heavenly Pantheon and Genesis of the Hero and obtained the postdoctoral academic degree (doktor filologii). He currently works as an expert researcher of the Department of Literary and Folklore Studies of the Institute of Mongolian, Buddhist and Tibetan Studies of the Russian Academy of Sciences (Siberian Branch). His academic activity could not but influence his poetry, which reflects his deep academic awareness of the history of Mongolian and Buryat tribes, shaman mythology, and archaeological monuments. Appealing to the All-Mongol past has become one of the main topics of Dugarov's poems.

The biography of the poet shows his impact on the revival of ethnic consciousness in Buryatia. As a member and later chairman (1992-1999) of the Union of Writers of Buryatia, he

\footnotetext{
${ }^{1}$ In the mythology of the Mongolian and Tibetan peoples, Geser is a cultural hero - the Son of Heaven. He is the god of war who descended from Heaven to clear the Earth of monsters. The Geseriade is the oral and written epic cycle about Geser, known throughout Central and Eastern Asia. The Buryat versions of the Geseriade are considered the most authentic and can boast up to 50,000 verses.
} 
developed and organized a series of events devoted to returning to Mongolian roots and the revival of historical memory. The poet recalls,

On December 14, 1988, I organized an evening devoted to literary monuments in old-Mongolian. At that time, the political atmosphere was tense everywhere across the USSR, it was the perestroika. Only Buryatia remained the Land of Nod. But that evening in 1988, it seemed the audience let out emotions that had been kept down for years. Even the microphone lit up. Luckily, Vladimir Garmaev, a writer, unplugged it. I was called a troublemaker after that meeting. However, after that evening, lessons of old-Mongolian writing were introduced at the Buryat State University, at schools, in Buriaad Ünen newspaper (Ian 2017).

Another important step towards the revival of ethnic consciousness of the Buryats was the restoration of Sagaalgan [White Month] - the Mongolian Lunar New Year Holiday. In 1989, Bair Dugarov encouraged his colleagues to organize a huge celebration at the Buryat Academic Theater of Drama. Today it is hard to believe that the White Month was officially recognized as a public holiday of the republic only in 1991 . Furthermore, in the 1990s, he initiated a seven-year program of literary and folklore events devoted to the 1,000th anniversary of the Buryat national epos Geseriade. Dugarov reflects,

To a certain extent, the Geseriade has become an embodiment of the growing national consciousness, a return to spiritual roots and sources, a revival of ancient customs and traditions of eternal and universal value. The Geseriade is a kind of hidden reaction to the bitter fruits of historical unconsciousness and national nihilism, which has planted roots in former totalitarian times; and the movement under the sign of Geser - a cultural hero of national level - has thus, to a certain extent, filled in the spiritual and ideological vacuum of the Buryat society in the post-perestroika period (Dugarov 1998, 102). 
The poem The Nomad's Star can be considered as yet another step towards the revival of ethnic identity of the Buryats made by Bair Dugarov. But the poet insists he was not pursuing any ideological objectives when writing this poem:

I do not instruct. I just expressed the sensible subject - it was a splash of my soul... Of course, it is connected to the socio-political processes of that time, but it is wrong to connect it directly, to say that Dugarov wrote this poem when Gorbachev announced perestroika in 1986. It is significanlty deeper and it had been brewing for a long time (Dugarov, personal interview, February 22, 2017).

Indeed, even in his first collections Dugarov develops the topics of nomadism, the Great Steppe, and returning to the historical motherland (e.g. Dugarov 1975). The poet confesses that it was surprisingly easy to commit The Nomad's Star to paper:

Just as Athena leaped from Zeus's head fully grown and armed, this poem was written at once... It seems these lines were maturing for a long time inside of me, and when they were ready, I just wrote them down. Not all verses are born so easily, but this poem was probably destined for it (Dugarov, personal interview, February 22, 2017).

The poem is written in Russian, as the majority of poems by Bair Dugarov. Many people mistakenly think that the poet writes in Russian because he does not speak Buryat. However, his first language was Buryat. He speaks literary Buryat, but what is more, he can understand all the seven dialects of the Buryat language thanks to his experience of living in various regions of Buryatia. Dugarov writes poems in his native language and constantly translates them from Buryat into Russian. The choice of language is one of the most painful issues for 
the Buryat poets of the 20th century (e.g. Baranova 2004); this, however, does not mean that the Buryat identity cannot be expressed in Russian. Bair Dugarov recalls an interesting incident: when he was young and was making his first steps in the field of poetry, he decided to try his luck and went to the Union of Writers of Buryatia: "Once I brought my poems to Isai Kalashnikov. ${ }^{2}$ Dondok Ulzytuev, ${ }^{3}$ a famous Buryat poet who was sitting next to him, looked through my poems and said, The boy writes in Russian, but Buryat is felt" (Ministry of Culture of the Republic of Buryatia 2017).

As mentioned before, the poem was first published in 1986 in the collection of poems The Sky. That same year, it was included into the all-Union collection The Poetry Day. This prestigious annual publication traditionally gathered the best poems from all over the Soviet Union. The collection of 1986 was devoted to poets of Siberia and the Far East. Bair Dugarov recalls,

I was invited to Moscow for a presentation of The Poetry Day. There, in the center of Moscow, standing by the statue of Vladimir Maiakovskii, ${ }^{4}$ I was reciting my poem... One of the poets, his name I cannot remember, who was sitting next to me, told me, Listen, Bair, your poem is sheer aphorisms! And it is really so (Dugarov, personal interview, February 22, 2017).

Indeed, the structure of the poem is very sharp and concise. Each line represents a complete utterance and can be read as

\footnotetext{
${ }^{2}$ Isai Kalashnikov (1931-1980) - Soviet writer, most famous for his historical novel A Cruel Age. Kalashnikov was an executive secretary of the Union of Writers of Buryatia from 1965 until his death in 1980 .

${ }^{3}$ Dondok Ulzytuev (1936-1972) - one of the most prominent Buryat poets writing in Buryat. Some of his poems were translated into Russian by Evgenii Evtushenko.

${ }^{4}$ The statue of Vladimir Maiakovskii was unveiled in 1958 on Maiakovskii Square (currently the Triumphal Square) and soon became the place of various poetry events.
} 
an aphorism. The measured rhythm of iambic pentameter, the repetitive pattern of quatrains, syntactic parallelism - all these features increase the expressiveness of the verse. Such brevity together with the general grand style makes the poem sound as an instruction to the descendants.

\section{Звезда кочевника}

Мужчине - путь, а женщине - очаг. И чтобы род мой древний не зачах, роди - молю и заклинаю - сына. Стрела летит, покуда жив мужчина.

Мужчине - дым, а женщине - огонь. И чтоб в бою мой не споткнулся конь, я должен знать, что юрту греет пламя, как предками завещанное знамя.

\section{The Nomad's Star}

The route is to man as the hearth is to woman.

And so that my ancient lineage does not wither away,

I pray and entreat - give birth to a son.

The arrow flies as long as the man lives.

Smoke is to man as fire is to woman.

And so that my steed does not stumble in battle,

I must know that the yurt is heated by the flame,

Like the battle standard left after my forefathers.

In man lies the spirit, in woman - the soul.

The trembling blade of grass holds the sky. Without a hearth, without a son, without my beloved,

I am scattered above the plain, like a solitary sandstorm. ${ }^{5}$

When analyzing the poem, the first thing that catches the eye is the structural similarity of the first lines of each quatrain. The structural repetitions and instructive tone embody a philosophical paradigm: "The route is to man as the hearth is to

${ }^{5}$ All translations of quotations from the Russian, Mongol and Buryat languages are mine, unless otherwise indicated - G. D. 


\section{Galina Dondukova}

woman," "Smoke is to man as fire is to woman," "In man lies the spirit, in woman - the soul." At first sight, it seems the poet makes a clear distinction between the gender duties of men and women: a man is connected with his horse, he rides through the steppe, hunts and fights, while a woman should sit at home and maintain the hearth. One might think that the poet affirms the patriarchal lifestyle of nomads. However, he actually reveals here one of the main principles of Buryat cosmology: even though they are opposite, male and female forces are always interconnected and form a unity.

This male-female relationship was expressed among the Mongolian peoples by the notion of arga-bilig. According to 286 Lidiia Skorodumova, the arga-bilig doctrine is a component of Mongolian astrology (zurkhai), whose basic framework was formulated in Tibet and became widespread in Mongolia together with Tibetan Buddhism in the 16-17th centuries (Skorodumova 1994). However, Mongolian researcher Dondogzhalyn MönkhOchir, author of a series of publications about arga-bilig, defines this doctrine as a pure Mongolian "invention" that arose gradually from observations of nature made by ancient nomads (Mönkh-Ochir 1993, 6). Arga-bilig, a term which can be translated as "mode" and "wisdom," is composed of two words, expressing two opposite categories, including the opposition of man and woman, sky and earth, sun and moon, night and day, summer and winter, hot and cold, up and down. The main idea of arga-bilig is that harmony in the world lies in the interaction of two opposite principles. Mongolists insist that the arga-bilig principle is not similar to European dialectics, 
as it concentrates not on the clash but on the unity of the two opposites (Buren-Ulzii 2010). What is more, the world cannot exist beyond this principle in the same manner as there cannot be night without day and vice versa. From the point of view of this doctrine, all interrelations in the world are established and systematized according to the principle of arga-bilig.

Arga determines the external, while bilig - the internal influence of the phenomenon, and as a result they form a complete system of the universe. The scheme of the relationship between arga and bilig is as follows: bilig constantly exists and develops in arga, while arga, being a form or mode, protects bilig, thus, there is always bilig in arga, and vice versa (Belokurova 2011, 116-7).

In such a way, Dugarov prescribes a deep philosophical meaning in The Nomad's Star: the harmony of the world lies in the inseparability and complementariness of two opposite components. Men have their own duties, women - their own, but one cannot exist without the other, and only together can they achieve harmony. The poetic lines acquire an instructive meaning as the poet declares principles of the nomad life of the ancestors, which become actual and vital for his contemporaries.

The lines "The route is to man as the hearth is to woman" and "Smoke is to man as fire is to woman" are very similar. The idea of the route, motion around the steppe is connected with smoke. As Dugarov says, this reflects the philosophy of nomads: smoke spreads in space, just as a nomad does while moving about the space of the steppe. "It is a subtle metaphor" (Dugarov, personal interview, February 22, 2017). In other words, both notions, route and smoke, express the idea of 
movement, dynamics. As for the cult of hearth and fire, they are undoubtedly synonymous in the traditional Buryat world perception and refer to the female.

Archeological finds - female figurines - discovered in close proximity to home-fires and ethnographic material witness that home-fire worship was the responsibility of women for the majority of peoples of Siberia. This finding is also reflected in the term udagan (odigon), which derives from the Turkic word ot or $u t$ meaning fire, and has the all-Mongolian female name ending gan. Udagan, known among both Turkic and Mongolian peoples, usually refers to the female shaman. However, initially the term udagan probably designated priestesses of fire. Over time, with the loss of functions of the priestess of fire, this word began to mean a female shaman (Galdanova 1987, 24-5).

In the traditional Buryat yurt, the hearth occupied the central position and appeared as its crucial part. According to Marina Sodnompilova, the organization of a yurt represents the interpretation of the world structure among the Mongols. The floor of the yurt designates the Earth, the oval roof acts as the Sky, and the hearth located in the center of yurt is the place of Fire. "To the Mongolian people, the vertical axis of the hearth, toono, reflects the idea of the triplicity of the world: the hearth's fire reaches the Sky, smoke permeates the 99 heavenly layers (or covers them), heat penetrates through the Earth and warms her 77 layers" (Sodnompilova 2009, 315). Thus, the fire, or hearth, in a yurt plays a crucial role for Mongols, as it embodies one of the three main elements.

Dugarov continues to develop the concepts of fire and hearth in the lines "I must know that the yurt is heated by the flame, / Like the battle standard left after my forefathers" by appealing 
to the connection of the fire cult with the cult of ancestors in the Buryat traditional culture. Indeed, the Buryat fire cult used to fulfill functions associated with the lineage: the vital forces of the family - sülde - were believed to live in the hearth (Babkinova $2009,21)$. That is why there exists a number of taboos connected with the hearth and fire. The main idea behind them is not to profane the hearth, as it can lead to disintegration of the family and even fading of the lineage. Thus, it was forbidden to pour water on fire or to touch fire with a knife or any other sharp object. It was also prohibited to throw garbage or dirt into fire and to extinguish fire in the hearth (Galsanova 2012, 156).

It is necessary to take a closer look on the concept of sülde in the Mongolian culture. Caroline Humphrey and Hürelbaatar Ujeed write that the Mongolian word sülde can be translated as might, life force, inspiration. "Sülde can refer to a personal entity like a 'soul' and to the spirit of an ancestor" (Humphrey and Ujeed 2012, 155). What is more peculiar, sülde can be located not only within the human, but "outside oneself, taking residence in a deity or in particular objects, such as battle standards (tug, sülde), flags, and state or military emblems" (Humphrey and Ujeed 2012, 154). Zoia Morokhoeva writes that in the military art, sülde receives the meaning of spiritual power of the people or army. For example, sülde is the keeper of Genghis Khan's lineage that lived in his nine-legged white battle standard; this sülde saved his troops, leading them to victories and conquest of all countries (Morokhoeva 2013, 68). In other words, sülde can be translated from the Buryat not only as soul but also as battle standard (which contains soul). 
Thus, Dugarov implements a series of interconnected concepts: fire - hearth - battle standard, which all are related to the cult of ancestors, and the life forces of the family. The concentration of value-laden keywords in a few lines is immense. According to Dugarov, he did this on an intuitive level,

because I am Buryat myself, I feel all this. And poets actually write it in this way: they do not comprehend, do not allude to something on purpose. It all should be expressed naturally. A poet writes on an intuitive level, otherwise it is not poetry (Dugarov, personal interview, February 22, 2017).

Nevertheless, even unconsciously, Dugarov shows great competence in condensing the traditional knowledge concerning the Buryat culture. The Nomad's Star, unintentionally but surely, instructs the contemporaries: the spirit of lineage, of the nation should not be forgotten, but ought to be transmitted through generations as the battle standard or an inextinguishable flame.

The motif of lineage becomes the major concept. Its another aspect - patrilineal continuation of lineage - is represented in the first quatrain "I pray and entreat - give birth to a son / The arrow flies as long as the man lives." The image of an arrow becomes associated with the male principle, which is typical of Buryat traditional culture, where an arrow represents the power of a man. The symbol of a bow with an arrow goes back to ancient hunting rituals: when the man learns to use the bow, he can become a full member of society, continue his lineage, and start a family. The idea of an arrow as a symbol of manhood and power of lineage is mentioned in Buryat shamanic songs. Dampilova writes that if a baby boy survived the first two years of his life, shamans sang a song of praise. The abovementioned lines of Dugarov's 
poem repeat an extract from this song almost word for word. The poem can be perceived as a shamanic incantation due to its structural similarity and semantic proximity to the shamanic song:

Эбэр, эбэр татаха

Отогохон номомни.

Элэн, элэн харбаха

Зартагайхан годолимни...

Тэбэдэн үгэн харбуулха

Минии нэрэ байналдаа

(Dampilova 2012, 92).
Firmly, firmly the bow of my lineage will tighten.

Wearing off, wearing off, an arrow

Shoots from the rushlight...

It will always shoot,

And continue my name

It is necessary to mention that the pressure that is imposed on the son as the continuator of a lineage can be connected with the personal drama of the poet. Bair Dugarov himself does not have a son but two daughters, who were born in 1982 and 1983. The Nomad's Star was first published in 1986, and probably the poet captured his emotions from that time in the poem. His younger daughter writes in her recent book The Star of a Nomadess, "When I was born, my father could not hide his disappointment... so strong was his desire to have a continuator of the Dugarov lineage" (Dugarova 2017, 1).

Lastly, the motif of lineage is most convincingly expressed in the closing lines of the poem: "Without a hearth, without a son, without my beloved, / I am scattered above the plain, like a solitary sandstorm." The poet sums up all the previous images which embody lineage for him: the hearth, the son, the beloved. The hearth, the fire, links the lyrical subject with his ancestors; the son and the arrow spell the future of his lineage. The nomad's route as one of the major concepts of 
Dugarov's poetry is transformed here into the route of the lineage. His ancient lineage will not break off and his name will not disappear as long as the flame heats the yurt, as long as "the arrow flies."

The lineage motif plays a central role in the poem yet is not the only one. The line "The trembling blade of grass holds the sky" explains another aspect of the nomad's philosophy: the global depends on the smallest; the universe is one whole: in the chain of seasons and life cycles, people, animals, mountains are interdependent, and even a tiny blade of grass can make a difference and "hold the sky." Dugarov defines this line as concluding, "Here is all the philosophy. This delicate 292 line contains everything in it" (Dugarov, personal interview, February 22, 2017). This poetic reflection has become an independent aphorism among the Buryats. For example, in social networks, on Facebook or Instagram, it is possible to find posts citing the known line from Dugarov's poem (e.g. Shiribon 2017). Thus, a Buryat ethno-pop singer Medegma Dorzhieva (born 1980), bearer of the title Honored Artist of the Republic of Buryatia, on January 22, 2017, posted a close-up photo of a frosted blade of grass with a clear blue sky in the background and captioned it: "\#winter \#belovedburyatia \#healthylifestyle ...The trembling blade of grass holds the sky" (Dorzhieva 2017). The fact that she did not cite the name of the poet means that she presupposed that her followers were acquainted with the work of Dugarov, and thus confirms the popularity of not only the poem The Nomad's Star, but even specific lines of the poem.

Finally, it is necessary to analyze the very title of the 
poem - The Nomad's Star. Marina Sodnompilova writes that celestial orientation based on the most perceptible stars and constellations of the northern hemisphere was common among the nomads due to their hunting and gathering way of life. The most known celestial bodies include Planet Venus (Solbon), esteemed as the patron of horses, and the Great Bear (Ursa Major) constellation, which is mentioned in many myths and legends, especially those concerning the creation of the world (Sodnompilova 2009, 216). Dugarov expresses the traditional guiding role of stars in his other poems: "Fly, o rider, never / will the Destiny stop your run / There is smoke of camp fires on the Earth / and a bright star in the sky" (Dugarov 1994, 178). It is this idea of a star as the reference point that is developed in The Nomad's Star, where it becomes a guiding light for the modern generation of Buryats.

When speaking about the poem of Bair Dugarov and its impact on the Buryat national development, it is important to analyze the song The Nomad's Star written by Saian and Erzhena Zhambalov. Saian and Erzhena are one of the most famous artistic couples of contemporary Buryatia. They started their career at the Buryat Academic Theater of Drama in the 1990s, and today Saian is a stage director there, while Erzhena is a director of the Buryat State Academic Opera and Ballet Theater. But apart from their theatrical activity, they are widely known as pioneers of the Buryat pop music genre. Since the 1990s, they have been writing music and lyrics and singing as a duet. The Nomad's Star became their hit song and played a big role in the popularization of Dugarov's poem not only in Buryatia but also far beyond its borders. The idea to adapt the 
lines to music occurred to Saian in 1996, when the delegation of artists from Buryatia arrived in Moscow for the festival of Buryat culture and art. Erzhena recalls,

after two days of performing our own songs in Buryat, Saian proposed, "Listen, we are singing in Buryat here, but who understands us? There is a great poem by Bair Dugarov - The Nomad's Star. Let's write a song, because the Muscovites should hear about the beauty of our nation in a language they understand." So we wrote the music overnight, and the next day, in the afternoon, we already stood on the stage in the middle of the All-Union Exhibition of Achievements of the National Economy and sang that song. Muscovites walked up later and thanked us (Tsybdenova 2017).

Hence, thanks to the fact that the song was in Russian, it became accessible to a wider audience in comparison to other Buryat songs of the Zhambalovs. The philosophical meaning of the poem struck many Russians, as well as people of other nationalities, for example, the Kalmyks or the Tuvinians. To some extent, the song has become even more popular than the initial poem. Thus, searching the Russian Google for "the nomad's star Erzhena and Saian Zhambalov" renders 3,200 results (Google 2018a); however, if you search for "the nomad's star Bair Dugarov," you will get only 2,360 results (Google 2018b).

But above all, the song gained popularity among the Buryats themselves. One of the proofs of the public recognition is the award for Buryatia's "Best Song of the Century" in the category "amateur composer," which was presented to the songwriters at the turn of the 20th century (Uragsha n.d.). The artists continued collaborating with the poet throughout the years. In 2012, they staged a new project - the musical performance Sutra of 
Moments - where the poems of Bair Dugarov were adapted to music and combined with a choreographic performance. They also released the album I Am Perhaps the Last Buryat-Mongol, where the poems of Bair Dugarov were yet again adapted to music. In 2016, the Zhambalovs celebrated 30 years of their artistic career and organized an anniversary concert entitled In Man Lies the Spirit, in Woman - the Soul. The line from The Nomad's Star chosen as the name of the concert underlines the combination of male and female forces in their duet, additionally, it clearly shows that The Nomad's Star has become the main song showcasing their work. Indeed, a local news portal claims, "Perhaps there is not a single person in Buryatia who did not hear The Nomad's Star song performed by Saian and Erzhena Zhambalov" (Bez Formata 2012). For the Buryats, the song turned into a new symbol of traditional culture and family values. Maybe precisely because of the ideas of lineage continuation, the ancestors' cult, and male-female harmony in the family, The Nomad's Star is a song usually performed during Buryat weddings. The moment of creation of a new family is accompanied by the song that most vividly expressess the traditional Buryat family model.

The Nomad's Star developed into an independent brand. For one, it is a popular name for various ethnic places. For example, there is The Nomad's Star restaurant in Chita, Zabaikal'skii Krai. According to its webpage, it is a restaurant of primarily Buryat-Mongol, but also European and Chinese cuisine. It claims that the main difference between The Nomad's Star and other restaurants lies not only in delicious dishes but also the 
atmosphere of national culture and traditions. The sandy color of the interior symbolizes the steppe, while the huge dome made of blue glass represents "the clear sky over the head of nomads" (Zvezda kochevnika n.d.). It is remarkable that the official webpage of the restaurant does not make any reference to the poem of Bair Dugarov, but in the restaurant's group on the social network Vkontakte one can find the song by Saian and Erzhena Zhambalov. This fact demonstrates that the phrase The Nomad's Star became identifiable thanks to the song of the Zhambalovs. And as an identifiable brand, it started to be used by Buryat entrepreneurs. Another place called The Nomad's Star is a guest house on Olkhon Island, Irkutsk Oblast. Olkhon is the 296 largest island on Lake Baikal and with its diverse landscapes and untouched natural monuments is deservedly regarded as one of the most beautiful places on Baikal. Besides, the island is considered one of the most powerful spiritual places by Buryat shamans. It is not a surprise that this place is highly popular among tourists. According to the official webpage of the guest house, it too puts a focus on ethnicity: "a combination of Buryat culture, Buryat hospitality and sacrality of the Olkhon Island" (Baza otdykha Zvezda kochevnika n.d.). In Ulan-Ude, the capital of the Republic of Buryatia, there is also a souvenir shop named The Nomad's Star. The shop is one of the pioneers in the souvenir industry in Buryatia, which saw rapid development in the 2000s. It first sold finished goods made of leather and wool in Mongolia. Nowadays, the shop has ventured out and has its own production, with two big souvenir stores in the city center and an online-shop. Just as in case of the Chita restaurant, both the 
guest house and the souvenir shop do not refer to the poem of Bair Dugarov and they do not need to, because the name The Nomad's Star is truly recognizable. Its recognizability together with reference to traditional Buryat nomadic culture made it a popular name for various ethnic places throughout East Siberia, from Irkutsk to Chita, where the idea of nomadism is one of the main tourist highlights.

Returning to the poem of Bair Dugarov, it can be said that The Nomad's Star is his best poetic work. In this regard, the evening with Bair Dugarov devoted to his 70th anniversary, which was held on December 14, 2017, at the Buryat Academic Theater of Drama in Ulan-Ude, was very emblematic. The show can be considered as a kind of compilation of all the creative routes taken by the poet. All seats were booked. The reading of his favorite poems was accompanied by a concert. The Buryat State National Song and Dance Theatre "Baikal" presented several excerpts from the music and choreographic performance about the legendary ancestral homeland of the Buryats Echo of Country Bargudzhin-Tukum, whose libretto was written by Dugarov. The opera singers performed romances based on his poems, while the artists from the Buryat Drama Theatre staged several crucial moments from the family life of the poet. But the performance of The Nomad's Star by Saian and Erzhena Zhambalov became the pinnacle of the whole concert. "Of course, it would not be complete without the dear and legendary song The Nomad's Star based on the verses of the poet," reported the local newspaper (Tsybdenova 2017). 
To conclude, the close reading of The Nomad's Star poem revealed its main nationally significant concepts, which have been broadly promoted by Bair Dugarov throughout his public activity since the 1990s. The poem has become not just his most popular work but also "a kind of a symbol of Buryat consciousness" (Dugarova 2017, 1). The song written by Saian and Erzhena Zhambalov contributed to the popularization of the nomadic sentiments and encouraged a revival of ethnic identity roots among the Buryats, initiated by the poet. And thus, The Nomad's Star of Bair Dugarov has truly turned into a guiding light for the modern generation of Buryats.

\section{WORKS CITED}

Babkinova, Lidiia V. 2009. Mifopoetika sovremennoi buriatskoi poezii [Mythopoetics of modern Buryat poetry]. Irkutsk: Izdatel'stvo Irkutskogo gosudarstvennogo universiteta.

Baranova, Olesia Iu. 2004. "Russko-buriatskoe literaturnoe pogranich'e: Teoreticheskii i esteticheskii aspekty" [Russian-Buryat literary borderland: Theoretic and aesthetic aspects]. PhD diss., Buriatskii gosudarstvennyi universitet, Ulan-Ude.

Baza otdykha Zvezda kochevnika. n.d. "Baza otdykha 'Zvezda Kochevnika", [The Nomad's Star Leisure Center]. Accessed February 20, 2018. http://zvezdakochevnika.ru/

Belokurova, Sofiia M. 2011. "Potentsial filosofskogo ucheniia arga bilig pri issledovanii kul'turnykh konstant" [Potential of the arga bilig philosophical doctrine in the research of cultural constants]. Vestnik Novosibirskogo gosudarstvennogo universiteta: Seriia Filosofiia 9 (1): 115-9.

Bez Formata. 2012. "Na stikhi poeta Baira Dugarova postavili spektakl' 'Sutra mgnovenii"” [The poems of Bair Dugarov were staged as "The Sutra of Moments"]. Bez Formata website. Accessed February 20, 2018. http://ulanude.bezformata.ru/ listnews/postavili-spektakl-sutra-mgnovenij/4307945/

Buren-Ulzii, Idree. 2010. "Ideia sistemnosti v poslovitsakh i pogovorkakh" [The idea of systematicity in proverbs]. Vestnik AltGTU im. I. I. Polzunova 1-2: 108-11.

Dampilova, Liudmila S. 2012. Shamanskiepesnopeniia buriat: Poetika isimvolika [Shamanic songs of the Buryats: Poetics and symbolism]. Moskva: Vostochnaia literatura. 


\section{THE NOMAD'S STAR OF BAIR DUGAROV AS THE GUIDING...}

Dondukova, Galina. 2019. The Settled Sorrow of Saddle: The Buryat Ethnic Identity in the Poetry of Bair Dugarov. PhD diss., University of Warsaw.

Dorzhieva, Medegma [@midigmadorzhieva]. 2017. “\#zima \#liubimaiaburiatiia \#zozh 'Travinka derzhit nebo trepeshcha"” [\#winter \#belovedburyatia \#healthylifestyle "The trembling blade of grass holds the sky"]. Instagram website, January 22. Accessed January 22, 2017. https://www.instagram.com/p/BPj3sARh3qd/?takenby=midigmadorzhieva

Dugarov, Bair S. 1975. Zolotoe sedlo [The golden saddle]. Irkutsk: Vostochno-sibirskoe knizhnoe izdatel'stvo.

Dugarov, Bair S. 1986. Nebosklon [The horizon]. Ulan-Ude: Buriatskoe knizhnoe izdatel'stvo.

Dugarov, Bair S. 1994. Zvezda kochevnika [The nomad's star]. Irkutsk: Vostochnosibirskoe knizhnoe izdatel'stvo.

Dugarov, Bair S. 1998. "Geseriada kak etnokul'turnyi faktor v sovremennykh usloviiakh" [Geseriade as ethno-cultural factor in modern conditions]. In Traditsionnyi fol'klor v polietnicheskikh stranakh: Materialy II Mezhdunarodnogo nauchnogo simpoziuma “Baikal'skie vstrechi," edited by R. I. Pshenichnikova, 99-103. Ulan-Ude: VSGAKI.

Dugarova, Esuna B. 2017. Zvezda kochevnitsy: V garmonii mezhdu vostokom i zapadom [The star of a nomadess: In harmony between the East and the West]. SanktPeterburg: Art-Ekspress.

Galdanova, Galina R. 1987. Dolamaistskie verovaniia buriat [Pre-Lamaist belief system of the Buryats]. Novosibirsk: Izdatel'stvo "Nauka," Sibirskoe otdelenie.

Galsanova, Ol'ga E. 2012. "Nekotorye arkhetipicheskie obrazy v traditsionnoi kul'ture buryat" [Some archetypical images in the traditional culture of the Buryat people]. Vestnik Buriatskogo gosudarstvennogo universiteta 12: 154-9.

Google. 2018a. "zvezda kochevnika Erzhena i Saian Zhambalovy" [nomad's star Erzhena and Saian Zhambalov]. Google website. Accessed February 20, 2018. https:/www.google.ru/search?newwindow=1\&source=hp\&ei=EKiOWsnQI8HQk wWvzY64CA\&q=звезда+кочевника+эржена + и+саян+жамбаловы\&оq=звезда +кочевника+эржена+и+саян+жамбаловы\&gs_l=psy-ab.3..35i39k112.671.8055. $0.8390 .23 .21 .0 .0 .0 .0 .234 .2459 .5 \mathrm{j} 14 \mathrm{j} 1.20 .0 \ldots .0 \ldots 1 \mathrm{c} .1 .64 . p s y-a b . .4 .17 .2091 .0 . .0 \mathrm{j} 46 \mathrm{j}$ 0i46k1j0i203k1j0i46i203k1j46i203k1.0.RApWkfyUO6M

Google. 2018b. “zvezda kochevnika Bair Dugarov" [nomad's star Bair Dugarov]. Google website. Accessed February 20, 2018. https://www.google.ru/search?newwindow=1 \&ei=1aiOWt7IOJCukwXU-YLwDQ\&q=звезда+кочевника+баир+дугаров\&oq=3 везда+кочевника+баир+дугаров\&gs_l=psy-ab.3..35i39k1.3403.5570.0.5998.11.8. 3.0.0.0.179.756.6j2.8.0...0...1c.1.64.psy-ab..1.5.347...0i7i30i19k1.0.qaIQPuHWFw0

Humphrey, Caroline, and Hurelbaatar Ujeed. 2012. "Fortune in the Wind: An Impersonal Subjectivity.” Social Analysis 56 (2): 152-67.

Ian, Andrei. 2017. "Bair Dugarov: 'Ia syn Pobedy"” [Bair Dugarov: "I am the son of victory"]. Inform Polis website, December 13. Accessed December 3, 2017. https:// www.infpol.ru/news/leisure/137815-bair-dugarov-ya-syn-pobedy/

Ministry of Culture of the Republic of Buryatia. 2017. "Bair Dugarov: 'Cheloveku nuzhno popast' v sredu sebe podobnykh"” [Bair Dugarov: "A man needs to find 


\section{Galina Dondukova}

a milieu of people like him"]. Accessed March 1, 2018. http://minkultrb.ru/news/ detail.php?SECTION_ID=95\&ELEMENT_ID=16093

Mönkh-Ochir, Dondogzhalyn. 1993. Mongol zurkhain tuukhen ulamzhlal [Mongolian traditions of astrology]. Ulaanbaatar: Urlakh erdem khevleliin gazar.

Morokhoeva, Zoia. 2013. Dialog kul'tur Vostoka i Zapada v epokhu globalizatsii: Perspektiva Evro-Azii [Dialogue of cultures of the East and the West in the epoch of globalization: An Euro-Asian perspective]. Varshava, Kiev: Takson.

Shiribon, Elena. 2017. "Travinka derzhit nebo trepeshcha" [The trembling blade of grass holds the sky]. Facebook photo, July 27. Accessed July 27, 2017. https:// www.facebook.com/photo.php?fbid=1460198057380376\&set=pcb.14601981307 $13702 \&$ type $=3 \&$ theater

Skorodumova, Lidiia G. 1994. Buddiiskaia astrologiia [Buddhist astrology]. Abkhidkharma Tsoi website. Accessed February 28, 2018. http://abhidharma. $\mathrm{ru} / \mathrm{A} /$ Samsara/Content/0002.pdf

Sodnompilova, Marina M. 2009. Mir v traditsionnom mirovozzrenii i prakticheskoi deiatel'nosti mongol'skikh narodov [The world in traditional worldview and practices of Mongolian peoples]. Ulan-Ude: Izdatel'stvo BNTs SO RAN.

Tsybdenova, Oksana. 2017. "Vecher poezii Baira Dugarova v Ulan-Ude proshel pri anshlage" [Bair Dugarov's poetry evening in Ulan-Ude was a full house]. Buriaad Ünen newspaper, December 22. Accessed December 22, 2017. https://burunen.ru/ site/news?id=20689

Uragsha. n.d. "Zhambalova Erzhena Zugdarovna." Accessed February 20, 2018. http:// www.uragsha.ru/index 73c2.php?option=com_content\&view $=$ article\&id $=9: 2010$ 12-21-07-19-26\&catid=3:2010-11-10-06-39-20\&Itemid=11

Zvezda kochevnika. n.d. 'Zvezda kochevnika - restoran buryat-mongol'skoi, evropeiskoi i kitaiskoi kukhni" [The Nomad's Star - restaurant of Buryat-Mongolian, European and Chinese cuisine]. Accessed February 20, 2018. http://zvezdakochevnika.chita.ru/ 


\section{ABOUT THE AUTHORS}

Darima Amogolonova - doctor of sciences in history, associate professor and leading researcher at the Department of Philosophy, Cultural Anthropology and Religions at the Institute for Mongolian, Buddhist and Tibet Studies, Siberian Branch of the Russian Academy of Sciences, Ulan-Ude, Russian Federation. E-mail: amog@inbox.ru

Nikolai Baikalov - candidate of sciences (PhD) in history, associate professor at the Buryatia History Department, Buryat State University, Ulan-Ude, Russian Federation. E-mail: baikalchik@yandex.ru, baikalov@bsu.ru

Darima Bajko - ecologist, independent researcher of ecological and social issues of the Baikal region. E-mail: vinda91@inbox.ru

Daria Burnasheva - $\mathrm{PhD}$ in cultural sciences, senior lecturer at the Arctic State Institute of Culture and Arts, Yakutsk, Russian Federation. E-mail: daria.burnasheva@gmail.com

Bato Dondukov - PhD in cultural studies, senior researcher at the Department of Organization and Management of Scientific 


\section{ABOUT THE AUTHORS}

Researches at the East-Siberia State University of Technology and Management, Ulan-Ude, Russian Federation. E-mail: dondukovb@gmail.com

Galina Dondukova - $\mathrm{PhD}$ in literary studies, senior researcher at the Department of Organization and Management of Scientific Researches at the East-Siberia State University of Technology and Management, Ulan-Ude, Russia. E-mail: galina.dondukova11@gmail.com

Jan Kieniewicz - historian and diplomat, full professor at the Faculty of "Artes Liberales," University of Warsaw, Poland. E-mail: jotka@al.uw.edu.pl

Bair Nanzatov - candidate of sciences (PhD) in history, senior researcher at the Department of History, Ethnology and Sociology, Institute for Mongolian, Buddhist and Tibetan Studies, Siberian Branch of the Russian Academy of Sciences, Ulan-Ude, Russian Federation. E-mail: nanzatov@yandex.ru

Marina Sodnompilova - doctor of sciences in history, leading researcher at the Department of History, Ethnology and Sociology, Institute for Mongolian, Buddhist and Tibetan Studies, Siberian Branch of the Russian Academy of Sciences, UlanUde, Russian Federation. E-mail: sodnompilova@yandex.ru

Zbigniew Szmyt - PhD in in ethnology and cultural anthropology, assistant professor at the Institute of Ethnology and 
Cultural Anthropology, Adam Mickiewicz University, Poznań, Poland. E-mail: szmytz@amu.edu.pl

Kamil M. Wielecki-PhD in ethnology and cultural anthropology, assistant professor at the Faculty of "Artes Liberales," University of Warsaw, Poland. E-mail: kamil.wielecki@al.uw.edu.pl

Ayur Zhanaev - PhD in sociology, assistant professor at the Department of Culturally Integrated Legal and Social Studies, Institute of Social Prevention and Resocialization, University of Warsaw, Poland. E-mail: a.zhanaev@uw.edu.pl 


\section{LIBALMONOGRAPHS}

The volume discusses the dynamically changing identities among Buryats and other nations of Eastern Siberia and Inner Asia. The wide range of articles has been organized into three clusters - Ethnicity and Nation-Building Processes, Buddhist Identities, and Landscape and Indigenization. Some of the papers present anthropological empirical research of particular groups, while other adopt a perspective of literary or ecological, studies. Constituting an interdisciplinary endeavor, the volume tries thus to link the diverse phenomena under investigation and different research methodologies, and to show them in a wider context of historical and transnational processes. Lastly, it aims at bringing new theoretical perspectives to studies of nations and peoples of broadly understood Inner Asia.

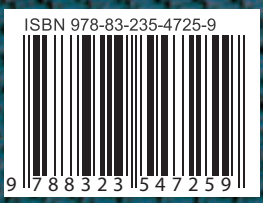

